UNIVERSIDADE DE SÃO PAULO

FACULDADE DE FILOSOFIA, CIÊNCIAS E LETRAS DE RIBEIRÃO PRETO

PROGRAMA DE PÓS-GRADUAÇÃO EM PSICOLOGIA DOUTORADO EM PSICOLOGIA

JULIENE MADUREIRA FERREIRA

Crianças com déficit intelectual e processos interacionais com pares na préescola: reflexões sobre desenvolvimento

Ribeirão Preto

Maio de 2017 
JULIENE MADUREIRA FERREIRA

\title{
Crianças com déficit intelectual e processos interacionais com pares na pré-escola: reflexões sobre desenvolvimento
}

\author{
Tese apresentada ao Programa de Pós-Graduação em \\ Psicologia da Faculdade de Filosofia, Ciências e \\ Letras da Universidade Federal de São Paulo, como \\ requisito para a aquisição do título de Doutor em \\ Ciências. \\ Área de concentração: Psicologia em Saúde e \\ Desenvolvimento
}

Orientadora: Profa. Dra. Katia de Souza Amorim

Ribeirão Preto

Maio de 2017 
Autorizo a reprodução e divulgação parcial ou total deste trabalho, por qualquer meio convencional ou eletrônico, para fins de estudo e pesquisa, desde que citada a fonte:

Catalogação na Publicação

Serviço de Biblioteca e Documentação

Universidade de São Paulo

Ferreira, Juliene Madureira

Crianças com déficit intelectual e processos interacionais com pares na préescola: reflexões sobre desenvolvimento / Juliene Madureira Ferreira; Orientadora Kátia de Souza Amorim, Ribeirão Preto, 2017.

$258 \mathrm{f}$.

Tese (Doutorado) - Faculdade de Filosofia, Ciências e Letras da Universidade de São Paulo. Programa de Pós-Graduação em Psicologia. Área de concentração: Psicologia em Saúde e Desenvolvimento.

1. Interação de pares. 2. Desenvolvimento Humano. 3. Déficit Intelectual. 4. Educação Infantil 
Nome: Juliene Madureira Ferreira

Título: Crianças com déficit intelectual e processos interacionais com pares na pré-escola: reflexões sobre desenvolvimento.

Tese apresentada ao Programa de Pós-Graduação em Psicologia, da Faculdade de Filosofia, Ciências e Letras da Universidade Federal de São Paulo, como requisito para a aquisição do título de Doutor em Ciências.

\section{Aprovado em 3 de maio de 2017}

Presidente da Banca Examinadora e orientadora

Profa. Livre Docente Kátia de Souza Amorim

Universidade de São Paulo, Ribeirão Preto

Membros Titulares da Banca

Profa. Dra. Niina Rutanen

Universidade de Jyväskylä, Finlândia

Profa. Dra. Rosângela Gavioli Pietro

Universidade de São Paulo, São Paulo

Profa. Dra. Claudia Dechichi

Universidade Federal de Uberlândia, Minas Gerais

Profa. Livre Docente Zilma Moraes R. Oliveira

Universidade de São Paulo, São Paulo 
Aos meus companheiros da profissão docente, da Escola de Educação Básica da Universidade Federal de Uberlândia, cujos trabalhos me inspiraram a iniciar esse processo investigativo.

À Inácio, Ivan e Amanda.

À população brasileira, que tem financiado meus estudos desde a graduação. 


\section{Meus mais sinceros agradecimentos}

À professora Kátia de Souza Amorim, pela calorosa acolhida e atenta orientação durante todo o percurso de construção desse trabalho, sempre disposta a dialogar, construir, desconstruir e reconstruir caminhos.

Às professoras Ana Luiza B. Smolka, Zilma de Moraes R. Oliveira e Claudia Dechichi, pelas ricas contribuições na banca de qualificação.

Aos amigos queridos Gabriela Moura, Ludmilla Dell’Isola, Pedro P. Martins e Gabriela Martins, pelas trocas que foram fundamentais para a minha existência, ao longo desse percurso.

Aos meus colegas da Escola de Educação Básica da UFU, que me apoiaram nessa caminhada, pela possibilidade que meus passos ultrapassassem os muros da nossa escola.

Aos meus colegas do Centro de Investigações sobre Desenvolvimento Humano e Educação Infantil-USP, pelas diferentes e importantes interlocuções que ampliaram meu olhar investigativo.

Aos meus familiares e aos muitos amigos queridos, cujos nomes não são aqui mencionados, mas que ficarão eternamente marcados no meu coração, obrigada por estarem ao meu lado nas adversidades da vida, nos contratempos que marcaram minha história durante esse percurso.

À Capes, pelo reconhecimento da relevância da pesquisa e apoio financeiro durante o estágio interinstitucional internacional na Universidade de Tampere, Finlândia.

My thank you also to Marita Mäkinen, Kirsti Karila and all dear colleagues from the University of Tampere, for the opportunity for such intense and rich learning process.

Tahalle, joka toi rauhan sydämeeni. 
Uma tese não é o final de nada, é apenas o começo de uma caminhada...

(Prof. Fernando González Rey) 


\section{Resumo}

Ferreira, M. F. (2017). Crianças com déficit intelectual e processos interacionais com pares na préescola: reflexões sobre desenvolvimento. Tese de doutorado, Faculdade de Filosofia, Ciências e Letras, Universidade de São Paulo, Ribeirão Preto.

A presente tese de doutorado tangencia a temática da Inclusão Escolar a partir da análise dos processos de interação de pares em contexto de Educação Infantil. Dentro desse complexo e amplo fenômeno, o foco do processo investigativo recaiu sobre as possibilidades de desenvolvimento da criança com déficit intelectual, discutindo, a partir da perspectiva Histórico-Cultural, o conceito teórico da Zona de Desenvolvimento Proximal de Lev S. Vygotsky. A partir desse recorte, buscou-se apreender os processos interativos de crianças com e sem déficit intelectual no contexto institucional escolar, analisar como as relações estabelecidas entre pares são construídas e, nessa construção, como possibilitam a transformação das habilidades potenciais em habilidades reais, em diferentes atividades. O objetivo específico foi identificar se existiam indícios empíricos que sustentariam a discussão conceitual de que o impacto das regulações e corregulações de comportamento por pares de idade também poderia ser considerado elemento que cria Zonas de Desenvolvimento Proximal às crianças com déficit intelectual. Para tanto, optou-se por desenvolver um processo investigativo de base epistemológica qualitativa, a partir das contribuições teóricas provenientes da Rede de Significações, por meio de três diferentes recursos de coleta de dados: o vídeo registro, as entrevistas semiestruturadas e o diário de campo. Os participantes da pesquisa foram três crianças pivôs diagnosticadas como tendo déficit intelectual, de idade entre três anos e meio e cinco anos, de duas Instituições de Educação Infantil. Para além, foram considerados participantes os familiares das três crianças, seus respectivos professores e as demais crianças que compartilhavam o contexto institucional. A análise dos dados foi realizada em três etapas distintas. Na primeira etapa, às entrevistas foi aplicada uma metodologia de análise de conteúdo, permitindo que informações do histórico familiar, a partir dos relatos das mães e sobre as concepções pedagógicas dos professores, fossem explicitadas e trabalhadas. Para além, analisaram-se os vídeos registros, considerando como elemento central os contatos físicos entre as crianças. Na segunda etapa, uma nova análise foi realizada junto ao material de vídeo, neste momento priorizando a análise microgenética dos episódios de regulações de comportamento no campo interativo. Na terceira e última etapa, a microgenética foi utilizada novamente, longitudinalmente, agora privilegiando os episódios interativos em que foram identificadas corregulações de comportamento. As três etapas de análise resultaram nos seguintes elementos: (1) a configuração do espaçolatividade pode interferir na quantidade de contatos físicos nas interações de pares, sendo o ritmo das atividades e a presença (ou ausência) direta do adulto um fator que influencia nas iniciativas da interação; (2) o contato físico se configurou por meio de diferentes comportamentos।gestos e em meio a diversas situações, representando as distintas, ambíguas e complementares formas de estabelecer contato com o outro; (3) há reciprocidade na busca por interação; (4) a atenção conjunta e o compartilhamento de objetos representam elementos fundamentais, permitindo a possibilidade da reciprocidade na troca de informações (corregulação); (5) foram identificadas, em todos os três casos, transformações na forma como as interações são constituídas ao longo do tempo, apresentando um gradativo aumento na sua complexidade; (6) as aprendizagens construídas nas corregulações de comportamento foram diversificadas, ora tangenciando aspectos sociais do processo de escolarização, ora se referindo a uma atividade específica; (7) a imitação aparece como elemento central e estruturador dos processos regulatórios; e, (8) o interesselenvolvimento dos pares no fazer conjunto com a criança pivô e o percurso histórico dessas interações no cotidiano escolar desempenharam um papel importante na criação das Zonas de Desenvolvimento Proximais e de desenvolvimento dos participantes pivôs. A partir dos resultados, defende-se que na interação de pares são criadas Zonas de Desenvolvimento Proximal, o que permite a reflexão sobre o papel do par no processo de aprendizagem, desenvolvimento e inclusão da criança com déficit intelectual em contextos escolares de Educação Infantil.

Palavras-chave: Interação de pares, Desenvolvimento Humano, Déficit Intelectual; Educação Infantil. 


\begin{abstract}
Ferreira, M. F. (2017). Children with intellectual disability and peer interaction in Early Childhood Education: reflections about development. Tese de doutorado, Faculdade de Filosofia, Ciências e Letras, Universidade de São Paulo, Ribeirão Preto.
\end{abstract}

This thesis focused on the theme of Inclusive Education from the analysis of peer's interactional processes in Early Childhood context. Within this complex and broad phenomenon, the investigative process concentrated on the possibilities of development of the child with intellectual deficit, discussing from the Historical-Cultural perspective the theoretical concept of Zone of Proximal Development, by Lev S. Vygotsky. We sought to understand the interactive processes of children with and without intellectual deficit in the school institutional context; to analyze how the relationships peer interaction are constructed and, in this construction, how they enable the transformation of potential abilities into real, in different activities. The specific objective was to identify if there is empirical evidence that would support the conceptual discussion that the impact of age-adjusted behavioral regulation and co-regulation could also be considered as an element that creates Zones of Proximal Development for children with intellectual deficit. In order to do so, we adopted a qualitative epistemological basis research process, based on theoretical contributions from the Network of Meanings, through three different data collection resources: video recording, semistructured interviews and the field diary. The participants were three children aged between three and a half and five years of two Early Childhood Education Institutions, diagnosed with intellectual deficit. In addition, the families of the three pivot children and their respective teachers were considered as participants. Data analysis was performed in three distinct stages. In the first stage, a content analysis methodology was applied to the interviews, allowing information on the family history from the mothers' reports and on the pedagogical conceptions of the teachers to be explained and worked out. In addition, we analyzed the video recordings considering as central element the physical contacts between the children. In the second stage, a new analysis was performed with the video material, prioritizing the microgenetic analysis of the episodes of behavior regulation in the interactive field. In the third and last stage, the microgenetic was used again, now privileging the interactive episodes in which behavioral modifications were identified. The three stages of analysis resulted in the following elements: (1) the configuration of space $\backslash$ activity may interfere in the amount of physical contacts in the pair interactions, with the activity rhythm and adult presence (or absence) being a factor influencing the Interaction initiatives; (2) physical contacts are shaped by different behaviors and gestures and in the midst of various situations, representing the distinct, ambiguous and complementary ways of establishing contact with the Other; (3) there is reciprocity in the search for interaction; (4) joint attention and the sharing of objects represent fundamental elements, allowing the possibility of reciprocity in the exchange of information (co-regulation); (5) transformations were identified in all three cases in the way interactions are constituted over time, presenting a gradual increase in their complexity; (6) the learning constructed in the behavioral configurations were diversified, sometimes involving social aspects of the schooling process, sometimes referring to a specific activity; (7) imitation appears as the central and structuring element of regulatory processes; And (8) the interest and involvement of peers in the joint development of the pivotal child and the historical course of these interactions in the daily school life played an important role in the creation of the Proximal Development Zones and the development of the pivot participants. From the results, we defend that the peer interaction creates situation, which can be understood as Zones of Proximal Development, and we point towards the reflection of the active role of peers to the learning, development and inclusion of children with intellectual disabilities within Early Childhood Educational contexts.

Key words: Peer interaction, Human Development, Intellectual Deficit; Early Childhood Education, 


\section{Lista de tabelas}

Tabela 1. - Informações gerais dos participantes da pesquisa

Tabela 2. - Descrição dos comportamentos observáveis utilizados para categorizar as regulações de comportamento no processo de mapeamento dos episódios de interação

Tabela 3. - Constituição dos espaços escolares - Estudos de caso Inácio e Ivan

Tabela 4. - Constituição dos espaços escolares - Caso Amanda

Tabela 5 - Quantitativo dos episódios de contato físico entre as crianças na fase I de análise - Caso Inácio

Tabela 6. - Dados gerais do mapeamento das interações realizado na fase I - Estudo de caso Inácio

Tabela 7. - Dados gerais do mapeamento de situações de interação realizado na fase I Estudo de caso Ivan

Tabela 8 - Quantitativo dos episódios de contato físico entre as crianças na fase I de análise - Estudos de caso Ivan

Tabela 9. - Quantitativo dos episódios de contato físico entre as crianças na fase I de análise - Estudos de caso Amanda

Tabela 10. - Dados gerais do mapeamento de situações de interação realizado na fase I -

Caso Amanda

Tabela 11. - Ocorrência de episódios de interação de acordo com a análise da regulação de comportamento na fase II

Tabela 12. - Mapeamento das interações em situações de compartilhamento de objetos ou atenção conjunta

Tabela 13 - Mapeamentos dos pares preferenciais em situações de regulação de comportamento com compartilhamento de objeto e atenção conjunta iniciados por Inácio

Tabela 14 - Mapeamento das regulações de comportamento envolvendo o par Lorena no estudo de caso Inácio

Tabela 15 - Mapeamentos das interações com os pares em situações de regulação de comportamento com atenção conjunta iniciadas por Ivan

Tabela 16 - Mapeamentos das interações com os pares em situações de regulação de comportamento com atenção conjunta iniciadas por Amanda

Tabela 17 - Mapeamentos das interações de Amanda em situações de regulação de comportamento com atenção conjunta iniciadas pelos pares 
Tabela 18 - Material selecionado para a terceira fase de análise de dados - Quantitativo de episódios de corregulação de comportamento com atenção conjunta ou compartilhamento de objeto 


\section{Sumário}

1 Introdução

1.1 Desenvolvimento humano na perspectiva histórico-cultural 1

1.1.1 A Zona de Desenvolvimento Proximal

1.1.2 As contribuições da Rede de Significações (RedSig) para a compreensão dos processos de desenvolvimento humano

1.3.1 Os conceitos de deficiência e suas transformações ao longo do tempo

1.3.2 A caracterização do déficit intelectual e o desenvolvimento a partir das contribuições de Vygotsky

1.3.3 Discutindo o conceito de desenvolvimento dentro da perspectiva do trabalho com a criança com déficit intelectual na atualidade

- Primeiro momento: entrevistas e diário de campo

- Segundo momento: vídeo registro dos processos interacionais e diário de campo

4.1 Entrevista com os familiares: entendendo a perspectiva dos pais sobre a história de cada sujeito

- Estudo de caso Inácio

- Estudo de caso Ivan

- Estudo de caso Amanda 
4.2 Entrevista com professores: aspectos pedagógicos e as percepções docentes sobre a participação da criança no espaço escolar

- Estudo de caso Inácio

- Estudo de caso Ivan

- Estudo de caso Amanda

4.3 Vídeo-registros e notas do diário de campo: as interações em análise, o mapeamento e a microgenética

4.3.1 Resultados da fase I - Mapeamento 1: o contato físico

- Estudo de caso Inácio

- Estudo de caso Ivan

- Estudo de caso Amanda

4.3.2 Reflexões sobre os resultados da fase I 106

4.3.3 Resultados da fase II - Mapeamento 2: a regulação de comportamento 110

- Inácio

- Ivan

- Amanda

4.3.4 Reflexões sobre os resultados da fase II 156

4.3.5 Resultados da fase III - Análise microgenética das interações 161

- Inácio

- Ivan

- Amanda

4.3.6 Reflexões sobre os resultados da fase III

5 Discussão geral

6 Considerações finais $\quad 219$

7 Referências $\quad 220$

$\begin{array}{ll}\text { Anexos } & 244\end{array}$ 


\section{Introdução}

Na condução de um trabalho investigativo, cujo foco são os processos interacionais de pares de crianças (dentre elas, crianças com deficiência intelectual) e cuja pergunta orientadora recai sobre a análise do processo de desenvolvimento, faz-se necessário explicitar a definição conceitual que sustenta os objetivos, as hipóteses, as análises e embasa as discussões pretendidas sobre os referidos processos.

Inicialmente, é preciso destacar que, falar sobre desenvolvimento, a partir de processos interacionais e, ainda, relacioná-los ao fenômeno do déficit intelectual, não é uma tarefa simples. Tais questões representam constructos teóricos construídos e debatidos ao longo de toda a existência da Psicologia enquanto Ciência e em outros diferentes campos de atuação.

Para explicitar a construção teórica sobre desenvolvimento humano abordado neste trabalho, o tema será apresentado a partir de alguns pontos de reflexão, a saber: (1) o desenvolvimento humano na perspectiva histórico-cultural, enfocando a discussão conceitual da Zona de Desenvolvimento Proximal e trazendo para o diálogo as contribuições da Rede de Significações enquanto aparato teórico-metodológico para a compreensão dos processos de desenvolvimento; (2) os processos interacionais e as construções de cultura na infância; e, (3) o desenvolvimento da criança com déficit intelectual, trazendo uma reflexão sobre aspectos das transformações sociais ocorridas ao longo do tempo em relação ao processo de diagnóstico dessa condição e as perspectivas para o trabalho educacional na atualidade.

\subsection{O desenvolvimento humano na perspectiva histórico-cultural ${ }^{1}$}

Ao longo desse capítulo introdutório, optou-se por elencar, dentro da imensidão teórica pertinente a esse tema, alguns elementos específicos que embasaram e auxiliaram a coleta, análise e discussão dos dados dessa pesquisa. Não é objetivo então, narrar biografias ou apontar percursos históricos das teorias de desenvolvimento humano que, em outros textos, já estão mencionados com bastante propriedade, mas trazer alguns elementos desse campo, já com base em conceitos teóricos específicos, para a análise do fenômeno aqui estudado.

Na história da Psicologia, o desenvolvimento humano tem sido um tema recorrente em estudos e construções teóricas ao longo de todo século XX. Com uma base predominantemente positivista de

\footnotetext{
${ }^{1}$ Antes de iniciarmos a discussão proposta, cabe evidenciar que, em se tratando de referenciais e textos cuja origem (em russo) não é acessível e que sua tradução nem sempre é proveniente da totalidade da obra original, serão feitas algumas interpelações específicas sobre determinados termos com o intuito de justificar a escolha da bibliografia.
} 
pesquisa, esse campo tem, em grande parte, estudos com o objetivo de se estabelecer parâmetros ou normas que explicitem (através de produtos nos comportamentos) determinadas etapas e prazos a serem percorridos ao longo da infância e adolescência, principalmente. Os teóricos que se propuseram a estudar tal processo, assim o fizeram através de um sistema de observações comportamentais e fisiológicas que, ao final da análise, levou a uma fragmentação e compartimentação de comportamentos e reações em determinados espaços de tempo, ao longo do desenvolvimento do indivíduo (Dasen \& Mishra, 2000). Dessa forma, de maneira genérica, quando se fala em processo de desenvolvimento, associa-se-o a etapas ou estágios que determinam o percurso para esse processo (Bee, 1997; 2003).

Para além da fragmentação do processo de desenvolvimento em etapas estanques, a história dos estudos em Psicologia do Desenvolvimento é também marcada pelas dicotomias mente versus corpo, cognição versus afeto e interno versus externo (como discutem Smolka, Amorim \& Leite, 2016), contribuindo, ao longo do processo de especialização das ciências na divisão e subdivisão de marcadores, ou categorias de estudo, tais como: desenvolvimento físico (motor, neurológico, muscular e etc.), desenvolvimento cognitivo (capacidade de raciocínio lógico e funcionamento neurológico) e desenvolvimento emocional (comportamentos sociais), que servem como base para diferentes interpretações ao longo dos anos de vida das pessoas (Gesell \& Amatruda, 2000). Os comportamentos observáveis em cada uma dessas categorias eram e ainda são selecionados a partir das similaridades presentes num conjunto de sujeitos, implicando em um processo de homogeneização e padronização do fenômeno.

As diferenças passíveis de observação (comportamento e corpo físico) foram interpretadas como transformações e identificadas entre uma faixa etária e outra, o que posteriormente designouse de fases de desenvolvimento e caracterizou-se por ser objeto de estudo de muitos teóricos (Garcia, 2003). Todo esse procedimento tem sido de extrema relevância para a compreensão do fenômeno e, independente da metodologia aplicada, os referenciais encontrados contribuíram para o conhecimento sobre o ser humano.

Entretanto, caminhos metodológicos que considerem a inter-relação entre comportamentos e contextos (Palacios, 1995) têm guiado outros estudos sobre o desenvolvimento humano. Nesses estudos, como discute o autor, o desenvolvimento humano é considerado como resultante de transformações que relacionam três elementos centrais, a saber: (1) a etapa de vida em que a pessoa se encontra; (2) as circunstâncias culturais, históricas e sociais nas quais sua existência transcorre; e, (3) experiências particulares e não generalizáveis a outra pessoa. A análise do desenvolvimento pode ser feita a partir da avaliação desses elementos centrais e identificado diante disso o processo 
(período) em que a criança/pessoa se encontra. A periodização é realizada a partir da compreensão dessas transformações e suas intercorrências na vida social do indivíduo.

Nesta definição, embora já avance na consideração da multiplicidade fatorial constituinte do fenômeno do desenvolvimento humano, ainda são colocados separadamente os aspectos sociais, culturais e vivenciais do indivíduo. Ao mesmo tempo, consideram-se esses elementos como aspectos que influenciam, ainda deixando em aberto possibilidades de se analisar esse processo de forma fragmentada.

Tal como propõe Cairns, Elder e Costelo (1996), a ciência do desenvolvimento contempla as teorias sociais, psicológicas e biocomportamentais, correlacionando-as ao contexto histórico pertinente. O desafio imposto e os questionamentos derivados, entretanto, residem em se abordar esse processo de desenvolvimento considerando os elementos, usualmente identificados e tratados como instâncias separadas, como composições interdependentes, partícipes de um sistema aberto. Isso nos leva a tratar da noção de desenvolvimento, a partir da perspectiva histórico-cultural.

A teoria histórico-cultural embasa-se em trabalhos de um grupo de estudiosos que, liderado pelo psicólogo ${ }^{2}$ Russo Lev Semionovich Vygotsky (1896 -1934), vai trazer um impacto significativo tanto para a Psicologia quanto para a Educação russa pós revolução ${ }^{3}$ (Oliveira, 1999; Toassa, 2009). Embora o autor não tenha, em momento algum, assim denominado seus constructos teóricos (histórico-cultural), esta é a ideia que está implícita neste conceito e que transforma a maneira como se enxerga o processo de desenvolvimento humano e, consequentemente, a forma como as construções sociais e constituição pessoal ocorrem (Prestes, 2012; Valsiner, 1992; 1993; Vasconcelos \& Valsiner, 1995).

A partir da perspectiva histórico-cultural considera-se a dialética e a indissociabilidade desses elementos apontados anteriormente, destacando-se que a constituição do sujeito acontece ao mesmo tempo e na medida em que se constituem também o contexto social, através da ação do/junto ao outro (Vygotsky, 2007; Wallon, 2007). Para além, o conceito de desenvolvimento nas obras de Vygotsky adquire uma característica essencialmente histórica, distinguindo-se de outras concepções de desenvolvimento (Smolka et. al. 2016).

"Nesta perspectiva, o desenvolvimento cultural do indivíduo é visto como uma história pessoal intrinsecamente entretecida às práticas culturais e à história humana. O desenvolvimento especificamente

\footnotetext{
2 Vygotsky foi também advogado e filósofo, seguindo a carreira de psicólogo após a Revolução Russa, em 1917.

3 Referência à Revolução Russa de Outubro de 1917, a qual finda com o Império Tzarista e implementa o socialismo como forma de estrutura político-social.
} 
humano está ancorado na participação e na apropriação da cultura" (Smolka et. al. 2016, p.75)

Neste sentido, Smolka (2002) ressalta o papel da coletividade para o desenvolvimento afirmando que o comportamento humano é produzido e transmitido pela atividade do ser humano ao longo de sua existência na coletividade. É essa coletividade que define a natureza social do desenvolvimento humano, significando que "sua dimensão orgânica é impregnada pela cultura e marcada pela história" (idem, p.80).

Os diferentes sentidos que o termo desenvolvimento vai adquirindo ao longo do trabalho de Vygotsky deve ser entendido a partir da contextualização de seu uso e do fato de que o pensamento de Vygotsky e a construção de seus pressupostos está intrinsicamente ligado às referências metodológicas marxistas para a construção de uma ciência e um processo de investigação do psiquismo. Isso significa que o pensamento dialético, a contradição construtiva e, principalmente, a busca pela compreensão do comportamento humano por meio de elementos sociais, são pontos presentes no seu processo de raciocínio e, consequentemente, revelados nos conceitos e na escrita de seus textos ao longo da sua vida (González Rey, 2011; Oliveira, 1999).

Ainda, ressalta-se que Vygotsky tinha uma preocupação em contribuir com a transformação social, em especial com a educação na Rússia pós-revolução (Kozulin, 1998). Para além disso, seus inúmeros trabalhos trazem reflexões e constituem um referencial teórico para se pensar o processo de desenvolvimento humano, repercutindo em outros contextos sociais e outras áreas de conhecimento (Van Der Veer \& Valsiner, 2014).

Segundo Prestes (2012), a melhor definição do termo histórico-cultural é dada por A. N Leontiev (1983), afirmando que, ao longo do desenvolvimento, “as funções naturais são substituídas pelas funções culturais, que são o resultado de assimilação dos meios historicamente elaborados para orientar os processos psíquicos” (p.25). Segundo González-Rey (2011), é na segunda fase dos trabalhos de Vygotsky (1928-1931) que acontece a afirmação de uma teoria histórico-cultural para explicar o desenvolvimento das funções psíquicas superiores ${ }^{4}$, o que trouxe uma nova perspectiva para a Psicologia quanto à compreensão da natureza social do ser humano.

Segundo Wertsch, Del Rio e Alvarez (1995), Vygotsky e seus colaboradores fizeram diversos e significativos apontamentos sobre os 'domínios genéticos' a partir da análise de diferentes culturas, concluindo que a linguagem constitui marcantes diferenças nos processos de pensamento dos indivíduos, provenientes de contextos culturais distintos. A definição do termo histórico-cultural,

\footnotetext{
4 Há uma discussão se o termo correto não seria funções psicológicas superiores. Como não se trata do objetivo do trabalho a discussão desse tema em específico, respeitar-se-á o termo utilizado pelo autor, apresentado nas traduções de seu texto.
} 
para referir-se aos trabalhos de Vygotsky, dá-se, então, a partir do foco e da linha de pensamento investigativo conduzido pelo autor.

A compreensão do desenvolvimento humano a partir desses novos conceitos desdobra-se e provoca transformações significativas na maneira como se pensa a organização do processo de escolarização de uma sociedade, processo esse que foi um dos objetivos de Vygotsky ao estruturar seu trabalho. Como destaca Iarochevski (2007) citado em Prestes (2012),

"É exatamente entre 1925 e 1930 que os estudos do grupo liderado por Vygotsky provocam uma revolução na interpretação da consciência como forma especial de organização do comportamento do homem" (p. 14).

"Esses estudos começam a desempenhar papel importante para a formação de novos professores, deixando no passado a "velha escola", pois para formação de um homem novo fica perfeitamente claro que, do ponto de vista da influência consciente sobre o curso do processo educativo, a nova escola surge como uma das tarefas essenciais" (Lunatcharski, 1988, p. 15 como citado em Prestes, 2012).

Dessa forma, na base da proposição de Vygotsky $(2007)^{5}$, o desenvolvimento da psique humana é de natureza social. Isso significa que aquela se constitui através do processo de interiorização daquilo que é construído na atividade coletiva, para a significação do sujeito. É a transformação do interpsíquico para o intrapsíquico que ocorre o desenvolvimento das funções psíquicas superiores e, consequentemente, possibilita que o indivíduo possa controlar não só o outro, como a si mesmo. Por essa premissa, entende-se que o ser humano necessita da ação do outro para significar suas próprias ações, orientando-as a partir dessas demandas do meio. A natureza social das funções psicológicas superiores é o que garante ao humano as suas inúmeras possibilidades de existência e de significação de mundo.

Entretanto, falar que o ser humano tem uma natureza social não significa para Vygotsky ignorar ou anular o aspecto biológico, mas afirmar que esses aspectos biológicos não conduzem o desenvolvimento humano por si só.

\footnotetext{
5 Embora haja discordância nas diferentes traduções das obras de Vygotsky, aparentemente essa ideia é comum em todos os livros, nacionais e com tradução na língua inglesa e espanhola. Dessa forma, a citação fica sobre a tradução brasileira feita pela editora Martins Fontes, uma das mais conhecidas no Brasil.
} 
"O indivíduo nasce como ser biológico, fruto da história filogenética da espécie e que, através da participação na cultura, constitui-se como um ser sócio-histórico. (...) nasce com as chamadas funções elementares, de natureza biológica, e, a partir da inserção cultural, constituem-se as chamadas funções superiores, que caracterizam o ser humano" (Smolka et. al. 2016, p.76).

Assim, para Vygotsky, os aspectos biológicos estão intrinsicamente ligados aos fatores sociais, pois se transformam ao longo do tempo a partir das diferentes formas de assimilação dos sistemas de signos. Em outras palavras, a depender da maneira como o indivíduo passa pelas experiências propiciadas pelo meio é traçado o percurso para seu desenvolvimento, dando origem ao conceito de Perezhivanie $^{6}$ (Vygotsky, 2001).

Perezhivanie, ou vivência, foi inicialmente ${ }^{7}$ associado aos conceitos de emoção, criatividade e motivação dando origem, pela primeira vez, à unidade intelecto e afeto. Ele foi desenvolvido por Vygotsky nos anos finais da sua vida, na ideia de que ela (a vivência) é a unidade definida por todas as características da personalidade com todas as características do meio (González-Rey, 2016). A vivência seria "aquilo que transforma radicalmente para a criança o ambiente que a cerca" (Prestes, 2012. p. 27), "a singular forma pela qual a criança percebe e sente as influências sociais " (GonzalezRey, 2016, p. 5), resultando na unidade que representa (e assim define) o desenvolvimento da criança.

Para além dessas duas compreensões (Prestes, 2012; González-Rey, 2016), em seus estudos empíricos com crianças pequenas, Veresov e Fleer (2016) propõem outras duas interpretações ou olhares para o conceito Perezhivanie: (1) enquanto um prisma de refração - elemento que permitiria que a emoção e a intelectualidade da criança transpassassem na experiência social e, da mesma forma que um prisma muda a direção da luz, a Perezhivanie definiria a experiência vivida. Indícios empíricos dessa compreensão conceitual estariam, por exemplo, nos desenhos de crianças que passaram pela mesma experiência. Os objetos e os conteúdos de cada desenho são singulares, mostrando as diferentes vivências; (2) enquanto a unidade de consciência - elemento de desenvolvimento da completude, em que as mudanças concretas vividas pelas crianças trariam mudanças para toda a organização da sua consciência. Os exemplos discutidos a partir dessa ideia são os processos de brincadeira de faz de conta, em que as crianças "sentem elas mesmas enquanto aquela que brinca (players) dentro da brincadeira ao mesmo tempo que são elas crianças acima da brincadeira, conduzindo e inventando o processo de brincar" (Veresov \& Fleer, 2016, p.333). Esse

\footnotetext{
${ }^{6}$ A tradução mais adequada para este termo no português é vivência (Prestes, 2012), que será adotada neste trabalho.

${ }^{7} \mathrm{O}$ conceito foi apresentado por Vygotsky pela primeira vez no livro A Psicologia da Arte.
} 
conceito talvez seja um dos mais importantes conceitos do trabalho de Vygotsky para se entender o foco (ou recorte específico escolhido) de desenvolvimento neste estudo. A vivência, conforme afirma Prestes (2012), é o conceito de Vygotsky que abre espaço para pensarmos nas diferentes formas possíveis de ser humano, indicando caminhos para se olhar para os processos interacionais nos diferentes vetores e contextos, uma vez que a vivência ressalta a individualidade presente nesse processo de desenvolvimento contextual. E, ao mesmo tempo, é um conceito que coloca em evidência a relevância dos recursos da criança para a compreensão do processo de desenvolvimento (GonzalezRey, 2016). Neste sentido, se o meio não influencia o desenvolvimento de fora para dentro, é na vivência (enquanto unidade e processo) que se encontram as possibilidades de se investigar o fenômeno do desenvolvimento.

De forma geral, reconhece-se na teoria histórico-cultural respaldo conceitual para ampliar a discussão sobre a compreensão dos processos de desenvolvimento de crianças com déficit intelectual na atualidade. Ela enfatiza a necessidade de se olhar para as construções sociais dentro desse processo, ressalta a importância sine qua non do outro no processo de desenvolvimento e orienta quanto à discussão de alguns elementos teóricos importantes como, por exemplo, o próprio conceito de desenvolvimento e déficit intelectual que, ao longo de um processo histórico, ganham diferentes significados e suscitam diferentes práticas nos distintos contextos sociais possíveis. Entretanto, é sabido que a teoria histórico-cultural não finda nos trabalhos de Vygotsky e que, posterior a sua morte, inúmeros estudos foram desencadeados, inspirados em seus pressupostos.

Atualmente, a partir do estudo de teóricos que continuaram o trabalho iniciado por Vygotsky, pode-se entender que existem duas grandes linhas de pesquisa e pensamento sobre o desenvolvimento humano dentro da perspectiva histórico-cultural (González Rey, 2011). Uma corrente que considera o materialismo como ponto central da discussão do desenvolvimento, enxergando as transformações do indivíduo ao longo de sua vida a partir dos seus aspectos cognitivos, entendendo os elementos externos/internos como diferentes e relacionais, tendo a atividade como o foco central dos estudos e discussões. Leontiev (2005a; 2005b; 2012), Solovieva e Quintanar Rojas (2010), Talizina (2009) são alguns dos autores que defendem esta corrente teórica. Cada um, a seu modo e tempo, desenvolveu e vem desenvolvendo diferentes aspectos da teoria da atividade, discorrendo sobre o desenvolvimento humano.

Outra proposta de compreensão do processo de desenvolvimento pela perspectiva históricocultural é aquela que considera a subjetividade e a sua constituição como fatores primordiais para a compreensão desse processo. Nesse sentido, entende-se os elementos internos/externos como entrelaçados, indissociáveis, não sendo possível analisá-los de forma separada, pois se trata de uma 
unidade. Pode-se encontrar tais defesas em textos de Vasily Davidov, P. Zinchenko, L. A. Venguer (González-Rey; 2004a; 2011; Garcia, 2003).

Essas duas correntes de desenvolvimento da teoria histórico-cultural são frutos inclusive de um processo dialético envolvendo o próprio autor que, ao longo de sua produção, ora focou seus estudos na compreensão da unidade cognição/afeto, ora preocupou-se com questões voltadas à instrução e às contribuições ao processo de escolarização (resultado do contexto social político no qual se encontrava). Não se trata do resultado de uma ambivalência ou uma contradição teórica, mas de uma complementaridade no estudo geral sobre o desenvolvimento humano e sobre a necessidade de uma reformulação na estrutura educacional/social da época, que deve ser analisada dentro da perspectiva da dialética defendida pelo próprio autor (González Rey, 2011).

Assim, dentro das inúmeras contribuições de Vygotsky para a Psicologia e para a Educação, entende-se que seja pertinente à discussão ora pretendida considerar o próprio processo dialético do autor, trazendo discussões específicas do desenvolvimento dentro do contexto escolar, simultaneamente explorando a compreensão do desenvolvimento humano como uma unidade entre cognição e afeto. E, neste sentido, desdobrar o olhar para o contexto educacional atual, com vistas a compreender - dentro dessa perspectiva - o desenvolvimento humano a partir do fenômeno interacional entre as crianças com déficit intelectual e seus pares com desenvolvimento típico.

Mas, tratar da noção de desenvolvimento a partir da obra de Vygotsky é tarefa complicada já que a definição do que seja o desenvolvimento humano aparece volatilizada dentro de todo o complexo teórico. Cada autor, dentro dessa abordagem, vai ainda ter um olhar específico e uma proposta de análise para compreender o processo, tornando a conceituação um movimento amplo.

Contudo, o que se pode afirmar em relação ao conceito é que, dentro dessa perspectiva, tratase de um processo de transformação contínuo ao longo da existência humana em diferentes composições/contextos sociais. O desenvolvimento humano é de natureza social, ao mesmo tempo histórico e individual, e nele, o homem não se desenvolve, mas constrói a si próprio na (sua) atividade mediada semioticamente (Smolka et.al., 2016). Assim, "são as relações sociais nas quais o sujeito está envolvido que podem explicar seus modos de agir, de pensar, de se relacionar" (Smolka 2002, p $81)$.

$\mathrm{Na}$ teoria histórico-cultural, ainda, fica explicitada a relevância da aprendizagem no processo de desenvolvimento e demarcado o papel das interações na constituição do sujeito. A aprendizagem estimula e avança o desenvolvimento, mas não estabelece com ela uma relação de dependência, como proposto por Piaget (Vygotsky, 2010). A interação se constitui como processo primordial para o desenvolvimento, uma vez que toda função psíquica superior perpassa primeiro como atividade 
coletiva, social, ou seja, como função interpsíquica; segundo, como atividade individual, como modo interior de pensamento da criança, como função intrapsíquica (Vygotsky, 2010 p.483).

Sobre a periodização do desenvolvimento, Vygotsky (1996) não vai propor uma sequência explícita e fechada, mas vai indicar que o desenvolvimento seja observado a partir daquilo que provoca ou que desencadeia, as transformações no indivíduo - a consciência e a personalidade. É na dinamicidade presente no processo que a periodização pode ser observada, tendo como principal demarcação novas configurações na personalidade do indivíduo (Oliveira \& Teixeira, 2002). Tal processo pode ser percebido através da observação de determinados momentos de crise, os quais podem ser definidos por mudanças que são bruscas e marcantes, num lapso de tempo relativamente curto (Oliveira \& Teixeira, 2002. pp. 34).

Neste período de crise, as crianças podem apresentar conflitos mais ou menos agudos, mudança de atividade guia, podendo inclusive acarretar dificuldades no processo de escolarização. O “[...] conteúdo negativo do desenvolvimento nos períodos críticos é tão somente a faceta inversa ou velada das mudanças positivas da personalidade que configuram o sentido principal e básico de toda idade crítica" (Vygotsky, 1996.pp. 259). O sentido da análise do desenvolvimento reside, portanto, em "encontrar a mudança na personalidade da criança em sua totalidade, dentro da qual todos os seus elementos ficam esclarecidos, uns em qualidade de premissas, outros como momentos determinados (Vygotsky, 1996. pp.338).

Entende-se, então, que a periodização está a serviço da compreensão de um processo histórico individual dentro do coletivo. As crises, conforme aponta Vygotsky, podem ser pertinentes a determinada faixa etária, mas são suscetíveis ao contexto histórico, sociallsubjetivo do sujeito. Assim, entende-se que o autor defenderá que, mais importante do que compreender o que cada criança deveria ou não fazer em determinado momento da vida é compreender como acontece o percurso de desenvolvimento de cada criança, uma vez que para o autor esse é um processo individualizado.

"Sabemos por uma grande quantidade de pesquisas - a que no momento apenas podemos aludir - que o desenvolvimento das funções psico-intelectuais superiores na criança, dessas funções especificamente humanas, formadas no decurso da história do gênero humano, é um processo absolutamente único” (Vygotsky, 2012a, p. 114).

Em se tratando de um percurso único (singular), a unidade de análise desse desenvolvimento para Vygotsky será a própria Zona de Desenvolvimento Proximal. Neste sentido, quando Vygotsky 
(2008; 2007; 2010) traz o conceito de Zona de Desenvolvimento Proximal ${ }^{8}$, assim o faz, em decorrência da preocupação com os processos diagnósticos e com uma atuação prática que efetivamente resulte em desenvolvimento. A sistematização do conceito de Zona de Desenvolvimento Proximal esclarece e sustenta a defesa de Vygotsky sobre qual é a relação entre aprendizagem e desenvolvimento, que sustenta que "só é boa a aprendizagem que supera o desenvolvimento" (Vygotsky, 2010, p.482) e que a avaliação do processo de desenvolvimento humano é mais complexa do que simplesmente a testagem de habilidades cognitivas específicas num dado momento de vida do sujeito.

\subsubsection{A Zona de Desenvolvimento Proximal}

O conceito de Zona de Desenvolvimento Proximal (ZPD) pode ser considerado como um dos mais relevantes da produção bibliográfica de Vygotsky, revolucionando a compreensão sobre os processos de desenvolvimento humano e sua intersecção com a educação. Foi com a discussão desse conceito que se ampliaram as maneiras de se estruturar a análise de desenvolvimento e o diagnóstico pedagógico realizados principalmente em contextos escolares, repercutindo em como o processo de ensino/aprendizagem se organiza (Prestes, 2012). Mas, o que é a Zona de Desenvolvimento Proximal (ZDP)?

Nessa apresentação, é importante deixar claro que a ZDP se trata de um conceito teórico, abstrato, não acessível a mensuração quantitativa ou ligado a uma identificação comportamental única. A definição de Zona de Desenvolvimento Proximal (Vygotsky, 2007), é caracteriza pela

“(...) distância entre o nível de desenvolvimento real, que se determina através da solução independente de problemas e o nível de desenvolvimento potencial, determinado através da solução de problemas sob orientação de um adulto ou em colaboração com companheiros mais capazes" (p. 97).

A ideia construída por detrás desse conceito é que, primeiramente, o ser humano desenvolvese a partir da interação com o outro; a constituição do sujeito se dá por meio da mediação dos signos culturais. Em segundo, que o desenvolvimento humano não pode ser analisado simplesmente pelo que o indivíduo apresenta de resposta naquele momento em específico, mas que também deve ser considerado aquilo que o indivíduo faz comla partir da ajuda do outro. Entretanto, diferentes leituras são feitas a partir da análise temporal do trabalho de Vygostky e dos contextos em que esse conceito

\footnotetext{
8 Respeitou-se o termo contido em Vygotsky (2007).
} 
está sendo aplicado. Holzman (1997; 2010), ao enfatizar a forma como Vygotsky enxerga o desenvolvimento e a aprendizagem enquanto totalidade, aponta que o conceito de ZPD aparece ao longo dos trabalhos do autor com três diferentes enfoques. O primeiro, é o enfoque individual, em que a ZPD é discutida enquanto "uma característica ou propriedade individual da criança" (Holzman, 2010, p. 28). Por essa perspectiva, a ZPD se transforma no elemento que produz a unidade de medida do potencial de desenvolvimento. O segundo enfoque é denominado diádica, em que a ZPD acontece na interação com o outro, justificando assim a importância das atividades compartilhadas e dando origem a outros conceitos, tais como a forma de auxílio denominada de prótese (prosthesis) (Shotter, 1989) e scaffolding (Wood, Bruner \& Ross, 1976). A terceira perspectiva é a denominada coletiva. Nesta, a ZPD não se constitui no indivíduo, tampouco em uma única díade de interação, a chave do conceito estando no fazer conjunto, coletivo, compartilhado. A ZPD é enxergada por esse prisma muito mais enquanto um processo do que uma entidade espaço-temporal, enquanto uma atividade ao invés de uma Zona.

De forma geral, o conceito de ZDP aparece em oito diferentes textos produzidos pelo autor (Prestes, 2012). Entretanto, apenas seis estão disponíveis com tradução para o português. São eles: (1) O papel do brinquedo no desenvolvimento (Vygotsky, 2007. p.107), também traduzido por $A$ brincadeira e o papel no desenvolvimento psíquico da criança (Vygotsky, 2008); (2) A análise pedológica do processo pedagógico (Vygotsky, 2010. p.547); (3) Desenvolvimento dos conceitos cotidianos e científicos escolares (Vygotsky, 2010. p. 517); (4) A dinâmica do desenvolvimento mental do aluno escolar em função da aprendizagem (Vygotsky, 2010. p.489); (5) Aprendizagem e desenvolvimento intelectual na idade escolar (Vygotsky, Luria \& Leontiev, 2012, p.103), também traduzido por O problema do ensino e do desenvolvimento mental na idade escolar (Vygotsky, 2005. p. 25) ou ainda por Interação entre aprendizagem e desenvolvimento (Vygotsky, 2007. p. 87); e, (6) A construção do pensamento e da linguagem, que também pode ser encontrado por Pensamento e linguagem (Vygotsky, 2001).

Em todos esses textos, Vygotsky discorre sobre a Zona de Desenvolvimento Proximal, ora apontando implicações para a análise do desenvolvimento humano, ora discorrendo sobre a relação entre desenvolvimento e aprendizagem e o papel da instrução escolar neste processo. Vygotsky também se referiu a esse conceito trazendo a ideia de criação de uma outra maneira de acessar e entender o desenvolvimento humano, uma forma qualitativa e compreensiva dos processos individuais. O conceito é uma tentativa de descrição teórica do potencial de aprendizagem que deveria ser considerado ao longo do processo de aprendizagem (Vasconcelos \& Valsiner, 1995).

A discussão sobre os processos de desenvolvimento a partir desse conceito foi responsável por grandes reestruturações na Educação russa (e, posteriormente, ao redor do mundo) e é até hoje fonte 
para os mais diversos trabalhos tanto na área da Psicologia do Desenvolvimento quanto da Educação (Warford, 2011; Allal \& Ducrey, 2000; Batista, Cardoso \& Santos, 2006; Fani \& Ghaemi, 2011; Freitas, 2006; Pino, 2000), uma vez que, pela compreensão defendida por Vygotsky, há uma mudança no paradigma do que seja considerado desenvolvimento. Ao invés de se explicar esse processo por sistemas (ciclos) específicos e fechados de ações (mensurados e classificados por determinadas capacidades individuais na execução de atividades), para Vygotsky o desenvolvimento humano é constante, estruturado por sistemas abertos e em relação direta com a dinâmica da transformação da personalidade. A análise do percurso desse processo acontece pelo potencial existente em cada indivíduo para novas aprendizagens, o que seria justamente a ideia conceitual da Zona Desenvolvimento Proximal (Oliveira \& Teixeira, 2002).

No entanto, mesmo sendo um conceito significativamente debatido em diferentes momentos do trabalho do autor, com repercussões para inúmeros outros estudos, a dialética contida em seu pensamento no conjunto total de sua obra e a dificuldade do acesso a sua escrita original, torna a compreensão desse (e outros) conceito(s) um processo complexo. Se a terminologia não fosse desafio suficiente, a Zona de Desenvolvimento Proximal é um conceito teórico abstrato, que traz mais descrição do que explicação em como o autor entendia o processo de desenvolvimento. Remanescem assim, possibilidades de interlocução entre a teoria proposta e as práticas ou reflexões no âmbito da compreensão dos processos de desenvolvimento e uma diversidade de possibilidades na perspectiva da prática pedagógica (Vasconcelos \& Valsiner, 1995; Valsiner 2013).

Além disso, é determinante resgatar o próprio contexto histórico e social em que esse conceito foi pensado e a qual público e com qual objetivo os textos em que ele aparece foram produzidos. No caso específico do conceito de Zona de Desenvolvimento Proximal, os textos foram produzidos com a finalidade de comunicar suas ideias ao público acadêmico (das áreas da educação, defectologia e pedologia), num dado momento de sua trajetória, em que havia uma intensa produção voltada para o contexto escolar, com o objetivo de uma reforma educacional pautada em uma nova formação de professores e na responsabilização desses para o processo educativo. Aliado a isso, esses textos não foram traduzidos na íntegra, deixando de fora trechos onde o autor explicita de maneira mais ampla o que cabe ao conceito desenvolvido (Prestes, 2012).

Dessa forma, a discussão sobre o conceito de Zona de Desenvolvimento Proximal e sua aplicabilidade prática no campo educacional na atualidade, bem como a interlocução com as discussões sobre desenvolvimento humano desenvolvidas na área da psicologia escolar/educacional ou na psicologia do desenvolvimento tem sido construída através de distintas significações e entendimentos conceituais. Essa realidade, quando colocada na discussão sobre a educação especial 
brasileira do século XXI, relança questionamentos, sejam eles relacionados ao real sentido conceitual do autor, ou na amplitude do alcance prático que o conceito permite com que se trabalhe.

Muitos desses questionamentos podem ainda ser fruto de confusões terminológicas ou ainda interpretações equivocadas nas traduções pois, como já mencionado anteriormente, um dos grandes desafios para a compreensão do pensamento de Vygotsky é o acesso a sua produção original em russo. Ao tomar-se como exemplo a tradução atribuída ao conceito de Zona de Desenvolvimento Próximo (proximal, ou imediato ${ }^{9}$ ), há recentemente uma discussão sobre a adequação do termo “proximal” como tradução do que originalmente em russo é bjijaichego (Prestes, 2010; 2012). Nessa discussão é apontado que, embora tenham sido amplamente difundidos, os termos acima citados não são adequados para explicitar o que o autor queria dizer e que,

“(...) quando se usa zona de desenvolvimento proximal ou imediata não está se atentando para a importância da instrução como uma atividade que pode ou não possibilitar o desenvolvimento. Vygotsky não diz que a instrução é garantia de desenvolvimento, mas que ela, ao ser realizada em uma ação colaborativa, seja do adulto ou entre pares, cria possibilidades para o desenvolvimento" (Prestes, 2012. p. 190).

Para Prestes (2010; 2012), o termo mais adequado para descrever o que a palavra russa significa é iminente ${ }^{10}$. A discussão terminológica é importante neste ponto porque possibilita uma ampliação da compreensão do papel do outro no processo de desenvolvimento e abre perspectivas de entendimento para as diferentes interações dentro e fora do contexto escolar. Outro importante fator que contribui para tantas dificuldades na precisão conceitual é, segundo Prestes, Tunes e Nascimento (2013) que, apesar de muito difundido, o conceito também é muito banalizado, principalmente quando analisado isolado do conhecimento sobre vida e obra do autor, o que acarreta em uma limitação na compreensão da totalidade da sua produção.

A partir do que foi exposto e, em se tratando do interesse em compreender os processos interacionais de pares na pré-escola, tendo como referência de análise o desenvolvimento de crianças com déficit intelectual, para o presente estudo identifica-se particular relevância à discussão desse conceito por dois motivos. Em primeiro lugar, por ser através dele que o autor traz um novo

\footnotetext{
9 O que, segundo Prestes (2012), pode ter acontecido em decorrência direta da versão em inglês Zone of proximal development.

10 Entende-se que a tradução não se trata de um processo simples e que não se resume em achar os sinônimos nas diferentes línguas, mas de transpor uma ideia e um pensamento que está circunscrito em um tempo e espaço de produção. Destaca-se, entretanto, que os demais textos traduzidos até então e o acúmulo de estudos realizados por diferentes pesquisares também são considerados e que, neste trabalho, o referido conceito continuará sendo denominado por Zona de Desenvolvimento Proximal em decorrência da sua ampla utilização, mas que as discussões apontadas por Prestes (2010; 2012) são consideradas no âmbito da compreensão teórica do conceito.
} 
paradigma de compreensão do desenvolvimento, apontando-o como um processo constante, constituído em sistemas abertos e com explícita interdependência do outro (mediador) para a promoção desse desenvolvimento. Em segundo lugar, pela relação que o autor propõe entre o desenvolvimento e a instrução escolar, colocando esta última não como causa ou consequência, mas como possível promotora do desenvolvimento. Essas ideias, mesmo que implicitamente, sustentam e justificam todo o trabalho desenvolvido nos contextos regulares escolares junto a crianças com déficit intelectual com vistas ao processo de inclusão, não apenas no âmbito das propostas pedagógicas, mas no que tange à discussão do processo de desenvolvimento dessas crianças.

Enquanto um conceito abstrato, o estudo sobre a Zona de Desenvolvimento Proximal não pode se reduzir a um comportamento específico, ou à uma atividade avaliativa única. Na perspectiva adotada neste trabalho, esse conceito é abordado ao longo do processo de interação, na análise das dinâmicas estabelecidas entre os sujeitos. Não cabe, em nenhum momento, questionar o conceito de Zona de Desenvolvimento Proximal de Vygotsky, mas, a partir dele, estudar interações de pares que possuem percursos de desenvolvimento significativamente diferentes em decorrência de um quadro de déficit intelectual e levantar questões que se espera sejam significativas para a compreensão da realidade social que permeia o desenvolvimento desses sujeitos.

Dessa forma, mediante os elementos supracitados que configuram desafios para o processo investigativo, julga-se pertinente trazer outro conjunto de constructos teóricos que possam auxiliar na análise do desenvolvimento humano: especificamente, da Rede de Significações (RossettiFerreira, Amorim, Silva \& Carvalho, 2004).

\subsubsection{Contribuições da Rede de Significações (RedSig) para a compreensão de desenvolvimento humano}

Ao longo das reflexões sobre o desenvolvimento humano, encontrou-se nos pressupostos teóricos da Rede de Significações (RedSig) (Rossetti-Ferreira, Amorim, Silva \& Carvalho, 2004) uma contribuição para a compreensão daquele fenômeno. Tal perspectiva foi elaborada a partir do estudo de processos de desenvolvimento humano em contextos institucionais de cuidados e educação na primeira infância (Rossetti-Ferreira, 2004), sendo um trabalho teórico-conceitual organizado por meio de pesquisas desenvolvidas no Centro de Investigações sobre Desenvolvimento Humano e Educação Infantil (CINDEDI).

Ela foi originalmente estruturada a partir do interlace de diferentes referenciais teóricos como: a Teoria Bioecológica do Desenvolvimento e o carácter sistêmico de compreensão das relações sociais (Bronfrenbrenner, 1996); a noção de complexidade (Morin, 1996); a teoria histórico-cultural 
(Vygotsky, 1991; 1996; Valsiner, 2000; Wallon, 2007) e a concepção dialógica (Bakhtin, 1981; 1997). Esses referenciais foram cuidadosamente colocados em diálogo e se complementam na medida em que são aproximados no intuito de compreender os processos de desenvolvimento humano, abrindo margem inclusive para contradições que antes não eram explicitadas (Rossetti-Ferreira, Amorim \& Silva, 2004).

A composição desses diferentes elementos teóricos e a maneira como esses entrelaces foram construídos, resultaram em uma forma de pensar sobre e entender os processos de desenvolvimento humano. A RedSig (Rossetti-Ferreira, Amorim, Silva \& Carvalho, 2004) é compreendida neste trabalho como um referencial teórico que auxilia tanto na compreensão sobre o processo de desenvolvimento humano, quanto na estruturação metodológica em investigações que abordam esse fenômeno. Esse referencial já vem sendo utilizado em diferentes pesquisas na área da Psicologia do Desenvolvimento (Almeida, 2014: Colus, 2012; Ferreira, 2013; Moura; 2012) tangenciando a infância, os processos interacionais e o próprio tema do desenvolvimento humano.

Enquanto referencial teórico, em linhas gerais, a RedSig parte da articulação de processos pessoais, relacionais e contextuais, embebidos em ou parte/constituintes de uma matriz sócio histórica. Esse referencial teórico contribui para explicar o processo de desenvolvimento, o qual é referido como se dando ao longo de toda a existência do indivíduo. No centro dessa perspectiva estão os processos interacionais e de significação inerentes à condição humana. É a partir desses elementos centrais que se define a vivência do indivíduo no mundo e, neste sentido, aquilo que os sujeitos experimentam nessas situadas interações é o que limita e/ou possibilita que o desenvolvimento aconteça (Rossetti-Ferreira, Amorim \& Silva, 2004).

De acordo com a RedSig, o pressuposto é de que esse desenvolvimento aconteça considerandose a rede de significações em que o indivíduo está imerso (e ao mesmo tempo constitui). Essa rede, que é estruturada por interações entre o indivíduo e outros, está imersa em elementos sócio históricos e culturais ligados entre si.

“(...) o desenvolvimento humano se dá dentro de processos complexos, imerso que está em uma malha de elementos de natureza semiótica. (...) ... as pessoas encontram-se imersas em, constituídas por e submetidas a essa malha e, a um só tempo, ativamente a constituem, contribuindo para a circunscrição dos percursos possíveis a seu próprio desenvolvimento, ao desenvolvimento de outras pessoas ao seu redor e da situação em que se encontram participando" (Rossetti-Ferreira, Amorim \& Silva, 2004. p. 23). 
Ao se trazer a teoria apresentada pela RedSig para as discussões sobre o desenvolvimento da criança com déficit intelectual dentro do contexto da educação infantil e, mais, sobre as interações entre pares no estabelecimento de Zonas de Desenvolvimento Proximal, identificam-se relevantes contribuições para se pensar sobre e investigar o fenômeno em questão. Neste sentido, três elementos desse referencial teórico são especialmente relevantes para a reflexão proposta: (1) os processos interacionais como constituidores do desenvolvimento humano em campos interativos dialógicos; (2) a significação do mundo e as produções de sentido compartilhado como elemento constituidor do sujeito, e; (3) o entendimento da possibilidade de múltiplas trajetórias para o desenvolvimento humano.

As interações são entendidas neste referencial como elementos centrais e fundantes no processo de desenvolvimento, sendo através daquelas, nos seus diversos campos (contextos) que ocorre a constituição do sujeito. As contribuições neste quesito emergem a partir da discussão de que esses processos se dão em campos interacionais dialógicos, ou seja, considera-se que o sujeito estabelece, desde o nascimento, inúmeras ações partilhadas e interdependentes (inter-ações) em diferentes cenários ou campos interativos. Ao mesmo tempo, esses campos interativos são compartilhados e, consequentemente, interferem uns nos outros; o sujeito é constituído pela confluência de todos esses processos interativos distintos, revelando uma dinâmica sistêmica (Bronfenbrenner, 1996).

No caso da criança com déficit intelectual na educação infantil, por exemplo, entende-se que o desenvolvimento dessa criança e sua constituição enquanto pessoa se dão pela confluência dos seus processos interacionais com todos os seus colegas de sala, seus professores, outros funcionários da escola, seus familiares, o próprio espaço e etc. Ao mesmo tempo, dialogicamente, esses sujeitos em interação com a criança com déficit intelectual que vêm para esse campo interativo específico (a escola) também são constituídos por outros elementos (concepções sobre deficiência, construções culturais, influências familiares, experiências prévias e etc.) e também se constituem na relação e experiências com a criança com déficit intelectual.

A quantidade e a diversidade de possibilidades interacionais são, assim, inúmeras. Dessa variedade, constitui-se o diálogo entre os contraditórios e os complementares da experiência humana, o que vai (re)definindo também as inúmeras condições de ser humano.

"Múltiplos papéis/ contra-papéis e posicionamentos são possíveis de serem apreendidos e transformados por cada pessoa, ao longo de seu desenvolvimento, a partir das múltiplas e complexas experiências pessoais, em contextos variados (...)" (Rossetti-Ferreira, Amorim \& Silva, 2004. p. 25) 
O que se entende então é que o que se obtêm desses encontros é uma rede de conexões ou redes de significações que contribuem para constituir o sujeito. Embora a noção de rede por si só não traga nenhuma definição do desenvolvimento, ela permite que se pense as interações humanas dentro desses campos dialógicos enquanto circunscritores desse desenvolvimento.

"Nas interações, espaço onde ocorre a negociação dos circunscritores -, a pessoa constrói a concepção acerca do mundo e de si própria. É nas relações situadas, em cada momento do fluxo de ações das pessoas em interação (concretas ou imaginárias), que os circunscritores se compõem, atualizando modos de relacionamentos, valores e concepções de um determinado grupo cultural, assim como significados de experiências do tempo vivido e expectativas" (Silva, Rossetti-Ferreira \& Carvalho, 2004. p. 87)

Essa premissa auxilia a reflexão sobre o próprio contexto escolar para a criança com déficit intelectual, pois permite que se pense nas diferentes possibilidades de interação e de constituição de sujeito dessa criança. Auxilia ainda a pensar que não basta analisar as unidades interativas entre os sujeitos, mas sim os diversos elementos que tangenciam o momento da interação, tais como: concepções sobre déficit intelectual; crenças e pré-conceitos sobre o desenvolvimento da criança com déficit; experiências anteriores; projetos pedagógicos, dentre outros.

Ao mesmo tempo, fomenta a ideia do quão importante é a multiplicidade de interações para o desenvolvimento humano, uma vez que a partir de cada interação novos processos dialógicos são colocados em ação. Essa multiplicidade amplia as possibilidades de se pensar em como esse desenvolvimento pode (ou não) acontecer.

Contudo, a reflexão sobre a relevância das interações por si só não é suficiente, tampouco se restringe a isso a teoria da Rede de Significações. Para continuar o diálogo proposto, o segundo ponto de destaque é o processo de significação, ou ainda, o processo de construção de sentidos em cenários compartilhados dentro dessa rede em que o desenvolvimento se dá. Para essa discussão, cabe a ressalva do que é que está se chamando de significação.

Smolka (2004), ao explanar sobre o processo de significação, utiliza uma citação de Vygotsky (1995, p. 84) que o caracteriza como "a criação e ao uso de signos, é a atividade mais geral e fundamental do ser humano, a que diferencia em primeiro lugar o homem dos animais do ponto de vista psicológico”. Esse processo de significação é, para Vygotsky, o que garante o desenvolvimento humano, sendo a aquisição da linguagem (enquanto sistema de signos linguísticos) um marco para 
esse desenvolvimento (Vygotsky, 1995). Trata-se da base do processo de interiorização que permite as construções das funções mentais superiores e, portanto, elemento central para o desenvolvimento. Sobre isso, Smolka (2004) afirma que:

"É impossível ao homem não significar. A significação faz parte da atividade humana. (...) é a possibilidade de significação, não apenas como capacidade intrinsecamente humana, mas como condição mesmo daquilo que é especificamente humano, que se encontra aqui colocado como objeto de consideração" (Smolka, 2004. p.35).

Quando posto isto em reflexão a partir do problema de estudo levantado, uma das grandes questões gira em torno do como ocorre o processo de significação para a criança com déficit intelectual na educação infantil, haja vista que um dos elementos mais comuns nesse sujeito é a ausência ou a dificuldade da verbalização pelo atraso ou limitação na aquisição da linguagem. Se esse processo que é, segundo Vygotsky (1996), a criação e o uso de signos, sendo estes "o próprio meio/modo de articulação das funções em nós mesmos, e poderemos demonstrar que sem esse signo o cérebro e suas conexões iniciais não poderiam se transformar nas complexas relações, o que ocorre graças a linguagem” (p.114), como fica a significação por aquele sujeito que tem limitações acentuadas na sua capacidade comunicativa e de linguagem verbal? Se a significação é então o elemento que garante que nessas interações haja desenvolvimento, qual seria o olhar que o pesquisador deveria ter para com a análise desses processos interativos nesta situação?

No mesmo Vygotsky, porém de outro momento histórico de sua trajetória ${ }^{11}$, é apontado que as mudanças periódicas na atividade cognitiva que ocorrem durante a infância estão necessariamente associadas com mudanças profundas no aspecto motivacional-emocional da personalidade da criança. A busca pela gênese das emoções traz à tona o diálogo com o conceito de vivência (Vygotsky, 1999) que vai, na visão das reflexões neste trabalho, particularmente privilegiar o papel das sensações, emoções e sentimentos na significação, abrindo margem para se refletir sobre o corpo nesse processo.

Furlan (2004) contribui para a discussão com a reflexão do lugar da corporeidade na medida em que explicita a corporeidade como expressão linguística, afirmando que "não se trata, pois, de negar a sua (linguística) importância na formação do sentido vivido, mas de forçar sua abertura aos registros de sentido do corpo que não se reduzem a esses organizados linguisticamente" (p.52). O autor abre espaço para que os processos de significação perpassem o uso do corpo e para que esse corpo possa ser instrumento de análise das produções de sentido, uma vez que,

\footnotetext{
${ }^{11}$ Nos referimos aqui o momento da trajetória de Vygotsky pós 1932. Nesse período, o autor teve bastante influência da Psicologia Alemã Gestalt.
} 
“(...) nem todo sentido de mundo se reduz apenas à sua forma linguística (...) são sentidos que fazem parte da situação do corpo no mundo, da humanidade, de forma geral ainda que se encontrem sempre assumidos por meio de uma forma cultural específica. (...) Trata-se, pois, de uma rede de intencionalidades corpóreas que representam o modo como o corpo se relaciona com o mundo, que mesmo sendo sempre assumido numa forma linguística, pertence a uma ordem específica da percepção" (Furlan, p. 53).

González-Rey (2004b; 2002), que corrobora a importância da dimensão corporal, chama a atenção para a forma pela qual se dá a participação do mundo cultural no sentido vivido, apontando que "não é legítimo separar a emocionalidade associada ao corpo da emocionalidade produzida na cultura; uma perpassa a outra integrando a dimensão do sentido" (González-Rey, 2004b. p.61)

Reddy (2012), ao tratar sobre interações com bebês, afirma que desde muito cedo o bebê humano estabelece com seus interlocutores processos de negociação e construção de significado conjunto. Esses processos são desencadeados pelas expressões corporais e pelo engajamento na atividade conjunta, quando a linguagem ainda não perpassa a fala e a sistematização da língua. Seus estudos (Reddy, 2012; 2015; Reddy \& Mireault, 2015) apontam que, ao contrário do que se postula, o bebê humano, mesmo sem a aquisição da linguagem, é ativo e propiciador de negociações que estabelecem formas específicas de interação desde muito cedo, exercendo papel ativo e construtor no processo de significação. Tais ideias corroboram com a perspectiva aqui construída e ampliam as possibilidades de reflexão e de análise desse processo de significação conjunta da criança com déficit intelectual.

Da mesma forma, em amplo estudo sobre linguagem, comunicação e significação em bebês, Amorim (2013) verificou uma enorme capacidade interativa do bebê desde muito cedo. Indo além da literatura vigente que privilegia a mãe como parceira central nesta fase da vida e imputa aos infantes uma condição de incapacidade comunicativa, os dados de sua pesquisa mostram situações de interação de bebês, onde os mesmos utilizam-se de recursos comunicativos complexos e diversos, próprios da sua idade, no sentido de estabelecerem negociações e construírem, na relação com o outro, esse processo comunicativo. A contribuição presente em Amorim (2013) reside na apresentação de dados empíricos que evidenciam que essas habilidades não são herdadas, mas construídas socialmente na relação com o outro e que os gestos, as vocalizações e a forma como o processo interacional acontece configuram uma complexa dinâmica de construção de significados. 
Essas reflexões oferecem subsídios para que o desenvolvimento proveniente do processo de produções de sentido nas atividades conjuntas entre crianças com déficit intelectual e demais crianças sem déficit possa ser analisado, em primeiro lugar, por elementos que não são circunscritos apenas pela linguagem verbal. E, em segundo, por meio de uma visão dialógica da interação, pois, se a partir do que pressupõe a RedSig, as interações são circunscritoras no desenvolvimento e dialéticas no seu processo, pode-se pensar que não seja somente a criança com déficit intelectual que aprende (e portanto, se desenvolve) na interação com as demais crianças. O contrário, mesmo que caracterizada por uma interação com um parceiro "menos capaz"12 também acontece, aí, ampliando o que postula Vygotsky (2007) sobre a Zona de Desenvolvimento Proximal.

Por fim, entende-se que outro elemento importante que a RedSig traz para a discussão do tema proposto é o pressuposto de que, para o ser humano, não existe um único caminho para o desenvolvimento. Ao contrário, são inúmeras as possibilidades de configuração das redes de significações de cada sujeito que oportunizam a ele também inúmeras possibilidades de constituição e, consequentemente, de desenvolvimento (Rossetti-Ferreira, Amorim \& Silva, 2004; Amorim, 2013). A RedSig abre maior espaço para a vivência, evidenciando que, no momento de ação (com)partilhada, processos de significação estão acontecendo de modo que, mesmo os sujeitos compartilhando uma dada experiência, os sentidos produzidos são singulares e, consequentemente, a sua vivência.

Pensar na multiplicidade de trajetórias de desenvolvimento é condição imprescindível para se investigar o processo de desenvolvimento da criança com déficit intelectual, uma vez que, para esse sujeito, condições organicamente impostas trarão por si só outros jeitos de se estabelecer interações com os outros e, consequentemente, de realizar sua vivência no mundo.

Em suma, considera-se que:

“A configuração da rede disponibiliza um conjunto de significados, os quais se constituem como mediadores de cursos prováveis de ação do conjunto das pessoas participantes de uma situação. Esses significados canalizam as ações/ emoções/ concepções em determinadas direções, mais do que em outras; promovem certas práticas sociais; delimitam certas zonas de possibilidades de atuação dos parceiros em interação. Portanto, a configuração atua como impulsionadora para determinadas direções e aquisições, ao mesmo

\footnotetext{
12 Referindo-se ao termo diretamente oposto do postulado por Vygotsky (2007) quando se refere a Zona de Desenvolvimento Proximal: “(...) distância entre o nível de desenvolvimento real, que se determina através da solução independente de problemas, e o nível de desenvolvimento potencial, determinado através da solução de problemas sob orientação de um adulto ou em colaboração com companheiros mais capazes" (p. 97)
} 
tempo em que distancia ou, mesmo, impede ou interdita outra" (Rossetti-Ferreira, Amorim \& Silva, 2004. p. 29).

Mas há que se explorar ainda como esses elementos se configuram, em que medida eles acontecem, de que forma vão se constituindo. A rede nos auxilia a pensar sobretudo o que está envolvido no processo, mas não necessariamente responde à questão do como todos esses elementos vão se constituindo. Para a análise do desenvolvimento da criança com déficit intelectual, que está de forma dominante compreendida dentro apenas de uma perspectiva de limitações e impossibilidades, pensar na hierarquia do processo faz total diferença para a forma de intervenção na atuação junto a essa criança e na desconstrução da ideia de um desenvolvimento fragmentado ou limitado.

Dessa forma, analisando o contexto em que o processo investigativo se dá e considerando o princípio da natureza social do desenvolvimento humano que norteia a teoria histórico-cultural, entende-se que as interações (enquanto recorte empírico), os recursos para o estabelecimento das mesmas e os produtos dessas relações (a cultura compartilhada, transformada, produzida) sejam componentes centrais na discussão do desenvolvimento da criança com déficit intelectual na préescola.

\subsection{Os processos interacionais, a comunicação e a construção da cultura na infância}

A definição conceitual de interação, comunicação e cultura adotadas neste estudo, configurase como importante tripé teórico, pois orientará o leitor para a compreensão do ponto de vista defendido na tese proposta. O esforço neste momento é de explicitar claramente a relação entre eles, a partir dos pressupostos da Teoria Histórico Cultural.

Partindo-se do pressuposto de que o desenvolvimento humano se dá eminentemente com o Outro no processo de interação em diferentes contextos sociais e ao longo do processo de interiorização da cultura, depara-se com a necessidade de se analisar as relações construídas entre os sujeitos e, mais especificamente, buscar entender como se dá o processo de interação para posteriormente, conseguir identificar o seu elo desenvolvimental (foco deste estudo). Neste processo, a comunicação enquanto processo de trocalconstrução de significado (Pedrosa \& Carvalho, 2006) toma um lugar central na discussão e o reconhecimento do papel ativo da criança na construção de cultura na infância (Leinonen \& Sintonen, 2014), um pressuposto sine qua non para qualquer avanço nas análises desse tema.

Inicia-se a reflexão pelo conceito de interação. Mas, o que é interação? Como identificá-la? Como analisá-la, haja vista que esse também é um fenômeno cujos delineamentos empíricos são complexos? 
$\mathrm{Na}$ ânsia de se definir tal constructo, encontram-se na literatura diferentes propostas ou perspectivas de discussão sobre a interação, muitas delas decorrentes do trabalho de Hinde (1976). Mas, em particular, traz-se aqui para a discussão as contribuições de Carvalho, Império-Hamburgo e Pedrosa (1996) que, objetivando elaborar uma reflexão sobre o tema, discutem-no a partir da busca pela definição de cada um dos elementos circunscritores do cenário interativo. Adota-se neste trabalho os conceitos de: campo de interações; regulaçãolcorregulação e interação social.

Em linhas gerais, a abordagem sobre a interação trazida por Carvalho, Império-Hamburgo e Pedrosa (1996) conceitua os elementos, auxiliando na compreensão da função constitutiva da interação para o ser humano e, ao mesmo tempo, mostra como esses elementos podem ser identificados por meio de comportamentos observáveis. Através de uma analogia com um sistema físico de movimento de partículas, as autoras definem campo de interação como o ambiente onde torna-se possível que a interação exista. O campo de interação é composto por todos os elementos (espaço físico, tempo, sujeitos, objetos, ações e etc.) que participam ou constituem, através de um movimento irregular e incessante, o cenário no momento da interação. Para as autoras, o campo é 'definido pela natureza das partes que interagem, ao mesmo tempo que as constitui' (Carvalho, Império-Hamburger \& Pedrosa, 1996. p. 4)

O conceito de interação é definido por "um potencial de regulação entre componentes do campo social" (Carvalho, Império-Hamburgo e Pedrosa, 1996. p. 4). O termo potencial presente nessa conceituação amplia o impacto e a possibilidade de análise do recorte interativo, uma vez que remete não só a uma ação presente como a elementos do passado e possibilidades de ações futuras. Para compreender melhor essa definição é preciso levar em consideração, ainda, que o potencial se refere ao trânsito de informações (construçãolcompartilhamento de significado) entre os sujeitos que, por sua vez, compõem um campo social.

$\mathrm{Na}$ perspectiva deste trabalho, a maior contribuição das autoras para a discussão sobre a temática está na ideia de que a interação é um fator estritamente social, uma vez que se regula pela 'presença ou pela ação de um elemento co-específico da espécie - outro humano, mesmo que um deles não saiba que regula o outro' (Carvalho, Império-Hamburger \& Pedrosa, 1996, p. 7). A regulação e a corregulação do comportamento torna-se assim, o elemento central da identificação do processo de interação, materializado em todo e qualquer tipo de transformação manifestada em ação. Dentro da análise da interação, que é assim demarcada pelo que o outro (sua presença/ausência, suas ações, falas, expressões) suscita no parceiro dentro do campo interativo, é por meio da corregulação de comportamento que as sínteses ou condensações de informação são efetivadas. A partir dessas sínteses, também chamadas de correlações, emerge o princípio da sociabilidade, que é constitutivo do fenômeno da cultura, a persistência de significado (Carvalho \& Rubiano, 2004, p. 173) 
Dentro desse já complexo debate conceitual e tendo como referência o trânsito de informações como um elemento componente do campo social, chama-se a atenção para os processos comunicativos e a forma como esses circunscrevem e explicitam a interação, possibilitando sua análise.

\section{A comunicação e a compreensão do processo de desenvolvimento}

O uso do termo comunicação, ao invés de linguagem, e a sua diferenciação na relação com o conceito de interação são propositais para explicitar o raciocínio adotado na análise do fenômeno em estudo. $\mathrm{Na}$ discussão conceitual sobre o termo linguagem, dentro do prisma psicológico da perspectiva Histórico-Cultural, existem diversas ênfases sobre o que poderia ser considerado por essa terminologia (Smolka, 1995). Parte significativa do trabalho de Vygotsky dentro dessa temática ocupa-se da análise da aquisição da fala como processo e condição inerente para o desenvolvimento das funções mentais superiores (Vygotsky, 2007; 2012b). Fruto desse intenso trabalho, o universo das palavras, em especial o processo de formação dos conceitos, foi a base para futuros trabalhos investigativos no campo da linguagem como instrumento que constitui o aparato cognitivo humano (Van Der Veer \& Valsiner, 2014).

Vygotsky (2007; 2012b) não explicita claramente a diferenciação entre os conceitos com os quais formula as suas argumentações, deixando margem para interpretações contraditórias. A ênfase dada na fala (como a expressão do signolpalavra que carrega um sentido e possibilita a construção de significados) e sua relação com o desenvolvimento das funções mentais superiores, vai definir na perspectiva Histórico-Cultural um conceito de linguagem que havia sido prioritariamente marcado por sua função instrumental. Segundo Kozulin (1990; 2000; 2003), mesmo que através de uma análise ampla dos trabalhos de Vygotsky se possa perceber que o autor tinha preocupações que iam muito além da função instrumental da linguagem (recursos linguísticos), a associação entre ‘linguagem' e 'fala' demarca suas proposições e é dessa forma que muitos teóricos vêm empregando o termo em seus trabalhos.

Tal conceito, embora tenha trazido inovações teórico-metodológicas relevantes e imprescindíveis para o avanço do pensamento e da investigação na Psicologia do Desenvolvimento, perpetuou-se cristalizado e foi interpretado como a ideia dicotômica de que é a fala o elemento que representa a aquisição da linguagem e, consequentemente, é a expressão verbal o elemento chave e funcional para a análise do desenvolvimento do pensamento humano.

Smolka (1995) chama atenção para a necessidade de maior preciosismo na definição conceitual e utilização do termo. A autora defende que as elaborações de Vygotsky vão além da questão instrumental, apontando para a função constitutiva da linguagem sendo, em sua opinião, essa 
a maior contribuição do autor. Nesse sentido, a linguagem não seria apenas instrumento, tampouco modo ou ação, mas seria o próprio processo de constituição (caráter produtivo da linguagem) social do homem.

Contudo, mesmo dentro dessa compreensão ampla do conceito de linguagem, depara-se com um nó teórico-metodológico: a ênfase na associação conceitual entre linguagem e fala, que foi, dentro da perspectiva histórico-cultural, cristalizada. Seria a verbalização a única forma de compartilhamento de sentido? Seria a ação oral constituída na fala, na expressão da palavra, a única forma de construir significado comlatravés do Outro, de transformar o interpsíquico em intrapsíquico? Esses são questionamentos que levam à opção pelo uso do termo comunicação, adotando a epistemologia da teoria histórico-cultural para analisá-lo.

Considera-se como comunicação a ação (e que, portanto, poderá ser manifestada em comportamento gestual, em expressões faciais(corporais ou através da verbalização) cujo resultado pode vir a acarretar no compartilhamentolconstrução de significados entre o sujeito e o Outro em um dado campo interativo. Comunicação é, portanto, entendida enquanto um processo tal que pode tomar parte da dinâmica interacional (unidade de análise deste estudo) e, consequentemente, do desenvolvimento humano (objetivo do trabalho). Tomando como referência as discussões apresentadas por Smolka (1995) sobre a função constitutiva da linguagem, adota-se para a formulação do conceito de comunicação neste estudo, o princípio da função constitutiva desse processo, onde conhecimentos e sentidos são produzidos por ele.

Estudos no campo da Psicologia do Desenvolvimento com enfoque em crianças pequenas (Reddy \& Trevarthen, 2004; Amorim, 2012; Amorim, Anjos \& Rossetti-Ferreira, 2012; Amorim, Costa, Rodrigues, Moura \& Ferreira, 2012; Rossetti-Ferreira \& Amorim, 2008; Trevarthen \& Malloch, 2002), desenvolvem as possibilidades de ampliação desse conceito, traçando caminhos mais pertinentes para a discussão proposta nesse trabalho. Segundo Reddy (2010), a maioria dos trabalhos em Psicologia do Desenvolvimento são cépticos em relação a possibilidade de uma genuína comunicação quando o outro não tem ainda o aparato linguístico para expressar suas ideias. Os estudos concentram-se na linguagem falada ou na comunicação de informação (conteúdos com significado específico fora do indivíduo), e consideram quaisquer outras trocas como insignificantes para a o entendimento do fenômeno. Entretanto, desde a década de noventa do século passado, autores que trabalham com foco em estudos sobre o desenvolvimento humano de bebês (Trevarthen, 1979; 1999; Bruner, 1973; Tomasello \& Farrar, 1986; Tomasello, Kruger \& Ratner, 1993; Amorim \& Rossetti-Ferreira, 2008a) chamam a atenção para a ampliação da noção de comunicação, sugerindo processos diversificados para a construção e entendimento do que seja linguagem. 
A ideia central nesses estudos considera a linguagem como produto histórico, constituída e constituidora do sujeito, mas que não seja limitada pela apresentação exclusiva da fala (Amorim, 2012). Tais estudos apontaram para a genuína capacidade humana de comunicar-se e construir significações com o Outro por meio de processos de compartilhamento que não se sustentam exclusivamente pela fala (expressão da palavra), mas por gestos, expressões faciais elou vocalizações, a que alguns autores definem como proto-linguagem (Trevarthen, 1999).

Para Trevarthen (1999), a linguagem é inventada na experiência comum, uma ferramenta fabricada da fantasia humana coletiva, a qual pode ser ensinada a um indivíduo ou estudada enquanto algo específico, mas aprendida pelo compartilhamento. Para este autor, ao contrário da ideia instrumental da linguagem, essa é constitutiva do ser humano e é através da linguagem que os elementos culturais são expressos, transmitidos e construídos. Mas a linguagem não se limita à fala e por si só não garante o processo de compartilhamento.

Em crianças pequenas que ainda não dominam a linguagem verbal, as repetições da ação sinalizam que elas estão juntas com o parceiro em torno do mesmo objeto, da mesma atividade, das mesmas questões (Pedrosa \& Carvalho, 1995; Pedrosa, 1996; Nadel \& Baudonnière, 1981). Trevarthen e Aitken (2001) vão discutir o quão importante são os processos de comunicação que não dependem da fala, mas que preparam o indivíduo para a utilização da mesma. Em seus estudos empíricos, Trevarthen e Aitken constatam as similaridades nos ritmos, nas entonações e nuances do balbuciar do bebê em relação à fala dos pais, mas são os gestos, as expressões faciais e o tempo definidos no processo comunicativo de determinadas interações que suporta a análise da intencionalidade das crianças no processo. Se a linguagem "vive nas bordas entre o seu próprio contexto e o do outro" (Amorim \& Rossetti-Ferreira, 2008b, p. 238), se ela deve ser analisada dentro e a partir da intencionalidade que a gera, e se, nas infinitas possibilidades de significação é viável diferentes arranjos dos signos disponíveis, a análise do processo comunicativo entre as crianças, com e sem recursos linguísticos, deve considerar outras manifestações que não somente as verbais como a fala.

Dessa forma, o uso do termo comunicação, neste estudo, justifica-se porque representa o ato que resulta no compartilhamento de sentidos ou a (re)(des)(co)construção de significados a partir da interação com o outro. É por meio da comunicação, enquanto processo dialógico, que não necessariamente perpassa pela fala, mas está impregnada por ela, e que possibilita o olhar para a construção de outros modos de compartilhamento de significados, que se encontrou maior pertinência na forma de expressar o que se propõe analisar neste estudo.

O conceito de 'comunicação' possibilita, assim, maior liberdade na análise das expressões dos sujeitos nesse trabalho; melhor expressa o significado do processo estudado e abre mais espaço para 
novas explanações teóricas que tragam uma forma inédita de entender a(s) teia(s) que tecem o desenvolvimento humano. A comunicação, enquanto ação, nos possibilita identificar processos de apropriação e construção de cultura.

\section{A construção de cultura na infância}

Dentro dessa perspectiva e com particular atenção ao contexto da educação infantil, os processos interacionais de pares vêm se tornando um tema pesquisado mundialmente. O investimento em pesquisas com crianças pequenas, em particular na investigação do processo de construção cultural na primeira infância, justifica-se pela compreensão de que o desenvolvimento e a autonomia estejam diretamente relacionados ao processo de apropriação de elementos culturais, e que seja nesta etapa da vida que esse processo começa a ficar mais intenso (Corsaro, 2003; 2005; 2009; Kronqvist, 1998; Rodd, 1998; Rutanen, 2011; 2014; Sheridan, 2011). Tal pensamento é oriundo do reconhecimento de que os aspectos sociais são a gênese do processo de desenvolvimento humano, pressuposto revolucionário da teoria histórico-cultural que embasa esse desenvolvimento na aquisição de cultura (Sant'Ana, 2007).

O termo cultura, entretanto, traz significados diversos, carrega uma história e um conjunto de construções próprias da palavra e de seu uso em diferentes contextos, como aponta Amorim (2002). Dessa forma, longe de tecer extensa discussão sobre o que pode ou não ser considerado cultura, ressalta-se apenas que, a depender dos interlocutores e de seus interesses, a utilização do conceito terá um enfoque diferente, o que por si só explicita as bases teóricas sobre as quais se entende o fenômeno em estudo.

Neste trabalho, o termo cultura (conceito esse pulverizado nas obras de Vygotsky $(1928)^{13}$ relaciona-se diretamente com o produto da convivência em grupos originado ao longo da história da humanidade (Van Der Veer \& Valsiner; 2014). Concorda-se com a necessidade de ampliar o termo cultura, portanto, consciente das críticas com relação ao sentido adotado por Vygotsky para este conceito, que o limita à expressão das transmissões culturais diretamente ligadas à linguagem, sem explicação dos processos de inovação ou daqueles não linguísticos (Van Der Veer, 1996). Nessa ampliação, cabe trazer à baila também outras formas de construção de significações envolvidas nas regulações de ação.

A cultura é, portanto, aqui concebida, como o conjunto de signos e instrumentos acumulados historicamente que possibilitam, teoricamente, ao ser humano a constante (re)significação do mundo ao seu entorno, dependente ou independentemente da forma de transmissão adotada (fala, gestos,

\footnotetext{
13 Vygotsky, L. S. (1928) Defektologija i uchenie o razvitii i vospitanii nenormal'nogo rebenka. In Vygotsky, L. S. Sobranie sochinenij. Tom 5. Osnovy defektologii. Moscou, Peddagogika, pp. 325-326.
} 
contatos diversos). Falar em construção de cultura na infância é, então, referir-se ao processo pelo qual a participação da criança é reconhecida como capaz de utilizar esse aparato de signos e instrumentos para significar o mundo que a cerca, ao mesmo tempo interferir, criar ou (re)significar esse contexto para o outro (Corsaro, 2003).

Segundo Pino (2000, 2005), a cultura caracteriza-se pela natureza transformada pelo homem, materializada em todas as atividades e produções humanas. Nos textos de Vygotsky, a cultura aparece como a ferramenta que é a base de todo o desenvolvimento humano, uma vez que, para o autor, o desenvolvimento cultural é caracterizado como um processo de transformação de um ser biológico em um ser cultural (Pino, 2005).

Caminhando adiante e seguindo a mesma linha de pensamento, entendemos que o desenvolvimento acontece na medida em que o indivíduo se apropria dessa cultura e, através do desenvolvimento das funções mentais superiores, estabelece processos diversos de significação de mundo de forma dialética (Vygotsky, 2007; Rego, 1999; González-Rey, 2012). Nesse sentido, temse que reconhecer também o papel ativo da criança no seu processo de desenvolvimento e, por analogia, no desenvolvimento do outro que a cerca.

Majoritariamente, no entanto, na discussão desse processo, pesquisas e textos teóricos (Facci, 2004; Maluf \& Mozzer, 2000) reportam-se ao adulto como pessoa central mediadora; ou, em alguns casos, na figura de uma criança mais capaz, mais velha ou que tenha um nível de conhecimento e vivência superior ao da outra criança.

Entretanto, as experiências e observações provenientes de contextos educacionais, no diálogo com relatos de pesquisas realizadas sobre a capacidade de crianças pequenas se regularem a partir do outro (Corsaro \& Molinari, 1990; Verba, 1994; Schilling \& Clifton, 1998; Império-Hamburger, Carvalho \& Pedrosa, 1998; Carvalho, Branco, Pedrosa \& Gil, 2002; Guralnick, 2002; Pedrosa \& Carvalho, 2009; Costa, 2012; Rodrigues, 2011; Scorsolini-Comin \& Amorim, 2010; Amorim [et al] 2012; Costa \& Amorim, 2015), além de trabalhos voltados a compreender os processos interacionais de crianças em contextos institucionais (Souza \& Batista, 2008; Rutanen, 2009; Colaço, Pereira, Neto, Chaves \& Santiago de Sá, 2007; Moura, 2012; Roriz, 2005; Amorim, Anjos \& Rossetti-Ferreira, 2012; Moura \& Amorim, 2013) levam a crer que haja também uma contribuição para o desenvolvimento na interação entre pares de mesma idade, mesmo com parceiros igualmente ou menos experientes.

Por meio das funções reguladoras do comportamento e da construção coletiva de significados no contexto social compartilhado, as crianças desempenhariam um papel de (co)construtoras de cultura e, consequentemente, propiciadoras de processos de desenvolvimento. Os valores e comportamentos próprios do seu tempo são apropriados pelas crianças, significados a partir das 
vivências individuais e compartilhados coletivamente; são parte integrante das suas vidas, do seu desenvolvimento.

Ainda sobre as possibilidades de interação na infância, Lewis e Takahashi (2005) discorrem sobre os fatores que interferem no desenvolvimento humano a partir da ótica das relações estabelecidas em rede social. Os autores apresentam um modelo de relacionamento em redes sociais o qual se contrapõe ao modelo clássico epigenético, que teoriza que a primeira e principal relação estabelecida pelo ser humano é necessariamente aquela entre a mãe e a criança e, a partir dela, são possibilitadas outras relações a depender da qualidade dessa inicial. O modelo de Redes Sociais sustenta que haja várias relações coexistentes nesse período inicial de vida, que a relação entre mãecriança, embora importante e que acarrete em interferências nas demais, não é a única e pode nem vir a ser a central a determinar o desenvolvimento do indivíduo.

No modelo proposto por Lewis e Takahashi (2005), além de ser possível encontrar relações de apego com outros membros da família como, por exemplo, o pai, os autores ponderam que há uma rede de relações entre os pares de idade, cuja função é fundamental para o desenvolvimento de habilidades sociais e para a construção de elementos significantes da cultura. Os autores afirmam que, em decorrência da proximidade de idade, alguns elementos são compartilhados entre as crianças e isso possibilita um processo de aprendizagem mais efetivo. O repetido contato entre pares favorece à criança a descoberta de contingentes entre as suas próprias ações e as ações de outras e seria através dessa descoberta que os repertórios sociais internos seriam desenvolvidos, o que por sua vez seria um fator preponderante para o restante das relações estabelecidas na vida adulta (Lewis e Rosenblum, 1975).

Dessa forma, a concepção de que a criança é agente ativo no processo de construção de cultura na infância, de que ela é um sujeito nesse existir no mundo (Spyrou, 2011) e a defesa pela compreensão de desenvolvimento humano baseado nas perspectivas teóricas até aqui apresentadas, resultam para o presente estudo a concepção de que a criança será também participativa e constituidora do seu próprio desenvolvimento e do outro. Além disso, ao se entender que existe a construção cultural pela criança, vislumbra-se que resida neste elemento um relevante e poderoso instrumento para construir transformações sociais, a exemplo do processo de inclusão educacional de pessoas com deficiência.

Entretanto, para aprofundarmos as discussões sobre o papel da criança no processo de inclusão social é necessário entendermos como historicamente tem sido entendido o desenvolvimento da criança com deficiência (no caso particular desse estudo, a deficiência intelectual). Muitas têm sido as concepções e seus desdobramentos na história, revelando elementos que, muitas vezes, posicionam 
o desenvolvimento da criança com déficit intelectual como refém dos aspectos biológicos, desconsiderando a complexidade da gênese sociocultural humana.

\subsection{0 desenvolvimento da criança com déficit intelectual}

O trabalho enfocando o déficit intelectual dentro da perspectiva teórica apresentada traz à baila a necessidade de discussão conceitual do referido fenômeno. Embora não seja objetivo dissertar sobre as origens, terminologias, defesas teóricas e modelos de atendimento como centro desta pesquisa, neste subcapítulo julga-se pertinente apresentar, mesmo que sucintamente, como é mais usualmente considerado o déficit intelectual no âmbito conceitual, teórico e prático, indicando como esse conjunto de discussões embasa o olhar específico para os processos interacionais aqui investigados.

\subsubsection{Os conceitos de deficiência e suas transformações ao longo do tempo}

Iniciando pela apresentação do termo/conceito de déficit intelectual, destaca-se que, ao longo do tempo, no Brasil, aquele tem se apresentado de formas diferentes, tais como: idiotia, debilidade mental, retardo mental, deficiência mental, deficiência cognitiva/déficit cognitivo até chegar ao conceito de deficiência intelectual/déficit intelectual (Pletsch, 2010; Dechichi, 2001; Silva, 2009). Em outros países europeus ou nos Estados Unidos, usam-se termos tais como mental retardation, mentally handicap, mentally disable, até se utilizar o termo Intellectual disability (AAIDD, 2010; Keith \& Keith, 2013).

O uso específico de determinada nomenclatura não se restringe a uma questão linguística, mas revela uma concepção teórica que está diretamente relacionada a certas condições sociais e políticas que demarcam a discussão do fenômeno da deficiência no ser humano. Dessa forma, parâmetros e comportamentos que orientam a conceituação de déficit/deficiência apresentam transitoriedade ao longo do tempo (Keith \& Keith, 2013).

Atualmente, o termo déficit intelectual é considerado pela American Association on Intellectual and Development Disabilities - AAIDD - o que melhor traduz a compreensão de que essa condição humana se refere a um aspecto específico e circunstanciado do desenvolvimento humano. $\mathrm{O}$ termo revela a compreensão de que o déficit é determinado na relação do sujeito com o mundo que o cerca, não se tratando nem de um fenômeno puramente orgânico, pensamento sustentado por um modelo médico (Shakespeare \& Watson, 2001), tampouco em um resultado exclusivo das relações sociais, pensamento sustentado por um modelo social (Oliver, 1996; Silvers, Wasserman \& Mahowald, 1998; Keith \& Keith, 2013).

Para corroborar a argumentação acima, inúmeros são os trabalhos na última década que se debruçaram no sentido de discutir o processo histórico conceitual e relacional do termo ao longo das 
transformações sociais (Pessotti, 1984; Mazzotta, 1987; Fonseca, 1995; Januzzi, 2004; Marques, 2001; Pletsch, 2010; Almeida, 2004; Anache \& Mitjáns, 2007; Carvalho \& Maciel, 2003; Ferri \& Hostins, 2006; Ferreira \& Glat, 2003). Por esses estudos é possível acompanhar como os processos de transformação social e determinadas estruturas sociais influenciam ou direcionam a forma como se compreende e se relaciona tanto com o próprio conceito quanto com a pessoa com déficit intelectual.

Segundo Pessotti (1984), Sazzaki (1997) e Mendes (2010), identificam-se dois grandes fatores que impulsionaram as transformações na forma como a deficiência (física, mental, sensorial e outras) foi sendo construída ao longo da história: o pensamento religioso cristão e a evolução dos estudos científicos. Se por um lado a propagação do pensamento cristão (século XVI) contribuiu para o fim de práticas de extermínio da pessoa com deficiência, por outro lado há o início de um processo de institucionalização desse indivíduo (Pessotti, 1984; Sazzaki, 2007). Essas concepções determinaram as formas como esses sujeitos foram inseridos (ou excluídos) na sociedade ao longo de décadas; o olhar para com o indivíduo com deficiência perpassava a pena ou a rejeição (Pessotti, 1984).

A institucionalização do século XIX e metade do século XX foi legitimada socialmente quando o referencial ideológico cristão começa a perder força nas práticas sociais, principalmente em decorrência das transformações econômicas pós-revolução industrial e quando os atendimentos (tanto educacional quanto clínico) a esses indivíduos passam a ser realizados em ambientes específicos (escolas especiais, clínicas de reabilitação, centros de atendimento) (Dechichi, 2001). A prática da segregação social perdurou até início do século XX e, a partir da segunda metade do século, ela vai gradativamente dando lugar a ideais e práticas de integração social ${ }^{14}$. No final do século XX, são particularmente valorizadas as avaliações de inteligência e os métodos quantitativos de categorização do nível da limitação do sujeito no diagnóstico clínico da deficiência ${ }^{15}$ (neste caso, a intelectual), chegando a quase se tornar a única referência para identificação dessa população (AAIDD, 2010).

A partir do ano 2000, com as neurociências, o déficit intelectual passou a representar um foco de interesse de muitas pesquisas no âmbito da Psicologia do Desenvolvimento. Entretanto, ainda hoje predominam estudos relacionados à etiologia, a processo diagnóstico com validação de instrumentos, processosłcorrelações variadas entre déficit cognitivo e campos de conhecimento específico do funcionamento psíquico (Mello, Argollo, Shayer, Abreu, Godinho, Duran, Vargem, Muszkat, Miranda, \& Bueno, 2011; Elians, Goyos, Saunders \& Saunders, 2008; Rossit \& Goyos, 2009) e

\footnotetext{
${ }^{14}$ Movimento social que pressupõe a inserção das pessoas com deficiência em ambientes escolares e contextos sociais de pessoas sem deficiência. Há o oferecimento de todo um atendimento para que as limitações provocadas por cada deficiência possam ser superadas e o convívio garantido. Dentro dessa perspectiva as mudanças necessárias para garantir essa inserção devem ocorrer naquele/com o sujeito com deficiência. É ele que deve se adequar a realidade do mundo construído para o sujeito sem déficit.

${ }^{15}$ A partir dos trabalhos de Jean Itard (1774-1838), Pestalozzi (1746-1827), Montessori (1870-1925) e Froebel (1782-1852) desenvolveram seus estudos dirigidos a educação das pessoas com deficiência mental (Pletsch, 2010)
} 
aqueles voltados à mensuração de aspectos cognitivos (Cecato, Fiorese, Bartholomeu, Bastos, Grogolato \& Martineli, 2012). As interações e o processo de desenvolvimento da criança com déficit intelectual continuam como assuntos pouco explorados e, quando o são, partem de estudos que não consideram o processo em si do fenômeno em estudo (Freitas \& Del Pretti, 2013; Batista \& Emuno, 2004) ou são estudos que consideram a centralidade das relações da criança com deficiência com o adulto (Freitas, 2006).

Outro importante elemento pertencente à trama da constituição do déficit intelectual na atualidade diz respeito às políticas públicas, a última versão da Política de Educação Especial dentro da Perspectiva da Educação Inclusiva (Brasil, 2014). Além de esclarecer esse o percurso histórico, demarca as políticas públicas na perspectiva de garantir a inserção, participação efetiva e o atendimento especializado nos contextos escolares. A inclusão escolar prevista neste documento é calcada na transformação das estruturas sociais e, acima de tudo, na mudança cultural em torno da deficiência (identificada no documento como barreira atitudinal) com um investimento específico nos processos de formação de professores. Assim, ao considerar que o desenvolvimento humano se dá por meio da relação com o outro e que, no caso da pessoa com deficiência, essa relação é marcada pelos processos acima descritos (exclusão, segregação, integração), as transformações sociais que desembocam na recente inclusão da pessoa com deficiência no contexto social caracterizam-se por um fenômeno social inédito. As pesquisas, entretanto, ainda estão bastante concentradas nas investigações de ordem orgânica e pouco se sabe sobre os processos de desenvolvimento desse indivíduo, especialmente da criança pequena com déficit intelectual.

Ainda, considerando que um dos grandes entraves apontados pelas políticas públicas é justamente a barreira atitudinal que depende de uma mudança cultural, identifica-se uma lacuna no que tange a produção de conhecimento na área. Entender como os processos interacionais ocorrem, quais são e como se dão as construções de significados para, posteriormente, buscar-se analisar a produção de cultura tendo como sujeito social a pessoa com déficit intelectual nesse processo, mostrase como condição sine qua non para que as transformações sociais esperadas ocorram.

\subsubsection{A caracterização do déficit intelectual e a noção de desenvolvimento a partir das contribuições de Vygotsky}

Atualmente, como já referido, o déficit intelectual é caracterizado pela American Association on Intellectual and Development Disabilities (AAIDD) como: "significante limitação ambos no funcionamento intelectual e no comportamento adaptativo expresso em habilidades conceituais e práticas. Esse déficit se inicia antes dos 18 anos de idade” (AAIDD, 2010. p. 1). Para além do já 
referido nas edições anteriores da conceituação feita por essa Associação, a versão de $2010^{16}$ traz alguns elementos complementares para que o diagnóstico seja feito. Esses elementos são:

- As limitações na funcionalidade devem ser consideradas dentro do contexto do ambiente social tipicamente da idade do indivíduo, seus pares e cultura;

- A avaliação válida considera diversidade cultural e linguística, assim como as diferenças na comunicação, fatores sensoriais, motores e comportamentais;

- Considerando o indivíduo, as limitações normalmente coexistem com potencialidades;

- Um importante propósito da descrição de limitações é a construção de um plano de suporte;

- Com suporte personalizado apropriado, sustentado por um período de tempo, a vida funcional do indivíduo com deficiência intelectual geralmente melhora.

A atual abordagem ao fenômeno da deficiência é, portanto, entendida por Plestch (2010), além de Ferreira, Vectore e Dechichi (2013), como um avanço para a compreensão da deficiência enquanto uma possibilidade na condição humana e um fenômeno que necessita ser melhor entendido na sua existência e relação com os contextos sociais. A definição apresentada pela AAIDD (2010) tem, dessa forma, como objetivo, trazer a possibilidade de uma discussão que considera múltiplos os caminhos para o desenvolvimento humano.

Apesar das significativas conquistas para o atendimento educacional das pessoas com déficit intelectual e, consequentemente, a melhoria na inserção social, o manual da AAIDD também reforça a necessidade permanente de recursos de suporte como elementos que visam garantir $o$ desenvolvimento desse indivíduo, atribuindo a esses suportes um papel central no processo de compreensão do fenômeno da deficiência.

Entretanto, mesmo em se tratando de avanços significativos na compreensão da relação biopsico-social na deficiência intelectual, quando se analisa, à luz das contribuições de Vygotsky, a caracterização feita pelo AAIDD e o texto teórico que compõe o manual de diagnóstico, entende-se que alguns elementos ainda não são discutidos sobre o fenômeno do desenvolvimento humano do indivíduo com déficit intelectual. Dentre eles, pode-se citar: (1) a necessidade de se considerar as inúmeras possibilidades interacionais que constituem o social para essa criança e; (2) a dialética presente na constituição humana e com ela o papel ativo do indivíduo com deficiência ao longo do processo de construção do fenômeno.

A importância do trabalho de Vygotsky para a compreensão do desenvolvimento do indivíduo com deficiência é que esse autor "rompe com a naturalização da deficiência como enfermidade e, embora não tenha desenvolvido a categoria como sentido, já se observa em sua produção teórica uma

\footnotetext{
16 Para a apresentação do conceito a versão de 2006 também apresenta o mesmo texto. (AAMR, 2006. p.viiiix)
} 
ênfase nas várias consequências de uma experiência segundo a maneira como ela é vivida" GonzalezRey (2012. p.35). Essa leitura sobre a deficiência sustenta uma nova forma de compreender o déficit como uma produção cultural, relacionando-o aos processos de vida social e da psique humana.

Tal ruptura, entretanto, não garantiu uma compreensão ampliada da ação do outro na constituição do sujeito quando esse tem uma deficiência. A deficiência dentro dessa perspectiva não imputa ao sujeito outro tipo de desenvolvimento, "todas as funções superiores formam-se não na biologia nem na história da filogênese pura - esse mecanismo, que se encontra na base das funções psíquicas superiores, tem sua matriz no social" (Vygotsky, 2011.p. 864). Ou seja, o desenvolvimento continua sendo histórico e cultural. Entretanto, esse desenvolvimento se dará por caminhos alternativos, caminhos estes que garantirão o acesso aos signos produzidos pela cultura, majoritariamente composta de pessoas sem deficiência (Vygotsky, 2011).

Como ele afirma,

"Por um lado, ele (defeito) é uma deficiência e atua diretamente como tal, produzindo falhas, obstáculos, dificuldades na adaptação da criança. Por outro lado, exatamente porque o defeito produz obstáculos e dificuldades no desenvolvimento e rompe o equilíbrio normal, ele serve de estímulo ao desenvolvimento de caminhos alternativos de adaptação, indiretos, os quais substituem ou superpõem funções que buscam compensar a deficiência e conduzir todo o sistema de equilíbrio rompido a uma nova ordem" (Vygotsky, 2011.p.)

Assim, a ação do outro fica relacionada à possibilidade de implementação desses caminhos alternativos

“(...) as formas culturais de comportamento são o único caminho para a educação da criança anormal. Elas consistem na criação de caminhos indiretos de desenvolvimento onde este resulta impossível por caminhos diretos. A língua escrita para os cegos e a escrita no ar para os surdos-mudos são tais caminhos psicofisiológicos alternativos de desenvolvimento cultural” (Vygotsky, 2011. p.868).

Aqui cabe a consideração de um importante conceito da obra de Vygotsky, a compensação. Trata-se do processo pelo qual o indivíduo com déficit desenvolve ferramentas para se apropriar dos instrumentos e signos constituintes na cultura, uma reorganização psicológica. De acordo com Van 
Der Veer e Valsiner (2014), o estímulo central que permite ao sujeito o desenvolvimento de funções compensatórias está na interação social; é no material produzido nosldos seus comportamentos sociais que esse indivíduo encontrará o que precisa para prosseguir com a formação das funções mentais superiores.

Para Dainêz (2009; 2014), apesar de o termo não ser o mais adequado para expressar a relevância conceitual, a compensação social (muito mais significativa do que a orgânica) foi o ponto central da teoria de Vygotsky para explicar como o indivíduo com diferente aparato físico pode e deve percorrer os mesmos objetivos de aprendizagem dentro do contexto escolar. Apesar de que, em seus estudos, a autora centra-se no papel do professor para a promoção das funções compensatórias em crianças com déficit intelectual, ela constata importantes momentos de interação entre pares como sendo situações em que a compensação é colocada em prática.

Uma reflexão cabível sobre esse pensamento dentro da esfera da escola regular atual, mais precisamente sobre a estruturação da prática pedagógica frente aos alunos com déficit intelectual, refere-se à valorização da atuação exclusiva do professor no suporte pedagógico para a criança com déficit intelectual. As inúmeras outras possibilidades interacionais presentes no contexto escolar são colocadas como elementos secundários (quando não, ignorados), entendidas como situações que podem vir a favorecer, mas que não determinam o processo. Perdem-se possibilidades de interlocução com importantes atores no contexto social, particularmente os pares.

Outro ponto de destaque é que, ao mesmo tempo em que a criança com déficit intelectual está sendo constituída por meio do social, esse também é constituído por ela. No entanto, usualmente, não se considera a ação que a criança com déficit terá no meio em que está imersa e logo se desconsidera a atividade dessa criança no processo interativo, perdendo-se o dialogismo presente no processo de constituição humana. Contudo, o déficit não imputa passividade ou unilateralidade ao processo de desenvolvimento, o que permite o questionamento de quais seriam as implicações para o outro na interação com a criança com déficit intelectual.

Esse dialogismo pode ainda ser discutido sob um prisma mais ampliado no contexto escolar. Ao se considerar que os caminhos alternativos servem para oportunizar aos sujeitos com deficiência novos acessos aos signos, caberia, então, à educação, garantir que caminhos alternativos fossem oportunizados a fim de que esse desenvolvimento pudesse vir a ser favorecido. Cabe ainda lembrar que a escola à qual Vygotsky se refere em seu texto sobre defectologia não é a escola regular que atende a todas as crianças - a escola na perspectiva da inclusão escolar. Pelo contrário, trata-se de uma escola especial, estruturada com o objetivo de adaptar (readaptar) o aluno com deficiência para 
uma vida social em um mundo organizado por indivíduos sem deficiência ${ }^{17}$, em um processo educacional integracionista, contexto pertinente ao momento histórico e social de vida do autor.

Mas, ao se considerar essa mudança no paradigma escolar contemporâneo entende-se que os caminhos alternativos que outrora garantiam o desenvolvimento, hoje têm outro formato. A criança com deficiência tem sido cada vez mais vista como participando do processo de construção desses elementos culturais, o seu desenvolvimento podendo vir a acontecer através da aquisição desses signos e o processo de significação agora podendo ser compartilhado com as crianças que não têm deficiência. O elemento definidor desse processo torna-se então a vivência desses sujeitos nos contextos sociais onde se compartilham e (re)constroem significados. Adotar esses questionamentos como orientadores para a análise das interações entre pares na pré-escola, dentro da perspectiva da teoria histórico-cultural, demanda retomar as discussões sobre Zona de Desenvolvimento Proximal e, ainda, sobre como ocorre a interlocução entre desenvolvimento e aprendizagem no trabalho com a criança com déficit intelectual.

\subsubsection{Discutindo o conceito de ZPD dentro da perspectiva do trabalho com crianças com déficit intelectual na atualidade}

No exercício de trazer o conceito da Zona de Desenvolvimento Proximal para o estudo em torno do desenvolvimento de crianças com déficit intelectual, aponta-se dois elementos para reflexão: (1) o que se pode considerar como indícios de desenvolvimento quando se olha para as relações entre pares?; e, (2) quem é esse outro e de que forma ele perpassa o desenvolvimento da criança com déficit intelectual?

Ao descrever o conceito de ZDP, fica evidente a relação que Vygotsky aponta entre esse conceito e a discussão das possíveis associações entre desenvolvimento e aprendizagem. Em " $O$ problema do ensino e do desenvolvimento mental na idade escolar", Vygotsky (2010) não explicita quais seriam os elementos que serviriam de indícios para se analisar a ZDP; nem poderia, haja visto sua característica puramente teórica e abstrata. Genericamente, entende-se que atividades que a criança consegue realizar autonomamente acessam os limites consolidados das suas funções mentais e que as atividades que a criança realiza com a participação de um mediador sinalizam suas potencialidades, logo, os caminhos do seu desenvolvimento. Mas, que atividades seriam essas?

Ao trazer o exemplo das duas crianças de sete anos que apresentam resultados diferentes para o processo de testagem, Vygotsky, (2010, p. 479) se refere a atividades provenientes de testes de

\footnotetext{
${ }^{17}$ Documentário feito pela BBC em 1992, intitulado por Borboletas de Zagorsk, mostra uma instituição escolar russa estruturada a partir dos pressupostos de Vygotsky para uma educação de pessoas com déficits sensoriais e intelectuais.

Disponível em https://www.youtube.com/watch?v=bA GMtqUGeQ\&list=PL858E4B95400A472C acessado em: 30 de agosto de 2014
} 
inteligência ou de contexto escolar. Porém, quando menciona, no parágrafo seguinte, o "problema da imitação", mesmo desconsiderando o teor do processo imitativo como indício de desenvolvimento, o autor abre espaço para se pensar em outros tipos de atividades que não as estritamente acadêmicas para revelar tal processo de desenvolvimento. Ao considerar que tais atividades se restringem àquelas voltadas à mensuração de funções mentais específicas, está-se considerando desenvolvimento como o equivalente de cognição, ou que a cognição só perpassa esses tipos de atividades escolares?

Os textos, como já mencionado, são voltados para a finalidade de se pensar em contextos educacionais e, portanto, atingem pertinentemente a esse propósito. Entretanto, o objetivo do autor não foi somente a contribuição no âmbito escolar e suas propostas teóricas apresentaram outros temas mais amplos ao longo de sua curta vida. A partir de outros textos do autor (Vygotsky, 2008; 1999; 2014), encontram-se indícios de que o desenvolvimento seja considerado como algo que vai além da esfera cognitiva. Como ele afirma,

"Frequentemente, explicamos o desenvolvimento da criança pelo prisma de suas funções intelectuais, ou seja, diante de nós, qualquer criança apresenta-se como um ser teórico que, dependendo do maior ou menor nível de desenvolvimento intelectual, passa de um degrau etário para outro. Não são consideradas as necessidades e as inclinações da criança, seus impulsos, os motivos de sua atividade, sem o que, como demonstra o estudo, nunca ocorre a passagem da criança de um estágio para o outro" (Vygotsky, 2008. p. 24).

Segundo Prestes (2012), Vygotsky defende assim a indissociabilidade entre afeto e intelecto, indicando que ambos se caracterizam por uma unidade. Não existem, nesta perspectiva, dois tipos de dinâmica ou dois tipos de atividade (uma intelectual e outra emocional). Essa ideia é confirmada ao longo da leitura do texto defectologia, quando Vygotsky esclarece a importância da atividade para sua teoria e a compreensão do déficit, mas também vai pontuar como a unidade cognição (intelecto) e afeto fazem parte da consciência humana ou da personalidade, como discute Gonzalez-Rey (2012).

Dessa forma, quando o conceito de Zona de Desenvolvimento Proximal é analisado, compreende-se que a atribuição de condição sine qua non, atribuída à atividade intelectual, pode não contemplar, na totalidade, o que Vygotsky entendia como desenvolvimento. A hipótese é que, ao se considerar o desenvolvimento humano proveniente de uma unidade intelecto/afeto, não necessariamente a Zona de Desenvolvimento Proximal vincular-se-á exclusivamente à atividade 
acadêmica ou a uma atividade de testagem específica. A unidade respeitada enquanto indissociável prevê outros elementos desse processo de desenvolvimento.

Goés e Smolka (1997), ao discutirem sobre a Zona de Desenvolvimento Proximal, consideramna como um espaço simbólico de construção que, a partir de uma relação dialógica, permite aprendizagens diversas (aprendizagens estas que, dentro da perspectiva de Vygotsky, podem promover o desenvolvimento). Esse olhar amplia as possibilidades de análise desse processo e reforça a ideia de que as interações e o papel destas é imprescindível para a transformação daquilo que pode vir a ser realidade.

Segundo Smolka (2004), ao tematizar sobre o desenvolvimento humano, Vygotsky “propunha a análise da cultura e da história como integrantes do processo" (pp. 40) e trazia para discussão a cognição, o conhecimento, a emoção e a imaginação como elementos centrais, discutidos a partir da ideia de que é a significação (criação e o uso de signos) o percurso para a constituição do ser humano. A partir dessas referências, os processos interacionais configuram-se, então, como o elemento central para a discussão sobre o desenvolvimento, esse que é único e multideterminado.

Sobre a interação como unidade de análise daquilo que promove o desenvolvimento, segundo ponto de reflexão elencado nos textos "A análise pedológica sobre o processo pedagógico" (Vygotsky, 2010) e “Aprendizagem e desenvolvimento na idade escolar" (Vygotsky, 2005) a relação entre o conceito de Zona de Desenvolvimento Proximal e o desenvolvimento mental, ou ainda, a ZDP e a ação do mediador adulto ficam bastante evidenciadas. Embora não esteja explicitado por Vygotsky, tal relação é vista como contribuindo para a sedimentação da ideia de que a consciência no processo de mediação da aprendizagem do outro seja um elemento imprescindível para a promoção do desenvolvimento desse sujeito.

Entende-se que essa ideia vai fortalecer o pressuposto de que seja o adulto o responsável a viabilizar a transformação daquilo que é potencial em real na criança, especialmente naquela acometida por um déficit intelectual. Pode-se fazer essa relação quando se analisa conjuntamente as políticas de formação de professores para a atuação junto aos alunos com déficit intelectual e percebese o direcionamento completo ao professor como o responsável não só pelo desenvolvimento de práticas pedagógicas com vistas ao desenvolvimento, mas da garantia da efetivação do processo de inclusão ${ }^{18}$.

Ou ainda, quando outros estudiosos (Forman \& Mcphail, 1993; Forman \& Cazden, 1985; Gartner \& Riessman, 1993; Saxe, Gearhart, Note \& Paduano, 1993; Tudge, 1990), mesmo abordando - desde a década de 1990 - que o papel mediacional não seja só do adulto, mas de crianças na

\footnotetext{
${ }^{18}$ Este assunto será abordado com maior detalhamento quando da menção do desenvolvimento de crianças com déficit intelectual, no próximo subcapítulo.
} 
construção/atuação nessa janela de desenvolvimento, assim o fazem condicionando a características específicas da atuação das mesmas: (1) São crianças mais velhas ou mais aptas (naquela atividade específica) que a outra no processo de interação; e, (2) Participam conscientemente do processo de construção do conhecimento ou desenvolvimento da outra criança menos apta (Gartner \& Riessman, 1993).

Mas, seriam somente as intervenções conscientes que provocariam o processo de aprendizagem e desenvolvimento)? E quando ocorrem regulações ${ }^{19}$ de comportamento que não têm em sua essência esse objetivo? Ou ainda e quando situações onde não há atividade conjunta resultam em regulações de comportamentos? Tais questionamentos levam à reflexão sobre outros elementos presentes nessa interação e que são também caros a Vygotsky: especificamente, os elementos afetivos e a vivência de cada criança.

Em se considerando a relevância do social no referencial teórico de Vygotsky (Pino, 2000), pode-se indagar ainda sobre quem são os outros possíveis nessa relação de desenvolvimento da criança? Como eles se tornam relevantes para esse sujeito? Para além disso, visto que a interação de indivíduos, do indivíduo com o meio e nele o que histórica e socialmente foi construído é a chave para se entender a constituição da personalidade (conceito que Vygotsky vai entender por resultado da unidade cognição e afeto), há de se considerar que as experiências vividas nessas interações embora compartilhadas - são vivenciadas de forma individual (González-Rey, 2011).

Neste sentido, quando o próprio Vygotsky, ao discorrer que o ensino para crianças mentalmente retardadas ${ }^{20}$ não deve partir daquilo que já é de seu domínio, exemplificando que o "sistema de ensino que se baseia apenas no método direto e exclui tudo aquilo que está ligado ao pensamento abstrato, não só não ajuda a criança a superar a sua deficiência natural como a afunda" (Vygotsky, 2010. p.481), entende-se que se abre espaço para a reflexão de que todos processos interacionais que demandam recursos ainda não desenvolvidos nessa criança a colocam em situação de desenvolvimento. Mas não é qualquer interação que provocará o engajamento necessário para a promoção do desenvolvimento; é sim uma interação que suscita na criança algo que seja possível de ser compartilhado. Buscar compreender como esses processos acontecem pode trazer significativas contribuições para a discussão do desenvolvimento humano, especialmente no que tange ao déficit intelectual. Para discorrer mais sobre isso, importa tratar desse tema em específico.

No presente estudo, o foco é justamente o processo de desenvolvimento contido nas interações de pares na educação infantil, com especial olhar sobre a criança com déficit intelectual neste

\footnotetext{
${ }^{19}$ Conceito trabalho por Carvalho; Branco, Pedrosa, \& Gil (2002) e que será discutido de forma mais aprofundada no capítulo sobre Processos interacionais e construção de cultura na infância.

${ }^{20}$ Termo trazido pelo autor.
} 
contexto. Diante disso, inúmeros são os questionamentos que podem ser levantados: Como acontece essa interação? Que elementos da corporeidade participam da construção nessa interação de crianças com e sem déficit? Seria o par de idade um propiciador desse desenvolvimento, considerado como mediador da construção de uma ZDP? A compreensão sobre como ocorrem essas interações pode auxiliar na discussão da inclusão escolar? 


\section{Hipóteses e Objetivos}

\section{Hipóteses}

Diante das observações teóricas expostas sobre a gênese social do desenvolvimento humano e da visão sociológica da participação ativa da criança na construção da cultura, acredita-se que os processos interacionais, manifestados pelas regulações e corregulações de comportamento da criança com déficit intelectual e seus pares de idade, proporcionados no contexto regular de educação infantil, seja um elemento promotor do desenvolvimento humano para esses sujeitos. Mais especificamente, acredita-se que as regulações e corregulações de comportamento de pares delineiam o percurso vivencial do sujeito com déficit intelectual neste contexto social e, por esse percurso, também haja a possibilidade de construção de habilidades potenciais em reais. Essa relação entre pares, contínua e possivelmente não intencional, definiria então Zonas de Desenvolvimento Proximal, mostrando-se ser um elemento essencial no processo de desenvolvimento da criança com déficit intelectual no contexto regular de educação, levando ao objetivo desse estudo.

\section{Objetivos}

Com este estudo buscou-se apreender os processos interativos de crianças com e sem déficit intelectual no contexto da educação infantil, tendo como meta a identificação de comportamentos regulados e corregulações entre os pares. Uma vez identificados os processos de regulação, buscouse analisar como as relações estabelecidas entre pares são construídas e, nessa construção, como possibilitam a transformação das habilidades potenciais em reais, em diferentes atividades. A meta foi identificar se existem indícios empíricos que sustentariam a discussão conceitual de que o impacto das regulações de comportamento por pares de idade também poderia ser considerado elemento que cria Zonas de Desenvolvimento Proximal às crianças com déficit intelectual. 


\section{Metodologia}

Na estruturação do delineamento metodológico de uma pesquisa, o foco sobre o fenômeno em estudo e os objetivos do processo investigativo constituem-se como elementos essenciais para a definição operacional da mesma. É por meio desses que as escolhas teórico-metodológicas se justificam e por onde perpassam a eleição dos recursos de coleta e os métodos de análise dos dados. Tendo em vista essa compreensão, nas linhas que seguem, apresenta-se o percurso pelo qual essa pesquisa foi pensada e conduzida.

Inicialmente, trata-se sobre quais perspectivas teórico-metodológicas se embasa o presente trabalho e, posteriormente, detalhar-se-á sobre os estudos de caso construídos, as escolhas dos recursos de coleta de dados e os procedimentos para as análises. Ressalta-se, ainda, que a metodologia aqui apresentada considera as especificidades do contexto pré-escolar, a multiplicidade fatorial que constitui o processo de desenvolvimento humano e a singularidade do olhar metodológico necessário para a viabilização de uma pesquisa com crianças.

Como referencial metodológico, determinou-se abordar o fenômeno em questão por meio de uma perspectiva qualitativa de investigação, o que segundo González-Rey (2002) significa, entre outras coisas, "assumir a subjetividade no processo de construção de conhecimento, rompendo com paradigmas de neutralidade que impossibilitam dissociar o vínculo isomorfo e linear da pesquisa com o momento empírico e ter os processos, os sentidos e as construções sociais como objetos de estudo" (p.14).

Sobre a subjetividade preconizada na pesquisa qualitativa, González-Rey (2002) afirma que ela "é determinada socialmente, mas não por um determinismo linear externo do social ao subjetivo, e sim em um processo de constituição que integra de forma simultânea as subjetividades social e individual" (p.37). O processo investigativo delineado sob a perspectiva qualitativa objetiva conhecer um dado fenômeno, os seus sentidos, os seus percursos constitutivos, as relações complexas e multideterminantes que o circunscrevem e é entendida como um caminho para entrar em "zonas de sentido ocultas pela aparência" (González-Rey, 2002, p.33), uma forma de analisar um fenômeno pela subjetividade expressa por aqueles que fazem parte dele.

A escolha pela metodologia qualitativa justifica-se, preponderantemente, pelo fato de que nenhuma proposta quantitativa acolheria a complexidade relacional que compõe o presente objeto de estudo. Ainda, é preciso enfatizar que, na análise das subjetividades individuais, tem-se a possibilidade de apreender aspectos do fenômeno social, uma vez que a subjetividade é determinada socialmente e reflete em si parte do fenômeno (Minayo, 2006). Através da metodologia qualitativa, acredita-se ser possível a construção de conhecimentos acerca dos processos de desenvolvimento, 
enxergando-o a partir de diversos elementos inseridos em seus diferentes contextos de interação social.

Dentro da perspectiva da pesquisa qualitativa recorre-se, para pensar sobre o método aqui proposto, às contribuições do referencial da Rede de Significações (RedSig) que se caracteriza como um olhar, uma forma de enxergar o processo investigativo frente ao fenômeno do desenvolvimento humano. Ou, como as próprias autoras afirmam, "uma ferramenta capaz de auxiliar tanto nos procedimentos de investigação como na compreensão do processo de desenvolvimento humano" (Rossetti-Ferreira, Amorim e Silva, 2004, p.23).

Por essa perspectiva teórica, o desenvolvimento humano é entendido como se dando dentro de processos (inter)relacionais complexos, imersos em diferentes contextos sociais e esferas temporais que, por sua vez, relacionam-se entre si em diversas instâncias, formando uma densa malha de elementos de natureza semiótica (Rossetti-Ferreira, Amorim \& Silva, 2000). A contradição e complementaridade presentes na natureza humana tem igual lugar na composição do processo de desenvolvimento e assim são considerados ao longo de todo o processo investigativo.

Há ainda, na proposta, uma compreensão de que, no percurso de se investigar um fenômeno que se configura em um cenário de complexidade, o pesquisador é ferramenteiro e necessita criar estratégias para acessar essa complexidade.

No que tange às contribuições da RedSig para os aspectos metodológicos deste estudo, julga-se pertinente e imprescindível destacar três pontos que evidenciam por qual prisma teórico a observação do fenômeno estudado está sendo construída e, assim, quais são características metodológicas da presente pesquisa. Esses pontos são: (1) o delineamento que permita a compreensão sobre o desenvolvimento como resultado de múltiplos e entrelaçados fatores; (2) a postura de pesquisador ferramenteiro, e; (3) o processo de análise de dados feito de forma relacional e contextual.

Rossetti-Ferreira [et al] (2008) apontam como um dos desafios metodológicos na pesquisa com base na perspectiva da RedSig a própria compreensão de como a complexidade pela qual o desenvolvimento humano é constituído; ainda, de como os diferentes sistemas confluem e se fazem presentes em /parte do sujeito no momento e contexto da investigação. Assim, na busca por tentar respeitar essa forma de enxergar o desenvolvimento humano, a investigação feita deve levar em consideração essa complexidade, mesmo que dentro de um recorte espaço/temporal específico.

A escolha pelo estudo de caso é vista como uma possibilidade de se trabalhar com essa complexidade. O delineamento está desenhado a partir de estudos de caso múltiplos, o que, segundo Yin (2010), configura-se como um dos métodos científicos que "permite ao pesquisador reter as características holísticas e significativas dos eventos da vida real” (p. 24) (...) “especialmente quando os limites entre o fenômeno e o contexto não são claramente evidentes” (Yin, 2010. p. 39). Ou seja, 
quando o contexto em que o fenômeno se dá está tão diretamente imbricado na sua constituição, que a separação entre eles ou a tentativa de sua anulação acarretaria a própria dissociação do fenômeno. A característica fundamental do estudo de caso reside na concentração do processo de coleta de dados em um único ou em alguns percursos de vida (ou situações específicas), o que demanda um trabalho com um número elevado de elementos sem a dissociação entre eles e o contexto, fazendo com que o estudo seja conduzido de forma a abarcar aspectos de modo ampliado.

Com o estudo de caso é possível observar os vários sistemas envolvidos no processo de constituição do sujeito, analisar as relações estabelecidas entre eles e acompanhar processos ao longo do tempo. Esses elementos são apontados como importantes para a análise do desenvolvimento dentro da perspectiva da RedSig (Rossetti-Ferreira, Amorim, Soares-Silva \& Oliveira, 2008).

Estudos de caso possibilitam uma aproximação a determinados fenômenos (sociais ou humanos) de modo a que se consiga apreender indícios e evidências de "como" e "por quê" algo acontece em determinada situação ou contexto. Segundo Yin (2010), estudos de caso podem responder a pesquisas exploratórias, descritivas ou explanatórias, dependendo do objetivo e dos procedimentos que serão dispendidos no processo de coleta e análise dos dados; possibilita, portanto, que diferentes recursos de coleta de dados sejam empregados.

Para este tipo de estudo, portanto, o pesquisador necessita adotar uma postura de ferramenteiro buscando alternativas e diferentes formas de entrar em contato com o objeto de estudo. Trata-se de uma postura ativa, reflexiva e crítica sobre o processo de investigação podendo, a depender dos desafios na própria pesquisa, criar novas formas de olhar para o fenômeno e estudá-lo. Essa postura só é possível a partir de imersões no campo, de forma que possibilite compreender o espaço, tempo e as relações que circunscrevem o cenário. Posteriormente, tendo em mãos materiais provenientes de uma coleta ampla, suas análises vão se dar considerando o movimento, os processos, as (re)construções ocorridas de forma processual e contextual, significando que os dados são discutidos mantendo os entrelaces teóricos realizados e as diferentes fontes de informação utilizadas nas etapas anteriores (Rossetti-Ferreira, Amorim, Soares-Silva \& Oliveira, 2008; Carvalho, Pedrosa \& Amorim, 2006).

\subsection{Cuidados éticos}

É importante destacar que, antes de iniciar a condução dos estudos, o projeto foi submetido e aprovado pelo Comitê de Ética em Pesquisa com Seres Humanos da FFCLRP, da Universidade de São Paulo. O compromisso com o respeito às normas éticas de pesquisa com seres humanos, de sigilo, de respeito aos sujeitos e contextos investigados foram firmados e assim respeitados ao longo de todo processo. 
Para a garantia de que todos os participantes envolvidos, direta ou indiretamente, estivessem de acordo com os procedimentos metodológicos da pesquisa, Termos de Consentimento Livre e Esclarecido foram utilizados. Todos os participantes foram voluntários e a pesquisa ocorreu de forma a não implicar em nenhum tipo de custo para os mesmos.

As entrevistas e demais procedimentos de registro foram realizadas em local e horário indicados pelos participantes. Os áudio-registros foram feitos mediante a autorização dos mesmos. Os vídeoregistros dos processos interacionais foram realizados nas escolas com a devida autorização de todos os envolvidos. Todo material gravado foi disponibilizado para os participantes da pesquisa.

Sobre possíveis benefícios, os participantes foram informados de que, ao final do processo investigativo, a pesquisadora se comprometia a fazer uma devolutiva sobre os principais aspectos encontrados ao longo da pesquisa, entregando uma cópia digital do material produzido derivado do estudo; e ainda de que estaria à disposição para eventuais dúvidas. No que tange às famílias participantes, entende-se que essa contrapartida ofereça a oportunidade para se conhecer melhor sobre o desenvolvimento das crianças envolvidas. Para os profissionais participantes, entende-se que esse material possa oportunizar momentos de reflexão sobre o próprio contexto escolar e os processos interativos na sala de aula. Espera-se que o material produzido possa trazer para as instituições elementos reflexivos que subsidiem a elaboração de programas de capacitação e formação de profissionais da área, a fim de promover práticas que considerem o desenvolvimento humano no processo de escolarização, ao envolver crianças com necessidades especiais.

Todos os dados de identificação nominal dos participantes foram tornados anônimos. Os extratos dos vídeos, utilizados para ilustrar e explicitar as análises realizadas, sofreram uma alteração com filtro de imagem a fim de que as características físicas dos participantes não fossem reveladas. O banco de dados dos vídeo-registros ${ }^{21}$, bem como as transcrições das entrevistas com os familiares e professores foram utilizados estritamente para fins de pesquisa, devendo ser destruídos após a conclusão e publicação dos resultados desse estudo.

\subsection{Critérios de inclusão e exclusão}

A partir do contato com diversas Instituições de Educação Infantil de uma cidade do interior de Minas gerais, a escolha dos participantes foi realizada a partir da inclusão/exclusão da criança pivô. A escolha desta respeitou os seguintes critérios de inclusão e exclusão: (a) diagnóstico de déficit intelectual; (b) acompanhamento da criança com déficit intelectual pelo Atendimento Educacional

\footnotetext{
${ }^{21}$ Foi concedida a pesquisa que extratos de vídeo-registros podem ser utilizados apenas em fóruns científicos com vistas a divulgação dos resultados deste trabalho. Publicações devem priorizar o sigilo e a impossibilidade de identificação dos participantes.
} 
Especializado - $\mathrm{AEE}^{22}$, fosse ele realizado na própria escola ou em outra instituição. Esse tipo de atendimento denota que a criança em questão é enxergada e atendida pela escola como uma criança com déficit intelectual; (c) diagnóstico de déficit intelectual sem co-morbidades físicas que impeçam o deslocamento livre da criança pelo ambiente escolar. Ressalta-se que esse diagnóstico é emitido por equipe multidisciplinar encarregada pelo acompanhamento da criança em outros atendimentos fora da escola. Esse diagnóstico é exigido pelo AEE e fica em arquivo na escola ao longo de todo processo de escolarização da criança; e, (d) aquiescência da família para o processo de coleta de dados.

Destaca-se ainda que não foi realizado nenhum tipo de avaliação cognitiva padronizada dessas crianças pela pesquisadora. A identificação e seleção das crianças utilizou-se somente das avaliações e diagnósticos apresentados pelo Atendimento Educacional Especializado como material de comprovação do déficit intelectual. Os laudos comprobatórios fazem parte de uma solicitação legal para a inclusão da criança no censo escolar. Tal laudo é normalmente realizado por uma equipe multidisciplinar pertencente à instituição e/ou por psicólogos ou médicos da rede de saúde fora da escola que se responsabilizam por tais avaliações. Dessa forma, entende-se que, com o critério de inclusão dos participantes supracitado, fica assegurada a condição de déficit, mesmo que a pesquisadora em si não aplique nenhum tipo de avaliação padronizada.

Para a definição da participação dos pares, os colegas de sala das crianças com déficit intelectual foram considerados participantes, particularmente aquelas crianças que compartilharam com a criança pivô das vivências e relações na mesma classe escolar. O objetivo era privilegiar o foco de análise sobre aqueles pares cuja incidência de situações de interação foi maior ao longo do período de tempo observado no ano letivo ou que tenham participado em um momento considerado de maior relevância para o presente estudo. O processo de identificação dos pares participantes aconteceu no momento de análise dos registros de interação que, ao considerar os recortes interativos mais significativos, acabou também por selecionar os parceiros envolvidos no processo. Essa identificação dos pares foi inspirada em procedimento adotado em pesquisas observacionais semelhantes, realizadas também com crianças pequenas (Moura, 2012; Del'Solle, 2013; Bieler \& Moura, 2000).

Embora o foco da pesquisa seja o processo interacional entre as crianças, estas estão inseridas em um contexto social estruturado por adultos, culturalmente vistos como principais mediadores dos processos de desenvolvimento. Sendo assim, a partir do referencial teórico-metodológico que embasa esse estudo, torna-se imprescindível considerar esses adultos como participantes da pesquisa. Segundo diversos autores (Rossetti-Ferreira, Amorim \& Silva, 2000; Rutanen, 2012; Rutanen,

\footnotetext{
$22 \mathrm{O}$ Atendimento Educacional Especializado caracteriza-se por um serviço escolar que visa o desenvolvimento de recursos, habilidades ou conhecimentos específicos que auxiliem alunos com deficiências física, sensoriais, intelectuais, transtornos do desenvolvimento e ou altas habilidades/superdotação no seu processo de escolarização.
} 
Amorim, Colus \& Piattoeva, 2014; Raittila, 2012; Tudge, 2008), a organização do espaço realizada pelo adulto interfere, promove, inibe ou modifica as ações e, consequentemente, contribui para circunscrever o desenvolvimento das próprias interações ali sendo construídas. As referências de mundo desse professor, suas ideias e concepções sobre seu trabalho, e mesmo sobre o próprio déficit, são elementos que contribuem para compor o contexto escolar, nas rotinas diárias, na elaboração das atividades e nas ações com as crianças.

Os familiares (pai, mãe ou outro responsável que responda pela criança) e os professores das crianças pivô constituem-se, então, parte dos participantes, pois desconsiderá-los acarretaria em retirar da rede de relações das crianças importantes elementos para a compreensão do fenômeno estudado, como enfatizado na introdução.

Para a definição da participação dos professores levou-se em consideração a estrutura pedagógica da escola e o próprio contexto da educação infantil, que prevê o regente como o professor responsável pelo processo de ensino/aprendizagem da criança nesta faixa etária. Dessa forma, foram considerados participantes os professores regentes de todas as crianças pivôs que se manifestaram positivamente à participação na pesquisa. No que tange à participação dos familiares, considerou-se o familiar que se responsabilizou pelo acompanhamento do desenvolvimento de cada uma das crianças pivôs e que se manifestou de forma positiva à participação na pesquisa.

Intrinsecamente ao processo está a visão participativa do pesquisador, sujeito que escolhe o percurso, que elabora os instrumentos que darão corpo aos dados e que, acima de tudo analisa através de seu próprio processo de pensar, os significados do fenômeno estudado (González-Rey, 2002). A participação do pesquisador pode ser definida dentro do próprio arcabouço teórico-metodológico adotado (Rossetti-Ferreira [et al], 2004), como um ferramenteiro, cuja principal função é construir um percurso investigativo que dê visibilidade à complexidade do fenômeno dentro das suas próprias limitações.

\subsection{Os participantes e o contexto investigado}

Como contexto central da pesquisa estão duas instituições escolares provenientes da Rede Pública de Ensino Regular (uma Municipal e outra Federal) de uma cidade do interior do Estado de Minas Gerais. Foi nesses espaços que o processo de coleta de dados foi realizado ${ }^{23}$.

Oriundas destas duas instituições, foram participantes da pesquisa três crianças com idade entre três e cinco anos, identificadas como crianças com comprometimento no desenvolvimento, tendo recebido o diagnóstico de déficit intelectual. Essas crianças foram aqui denominadas crianças pivô,

\footnotetext{
23 Todas as instituições foram consultadas antes do início da pesquisa e somente a partir da aquiescência do seu representante legal e da aprovação do Comitê de Ética em Pesquisas com Seres Humanos é que a escolha dos participantes foi feita.
} 
denominação atribuída pelo fato de que a construção dos dados é focalizada a partir delas. Porém, como a proposta é apreender as relações dessas crianças na constituição de seu desenvolvimento, além das crianças pivô, foram considerados participantes da pesquisa: familiares (nestes casos apenas as mães se prontificaram a participar da pesquisa, assumindo-se como responsáveis pelas informações disponibilizadas sobre as crianças), seus professores (as professoras regentes das turmas em que as crianças estavam inseridas) e seus pares de idade, ou seja, demais crianças que compartilham do contexto escolar de educação infantil. Na tabela 1 abaixo, constam as informações gerais sobre os participantes.

Tabela 1. - Informações gerais dos participantes da pesquisa

\begin{tabular}{|c|c|c|c|c|c|c|}
\hline $\begin{array}{l}\text { Criança } \\
\text { pivô }\end{array}$ & $\begin{array}{l}\text { Idade/ } \\
\text { sexo }\end{array}$ & Diagnóstico & $\begin{array}{l}\text { Composição } \\
\text { familiar }\end{array}$ & Instituição & $\begin{array}{l}\text { Dados da } \\
\text { professora }\end{array}$ & $\begin{array}{l}\text { Alunos } \\
\text { /sala }\end{array}$ \\
\hline Inácio & $\begin{array}{c}4 \text { ano e } \\
9 \\
\text { meses }\end{array}$ & $\begin{array}{c}\text { *Déficit } \\
\text { Intelectual } \\
\text { associado a } \\
\text { Síndrome de } \\
\text { Down }\end{array}$ & $\begin{array}{l}\text { Filho único, } \\
\text { pais casados. }\end{array}$ & $\begin{array}{c}\text { Federal } \\
\text { com } \\
\text { capacidade } \\
\text { para } 150 \\
\text { crianças na } \\
\text { educação } \\
\text { infantil }\end{array}$ & $\begin{array}{c}31 \text { anos de } \\
\text { idade. } \\
\text { Professora } \\
\text { com } 13 \text { anos } \\
\text { de experiência } \\
\text { docente }\end{array}$ & 19 \\
\hline Ivan & $\begin{array}{l}3 \text { anos } \\
\text { e } 11 \\
\text { meses }\end{array}$ & $\begin{array}{c}\text { *Déficit } \\
\text { Intelectual } \\
\text { associado a } \\
\text { Síndrome de } \\
\text { Down }\end{array}$ & $\begin{array}{l}\text { Pais casados. } \\
2 \text { irmãs mais } \\
\text { velhas. }\end{array}$ & $\begin{array}{l}\text { Federal } \\
\text { com } \\
\text { capacidade } \\
\text { para } 150 \\
\text { crianças na } \\
\text { educação } \\
\text { infantil. }\end{array}$ & $\begin{array}{c}36 \text { anos de } \\
\text { idade. } 3 \text { anos } \\
\text { como } \\
\text { educadora } \\
\text { infantil e } 8 \\
\text { anos de } \\
\text { experiência } \\
\text { docente. }\end{array}$ & 18 \\
\hline Amanda & $\begin{array}{l}3 \text { anos } \\
\text { e } 2 \\
\text { meses }\end{array}$ & $\begin{array}{c}\text { *Déficit } \\
\text { Intelectual } \\
\text { associado a } \\
\text { Síndrome de } \\
\text { Down }\end{array}$ & $\begin{array}{l}\text { Filha do } \\
\text { segundo } \\
\text { casamento } \\
\text { da mãe Pais } \\
\text { casados. } \\
\text { Uma irmã } \\
\text { mais velha } \\
\text { (15 anos) }\end{array}$ & $\begin{array}{l}\text { Municipal } \\
\text { com } \\
\text { capacidade } \\
\text { para } 1000 \\
\text { crianças na } \\
\text { educação } \\
\text { infantil. }\end{array}$ & $\begin{array}{l}26 \text { anos de } \\
\text { idade. } \\
\text { Professora } \\
\text { com } 5 \text { anos de } \\
\text { experiência, } \\
\text { mais duas } \\
\text { educadoras }\end{array}$ & 29 \\
\hline
\end{tabular}

Nota: * Apesar de todos os casos dentro do estudo terem associado ao déficit intelectual a Síndrome de Down, julga-se importante ressaltar que esse não foi um critério de inclusão para a pesquisa. Há uma coincidência nos diagnósticos dos casos selecionados.

Cabe aqui destacar que, as duas escolas apresentam estruturas físicas e institucionais diferentes. A escola de Inácio e Ivan não é específica para Educação Infantil e prevê a continuidade do processo de escolarização dos seus alunos até o final do Ensino Fundamental. A escola está sob vigência jurídica e administração orçamentária da esfera federal de ensino, pertencente a uma Instituição de Ensino Superior da Rede Pública. Já a escola de Amanda, pertence ao sistema Municipal de Ensino Público e, portanto, funciona sob a legislação municipal e a administração também correspondente. 
Dessa forma, a organização da rotina institucional também se estrutura de acordo com essas distintas condições e pode influenciar na possibilidade de interação das crianças.

\subsection{Instrumentos e caminhos para construção do corpus}

Como primeiro passo para a efetivação do processo de coleta de dados dentro da perspectiva da RedSig (Rossetti-Ferreira, Amorim \& Silva, 2004) está o “mergulho” do pesquisador no campo de estudo. Esse elemento configura-se como imprescindível para pesquisas sobre desenvolvimento humano em decorrência de se considerar inerentes ao processo fatores sociais e históricos. Para a presente pesquisa, esse mergulho da pesquisadora no campo de estudo aconteceu ao longo de três anos anteriores ao início da pesquisa, durante o trabalho desenvolvido pela pesquisadora junto a instituições de educação infantil. E, a partir desse contato prévio, tendo maior conhecimento sobre o contexto, foi possível delinear o percurso para a coleta de dados e escolher os recursos com os quais esse trabalho seria efetivado.

Para o processo de construção dos dados foram escolhidos três tipos de instrumentos de coleta: a entrevista, a observação vídeo-registrada e o diário de campo. As entrevistas, realizadas exclusivamente com os participantes adultos, foram pensadas dentro da perspectiva de uma entrevista semi-estruturada (Szymanski, 2004). Com a permissão dos participantes, elas foram áudio registradas com o objetivo de facilitar o processo de reflexão e análise, garantindo que todas as falas pudessem ser retomadas posteriormente, sem modificações em função de problemas de memória.

A entrevista é reconhecida aqui como um momento de interação social, trazendo na fala critérios de representatividade e, dessa forma, apresentando dados tanto de natureza objetiva (fatos concretos, objetivos e etc.), quanto de natureza subjetiva (atitudes, valores, crenças e etc.) (Minayo, 1996). A entrevista representa um instrumento que tem sido empregado em pesquisas qualitativas, em todas as áreas de conhecimento, como uma contribuição para o estudo de significados subjetivos e complexos demais para serem abordados por outros recursos (Banister et al., 1994 como citado em Szymanski, 2004).

Minayo (1996) afirma ainda que cada indivíduo é um ator social, que experimenta e conhece o fato social de forma peculiar e sendo o conjunto das diferentes informações individuais, vivenciadas em comum por um grupo, que permite compor um quadro mais global das estruturas e das relações, buscando compreender os modelos culturais e a particularidade de algumas das determinações socioculturais. Por meio das entrevistas, foi possível ter acesso a informações que auxiliaram na compreensão do contexto social em que as crianças estão imersas, bem como elementos da sua história de vida e de desenvolvimento anteriores a esse momento de escolarização. Esses dados foram 
considerados de grande relevância para composição da rede de significações constituidora do desenvolvimento dessas crianças.

O diário de campo foi utilizado enquanto instrumento de registro de percepções e ideias da pesquisadora, quando em campo. No diário foram registrados pensamentos e percepções que auxiliaram a pesquisadora a retornar à cena observada, sistematizar o seu envolvimento no processo de observação e registrar elementos que revelam o movimento do processo de coleta de dados. Os diários de campo têm sido utilizados e descritos, enquanto ferramenta para coleta de dados, principalmente em estudos no campo da antropologia. Contudo, diferentes estudos apontam estratégias para a utilização desse recurso em outros campos de conhecimento (Clayton \& Thorne, 2000; Nadin \& Cassell, 2006).

As videogravações foram destinadas à coleta junto às crianças e aquelas se configuram como o instrumento principal do presente estudo. A opção foi pelas videogravações, pois acredita-se que o vídeo registro seja o recurso mais adequado para acompanhar e documentar os processos de interação entre as crianças, uma vez que, através deste, é possível lançar um grande número de olhares que possam vir a contribuir para a análise dos sujeitos em ação. A escolha por esse recurso se sustenta em pesquisas anteriores cujo foco também eram os processos interacionais (Souza \& Batista, 2008; Carvalho, Branco, Pedrosa \& Gil, 2002; Pedrosa \& Carvalho, 2005; Odegarard, 2012; Pálmadóttir, 2012). Além disso, segundo Ferreira (2005), a videogravação se apresenta como um interessante instrumento para capturar dados em pesquisas com crianças, haja visto a complexidade envolvida na análise de fenômenos humanos na infância.

No caso deste estudo, em que se prioriza o processo interacional, o vídeo registro permite o acompanhamento de cenas, o retorno ao evento registrado e a análise de diferentes elementos que contribuem para a compreensão geral do processo. Para além, o vídeo registro permite também o acesso à expressão comunicativa das crianças que não necessariamente já adquiriram a linguagem verbal, ampliando as possibilidades de análise das interações de pares e privilegiando um entendimento sobre os processos comunicativos que envolvem o corpo, os gestos e as expressões, conforme já mencionado na introdução desse trabalho.

Com relação ao que tange os momentos em que esses dados foram coletados, os mesmos foram organizados em dois momentos distintos de investigação.

\section{Primeiro momento - entrevistas e diário de campo.}

Para ser possível estabelecer elementos para o processo de observação, ao longo da construção dos dados, entende-se ser imprescindível que se conheça a história desses sujeitos e a condição em que cada um se encontra em relação ao seu processo de desenvolvimento. Esse preâmbulo não é 
necessário para se obter parâmetros de comparação entre as crianças, mas para que seja possível compreender os elementos relacionados a cada uma dessas crianças presentes no ambiente escolar. No mesmo sentido, se buscou caracterizar o ambiente escolar no qual essas crianças estão inseridas; as concepções pedagógicas que orientam o trabalho docente, a construção do espaço escolar e a forma como os profissionais da educação entendem o desenvolvimento da criança com deficiência, delineia os processos interativos dos pares e interfere diretamente no percurso vivencial individual.

Para tanto, foram realizadas entrevistas com todas as mães e professoras regentes de cada uma das crianças pivô. Essas entrevistas foram realizadas no início do processo de coleta de dados e ao final do ano letivo, depois de encerrada a coleta com os vídeo-registros. $\mathrm{Na}$ entrevista inicial com as mães buscou-se conhecer o percurso de desenvolvimento de cada criança com déficit intelectual, sua história de vida, suas experiências de aprendizagem ao longo da primeira infância e as principais relações estabelecidas pela criança, desde o nascimento. Na entrevista ao final do processo, abordouse questões ligadas à percepção das mães sobre o desenvolvimento das crianças e sobre os processos interacionais com os demais colegas em sala. Todas as entrevistas foram realizadas tendo como suporte um roteiro com os principais pontos de interesse da pesquisa (anexo A). As entrevistas, que duraram cerca de quarenta minutos cada, foram realizadas em ambientes (casa, escola ou local de trabalho) e horários escolhidos pelos próprios participantes.

Com os professores, também se procedeu de forma semelhante. Foram agendados horários e disponibilizada, aos participantes, a escolha do local que melhor lhes conviesse. A entrevista, também semiestruturada, foi áudio registrada e teve em média a duração de cerca de cinquenta minutos cada. O roteiro (Anexo B) foi pensado para suscitar discussões acerca de concepções sobre déficit intelectual, percepções sobre o processo de escolarização da criança com déficit, os princípios que norteiam as estratégias pedagógicas e os elementos referentes à organização das relações, dos espaços e tempos na escola, entre outros pontos. $\mathrm{Na}$ entrevista realizada ao final do ano letivo, as professoras foram solicitadas a falarem sobre suas percepções sobre o desenvolvimento da criança com deficiência e sobre as relações estabelecidas pela criança pivô com os pares, na sala de aula.

Através desse conjunto de entrevistas (com familiares e profissionais), representações sobre o que é infância, déficit intelectual, o que é e como é a escola para essa criança, bem como, quais são as percepções sobre o processo de desenvolvimento e de interações sociais para essas crianças, emergiram. Esses elementos contribuem para constituir a história do sujeito. No caso deste estudo, da criança com déficit intelectual e ajudam a compreender algumas das situações de interação no contexto estudado. Esse material explicita elementos que compõem uma rede de significados que deve ser considerada no processo de análise do desenvolvimento humano em questão (Rossetti- 
Ferreira, Amorim \& Silva, 2004). Ao longo desse processo, registros pessoais compuseram os primeiros pontos de reflexão do diário de campo.

\section{Segundo momento - vídeo gravações dos processos interacionais e diário de campo}

Em um segundo momento de coleta de dados do processo de investigação (cabendo aqui destacar que não se trata de uma marcação temporal, mas didática), estão as observações vídeo registradas com os grupos de crianças, no contexto da educação infantil.

Iniciando no mês de março (Inácio e Ivan) e maio (Amanda) de 2014, foram realizados semanalmente vídeo registros das três crianças identificadas como crianças com déficit intelectual pelas Instituições de Educação Infantil participantes na pesquisa. Inicialmente, considerou-se priorizar apenas registros de momentos e espaços onde a brincadeira livre e a construção da autonomia fossem centro do processo, justamente por corroborar com a ideia de que ambos espaços/situações (de ludicidade e construção da autonomia) constituem-se como principais oportunidades para a criança, espontaneamente, construir sentido sobre o ambiente e as experiências vividas. A ludicidade, a brincadeira, os jogos de faz de conta e a representação de papéis, ilustram situações que estão diretamente relacionadas com o desenvolvimento integral da criança nesta faixa etária, principalmente no que diz respeito à criação e organização de recursos cognitivos necessários para os processos interacionais e, consequentemente, para a apropriação dos elementos culturais, como discutem alguns autores (Kishimoto 1995, 1996, 2001). Entretanto, após contato direto no contexto de pesquisa, observou-se que a diversidade da rotina escolar possibilitaria um olhar mais ampliado para a compreensão do processo de construção dessas interações de pares.

Assim, os vídeo-registros aconteceram na totalidade no espaço escolar regular, em diferentes momentos da sua rotina e cotidiano como, por exemplo, atividades orientadas em sala de aula, atividades de contação de história, aula de educação física, lanche, atividade livre no pátio, aula de arte, biblioteca e brinquedoteca. O uso da câmera também foi pensado de acordo com os objetivos de apreensão dos processos interacionais e, tendo como referência estudos anteriores que consideraram diferentes estratégias de registro por vídeo (Jewitt, 2012), optou-se pelo registro manual, sem suporte fixo e que acompanhasse o movimento da criança pivô por todos os espaços.

O diário de campo, que funcionou como um suporte de memória dos principais acontecimentos daquele dia de gravação, foi construído imediatamente após os registros de vídeo, enquanto as notas pessoais, impressões, reflexões e questionamentos adicionais feitos pela pesquisadora durante o momento de coleta de dados ainda estavam vivos na experiência da observação e registro por vídeo. 


\subsection{Percursos e abordagem para a análise dos dados}

Para proceder com as análises dos dados, também se considerou a diversidade de instrumentos e o objetivo do uso de cada um deles. Iniciou-se pela análise das entrevistas dos familiares e professores, realizadas no início da coleta de dados, em abril de 2014. Por esse material foi possível fazer a composição geral da história de vida de cada uma das crianças pivô e ter acesso a um panorama dos contextos escolares em que os participantes estavam inseridos.

Para as análises, foram considerados como materiais os áudios provenientes das entrevistas, de onde as informações foram diretamente retiradas e organizadas em categorias diferentes. Das entrevistas com os familiares (mães), cinco tipos de informações foram buscadas: (1) a composição familiar; (2) o histórico ao longo da gravidez; (3) os registros de intercorrências médicas ao longo da primeira infância; (4) os principais aspectos relatados sobre o desenvolvimento da criança ao longo dos primeiros anos de vida; e, (5) as experiências escolares anteriores. Das entrevistas com os professores, outro conjunto de informações foi analisado: (1) a concepção do que seja déficit intelectual; (2) a formação/experiência profissional para o trabalho junto ao aluno com déficit intelectual; (3) o planejamento pedagógico para organização do trabalho com o aluno com déficit intelectual; e, (4) as expectativas com relação ao desenvolvimento e à aprendizagem da criança com déficit intelectual.

As informações foram compondo uma descrição do cenário familiar e escolar da criança, auxiliando a compreensão de algumas das dinâmicas envolvendo cada uma delas. Todas as informações coletadas ao longo desse processo estão descritas e explicitadas na descrição dos estudos de caso, mais precisamente na caracterização dos casos, no capítulo em que são descritos os resultados.

Posteriormente, deu-se início ao processo de análise dos vídeo-registros - principal material de análise desse estudo. O primeiro passo para prosseguir com as análises foi a edição de cenas que continham crianças cujos pais não autorizaram a participação na pesquisa ou cenas em que a criança pivô encontrava-se em lugares privativos (e.g., banheiro). Em seguida, para a análise dos dados dos vídeo-registros foram adotados dois procedimentos distintos: (1) o mapeamento dos episódios de interação em três diferentes fases e com enfoques distintos; e, (2) a análise microgenética de episódios selecionados em diferentes momentos da coleta de dados. Embora tenham finalidades distintas, ambos procedimentos se complementam, possibilitando que tenhamos tanto uma perspectiva ampla dos dados coletados, quanto uma visão micro dos processos de interação registrados. Tal composição metodológica é inspirada em outros estudos sobre desenvolvimento humano (Carvalho, ImpérioHamburger \& Pedrosa, 1996; Carvalho \& Rubiano, 2004; Dell'Isola, 2013; Moura, 2013; Pedrosa \& Carvalho, 2006;) 


\section{Fase I - Mapeamento dos contatos corporais.}

Retomando a noção de interação adotada neste trabalho, corrobora-se com o entendimento de que interação, em seu sentido mais amplo, é dialógica e tem um fluxo contínuo que não permite uma visão em que o fato interacional terá um recorte estanque (Branco et.al.,1989). Dentro dessa perspectiva, Carvalho, Império-Hamburgo e Pedrosa (1996) definem um campo interativo como sendo composto por elementos como espaço físico, tempo, sujeitos, objetos, ações e etc.; ainda, é definido pela natureza dessas partes que interagem, ao mesmo tempo que as constitui num movimento irregular e incessante. Isso significa que a interação é definida por "um potencial de regulação entre componentes do campo social" (Carvalho, Império-Hamburgo \& Pedrosa, 1996, p. 4), composto por relações em que há um potencial trânsito de informações (construçãolcompartilhamento de significado) entre os sujeitos que, por sua vez, o compõem. Tais trânsitos podem inclusive se dar sem que um dos participantes se dê conta de que esteja regulando o comportamento de outro. Contudo, o contato físico comporia, nessa perspectiva, um dos elementos que possivelmente demarca o movimento da criança na seleção do outro como foco de sua própria atenção (princípio da orientação da atenção), indicando um potencial de regulação (Carvalho \& Rubiano, 2004).

Dessa forma, nessa primeira fase de análise, optou-se por utilizar o contato físico como evidência comportamental para o recorte dos episódios interativos. Os primeiros passos para essa análise foram a identificação e quantificação (mapeamento) desses contatos corporais entre as crianças pivô e seus pares ao longo das gravações coletadas, tendo como inspiração procedimentos adotados em estudos anteriores (Carvalho, Império-Hamburger \& Pedrosa, 1996; Pedrosa \& Carvalho, 2005). O mapeamento dos episódios se deu quando identificado o contato físico, considerando todo e qualquer toque intencional ${ }^{24}$ realizado pelas crianças envolvendo a criança pivô, podendo esse contato desencadear (ou não) regulações e corregulações de comportamentos subsequentes dos sujeitos envolvidos. No caso dos episódios de interação onde houve corregulações de comportamento subsequentes, contabilizou-se apenas o contato físico que deu início ao processo e considerou-se os demais contatos como parte desses processos de corregulações.

A partir do procedimento de mapeamento, em que foi quantificado o número de episódios (ainda dentro de uma perspectiva de análise qualitativa), verificou-se o aumento ou a diminuição de interações ao longo do tempo; quais foram os espaços e contextos escolares em que se observou maior/menor interação entre as crianças; e, quais foram as crianças que mais estabeleceram interação com a criança pivô. Essas informações auxiliaram na compreensão da dinâmica do contexto escolar,

\footnotetext{
${ }^{24}$ Tropeços ou esbarrões acidentais não foram contabilizados. Situações em que a criança usa objetos como extensão de seu próprio corpo para alcançar ou para manter contato com o outro foram contabilizadas'.
} 
na identificação de possíveis pares preferenciais e na compreensão do papel do contato físico na construção dos processos interativos, buscando construir subsídios para a discussão dos processos de desenvolvimento das crianças com déficit intelectual.

\section{Fase II - Mapeamento e microgenética das regulações de comportamento}

Neste segundo momento, o enfoque da análise recaiu sobre as regulações de comportamento. Foram considerados, a partir dos dados do mapeamento da fase anterior, todos os episódios em que os contatos físicos caracterizavam-se pelo próprio comportamento regulado, ou se os contatos corporais eram os fatores reguladores. Para além, nesta fase, todos os vídeos foram reanalisados, buscando-se identificar episódios de regulação de comportamento em situações sem nenhum contato físico, reforçando a compreensão de que a interação não se restringe apenas a situações em que há contato físico entre indivíduos. Ao contrário, o que caracteriza o processo de interação é a possibilidade da regulação e corregulações de comportamento dentro do campo interacional; uma sequência de ações de um indivíduo que, originárias de uma ação (ou um conjunto de ações) de outro (ou de um grupo), explicitam um mesmo conteúdo ou contexto, indicando que (mesmo sem intencionalidade), um indivíduo pode influenciar a ação de outro num dado contexto, criando uma situação interacional (Carvalho, Império-Hamburgo \& Pedrosa, 1996). Dentro dessa perspectiva de análise, dois elementos foram levados em consideração para o recorte dos episódios: o compartilhamento de objetos e a atenção conjunta.

\section{A regulação de comportamento com atenção conjunta elou compartilhamento de objeto}

O elemento diferido na regulação de comportamento com compartilhamento de objeto ou atenção conjunta é justamente a existência da atenção conjunta ou a troca explícita no compartilhamento de objetos. A atenção conjunta tem sido definida como a habilidade que envolve a coordenação da atenção entre um parceiro social e um objeto ou situação de interesse mútuo (Tomasello, 1995). Embora Vygotsky (2007) já apontasse que a habilidade para focalizar a própria atenção é um fator determinante no sucesso (ou não) de operações práticas, destacando a atenção como uma relevante estrutura psicológica que embasa o uso de instrumentos num contexto social, foi no estudo sobre comunicação e sobre as ações não verbais contidas nas rotinas de interação entre mães-bebês de Bruner (Bruner, 1975; Ninio \& Bruner, 1978), que elementos definidores da atenção conjunta e sua função no desenvolvimento humano foram mais claramente formulados.

A aquisição dessa habilidade é considerada um dos principais marcos na infância, visto que impulsiona a participação ativa da criança em contextos de aprendizagem sociocultural (Bruner, 1973; 1980; Mundy, Card \& Fox, 2000). Aponta-se que, desde a década de 1980-1990 (Bakeman \& 
Adamson, 1984; Butterworth, 1995; Bruner, 1983; Tomasello \& Farrar, 1986), essa habilidade, às vezes expressa simplesmente a partir de comportamentos como, por exemplo, seguir o olhar do outro ou olhar na mesma direção para onde o outro está olhando, favorece a comunicação referencial durante as interações entre o adulto e a criança, permitindo o surgimento gradativo de gestos de caráter sociocomunicativo e simbólico, tais como o ato de apontar.

Por uma diferente perspectiva de análise, mas também contribuindo para a presente discussão, Reddy (2012) afirma que, no que tange à compreensão de como crianças pequenas constroem sentido do mundo em que habitam, encontram-se evidências - desde uma tenra idade - desse processo de observação do comportamento de outros. Nesse sentido, a autora afirma que mesmo em bebês a leitura desse comportamento perpassa a interpretação das intenções captadas pelas expressões corporais e faciais bem como pelo desenvolvimento de ações ao longo de um período de tempo em determinado espaço. A leitura refinada das intenções e das respostas do outro que resulta em parâmetros para o próprio comportamento do indivíduo que o observa é, para Reddy (2012) a chave para o processo de significação de mundo tão singular na espécie humana.

Mais especificamente, quando se discute sobre a tríade indivíduo-objeto-indivíduo em situações com a criança com deficiência, particular interesse tem sido dado à atenção conjunta em crianças com autismo, enfatizando a relação direta entre o desenvolvimento da linguagem (fala) e das habilidades sociais e a incidência de atenção conjunta (Jones \& Carr, 2004; Legerstee \& Weintraub, 1997). Contudo, no que tangencia a atenção conjunta em crianças com déficit intelectual, apesar de se constatar uma diferença quantitativa na incidência de situações em comparação a crianças sem o déficit. Esses estudos apontam que o interesse pelo outro e a capacidade de engajamento na ação do outro, desempenham papel fundamental para a ocorrência da atenção conjunta, elemento que se diferencia dos casos de autismo (Kasari, Sigman, Mundy \& Yirmiya, 1990).

\section{A regulação de comportamento sem compartilhamento de objeto e atenção conjunta}

A regulação de comportamento sem compartilhamento de objeto ou atenção conjunta acontece quando a açãolmovimento de um membro do campo social regula o comportamento de outro, sem que neste processo tenha havido troca explícita de informação, partindo do pressuposto de que o "processo de regulação dos indivíduos envolvidos não requer reciprocidade explícita" (Carvalho, Império-Hamburger \& Pedrosa, 1996, p. 8). Tal situação é explicada pelo primeiro princípio da sociabilidade para a espécie humana: a orientação da atenção pela presença do outro. Isso significa que a atenção, enquanto processo que identifica e seleciona aspectos mais relevantes do meio, orientase primariamente pela presença de outro da mesma espécie (Carvalho, Império-Hamburger \& Pedrosa, 1996). 
Embora os elementos elencados - compartilhamento de objeto e atenção conjunta - não sejam os únicos indícios para se identificar um episódio de interação, eles abrem espaço para uma compreensão sobre a construção das relações de grupo no contexto escolar e auxiliam no momento de escolha de episódios para a condução da análise microgenética (discutida mais adiante). Julga-se pertinente destacar que, para proceder com essa análise, focou-se em como as regulações foram construídas, por qual tipo de movimento a interação iniciou, que ações a suscitava, como o outro respondia (se respondia) e que ações eram desencadeadas a partir disso. Essas cenas foram organizadas por meio de esquema gráfico em formato de mapa com um resumo que indicava o conteúdo de cada uma delas. Essa estrutura permitiu que a pesquisadora identificasse quais eram os contextos e as dinâmicas envolvidas em cada um dos dias de gravação.

De uma forma geral, as regulações aconteceram em diferentes situações (e.g. atividades coletivas orientadas por um adulto, atividades lúdicas livres, momentos de refeição, momentos de descanso, dentre muitos outros) que, no modo como se efetivavam, compõem duas categorias: (1) regulação de comportamento sem compartilhamento de objetos ou atenção conjunta; e, (2) regulação de comportamento com compartilhamento de objetos ou atenção conjunta. Abaixo encontra-se uma tabela 2, que descreve os comportamentos observáveis utilizados para a categorização supracitada.

Tabela 2. - Descrição dos comportamentos observáveis utilizados para categorizar as regulações de comportamento no processo de mapeamento dos episódios de interação.

\begin{tabular}{cl}
\hline Comportamento & Descrição \\
\hline Compartilhamento de objetos & - Troca de objetos \\
& - Utilização conjunta de objetos \\
& - Divisão de objetos \\
& - Construção conjunta de objetos \\
& -Direcionamento visual unilateral conjunto para um mesmo \\
Atenção conjunta & objetolpessoalsituação (criança A e criança B olham para um mesmo objeto ao \\
& mesmo tempo, mas não trocam olhares entre si) \\
& - Direcionamento visual bilateral conjunto para um mesmo \\
& $\begin{array}{l}\text { objetolpessoal situação (criança A e criança B olham para um mesmo objeto ao } \\
\text { mesmo tempo trocando alternadamente olhares entre si). }\end{array}$
\end{tabular}

Ainda na fase II, além de mapear e quantificar a incidência dos comportamentos regulatórios, foi realizada a análise microgenética de diferentes situações de regulação em todos os três estudos de caso. A análise microgenética é considerada:

“(...) uma forma de construção de dados que requer a atenção a detalhes e o recorte de episódios interativos, sendo o exame orientado para o funcionamento dos sujeitos focais, as relações intersubjetivas e 
as condições sociais da situação, resultando num relato minucioso dos acontecimentos. Frequentemente, dadas as demandas de registro implicadas, essa análise é associada ao uso de vídeo gravação, envolvendo o domínio de estratégias para a filmagem e a trabalhosa atividade de transcrição" (Goés, 2000 p. 9).

Wertsch (1985, como citado em Góes, 2000) define a análise microgenética como o método de descrição minuciosa e contínua dos elementos que caracterizam ou estruturam um processo, situação ou fenômeno, remetendo para isso as ações e interações dos sujeitos que dele participam. Esse tipo de análise utilizado em diferentes estudos na Psicologia (Anjos, Amorim, Franchi e Vasconcelos \& Rossetti-Ferreira, 2004; Barbosa \& Zanella, 2005; Scorsolini-Comin \& Amorim, 2010; Monteiro \& Freitas, 2014) tem dado contribuição particular para estudos cujo foco seja a constituição do sujeito e os processos de desenvolvimento humano. A análise microgenética é, segundo Góes (2000), um processo pelo qual se busca identificar as origens, a gênese dos processos em análise. Ela afirma que para a busca das unidades de análise é necessário o contato profundo com o material empírico, partindo desse olhar às minúcias, aos detalhes, às pistas, aos aspectos relevantes no curso desse processo. Da mesma maneira, para a eleição dos episódios em que foram realizadas as análises, definiu-se pelo estabelecimento de relação clara com o tema de interesse, pois será a partir deste que “os episódios típicos ou atípicos permitem interpretar o fenômeno” (Góes, 2000, p. 21).

Com essa análise, permitiu-se entender os processos ou as qualidades contidas nas quantidades; pôde-se explorar os conteúdos das interações, o papel da regulação (e corregulações) de comportamento para a construção de atividades conjuntas de pares e suas possíveis relações com as aprendizagens em contexto institucional escolar. Esses dados possibilitaram reflexões sobre o tema central deste trabalho - a criação de Zona de Desenvolvimento Proximal na interação de pares.

\section{Fase III - Análise microgenética das corregulações de comportamento ao longo do tempo}

Na terceira e última fase, os mapeamentos da fase II que continham os resumos dos conteúdos das cenas de interação foram novamente analisados, selecionando-se apenas episódios que continham corregulações de comportamento em situações de compartilhamento de objeto ou atenção conjunta. A partir do conjunto total de dados, foram conduzidas análises microgenéticas em episódios de interação específicos provenientes de três momentos diferentes de coleta de dados, começo, meio e fim (de acordo com cada estudo de caso). Dessa forma, a análise microgenética adotada na "fase III" é feita dentro de um recorte de tempo específico, considerando as ações (e inter-relações) dos sujeitos que participam do campo interacional observado. O objetivo dessa análise foi identificar a origem e 
os movimentos que desencadeiam essas ações, bem como as reações e as transformações presentes nesse momento (mesmo que breve). Esse processo foi conduzido através do olhar e (re)olhar o material registrado, por isso a importância do vídeo-registro, que permite ao pesquisador voltar ao material quantas vezes necessário.

Esse procedimento foi implementado em decorrência dos resultados da fase II que indicaram serem as situações de corregulações de comportamento com compartilhamento de objeto ou atenção conjunta, condições privilegiadas para o estabelecimento de processos de aprendizagem. O objetivo da análise na fase III configurou-se, portanto, na compreensão do papel da temporalidade para a interação de pares, focalizando nas possíveis transformações na forma como as interações de pares se constituíram, possibilitando (ou não) diferentes processos de aprendizagem.

Ao final das análises, retomando as orientações teórico-metodológicas da RedSig que fundamentam esse estudo (Rossetti-Ferreira, Amorim \& Silva, 2004), todos os dados são entrelaçados (colocados simultaneamente em diálogo) e foi dentro dessa perspectiva complexa e multifatorial que o tema - a ZPD na relação de pares - foi debatido.

Julga-se pertinente destacar que, conforme afirmam Carvalho, Império-Hamburguer e Pedrosa (1996) sobre o processo de análise de vídeo-registros, "as indicações que orientam o observador ao recortar a sequência são o espaço, o tempo e a expectativa de identificar pistas sobre a natureza das regulações que ocorrem nesse campo de interações" (p.7). Desse modo, para manter-se o foco no objetivo do trabalho dentro da imensidão de dados, o olhar sobre o conteúdo do material demandou, paralelamente, a leitura das notas tomadas no diário de campo e a retomada das informações provenientes do material coletado nas entrevistas, principalmente aquelas feitas com os professores dos alunos com déficit intelectual.

Considera-se importante destacar que, ao longo das três fases de análises, muitos episódios identificados pelos processos de mapeamento não foram inseridos neste trabalho em nenhuma das fases descritas. Recortes de interação que contém atividades conjuntas diversas, com conteúdo significativo e interessante poderão ser usadas em futuras análises relativas à discussão sobre o processo de desenvolvimento ou escolarização de crianças com déficit intelectual. 


\section{Resultados}

A apresentação dos resultados de um estudo qualitativo em que há grande quantidade de material analisado configura-se como um desafio para o pesquisador que deseja explicitar a compreensão do seu processo investigativo. Dessa forma, com a finalidade de melhor organizar essa apresentação, os resultados e as análises seguirão a sequência em que o próprio processo de análise dos dados foi realizado.

Assim, esse capítulo inicia-se pela descrição das características que as famílias julgam serem mais relevantes em relação a seus filhos. Os dados são resultados provenientes das entrevistas com as mães das crianças pivô, em que as mesmas puderam contar a história de vida, particularidades do processo de desenvolvimento e especificidades de cada uma das crianças.

Logo em seguida apresentamos a descrição do contexto escolar, com informações sobre os aspectos pedagógicos da instituição, as percepções das professoras sobre os alunos pivôs e a participação dos mesmos na composição do contexto escolar. Apresenta-se também uma descrição mais detalhada da Instituição Educacional, tais como: características pedagógicas, provenientes das informações oferecidas pelas professoras e pelos registros públicos disponibilizados no site da escola; a formação/experiência profissional para o trabalho junto ao aluno com déficit intelectual; a concepção do que seja déficit intelectual; o planejamento pedagógico para organização do trabalho com o aluno com déficit intelectual; e, as expectativas com relação ao desenvolvimento da criança com déficit intelectual. Cada contexto será apresentado a partir da identificação de cada caso estudado.

Posteriormente, apresentam-se os resultados provenientes das diferentes fases de análise. Para cada fase de análise, os dados são disponibilizados respeitando o percurso individual de desenvolvimento das crianças, significando que são apresentados resultados caso a caso, fase a fase. Entretanto, na tentativa de garantir essa singularidade, mas, ao mesmo tempo, demonstrar como os elementos discutidos podem ser tanto mais aproximados ou distanciados dentro de uma perspectiva mais ampla de análise, ao final de cada fase de análise (fases I, II e III) apresenta-se um subcapítulo de reflexões. Essas reflexões visam fazer o elo entre os casos em cada uma das fases de análise, uma vez que, por se respeitar a individualidade e a peculiaridade dos processos de desenvolvimento não exista um padrão pré-definido de apresentação dos dados; foi a forma encontrada para explicitar os diferentes caminhos de aprendizagem e desenvolvimento que compõem o fenômeno em estudo.

As informações provenientes dos diários de campo são mencionadas ao longo de todo o processo de apresentação dos dados e das análises feitas. Quando necessário, fazem-se destaques sobre esse recurso. 


\subsection{Entrevista com os familiares: entendendo a história de cada sujeito.}

\section{Estudo de caso Inácio}

Inácio é um menino que tinha quatro anos e nove meses quando do começo das videogravações. Inácio tem Síndrome de Down, com prevalência do déficit intelectual. Ele é filho único, nasceu em uma família constituída pela mãe que tem descendência nordestina e pai com descendência japonesa. O casal tentou por mais de cinco anos engravidar, realizando inúmeros tratamentos para fertilização. Quando já haviam parado de tentar a fertilização e já estavam em busca de outras formas de terem um filho, descobriram que estavam grávidos.

A gestação foi acompanhada com pré-natal mensal, mas em nenhum dos exames feitos foi detectada a Síndrome de Down. Dessa forma, todo o planejamento durante a gestação foi na expectativa de ser um menino sem nenhuma síndrome. Mesmo nas primeiras consultas ao pediatra, o diagnóstico não foi feito, até mesmo por se tratar de uma família com descendência japonesa. Além disso, devido a descendência japonesa a aparência de Inácio nunca foi interpretada enquanto sinais físicos que são diretamente relacionados à Síndrome de Down. O quadro só foi definido a partir da detecção de alteração genética, no processo de investigação dos problemas de alergia e refluxo da criança. A pediatra solicitou o mapeamento genético e, quando da confirmação do diagnóstico, ela avisou a família. A mãe afirma que teve bastante dificuldade em lidar com o diagnóstico, mas que nunca manteve o filho em casa, nem o privou de qualquer contato social em decorrência disso. Sempre levou Inácio a todas as consultas médicas e aos atendimentos complementares que lhe foram solicitados (fisioterapia, fonoaudióloga, terapia ocupacional, psicóloga e natação para a tonificação da musculatura).

Ainda sobre situações médicas e intervenções clínicas, Inácio passou por um procedimento de retirada de vesícula aos dois anos de idade e, atualmente, faz acompanhamentos regulares para controlar os problemas gástricos acarretados pelo refluxo e alergia. A alimentação de Inácio é restrita em decorrência das alergias. A mãe refere que ele não é uma criança que come muito, mas que, dentro da sua limitada dieta, ele se alimenta em níveis satisfatório. A família ainda investiga todas as alergias de Inácio. Até o presente momento, é sabido que ele tem alergia a proteína do leite, a temperos diversos (cebola, pimenta, alho, caldo de galinha industrializada), a feijão e ao glúten. Essa situação coloca a família em constante estado de vigilância com a criança, toda a sua alimentação sendo monitorada para que, caso ele passe mal, possa ser identificada uma possível causa.

O sono de Inácio é descrito pela mãe como "bastante complicado", já que ele não dorme a noite inteira, permanecendo acordado por longos períodos, apenas tirando pequenos cochilos. Isso acontece em decorrência do problema de refluxo da criança que o impede de permanecer deitado, 
mesmo com um colchão inclinado. Aliado a isso, Inácio tem muitas cólicas pois o PH do seu estômago fica muito ácido, causando dor e também fazendo com que acorde durante a noite. A família investiga agora a possibilidade de corrigir cirurgicamente o desvio que causa o refluxo e aguarda o exame de phmetria para saber se essa cirurgia resolve ou não o problema. Apesar disso, Inácio vai para a escola com disposição e consegue permanecer na instituição sem a necessidade de dormir.

Inácio apresenta ainda uma perda auditiva leve, o que demanda o uso de aparelho auditivo. Porém, segundo a mãe, colocar esse aparelho em Inácio tem sido um desafio, pois é um dispositivo caro ( $\mathrm{R} \$ 6.000,00$ Reais) e a criança, em diversas situações, já retirou o aparelho para poder dar para o cachorro brincar.

Com relação aos processos de aprendizagem de Inácio em casa, a mãe descreve a criança como muito esperta. De acordo com a mãe, ele já sabe ir ao banheiro sozinho, embora necessite auxílio para a higiene pessoal adequada; ele come sozinho e entende tudo o que a mãe solicita que ele faça. Esses comportamentos são denominados pela mãe como ações que possibilitam independência a Inácio e são reconhecidos como sendo decorrentes da sua exclusiva dedicação ao filho.

A mãe afirma também que, na família, a criança tem contato com todos os tios, primos e avós, que nunca manifestaram nenhum tipo de descriminação em relação à criança. Entretanto, ela diz que reconhece que os seus parentes ainda não estão preparados para contribuir no processo de educação de Inácio. A mãe narra a dificuldade dos avós e tios em lidar tanto com as questões médicas de Inácio (referindo-se ao refluxo e as alergias), quanto com seus comportamentos atípicos (referindo-se principalmente ao comportamento dele de jogar coisas quando está nervoso; ainda, ao fato de ele não conseguir falar, comunicando-se mais por gestos e vocalizações mais guturais). Quando questionada sobre o contato de Inácio com outras crianças, a mãe refere que ele mantém contatos com outros membros da família, interage com outras crianças fora do contexto escolar e familiar. Porém, ela afirma que esses contatos são poucos, pois ele não tem primos da mesma idade e mora em um condomínio que não tem tantas crianças.

De uma forma geral, o desenvolvimento de Inácio é identificado pela mãe como melhor do que o esperado. Apesar de se identificar uma necessidade de melhora na coordenação motora fina e na aquisição da linguagem verbal, Inácio mostra grande interesse em aprender as coisas que lhes são apresentadas.

A mãe relata que a comunicação verbal do filho é bastante comprometida, sendo que apenas com três anos e meio é que ele começou a vocalizar sílabas e a tentar falar palavras. No dia-a-dia, ele gosta muito de bolas, massinha de modelar e brinquedos de montar. A atividade de montagem de peças do brinquedo é, muitas vezes, complicada, pela dificuldade na coordenação motora fina. A 
maior expectativa da mãe é a independência de Inácio na sociedade. Ela afirma que quer que seu filho seja feliz, seja estudando ou fazendo qualquer outra coisa que ele goste.

\section{Estudo de caso Ivan}

Trata-se de um menino de três anos e onze meses, regularmente matriculado no primeiro período da Educação Infantil (salas de aula para alunos dessa faixa etária) de uma escola da Rede Federal de Ensino. Ivan é uma criança com Síndrome de Down, que nasceu em uma família constituída por pai, mãe e duas irmãs mais velhas (sem deficiência). A gestação foi tranquila, embora logo ao nascimento tenham sido identificadas questões ligadas a saúde da criança. Ivan teve um problema cardíaco nos primeiros meses de vida, tendo sido submetido a uma cirurgia de correção de válvula esquerda. Essa cirurgia demandou cuidados específicos, exigindo que a mãe ficasse tempo integral com a criança. Aos três anos de idade Ivan foi liberado para frequentar espaços escolares.

Ao longo do acompanhamento do desenvolvimento físico da criança, aproximadamente aos treze meses de vida, foram identificados atrasos específicos: controle da espinha dorsal, aquisição de equilíbrio, coordenação motora e etc. Mais tarde, ao $32^{\circ}$ mês de vida, também foi identificado atraso no desenvolvimento da fala. Atualmente, a criança ainda se encontra em acompanhamento com uma equipe multidisciplinar de um hospital público do Estado de São Paulo (onde foram realizadas todas as cirurgias a que a criança foi submetida até hoje). O acompanhamento é focado principalmente no desenvolvimento neurológico da criança e são realizadas periodicamente testagens padronizadas para monitorar os aspectos cognitivos.

A família informa que Ivan sempre foi uma criança ativa, que gosta de estar na presença de outras crianças e que ele tem contato com diferentes membros da família. Atualmente, ele participa de diferentes espaços para auxiliar na promoção de seu desenvolvimento, tais como natação, fonoaudiologia e terapia ocupacional. A mãe narra que, quando ficou sabendo do diagnóstico do filho, ficou bastante assustada, mas que não demorou muito para que enxergasse o quanto a criança era importante para ela.

Segundo a mãe, Ivan teve um avanço grande em relação a compreensão de regras sociais. A mãe afirma que ela tinha muitas dificuldades com o comportamento de Ivan em ambientes públicos, pois frequentemente ele fugia correndo ou se jogava no chão quando ela tentava segurá-lo no colo. A mãe também conta que Ivan gosta de estar entre outras crianças, mas que nem sempre sabe como se relacionar com elas, havendo alguns casos de reclamações de mordidas ou mesmo de manifestações de gestos agressivos (tapas e arremesso de objetos) em outras crianças. A maior preocupação da família é que Ivan gosta muito do contato físico, mas ainda não sabe o que machuca e o que não 
machuca o outro; e, às vezes, não mede seus gestos. Ao mesmo tempo, a mãe demostrou estar bastante segura dos avanços de Ivan e usa a expressão, ‘está bem mais calmo’ atualmente.

A comunicação com Ivan ainda é um desafio para a família. A mãe afirma que Ivan entende tudo o que é falado com ele, embora nem sempre obedeça às orientações, mas a criança não verbaliza autonomamente o que deseja, expressando-se apenas com palavras singulares, expressões faciais e gestos indicativos (i.e., apontar para algo).

\section{Estudo de caso Amanda}

Trata-se de uma menina de três anos e dois meses, matriculada no maternal três. Nasceu em uma família constituída pela mãe, pai e irmã mais velha (quinze anos, proveniente de um casamento anterior). A gestação foi gemelar, mas houve somente o nascimento de Amanda (o outro bebê morreu na oitava semana de gestação). O diagnóstico da Síndrome de Down ocorreu apenas após o nascimento de Amanda, a família não sabendo nada sobre a Síndrome durante a gestação. Foi uma surpresa bastante grande para a família e a mãe relata que demorou alguns dias para sair de casa com o bebê. Ela não sabia o que deveria fazer e quais eram as características da Síndrome de Down.

Em relação à saúde da criança, durante os primeiros meses de vida, a mãe identificou que Amanda não ganhava peso e percebia que tinha alguma coisa "errada" com a filha. Nesses primeiros meses nenhum médico havia indicado a necessidade de realização de exames cardíacos e afirmavam que a criança estava saudável. Aos quatro meses de vida, ela foi internada com pneumonia. Somente aí é que foi descoberta uma condição cardíaca grave (Defeito de Septo Atrioventricular Total). Além de todos os problemas cardíacos, descobriu-se que ela tinha alergia a determinados tipos de alimentos (glúten, ovos, por exemplo).

Antes do primeiro ano de vida Amanda não se sentava, pesava cerca de quatro quilos e tinha muita dificuldade de comunicação, com qualquer dos outros membros da família. A mãe entende que a criança começou a se desenvolver somente a partir de um ano de vida. Ela justifica isso pelo fato de que, antes disso a vida da criança foi passada no hospital.

O primeiro contato fora do círculo familiar foi com a Instituição APAE da cidade. A busca foi para a família ter orientação sobre o que fazer com a criança com aquela síndrome. Nesta instituição, até 2015, a criança realizava atendimentos especializados como fisioterapia e fonoaudiologia. Atualmente, não está fazendo nenhum tipo de acompanhamento dessa natureza em decorrência de falta de recursos financeiros da família. Além de frequentar a APAE, Amanda passou a frequentar a escola regular (Rede Municipal), desde seus dois anos de idade.

A mãe refere que a criança é bastante extrovertida, gosta de fazer palhaçadas e interage com outras crianças quando possível, de forma bastante natural. A comunicação é feita basicamente por 
gestos, mesmo com os membros da família, que incentiva a sua comunicação do jeito que for possível ser. Amanda ainda não verbaliza palavras, mas se expressa através de gestos, sílabas e expressões faciais/corporais. A mãe afirma que ela entende tudo o que lhe é falado; o que ela não consegue é falar.

A família tem uma rede de contato com parentes, tanto adultos quanto crianças. Na percepção da mãe, Amanda interage rapidamente com outras crianças, sendo uma criança ativa e que gosta de tomar a frente das situações de brincadeira. Para a mãe, a criança é bastante esperta e não acarreta nenhum problema com a família. A mãe ressalta, em vários momentos, que a criança é bastante inteligente e que age de forma independente.

O contato de Amanda com a irmã mais velha é narrado pela mãe como bastante próximo, em uma interação de cuidado por parte da irmã mais velha (quinze anos). A mãe enfatiza que os cuidados realizados por ela com a Amanda têm sido semelhantes aos que ela realizou com a filha mais velha. Conta que a adenoide de Amanda a atrapalha bastante, principalmente na hora de dormir, fazendo com que a criança tenha noites de sono bastante agitadas, acordando muitas vezes ao longo da noite, com dificuldade para respirar.

Amanda gosta de brincar com diferentes objetos, apesar de, normalmente, perder o rápido interesse pelos brinquedos. Gosta muito de ver filmes e de estar com as pessoas da casa.

\subsection{Entrevista com professores: aspectos pedagógicos e as percepções docentes sobre a participação da criança na composição do espaço escolar}

\section{Estudo de caso Inácio}

A Instituição Escolar à qual Inácio pertence configura-se como uma Escola de Educação Básica ligada à Rede Federal de Ensino Público. Está localizada em uma cidade de médio porte do interior do Estado de Minas Gerais, dentro de um dos campi de uma das Instituições de Ensino Superior da cidade, ocupando um total de mais de três mil metros quadrados de área construída em um bloco de três pavimentos de construção. Esta Instituição recebe alunos da Educação Infantil, Ensino Fundamental Séries Iniciais $\left(1^{\circ}\right.$. ao $5^{\circ}$. ano), Ensino Fundamental Séries Finais $\left(6^{\circ}\right.$. ao $9^{\circ}$. ano) e Educação de Jovens e Adultos; é, ainda, uma Unidade Especial de Ensino dentro de uma Instituição de Ensino Superior, funcionando como um Colégio de Aplicação ${ }^{25}$.

No ano de 2014, essa escola atendeu um total de 922 alunos, sendo que desses, 22 alunos têm necessidades educacionais especiais, em decorrência de um quadro de deficiência (intelectual, física,

\footnotetext{
${ }^{25}$ São Unidades de Educação Básica dentro da Instituição de Ensino Superior que visam oferecer campo de estágios em licenciaturas e aplicação de novas metodologias de ensino na educação básica.
} 
baixa visão, deficiências múltiplas, autismo e altas habilidades). Especificamente na educação infantil, são atendidos anualmente 150 alunos, sendo que, em 2014, nove desses eram alunos com algum tipo de deficiência. Todos os alunos frequentam aulas no turno vespertino, cumprindo quatro horas e trinta minutos diários de ensino. Para os alunos com deficiência que demandam atendimento educacional especializado, horários semanais são agendados no contra turno de aula (período matutino).

Os alunos são divididos em oito salas de aula, quatro salas (com dezoito alunos cada) do primeiro período (crianças com três anos e meio a cinco anos de idade) e quatro salas (com dezenove alunos cada) do segundo período (crianças de cinco a seis anos de idade). Cabe destacar que, em cada sala de aula, pode haver mais de uma criança com deficiência. No caso específico de Inácio, em sua sala há uma outra criança que também tem deficiência, uma menina com um quadro de Síndrome de $\mathrm{KID}^{26}$.

O prédio da escola fica localizado em um bairro centralizado, em um dos campi da Universidade e a mesma recebe alunos de todas as regiões da cidade. O sistema de acesso à escola é por sorteio público, realizado uma vez ao ano. Neste sorteio, das setenta e cinco novas vagas anuais para entrada na escola, $10 \%$ são destinadas para alunos com deficiência.

A carga horária na educação infantil respeita as determinações legais de quatro horas diárias ao longo de duzentos dias letivos. A equipe docente, para realizar o atendimento educacional de toda a escola conta com um total de oitenta e dois professores efetivos nas carreiras do Ensino Básico, Técnico e Tecnológico, com dedicação exclusiva ao ensino, pesquisa e extensão. Há, ainda, onze professores contratados (contratos temporários de seis a vinte e quatro meses) e nove técnicos administrativos. Na educação infantil, conta-se com oito professoras regentes (uma para cada sala de aula), uma professora para o Espaço do brincar $^{27}$, uma professora para o Espaço cultural ${ }^{28}$ e dois professores de educação física ${ }^{29}$.

Como já relatado anteriormente, o projeto da escola prevê ações específicas com relação à educação especial. Nesse sentido, a escola conta com dois professores com formação específica em Educação Especial que coordenam o atendimento educacional especializado e acompanham os

\footnotetext{
${ }^{26}$ Síndrome que acarreta diferentes tipos de deficiência. Na criança em específico, existem lesões epiteliais em todo o corpo, com perda auditiva total em um dos ouvidos e parcial no outro; e, a perda parcial da visão em ambos os olhos. Essa criança tem um implante coclear do lado esquerdo e fotofobia, tendo que ficar protegida quando em áreas externas.

${ }^{27}$ O Espaço do brincar constitui-se como um espaço de sala de aula diferenciado, que conta com uma brinquedoteca. Neste contexto, uma professora ministra intervenções pedagógicas específicas durante o processo do brincar. Essa professora é também responsável por avaliar e acompanhar o desenvolvimento do brincar de cada criança. Essa sala de aula conta com um projeto pedagógico especifico e faz parte do currículo da Educação Infantil nesta instituição.

${ }^{28} \mathrm{O}$ Espaço cultural constitui-se como um espaço de sala de aula também diferenciado. No período das vídeo-gravações, estavam sendo desenvolvidas com as crianças atividades de musicalização, introdução à arte visual e desenvolvimento de expressão corporal. A professora é formada em Pedagogia, mas tem também formação na área de arte. Este espaço é responsável também pelo desenvolvimento de ações culturais, tais como teatro, exposições artísticas diversas, passeio a parques ou outros espaços pertinentes. As ações previstas têm projeto pedagógico específico.

${ }^{29}$ A educação física é uma atividade semanal prevista no currículo da educação infantil e ministrada por professores da área específica de educação física.
} 
processos de escolarização dos vinte e dois casos de crianças com deficiência da escola. A educação especial dentro dessa instituição ainda conta com o apoio de cinco profissionais da área da psicologia, que oferecem suporte tanto no que tange ao acompanhamento do desenvolvimento das crianças, quanto no atendimento aos familiares e professores envolvidos com o processo de escolarização daquelas crianças.

A professora regente responsável pelo processo de escolarização da criança, referida a partir desse momento pelo codinome de Renata, tem trinta e um anos de idade, foi formada em uma das Instituições de Ensino Superior da rede privada de ensino da mesma cidade. Começou sua carreira aos dezessete anos como educadora infantil, atuando em creches e Escolas Municipais de Educação Infantil. Atualmente, agora com oito anos de magistério junto à educação infantil, Renata é funcionária pública efetiva daquela instituição.

Renata afirma que, ao longo de sua trajetória docente, ela se especializou em educação especial e adquiriu experiência no atendimento educacional de crianças com deficiência, nos últimos cinco anos, durante sua atuação na Prefeitura daquela cidade. Renata menciona ter tido experiência prévia com crianças com autismo e com déficit intelectual. Ela também atuou, enquanto contratada da Prefeitura, atuando em vinte e cinco escolas, auxiliando na formação em educação especial, de professores da educação infantil.

Ela não reconhece problemas na atuação junto ao aluno com déficit intelectual e afirma que "é um desafio como qualquer outro". Reconhece que a experiência profissional anterior e a sua formação na área fazem a diferença para ela se sentir tranquila nessa atuação.

O déficit intelectual, para essa professora, é caracterizado por dificuldades do funcionamento intelectual em diversas áreas, de modo a que a criança pode vir a ter dificuldades no funcionamento cognitivo, nas atividades de vida prática e do cotidiano.

Quando questionada sobre o diagnóstico de Inácio, Renata afirma reconhecer características descritas por ela como referentes a um quadro de déficit intelectual, destacando como forma de exemplificação sua limitação, principalmente na verbalização e na comunicação de seu pensamento.

\section{Estudo de caso Ivan}

Essa criança pivô pertence à mesma Instituição de Ensino da criança anterior - Inácio. Dessa forma, as estruturas: administrativa, pedagógica e física são as mesmas. O que faz singular este caso são as características da sala de aula em que a criança está inserida. Esta é uma sala que conta com outras dezoito crianças, dentre elas um menino diagnosticado com mielomeningocele e que apresenta tanto limitações físicas (paraplegia e perda dos movimentos dos membros superiores), quanto um déficit intelectual. 
As aulas estão sobre a responsabilidade da professora Fernanda. Esta, embora não tenha uma formação específica em educação especial, tem vinte anos de experiência como professora na educação infantil, sendo dez anos atuando com base na metodologia construtivista e com alunos com déficit intelectual. A professora relata forte desejo em exercer um trabalho junto a crianças com necessidades educacionais especiais.

$\mathrm{Na}$ opinião da professora, a formação específica é fundamental e deve ser continua. Ela também afirma que, na prática, as singularidades de cada criança demandam um olhar individualizado que leve em consideração não o déficit em si, mas a criança com a qual você está trabalhando. Fernanda defende que é necessário conhecer o funcionamento de cada criança e que só a partir daí é possível estabelecer um plano de trabalho para ela.

A professora entende que o déficit intelectual significa uma condição que coloca a criança em um processo de desenvolvimento mais lento, uma vez que falta algo para ela em comparação com as crianças sem o déficit. Quando indagada se ela reconhece características de deficiência em Ivan, Fernanda pontua que esteve com a criança apenas por uma semana (a entrevista foi realizada no início do ano letivo) e que ainda o está conhecendo. Porém, ela afirma que identifica que Ivan tem uma dificuldade em se concentrar, de interagir com as demais crianças (por exemplo, para chamar as outras crianças para brincar, ele não verbaliza) e precisa de alguém o tempo inteiro com ele para ajudá-lo a entender as regras e saber se comportar em sala de aula (para não sair correndo, por exemplo).

Com relação ao planejamento pedagógico, Fernanda entende que a sistematização do trabalho se dá por meio de um planejamento para todas as crianças, com estratégias que incluam Ivan. Nesse sentido, ela diz que a presença de um outro adulto é fundamental naquele ambiente, para que isso seja efetivado. Esse outro adulto é geralmente um monitor da turma que, assim como ela, também precisa conhecer essa criança e se capacitar ao longo do processo.

A professora afirma que a escola tem dado muito suporte para que ela tenha condições de atender essa criança. Nesse sentido, ela relata sobre os planejamentos coletivos, o contato com a professora da educação especial e da área da psicologia e, principalmente, a possibilidade de ter um monitor na turma, fazendo com que o trabalho com o conjunto das crianças possa ser viabilizado. Caso contrário, a professora entende que não se sentiria tranquila para organizar sozinha uma estratégia pedagógica inclusiva, sobretudo pelo fato de ter outra criança com deficiência, afora as demais crianças com tantas outras demandas.

A professora ainda afirma que se preocupa com a interação de Ivan (de três anos e onze meses) com os demais colegas, pois ainda não o viu brincar com nenhuma criança. Segundo ela, Ivan ficou a maior parte do tempo, nos primeiros dias de aula, apenas com a monitora; e, quando ele brincou, ele preferiu brincar sozinho com seus brinquedos. Com relação às expectativas da professora com 
relação ao processo de escolarização e desenvolvimento do aluno, Fernanda diz ter boas expectativas para Ivan e relata entender que no processo de escolarização tem-se que perpassar tanto pelas questões de ordem interativa, como também do desenvolvimento intelectual. Ela espera que nesse ano Ivan consiga participar das atividades propostas e que ele entenda a dinâmica de estar em uma escola. Ela enfatiza que essa expectativa é geral para todos os alunos, não só para Ivan. Fernanda ressalta que a pesquisa na escola (fazendo menção a este estudo) é muito importante e que também tem expectativas de que isso traga novas perspectivas sobre como fazer um atendimento pedagógico adequado mediante as demandas de crianças como ele.

Cabe aqui destacar como o espaço escolar - que Ivan e Inácio frequentam - é constituído e apresentar as especificidades de cada um desses espaços, visto que as atividades desenvolvidas são distintas e implicam em diferentes formas de participação das crianças no ambiente escolar. A tabela 3 abaixo explicita a estrutura da Instituição escola de Ivan e Inácio.

Tabela 3 - Constituição dos espaços escolares - Estudos de caso Inácio e Ivan

\begin{tabular}{|c|c|c|c|}
\hline Espaço & Tamanho & $\begin{array}{l}\text { Descrição do trabalho pedagógico } \\
\text { realizado }\end{array}$ & $\begin{array}{l}\text { Responsável pelo } \\
\text { espaço }\end{array}$ \\
\hline Sala de aula & $30 \mathrm{~m} 2$ & $\begin{array}{l}\text { Todo o trabalho pedagógico é organizado a } \\
\text { partir dos referenciais nacionais para a } \\
\text { Educação Infantil. Trabalha-se dentro da } \\
\text { perspectiva das múltiplas linguagens como } \\
\text { referencial de trabalho e com uma } \\
\text { metodologia de projetos para o } \\
\text { desenvolvimento dos trabalhos. }\end{array}$ & $\begin{array}{l}\text { Professor regente e } \\
\text { mais uma monitora }\end{array}$ \\
\hline Espaço do brincar & $30 \mathrm{~m} 2$ & $\begin{array}{l}\text { O espaço da brinquedoteca é composto por } \\
\text { quatro diferentes núcleos: fantasias (onde } \\
\text { as crianças encontram vestimentas } \\
\text { específicas de fantasia infantil), brinquedos } \\
\text { pedagógicos (blocos lógicos, quebra- } \\
\text { cabeça, jogos de raciocínio lógico e etc), } \\
\text { cenários para o faz de conta (móveis e } \\
\text { brinquedos que imitam cenários da vida } \\
\text { cotidiana) e jogos/brinquedos diversos. } \\
\text { Neste espaço, a professora acompanha o } \\
\text { processo do brincar dos alunos e intervêm } \\
\text { no sentido de estimular a criatividade }\end{array}$ & $\begin{array}{l}\text { Professora (pedagoga) } \\
\text { específica com } \\
\text { formação em ateliê }\end{array}$ \\
\hline Espaço Cultural & $30 \mathrm{~m} 2$ & $\begin{array}{l}\text { Espaço para o desenvolvimento de } \\
\text { linguagens artísticas, funciona a partir de } \\
\text { um plano curricular próprio, formulado em } \\
\text { parceria com os demais professores } \\
\text { regentes e a partir dos projetos de sala que } \\
\text { serão desenvolvidos anualmente. }\end{array}$ & $\begin{array}{c}\text { Professora (pedagoga) } \\
\text { com formação em } \\
\text { ateliê ou formação em } \\
\text { arte }\end{array}$ \\
\hline Educação Física & $60 \mathrm{~m} 2$ & $\begin{array}{l}\text { Com projeto pedagógico próprio, na aula de } \\
\text { educação física, conteúdos específicos } \\
\text { dessa área de } \\
\text { (desenvolvimento }\end{array}$ do $\begin{array}{r}\text { conhecimento } \\
\text { equilíbrio, }\end{array}$ & $\begin{array}{l}\text { Professor da área de } \\
\text { educação física } \\
\text { (formação específica } \\
\text { em Ed. Física) }\end{array}$ \\
\hline
\end{tabular}


coordenação motora, dentre outros) são desenvolvidos com os alunos.

Atividade livre das crianças com a possibilidade de exploração dos brinquedos Playground $\quad 130 \mathrm{~m} 2$ do parque (parque de areia e parque de grama sintética)

No horário do lanche, as professoras são responsáveis pelo atendimento aos alunos e, portanto, acompanham tanto a Refeitório $\quad 110 \mathrm{~m} 2$ alimentação quanto o momento de lazer das crianças. As atividades são usualmente livres, raras exceções, programa-se alguma intervenção para o horário de recreio.
Professor regente com carga horaria diária de até 30 minutos.

Professor regente, ou o professor responsável pela aula anterior ao lanche.

NOTA: Por fazerem parte da mesma Instituição, essa tabela refere-se a informações dos espaços escolares para os casos Inácio e Ivan. Ainda, esclarece aqui que a monitora se trata de um aluno de graduação que cumpre uma carga horária de estágio remunerado dentro da Instituição e que sua principal atribuição é auxiliar o professor regente e desenvolver trabalhos pedagógicos dentro do seu plano de estágio.

\section{Estudo de caso Amanda}

A instituição II pertence à Rede Municipal de Ensino Público e está localizada em uma cidade de médio porte do interior do Estado de Minas Gerais. Recebe alunos apenas da Educação Infantil. Essa instituição foi considerada como uma unidade de referência na cidade, quando criada, por ter sido pensada especificamente como uma escola de Educação Infantil, com instalações consideradas pioneiras (salas com ampla vista e acesso a jardim, instalações sanitárias feitas sob medida para as crianças, espaços amplos e acessíveis, por exemplo). A escola ainda é considerada como uma referência embora haja, por parte dos professores e diretora, o reconhecimento de que as instalações necessitem de reformas e melhorias que possibilitem implementar outras práticas pedagógicas que há vinte anos atrás não estavam previstas quando da construção da escola.

Essa escola atendeu em 2014 um total de 990 alunos, sendo que vinte e nove desses alunos tinham necessidades educacionais especiais, com um quadro de deficiência. Os alunos têm de seis meses a seis anos de idade e são atendidos tanto no turno matutino quanto vespertino. Os alunos são divididos em salas de berçário (bebês de seis meses a dois anos), maternal (crianças de dois anos a quatro anos), primeiro período (crianças de quatro a cinco anos) e segundo período (crianças de cinco a seis anos). Para realizar o atendimento educacional, a escola conta com um total de 130 profissionais, dentre eles: professores, educadores ${ }^{30}$ (apoio de sala) e técnicos. Para cada sala da educação infantil, conta-se com uma professora regente, um educador, uma professora de arte e um professor de educação física.

\footnotetext{
${ }^{30}$ Funcionárias concursadas pela prefeitura, pertencentes ao quadro permanente de funcionários da escola. O referido cargo público não exigia, na data do concurso, nenhuma qualificação específica na área da educação.
} 
O prédio da escola fica localizado em um bairro periférico da cidade e atende especificamente crianças de regiões próximas a ela. $\mathrm{O}$ sistema de acesso à escola é por lista de cadastro público. A carga horária na educação infantil respeita as determinações legais de quatro horas diárias ao longo de duzentos dias letivos. Matriculada nesta instituição encontra-se a criança do estudo de caso "Amanda" (de três anos e dois meses).

No contexto da escola, Amanda está frequentando uma sala de aula que conta com a presença de uma professora regente formada em pedagogia com experiências anteriores no atendimento a crianças com deficiência. Além dela, há duas educadoras. Nesta sala, estudam mais 26 crianças, dentre elas outra criança com deficiência cuja informações específicas não foram acessíveis.

A professora de Amanda, neste trabalho denominada Angélica, tinha vinte e seis anos no momento da coleta de dados. Sua experiência profissional foi majoritariamente na rede pública de ensino municipal e sua formação inicial em pedagogia em Instituição de Ensino Superior da Rede Privada do mesmo município. Angélica tem uma formação em educação especial de 180 horas e uma experiência anterior com a educação de crianças com deficiência. O trabalho pedagógico é desenvolvido primordialmente em cinco ambientes da escola, conforme tabela 4 abaixo:

Tabela 4 - Constituição dos espaços escolares - Caso Amanda

\begin{tabular}{|c|c|c|c|}
\hline Espaço & Tamanho & $\begin{array}{l}\begin{array}{l}\text { Descrição } \\
\text { realizado }\end{array} \\
\text { do trabalho }\end{array}$ & $\begin{array}{l}\text { Responsável } \\
\text { espaço }\end{array}$ \\
\hline Sala de aula & $35 \mathrm{~m} 2$ & $\begin{array}{l}\text { Todo o trabalho pedagógico é organizado a } \\
\text { partir dos referenciais nacionais para a } \\
\text { Educação Infantil. A professora regente } \\
\text { organiza os processos de aprendizagem } \\
\text { com base nas orientações pedagógicas da } \\
\text { equipe de supervisores da escola. A sala de } \\
\text { aula é o espaço central para o } \\
\text { desenvolvimento de todas as atividades } \\
\text { com as crianças. Não possui mesas e os } \\
\text { materiais ficam guardados em armários } \\
\text { localizados em um dos lados do cômodo. }\end{array}$ & $\begin{array}{l}\text { Professor regente e } \\
\text { duas educadoras }\end{array}$ \\
\hline Sala de vídeo & $20 \mathrm{~m} 2$ & $\begin{array}{l}\text { Consiste em uma sala mobiliada com } \\
\text { almofadas e tatame. A sala é destinada } \\
\text { exclusivamente para que as crianças } \\
\text { possam assistir vídeos. }\end{array}$ & $\begin{array}{l}\text { Professora regente e } \\
\text { duas educadoras }\end{array}$ \\
\hline Educação Física & $40 \mathrm{~m} 2$ & $\begin{array}{l}\text { Aulas de educação física são ministradas no } \\
\text { pátio da escola, uma vez por semana. }\end{array}$ & $\begin{array}{l}\text { Professor de educação } \\
\text { física (formação } \\
\text { específica em Ed. } \\
\text { Física) }\end{array}$ \\
\hline Playground $\backslash$ Pátio & $300 \mathrm{~m} 2$ & $\begin{array}{l}\text { Atividade livre das crianças com a } \\
\text { possibilidade de exploração das áreas } \\
\text { externas (áreas com areia e alguns } \\
\text { brinquedos) }\end{array}$ & $\begin{array}{l}\text { Professor regente e } \\
\text { duas educadoras }\end{array}$ \\
\hline Refeitório & $110 \mathrm{~m} 2$ & $\begin{array}{l}\text { No horário do lanche, as professoras são } \\
\text { responsáveis pelo atendimento aos alunos }\end{array}$ & $\begin{array}{l}\text { Professor regente e } \\
\text { duas educadoras }\end{array}$ \\
\hline
\end{tabular}


e, portanto, acompanham a alimentação das

crianças.

NOTA: Educadores são profissionais sem formação superior específicas que auxiliam o professor regente em sala de aula junto ao grupo de alunos.

Com essas informações apresentamos as crianças, as instituições e os professores envolvidos em cada caso. Este é o cenário e parte constitutiva do processo de desenvolvimento de cada uma das crianças pivô deste estudo. Adiante seguimos com a apresentação dos resultados provenientes das análises dos vídeo-registros.

\subsection{Vídeo-registros e notas do diário de campo: Interações em análise, o mapeamento e a microgenética}

Conforme já mencionado anteriormente na metodologia, para alcançar os objetivos do trabalho foram realizados diferentes procedimentos no processo de análise dos dados. Cada procedimento foi tratado como uma 'fase' de análise (fase I, II e III) e, em cada fase, um enfoque diferente foi dado aos dados, entendendo que os mesmos pudessem vir a dar visibilidade a aspectos distintos do fenômeno.

$\mathrm{Na}$ fase I a análise focalizou na identificação e quantificação dos contatos físicos, mapeando os processos de interação dos pares ao longo do ano. Na fase II o enfoque recaiu no mapeamento das regulações de comportamento, envolvendo ou não contatos físicos e com ou sem o compartilhamento de objetos ou estabelecimento da atenção conjunta. Através desses mapeamentos, foram realizadas análises microgenéticas, buscando se entender como as interações de pares se configuram, quais e como as aprendizagens são possivelmente oportunizadas pelas interações e se nessa interação de pares encontram-se evidencias que sustentaria a hipótese da criação de ZDP nessas interações.

A partir das análises das fases I e II, retornou-se aos dados na fase III, agora visando identificar processos de aprendizagem através das corregulações de comportamento e a busca por indícios que permitissem a reflexão sobre a ZDP na relação de pares ao longo do tempo. Abaixo os resultados de cada fase, apresentado a partir da realidade singular dos três estudos de caso.

\subsubsection{Resultados da fase I - Mapeamento do contato corporal}

A fase I de análise consistiu na identificação e mapeamento das interações de pares, tendo como critério a ocorrência do contato físico entre a criança pivô e as demais crianças na sala de aula. Os resultados abrem espaço para a discussão da relação entre o espaçolatividade e a incidência de interações e o papel do contato físico na interação de pares, e serão apresentados separadamente respeitando a singularidade contida nos estudos de caso. A apresentação dos casos não segue uma única ou padronizada apresentação, cabendo aqui enfatizar-se que o objetivo não foi comparar os 
percursos de desenvolvimento dos estudos de caso, mas entender como os contatos físicos podem se configurar em função das variadas condições e contextos dos três participantes pivôs.

\section{Estudo de caso Inácio}

No caso de Inácio, as 25 semanas de vídeo registro resultaram em 755 minutos e 45 segundos de material para análise. Pela análise, identificou-se que, ao longo do ano letivo de 2014, houve 487 situações com as características de interação com contato físico. Desses 487 eventos interativos, 242 foram iniciadas por Inácio e 245 pelos demais colegas em sala. Neste caso em questão, a criança pivô foi responsável por cerca de 49,69\% das situações de interação, o que se entende ser uma diferença insignificante entre o percentual de situações interativas iniciadas pelos colegas e situações iniciadas por Inácio, conforme se pode observar na tabela 6 abaixo.

Tabela 5. - Quantitativo dos episódios de contato físico entre as crianças na fase I de análise - caso Inácio.

\begin{tabular}{ll}
\hline Situação & Análise quantitativa \\
\hline Total de situações de interação & $487-(100 \%)$ \\
Interações iniciadas por Inácio & $242-(50,31 \%)$ \\
Interações iniciadas por demais colegas & $245-(49,69 \%)$ \\
\hline
\end{tabular}

A análise das interações também revela o quantitativo de episódios de interação nos diferentes contextos da escola. Abaixo encontra-se a tabela 7, que explicita o mapeamento realizado.

Tabela 6. - Dados gerais do mapeamento de situações de interação realizado na fase I - Caso Inácio

\begin{tabular}{cccccc}
\hline $\begin{array}{l}\text { Data do } \\
\text { vídeo } \\
\text { registro }\end{array}$ & $\begin{array}{l}\text { Total de } \\
\text { minutos } \\
\text { analisados }\end{array}$ & $\begin{array}{l}\text { Interaç̃̃es } \\
\text { iniciadas por } \\
\text { Inácio }\end{array}$ & $\begin{array}{l}\text { Interações } \\
\text { iniciadas } \\
\text { por } \\
\text { colegas }\end{array}$ & $\begin{array}{l}\text { Total de } \\
\text { interações }\end{array}$ & Local \\
\hline $\mathbf{2 0 . 0 3}$ & $36^{\prime} 05^{\prime}$ & 6 & 5 & 11 & Sala de aula \\
$\mathbf{2 7 . 0 3}$ & $21^{\prime} 45^{\prime}$ & 9 & 7 & 16 & Sala de aula \\
$\mathbf{0 3 . 0 4}$ & $29^{\prime} 5^{\prime}$ & 10 & 7 & 17 & Sala de aula \\
$\mathbf{1 5 . 0 4}$ & $49^{\prime} 46^{\prime}$ & 15 & 27 & 42 & Sala de aula \\
$\mathbf{2 9 . 0 4}$ & $99^{\prime} 57^{\prime}$ & 3 & 2 & 5 & Espaço Cultural \\
$\mathbf{0 9 . 0 5}$ & $12^{\prime} 40^{\prime}$ & 1 & 0 & 1 & Musicalização \\
$\mathbf{2 1 . 0 5}$ & $39^{\prime} 44^{\prime}$ & 16 & 9 & 24 & Sala de aula \\
$\mathbf{2 8 . 0 5}$ & $42^{\prime} 30^{\prime}$ & 17 & 21 & 38 & Sala de aula \\
$\mathbf{0 4 . 0 6}$ & $12^{\prime} 1^{\prime}$ & 2 & 2 & 4 & Sala de aula \\
$\mathbf{2 9 . 0 7}$ & $27^{\prime} 03^{\prime \prime}$ & 10 & 13 & 23 & Espaço do Brincar \\
$\mathbf{0 1 . 0 8}$ & $9^{\prime} 43^{\prime}$ & 3 & 1 & 4 & Sala de aula \\
$\mathbf{0 5 . 0 8}$ & $19^{\prime} 55^{\prime}$ & 14 & 3 & 17 & Sala de aula
\end{tabular}




\begin{tabular}{|c|c|c|c|c|c|}
\hline 13.08 & $13^{\prime} 42^{\prime \prime}$ & 8 & 13 & 21 & Playground \\
\hline 21.08 & $23^{\prime} 47^{\prime \prime}$ & 11 & 9 & 20 & Sala de aula \\
\hline 04.09 & $50 ’ 10 "$ & 14 & 9 & 23 & Educação física \\
\hline 08.09 & $33^{\prime} 49^{\prime \prime}$ & 14 & 4 & 18 & Sala de aula \\
\hline 15.09 & $43^{\prime} 09^{\prime}$ & 13 & 14 & 27 & Espaço do brincar \\
\hline 22.09 & $50 ’ 40^{\prime}$ & 15 & 18 & 43 & $\begin{array}{c}\text { Sala de aula e Espaço } \\
\text { Cultural }\end{array}$ \\
\hline 25.09 & $39^{\prime} 53^{\prime \prime}$ & 4 & 6 & 10 & $\begin{array}{l}\text { Sala de aula com } \\
\text { intervenção da psicologia }\end{array}$ \\
\hline 29.09 & $35^{\prime} 52^{\prime \prime}$ & 7 & 4 & 11 & Sala de aula \\
\hline 06.10 & $42^{\prime} 10^{\prime \prime}$ & 15 & 13 & 28 & Sala de aula e refeitório \\
\hline 29.10 & $47^{\prime} 29{ }^{\prime \prime}$ & 9 & 6 & 15 & $\begin{array}{c}\text { Sala de aula com a educação } \\
\text { especial }\end{array}$ \\
\hline 04.11 & $36^{\prime} 05^{\prime \prime}$ & 11 & 19 & 30 & Playground \\
\hline 26.11 & $28^{\prime} 00^{\prime \prime}$ & 8 & 6 & 14 & Sala de aula \\
\hline 03.12 & $30 ’ 01{ }^{\prime \prime}$ & 7 & 18 & 25 & Playground e sala de aula \\
\hline
\end{tabular}

Os resultados indicam que, nessa escola e para essa criança, a quantidade de iniciativas dos contatos físicos se diferencia em relação aos diferentes espaços organizados pela escola. Em contexto de sala de aula, majoritariamente, os contatos físicos ocorrem com maior frequência a partir de Inácio. No entanto, o inverso se dá em momentosłcontextos fora da sala como, por exemplo, no playground, onde a diferença entre o número de interações iniciadas pelas crianças e as iniciadas por Inácio, é maior.

Reconhece-se, neste trabalho, o espaço como um elemento circunscritor importante na análise das possibilidades de ocorrência (ou não; maior ou menor frequência) da interação. Nesse sentido, vale considerar que o espaço é constituído por diferentes dimensões, as quais estão intrinsicamente ligadas às atividades humanas, crenças, valores, regras e ideologia cultural (Soja 1996). Estudos que analisam a composição do espaço institucional adotando uma perspectiva sociológica de escuta às vozes das crianças nos processos investigativos, (Schmidt, 2011; Raittila, 2012; Rutanen, 2014; Vuorisalo, Rutanen \& Raittila, 2015) revelam que as crianças constroem sentidos para esses espaços que muitas vezes rompem com o que seria idealizado, trazendo novos significados para esse contexto. Segundo Vuorisalo, Rutanen e Raittila (2015), na organização dos espaços institucionais estão contidos elementos que permitem (ou não) determinadas formas de experiência (i.e., o planejamento do ambiente, os equipamentos, os ritmos definidos, as regras sociais, entre outros, definem uma forma específica de apropriaçãoluso desse espaço) para a criança, possibilitando (ou não) sua participação na tomada de decisões que envolvem o fazer na rotina institucional.

Investigando em detalhe esses dois espaços (sala de aula e playground) e tendo como referência a organização do espaço físico, a natureza das atividades desenvolvidas e os materiais 
utilizados, observa-se que: no contexto de sala de aula de Inácio, a disposição dos móveis nos $35 \mathrm{~m}^{2}$ da sala é organizada diariamente de acordo com a atividade proposta, essa podendo acontecer no chão (e.g., momentos de roda, de conversa com o grupo, ou de atividades que envolvem os brinquedos) ou em mesas (total de cinco), que acomodam até quatro crianças. Na sala de aula, são priorizadas atividades orientadas (com supervisão direta do professor ou monitor), em que instruções sobre o que fazer são dadas para as crianças e onde a mediação de um adulto faz parte do processo da atividade. As atividades desenvolvidas nesse contexto podem ser individuais (quando um aluno tem seus próprios materiais e sua atividade específica) ou em grupo (quando os materiais são compartilhados e a atividade é única para todos os alunos). Nesse contexto, Inácio pode contar com o apoio de uma monitora que, de tempos em tempos, está próxima para auxiliá-lo. Os materiais utilizados regularmente ficam estocados em um armário que toma toda a parede lateral direita da sala (do chão ao teto) e, sob a supervisão da professora, são distribuídos às crianças quando necessário. Na lateral esquerda da sala, onde se localizam as janelas, encontram-se duas estantes com uma ampla variedade de brinquedos, uma estante com livros infantis, um tapete de EVA (dois metros quadrados) e a mesa da professora.

A partir das análises feitas, identifica-se que o espaço físico da sala de aula é significativamente menor que o do playground, o ritmo das atividades e a quantidade de estímulos são supervisionados pela professora e sua(s) monitora(s) e que a quantidade de móveis, bem como a sua distribuição, proporciona que as crianças estejam mais próximas umas das outras, em constantes situações de negociação, o que possivelmente justificaria a ocorrência de maior número no total de contatos físicos. Contudo, não foi identificada nenhuma relação direta entre o tipo de atividade desenvolvida na sala de aula e a incidência de contatos físicos; ou seja, não houve uma atividade específica em que fosse identificado um número maior de contatos físicos entre as crianças. As atividades desenvolvidas em sala de aula (com exceção do dia 25.09), não pressupunham o contato físico. Majoritariamente, eram atividades em que as crianças dividem o mesmo espaço e objetos, mas realizam ações individuais onde o contato com o parceiro não é um pré-requisito. Da mesma forma, não foi identificado nenhum elemento do espaço físico que justificasse a diferença entre o número de iniciativas de contato físico realizadas por Inácio e aquelas realizadas pelas demais crianças.

$\mathrm{Na}$ sala de aula, o contato envolvendo Inácio está presente em diversos momentos, propiciando e constituindo diferentes tipos de ações, tais como: quando ele inicia uma brincadeira (figura 2.); participal constrói uma brincadeira com o colega (figura 3.); toca aleatoriamente o colega (figura 4.); pega algo de outro colega (figura 5.); demonstra carinho (figura 6.). Os colegas também buscam contato com Inácio: chamando-o para participar de atividades (figura 7.); tentando pegar 
objetos das mãos de Inácio (figura 8.); ou mesmo limitando seu acesso aos materiais (figura 9.). Abaixo, as imagens que ilustram os momentos descritos acima.

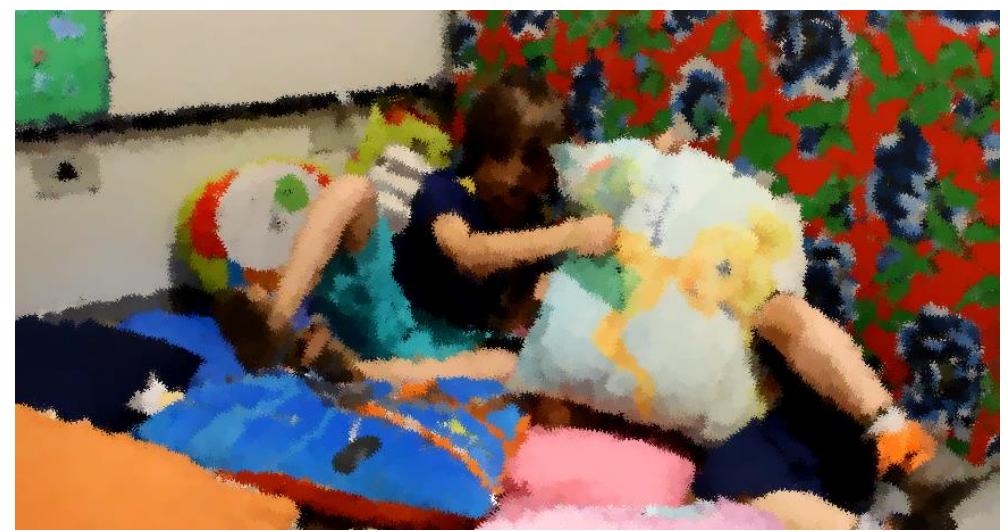

Figura 2. Inácio segura o colega e joga uma almofada sobre ele.

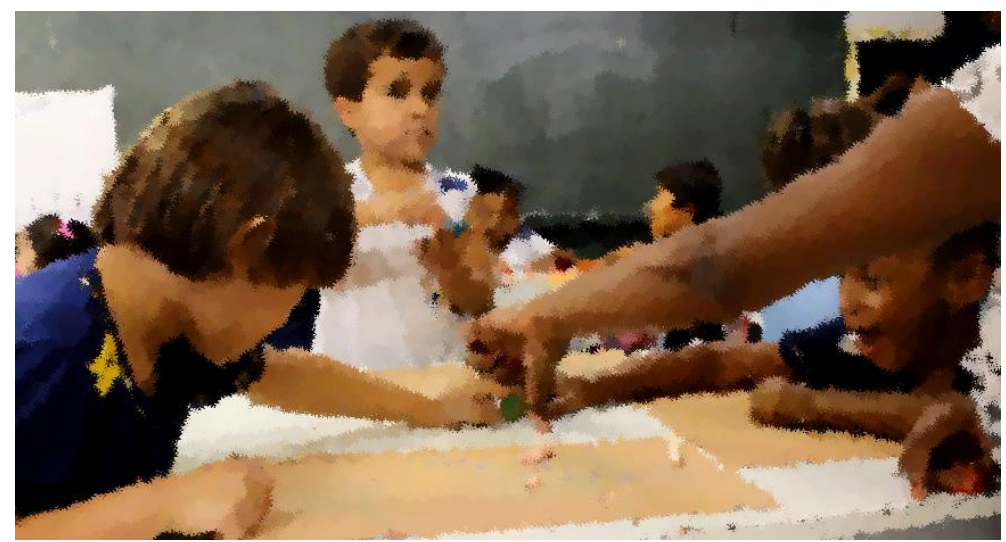

Figura 3. Inácio e Gabrielly brincando de passar a bolinha por debaixo das mãos da monitora.

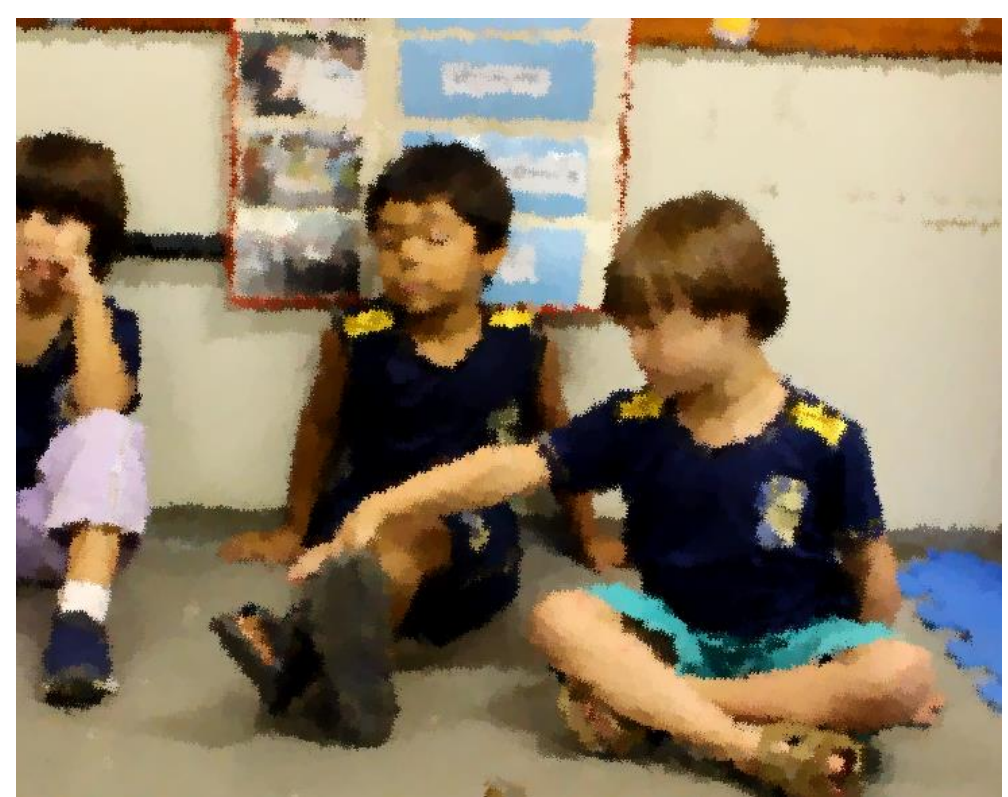

Figura 4. Inácio toca os pés do colega durante a contação de história. 


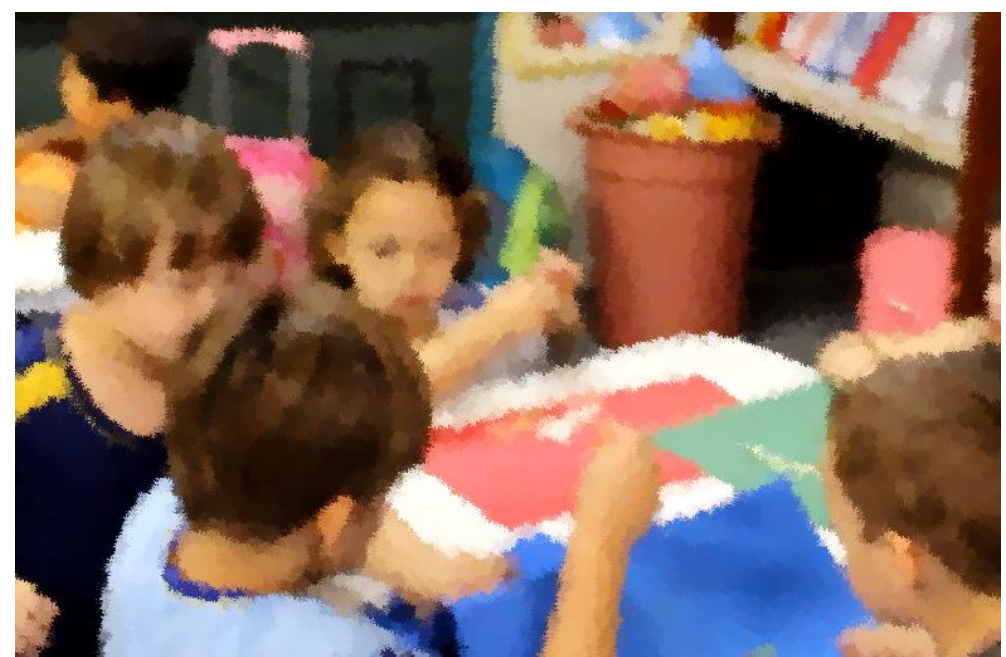

Figura 5. Inácio tenta pegar a massa de modelar das mãos do Felipe.

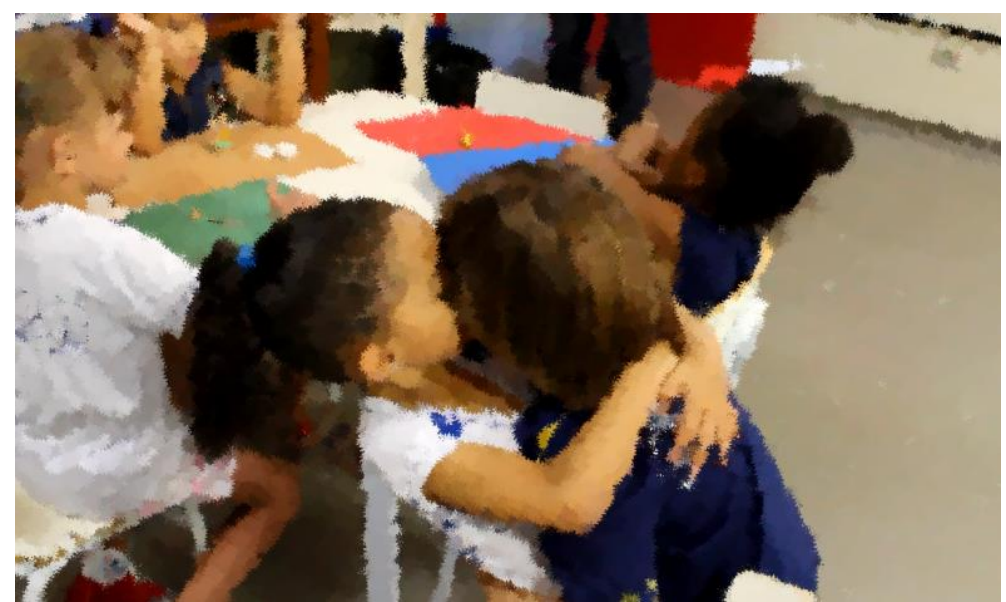

Figura 6. Lorena abraça e beija Inácio.

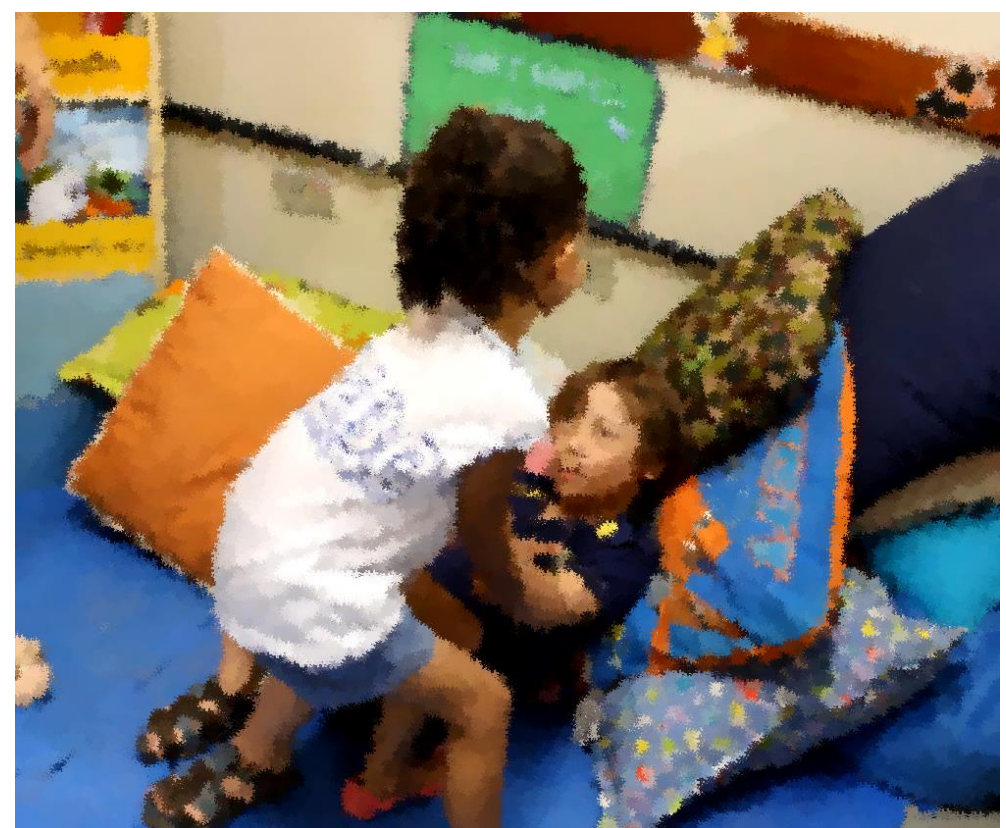

Figura 7. Lorena puxa o braço de Inácio, chamando-o para a atividade. 


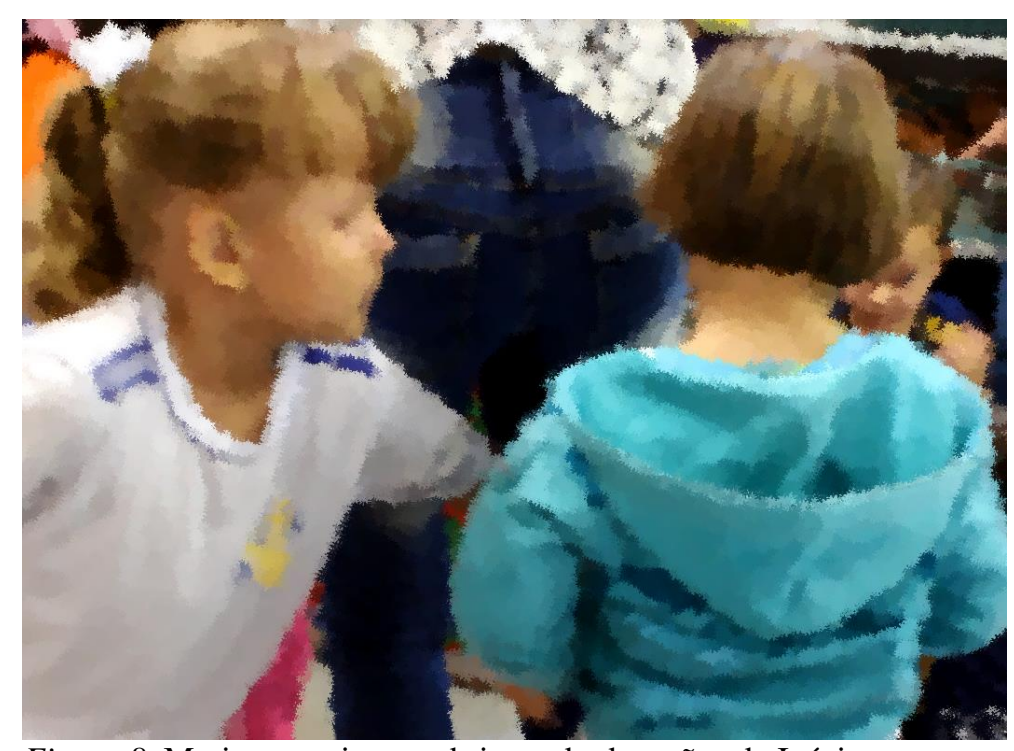

Figura 8. Maria tenta tirar um brinquedo das mãos de Inácio.

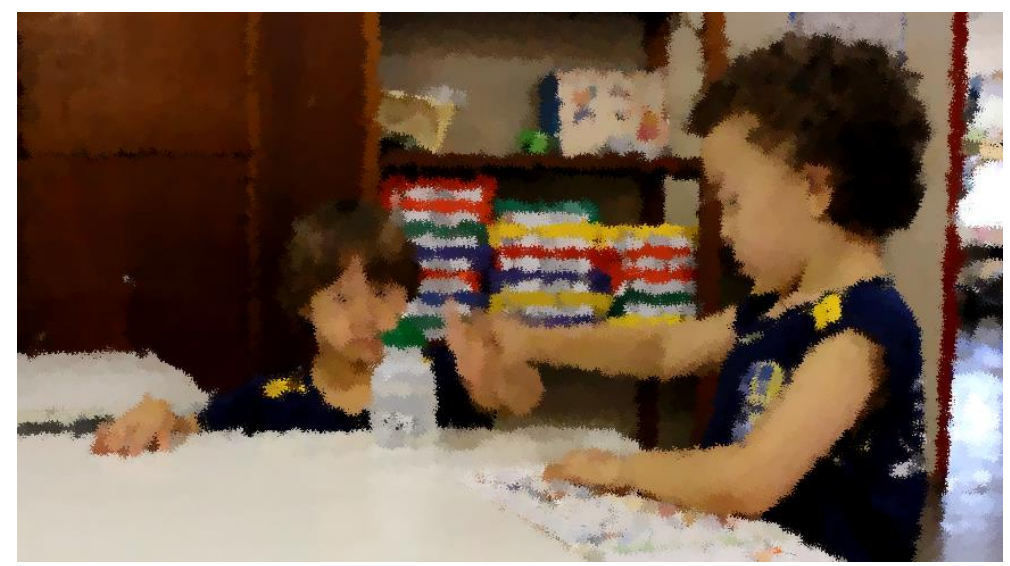

Figura 8. Breno retira o braço de Inácio do livro que ele está olhando.

Já no contexto do playground, a organização dos $300 \mathrm{~m}^{2}$ é fixa ao longo de todo ano letivo, aquele ambiente sendo dividido em quatro partes: um parquinho com areia (área coberta com areia tratada, que acomoda dois escorregadores e um trepa-trepa), a ducha (espaço aonde estão instalados canos d'agua, que quando abertos servem de ducha para as crianças brincarem com água), o pátio (espaço de cimento sem cobertura), e os brinquedos sob grama sintética (área que acomoda duas estruturas de playground de polietileno de tamanho médio, uma estrutura de tamanho pequeno e um balanço adaptado para cadeirantes).

Neste espaço, são priorizadas atividades livres (sem supervisão direta do professor ou monitor), em que as crianças são estimuladas a explorarem os recursos (e.g., brinquedos do parquinho ou materiais que as crianças levam diariamente para esse espaço) e criarem brincadeiras entre si. As atividades desenvolvidas nesse contexto são, majoritariamente, coletivas e neste contexto Inácio conta com menos apoio da monitora que de forma usual acaba por mediar apenas situações de 
conflitos. Os materiais utilizados são os brinquedos disponíveis nos espaços e/ou aqueles trazidos pelas crianças de casa ou da sala de aula.

O playground proporciona condições para as crianças circularem livremente. Como o uso desse espaço é feito também por outras turmas de alunos da educação infantil no mesmo horário, aumenta-se a possibilidade de contato com crianças de outros grupos etários e dispersam-se os grupos que regularmente trabalham juntos em uma mesma sala de aula. Os materiais (brinquedos e estruturas fixas) suscitam atividades de intenso exercício físico (e.g., escalar, escorregar, balançar, correr, pular e etc.), diferenciando significativamente do tipo de demandas da sala de aula. Contudo, analisando especificamente esse espaço, novamente não se encontra nenhuma relação direta entre o tipo de atividade e a incidência de contatos entre Inácio e outras crianças, ou seja, não houve uma atividade ou momento específico em que fosse identificado um número maior de contatos entre as crianças no playground. As atividades no playground, embora coletivas, não necessariamente demandam contatos físicos.

No playground, o contato iniciado por Inácio aparece em situações para demonstrar carinho (figura 9.), ou participarlconstruir uma brincadeira com o colega (figura 10.). Os colegas, em contrapartida, estabelecem contato em situações em que eles chamam Inácio para participar da atividade (figura 11.), ou para chamar sua atenção quando julgam que ele faz algo errado (figura 12.). Abaixo, as imagens que ilustram os momentos descritos acima.

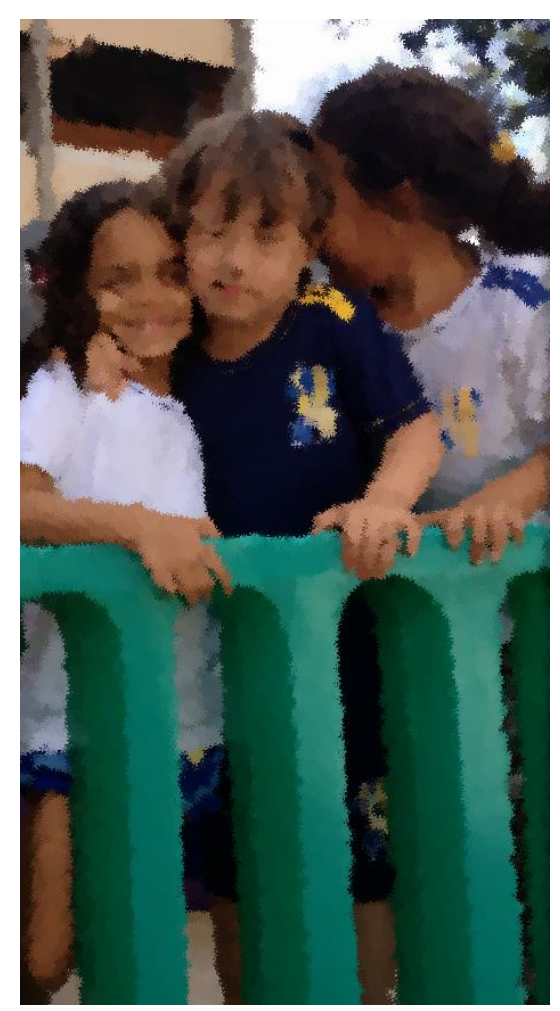

Figura 9. Inácio abraçando Lorena e Isabela. 


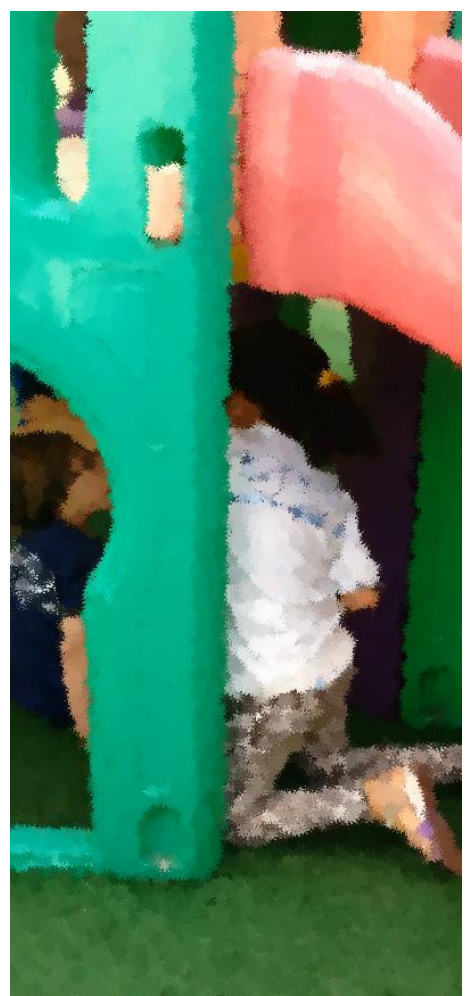

Figura 10. Inácio entrando na brincadeira com Isabela.

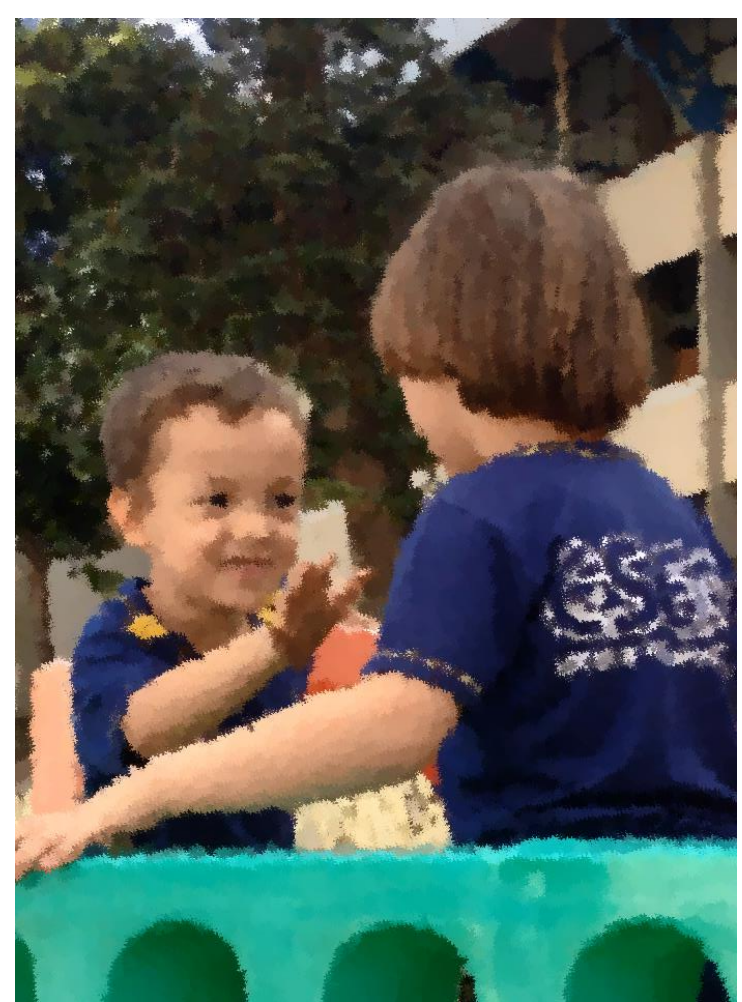

Figura 11. João Pedro chamando Inácio para brincar. 


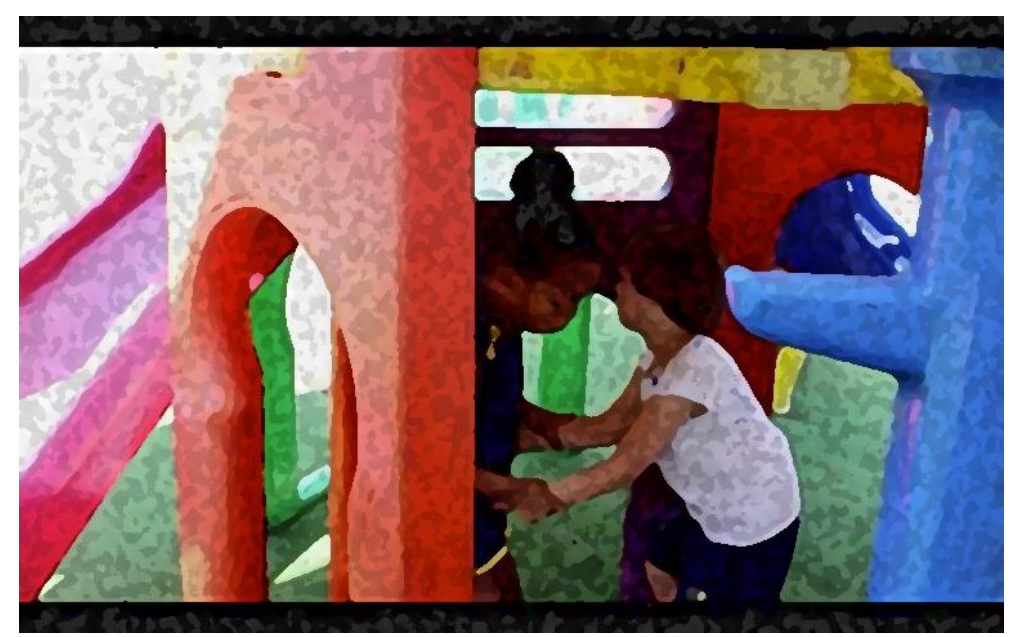

Figura 12. Maria Gabriela chamando atenção de Inácio pelo seu comportamento.

Dois elementos importantes que talvez pudessem justificar o porquê de Inácio tomar maior iniciativa de contatos físicos no ambiente de sala de aula seriam, primeiramente, o fato de que no ambiente de sala de aula a velocidade com que as ações acontecem é mais lenta do que no playground e, em segundo, que o contexto da sala de aula favorece um contato mais próximo entre os alunos, enquanto que no playground o dinamismo e a oferta de estímulos são maiores. Esses dois fatores possivelmente permitiriam, para essa criança, maior tempo para observar, planejar e atuar no contexto da sala de aula. Em contrapartida, levanta a hipótese de que no playground pode estar ocorrendo maior interação sem contato físico, mas com regulação de comportamento (elemento a ser analisado na fase II), em que Inácio vai apreendendo as brincadeiras e sendo regulado pelos colegas, mesmo sem estar junto a eles. Independentemente do local onde os contatos físicos ocorreram pela análise quantitativa geral dos contatos físicos é possível observar a constância e reciprocidade na procura pela interação de pares.

Outro dado relevante referente à relação entre a quantidade de situações de interação e o local (espaço escolar) é que os dados revelam que houve uma diferença, embora pequena (variação de no máximo 0,4 pontos) no número total de situações de interação com contato físico entre os diferentes espaços escolares no caso estudado. Na somatória de todos os contatos físicos (aqueles iniciados por Inácio e aqueles iniciados pelos pares), dividido pelo tempo de registro em cada um dos diferentes espaços da escola (sala de aula, espaço do brincar, espaço cultural e playground), a sala de aula aparece com um resultado de 0,57 'contatos físicos por minuto de registro' enquanto que no playground a relação é de 0,9 'contatos físicos por minuto'. Reconhece-se que a mensuração dos episódios de contato físico dessa forma não tem uma relação direta com a solução do problema proposto neste estudo, mas oferece parâmetros para a análise de como os espaços físicos e as atividades circunscrevem os processos de interação. Ainda, levando em consideração que os contatos físicos são formas de se estabelecer interação e que a interação com o outro é o processo pelo qual o 
desenvolvimento ocorre, corrobora-se com alguns autores na literatura sobre desenvolvimento na infância (Schmitz, 2012; Mello, 2011; Kishimoto, 2000) que destacam que as atividades lúdicas e os espaços voltados para o processo do brincar sejam prioritários para o desenvolvimento das crianças.

A forma como os contatos físicos acontecem é particular de cada caso e os sentidos da busca pelo outro serão ainda mais profundamente analisados em tópico posterior nessa tese. Porém, buscando ilustrar que no caso Inácio o contato físico aparece predominantemente em situações em que ele busca a participação no grupo, apresenta-se um episódio de interação entre Inácio e um grupo de meninas, seis meses após o ingresso na instituição. Este episódio mostra uma das sete tentativas de participação em atividades coletivas que Inácio realizou ao longo de dezenove minutos de observação daquele dia.

\section{Inácio em: "Eu também quero brincar"}

\section{Data: 05 de agosto de 2014, gravação (1) 3'21',}

Contexto geral: As crianças estão na sala de aula e a professora organizou quatro cantos da sala com atividades diferentes, dentre estas uma atividade de avaliação do reconhecimento das letras que a professora desenvolve com as crianças. As crianças se agruparam livremente nos quatro cantos e escolheram as atividades que gostariam de fazer. Nesta cena, vê-se um grupo formado exclusivamente por meninas, uma prática que estava sendo bastante comum naquele período.

Descrição da cena: Inácio aproxima-se de um grupo das meninas (Maria Gabriela, Laura, Elis e Lorena), mas elas não manifestam nenhuma reação. Inácio senta ao lado de Lorena, estende sua mão em direção ao ombro dela, a toca e balbucia algo (incompreensível). Lorena balança a cabeça em sinal de negativa e Inácio coloca as mãos entre a cabeça e olha para os objetos a sua frente. Elis reconhece sua presença e fala seu nome vagarosamente "Inácio". Maria Gabriela completa falando "você não é daqui". As meninas continuam a brincadeira enquanto Inácio olha. Inácio então se aproxima de Lorena, toca seu braço, chamando sua atenção, mas ela o ignora. Inácio se afasta, senta na cadeira localizada atrás do grupo, olha por alguns segundos e então caminha em direção ao grupo novamente. Inácio senta entre Lorena e Maria Gabriela, essa que imediatamente o repreende dizendo "não Inácio" ao mesmo tempo que estende sua mão em direção a Inácio, impedindo-o de se aproximar. Maria Gabriela tem o apoio de outra colega que fala "ah não" e então continua dizendo "ele quer pegar as pecinhas, mas eu disse que não". Inácio vira de costas para o grupo e sai. Ele se senta na cadeira olha em direção a outro grupo de crianças, levanta-se, caminha em direção ao outro grupo, olha, volta o olhar para o grupo de meninas. Inácio se aproxima novamente, abaixa-se agora apenas olhando, toca em uma peça que se encontra afastada do montante, olha para as meninas. Lorena olha para Inácio mas não fala nada. Maria Gabriela vê que Inácio pegou a peça e fala "não", tomando dele o brinquedo. Inácio levanta, olha para o grupo. As meninas continuam brincando. Inácio caminha circulando o grupo, abaixa-se e senta do lado de Lorena, um pouco mais afastado do grupo, se posicionando lateralmente em direção ao grupo de meninas e encostando sua perna nas costas da colega. Inácio pega um brinquedo que está no chão e começa a usá-lo. Ele olha para os brinquedos que as meninas estão montando, olha para Lorena, olha para o seu próprio brinquedo e permanece ali por alguns instantes. 


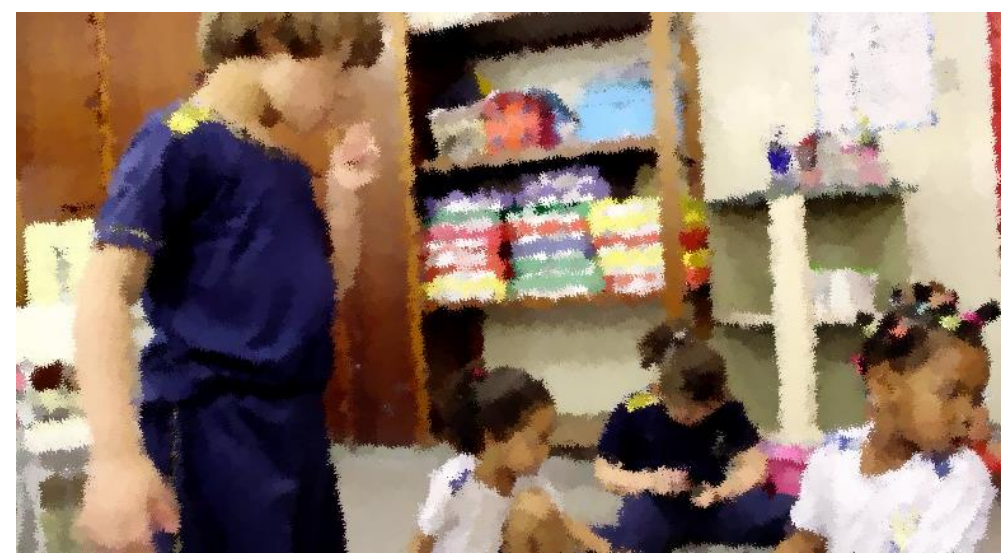

Figura 6. Aproximação de Inácio ao grupo de meninas.

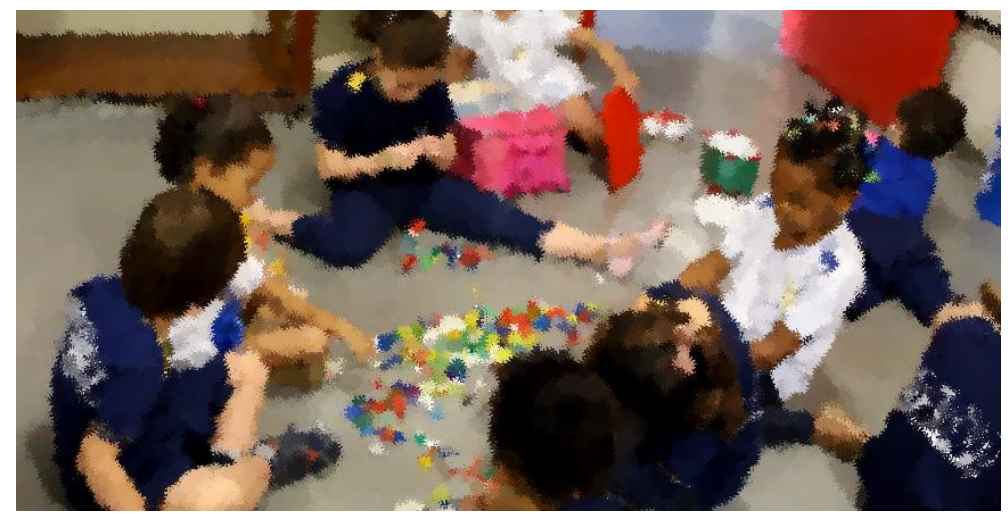

Figura 7. Inácio tocando no ombro da colega Lorena, chamando sua atenção.

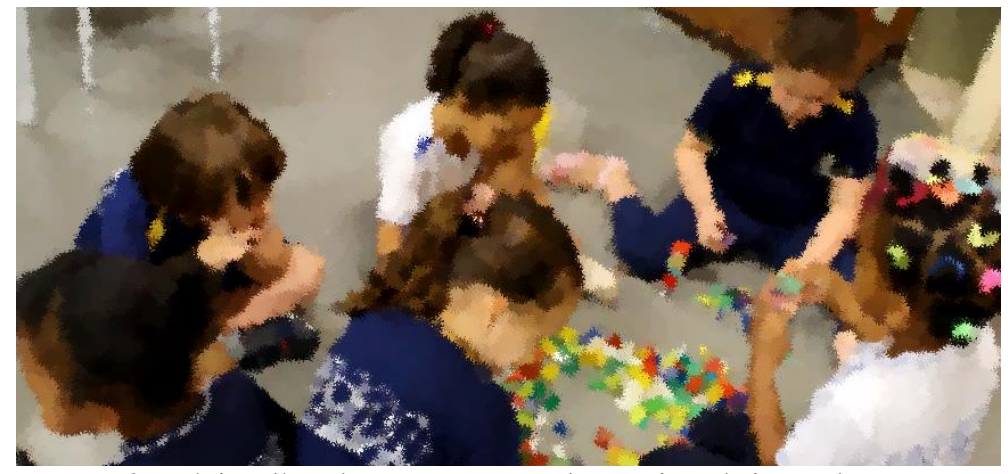

Figura 8. Inácio olhando para o grupo de meninas brincando.

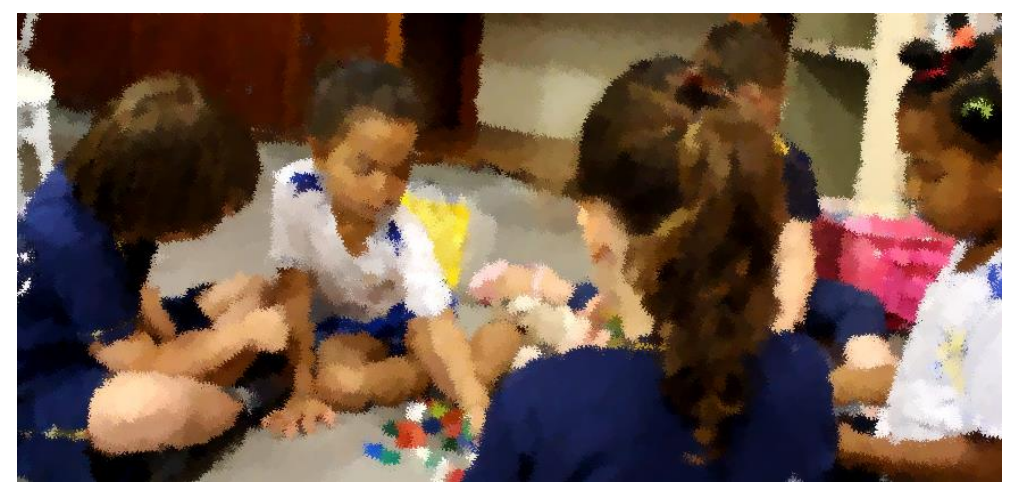

Figura 9. Inácio encostando no braço de Lorena. 


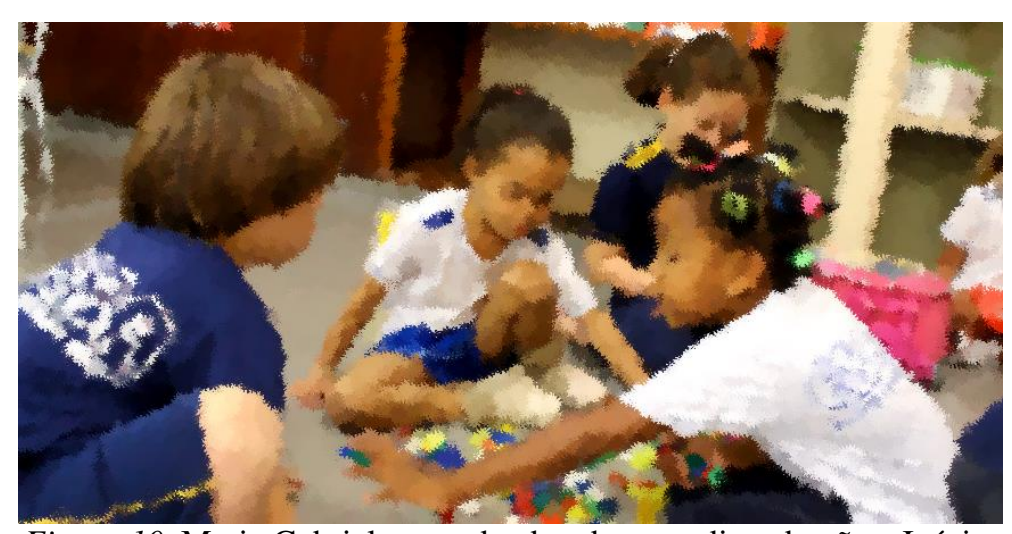

Figura 10. Maria Gabriela estendendo o braço e dizendo não a Inácio.

Ao longo do episódio, o contato físico iniciado por Inácio compõe um processo que é aqui interpretado como uma tentativa, a partir de diversos recursos (e.g., tocar o ombro, tocar o braço, olhar, esperar, sentar-se do lado da colega, tocar-lhe a mão), de fazer parte do grupo, revelando a forma como Inácio age em atividade livres em grupo na sala de aula. Cabe aqui destacar que Inácio não se aproxima aleatoriamente, ele escolhe o contato físico com Lorena que se constituiu ao longo do tempo como um par preferencial (envolvida em 71 dos 242 episódios de contato físico iniciados por Inácio, 29\%).

Por parte dos colegas, o contato físico aparece como uma forma de limitar o acesso de Inácio aos brinquedos, o que traria concretude a sua não participação na brincadeira. Maria Gabriela utilizase também de comandos verbais para repelir a ação de Inácio na iniciativa de participação, mas é o contato físico que corporalmente o mantém afastado. Apesar da materialidade da resposta negativa nos gestos de Maria Gabriela, Inácio continua, ao longo dos dezenoce minutos, buscando fazer diferentes aproximações. Em nenhuma delas, ele chama o adulto para intervir. Ao contrário, sua abordagem é feita através dos diferentes pares presentes no momento, com destaque ao par preferencial - Lorena.

$\mathrm{Na}$ literatura que trata diretamente do processo de escolarização da criança com deficiência, Odom, Brown, Schwartz, Zencher e Sandall (2002) apontam que crianças com diagnóstico de deficiência sofrem três vezes mais rejeição por parte dos pares do que crianças sem nenhum diagnóstico. Odom et. al (2002) discutem ainda que as crianças com deficiência têm experimentado o processo de escolarização por meio quase que exclusivo da mediação de adultos e que, ao longo do tempo, isso tem interferido na frequência com a qual elas procuram por outros pares. Ainda, em alguns trabalhos da área, verificou-se uma discussão que enfatiza que as crianças com déficit intelectual apresentam dificuldade na iniciativa dos processos interacionais em decorrência de uma comunicação deficitária (Feuerstein \& Lewin-Benham, 2012), ou pela sua limitação cognitiva para compreender e acompanhar as dinâmicas presentes em espaços escolares (Marques, 2001). 
Entretanto, os dados aqui obtidos revelam que esta criança com déficit intelectual procurou constantemente (várias vezes ao dia) e permanentemente (ao longo de todo o ano letivo) os seus pares de idade, mesmo que essa procura não tenha resultado na participação almejada. A assistência oferecida pela monitora da sala parece não ter influenciado na diminuição do movimento de Inácio pela procura pelos pares (não há indícios de diminuição de contatos físicos ao longo do tempo) e o fato de Inácio não verbalizar por meio dos códigos linguísticos convencionais os seus desejos e pensamentos não impediu que ele tentasse por diferentes vias a aproximação a esse grupo de meninas.

De forma geral, a literatura aponta que a inclusão de alunos com deficiência intelectual depende muito das ações do professor em sala de aula, no sentido de que seja ele o mediador de pontes entre as crianças (Feuerstein \& Lewin-Benham, 2012; Tébar, 2011). Estudos apontam que simplesmente oportunizar momentos de interação entre pares com e sem deficiência não é suficiente para que se obtenha uma interação significativa (Kamps, Kravits, Lopez, Kemmerer, Potucek \& Harrel, 1998; Kemple, 2004), indicando que o professor necessita implementar estratégias para a promoção de interações sociais eficientes (Terpstra \& Tamura, 2008). Sem desconsiderar a relevância do papel do professor na promoção da interação de pares no contexto inclusivo de educação, chamase a atenção para (1) os aspectos constituidores que também estão presentes na ausência da interferência direta e constante do adulto; e, (2) para a necessidade de se ampliar a perspectiva de análise do que sejam interações significativas elou eficientes, adotando por base o entendimento de que é por meio de todas as interações que o ser humano se constitui.

Ao se olhar para esse episódio sobre a ótica de como os comportamentos de Inácio vão sendo constituídos, se entende que os constantes contatos físicos que manifestaram as respostas negativas das crianças às tentativas de aproximação de Inácio, foram instrumentos que possibilitaram a criança pivô a mudar sua estratégia de aproximação e a considerar outras formas de contato (encostando na colega) como vias de participação. Retoma-se aqui a ideia contida nos pressupostos da Rede de Significações sobre como as contradições e as ambivalências fazem parte e singularizam o processo de desenvolvimento (Rossetti-Ferreira, Amorim \& Silva, 2004), levando em consideração que "sempre existirão percursos possíveis que não foram percorridos, havendo habilidades e capacidades que não puderam vir a ser adquiridas" (p. 30). Neste sentido, a não interferência do adulto possibilitou que a criança pivô se adaptasse às possibilidades oferecidas pelas crianças, dentro da cultura de pares em construção e que, neste caso, foram possibilidades de uma participação parcial ao momento vivido pelo grupo.

É importante destacar ainda que existem múltiplos fatores que interferem na constituição de grupo de brinquedo no contexto da educação infantil. Neste dia de registro, por exemplo, as 
informações de diário de campo revelam que a rejeição pela aproximação de Inácio não se referia necessariamente à condição da Síndrome de Down, mas sim ao gênero masculino.

Informação do diário de campo - Date 05 August o 2014

A gravação de hoje mostra muitas situações em que Inácio é persistente ao tentar fazer parte das atividades das outras crianças. Ele tentou muitas vezes iniciar uma atividade conjunta, na qual as crianças se afastam dele ou mudam para outra atividade. Eu não sei exatamente porque estava acontecendo e cheguei a me perguntar se era porque a crianças precisam de recursos comunicativos que Inácio não oferece. Mas ao longo da filmagem a professora percebeu que um grupo de garotas não queria deixar Inácio brincar com elas e veio justificar o que estava acontecendo espontaneamente. De acordo com a professora, as meninas estão começando a separar as brincadeiras de meninas e as brincadeiras de meninos e frequentemente não tem deixado os meninos brincarem com elas. Essa pode ser uma das possibilidades para se entender o processo de interação.

Como é possível observar, as situações de interação estão circunscritas em um complexo universo de elementos, muitos deles não necessariamente perpassam à própria deficiência, mas a outros aspectos do desenvolvimento infantil nesta faixa etária. Tais aspectos precisam ser incorporados na análise dos processos de interação, contextualizando-os no percurso de desenvolvimento de cada criança, de cada grupo. Por fim, é possível dizer que o contato físico é, em muitas situações, utilizado como suporte para o fazer conjunto, chamando a atenção do par para objetos ou situações e envolvendo-o em situações em que, possivelmente, significados são compartilhados, sendo essa a ponte que possibilita aprendizagens.

\section{Estudo de caso Ivan}

O processo de análise do caso Ivan aconteceu por meio dos 759 minutos de vídeo registros, ao longo do ano letivo de 2014. Nesse período, foram identificadas 337 situações de interação; dessas, 207 interações foram iniciadas por Ivan e 130 por pares. Na tabela 7 abaixo, dispõe-se das localidades onde essas interações aconteceram.

Tabela 7. - Dados gerais do mapeamento de situações de interação realizado na fase I - Caso Ivan

\begin{tabular}{cccccc}
\hline $\begin{array}{l}\text { Data do vídeo } \\
\text { registro }\end{array}$ & $\begin{array}{l}\text { Total de } \\
\text { minutos } \\
\text { analisados }\end{array}$ & $\begin{array}{l}\text { Interações } \\
\text { iniciadas por } \\
\text { Ivan }\end{array}$ & $\begin{array}{l}\text { Interações } \\
\text { iniciadas por } \\
\text { colegas }\end{array}$ & $\begin{array}{l}\text { Total de } \\
\text { interações }\end{array}$ & Local \\
\hline $\mathbf{2 0 . 0 3}$ & $20^{\prime} 02^{\prime \prime}$ & 1 & 0 & 1 & Sala de aula \\
$\mathbf{2 7 . 0 3}$ & $24^{\prime} 51^{\prime}$, & 13 & 5 & 18 & Sala de aula \\
$\mathbf{0 3 . 0 4}$ & $2^{\prime} 53^{\prime}$, & 0 & 6 & 1 & Sala de aula \\
$\mathbf{0 7 . 0 4}$ & $46^{\prime} 32^{\prime}$, & 6 & 4 & 10 & Espaço Cultural \\
$\mathbf{2 3 . 0 4}$ & $46^{\prime} 09^{\prime}$, & 7 & 2 & 9 & Educação física \\
$\mathbf{2 9 . 0 5}$ & $36^{\prime} 37^{\prime}$, & 6 & 18 & 24 & Playground
\end{tabular}




\begin{tabular}{|c|c|c|c|c|c|}
\hline 27.07 & $22^{\prime} 30^{\prime \prime}$ & 2 & 4 & 6 & Sala de aula \\
\hline 01.08 & $12^{\prime} 02^{\prime \prime}$ & 4 & 5 & 9 & Psicologia Escolar \\
\hline 21.08 & $17^{\prime} 58^{\prime \prime}$ & 10 & 4 & 14 & Espaço Cultural \\
\hline 25.08 & $27^{\prime} 16^{\prime \prime}$ & 6 & 6 & 12 & Playground \\
\hline 04.09 & $53^{\prime} 45^{\prime \prime}$ & 27 & 12 & 39 & Sala de aula \\
\hline 15.09 & $45^{\prime} 01^{\prime \prime}$ & 7 & 6 & 13 & Sala de aula \\
\hline 18.09 & $06^{\prime} 50^{\prime \prime}$ & 3 & 1 & 4 & Playground \\
\hline 25.09 & $40 ’ 24$ ', & 3 & 4 & 7 & Sala de aula \\
\hline 29.09 & $57^{\prime} 26^{\prime \prime}$ & 22 & 8 & 30 & Sala de aula \\
\hline 03.10 & $47^{\prime} 06^{\prime \prime}$ & 11 & 11 & 22 & Espaço Cultural \\
\hline 09.10 & $40^{\prime} 40^{\prime \prime}$ & 8 & 2 & 10 & Sala de aula \\
\hline 13.10 & $34^{\prime} 40^{\prime \prime}$ & 21 & 06 & 27 & Sala de aula \\
\hline 28.10 & $32^{\prime} 00^{\prime \prime}$ & 6 & 3 & 9 & Sala de aula \\
\hline 05.11 & $53 ' 23{ }^{\prime \prime}$ & 20 & 8 & 28 & Brinquedoteca \\
\hline 17.11 & $36^{\prime} 12^{\prime \prime}$ & 8 & 5 & 13 & Educação Física \\
\hline 01.12 & $33^{\prime} 50^{\prime \prime}$ & 4 & 9 & 13 & Brinquedoteca \\
\hline 12.12 & $21^{\prime \prime} 00^{\prime \prime}$ & 12 & 6 & 18 & Sala de aula \\
\hline
\end{tabular}

Ao longo dessa primeira fase de análises, também foi possível identificar que, assim como no Caso Inácio, Ivan também almeja e busca entrar em contato com seus pares, uma vez que $62 \%$ das iniciativas de contato partem dele. Interesse esse que, apesar de manifestado em menor intensidade (cerca de 38\%), também é mútuo, veja na tabela 8 abaixo.

Tabela 8 - Quantitativo dos episódios de contato físico entre as crianças na fase I de análise - caso Ivan.

\begin{tabular}{ll}
\hline Situação & Análise quantitativa \\
\hline Total de situações de interação & $337-(100 \%)$ \\
Interações inciadas por Ivan & $207-(61,49 \%)$ \\
Interações iniciadas por demais colegas & $130-(38,51 \%)$ \\
\hline
\end{tabular}

Através da análise dos dados, novamente encontra-se a situação de que em contexto de sala de aula, majoritariamente, os contatos físicos ocorrem a partir da criança pivô. E o inverso se dá em momentoslcontextos fora da sala como, por exemplo, no playground. A semelhança nos resultados analisados entre os casos Inácio e Ivan, pode ter relação com o fato de ambos pertencerem a mesma instituição de ensino, cujo currículo e práticas pedagógicas seguem o mesmo princípio e as regras de conduta, horários da rotina escolar, material e espaço físico são os mesmos.

$\mathrm{Na}$ análise mais detalhada dos contatos físicos expressados em ambos os espaços (sala de aula e playground), identifica-se que na sala de aula os contatos circunscrevem situações: de simples 
necessidade de manutenção de elo, Ivan mantém sua mão no braço do colega ao lado durante o período em que eles assistem ao vídeo proposto pela professora. Não é identificado nenhum tipo de movimento específico (figura 11); para averiguar algo que lhe chama a atenção (figura 12), muito recorrente nesses momentos, Ivan está sentado no colo de uma das monitoras; para realizar alguma ação específica em direção aos pares, orientada pela professora ou pelas monitoras (figura 13); para chamar a atenção dos colegas e propor brincadeiras (figura 14); para manifestar contentamento ao ver o colega, como por exemplo no momento de entrada na sala de aula (figura 15); na divisão de objetos (figura 16); na disputa de objetos (figura 17); ou ainda nos momentos de conflito em que há expressão de empurrões elou tapas (figura 18).

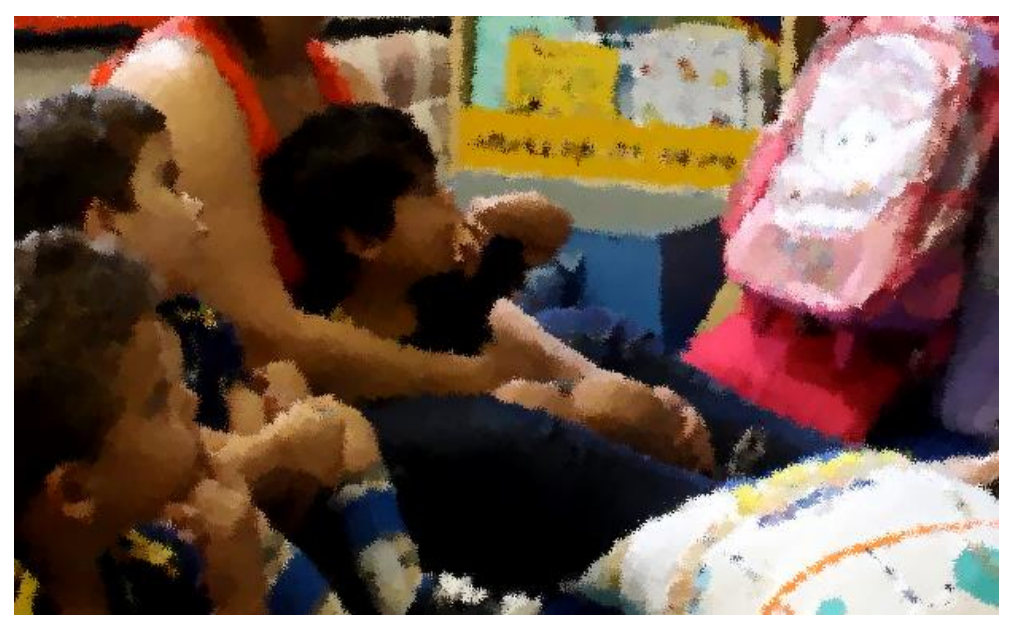

Figura 11. Ivan coloca sua mão no braço de João Paulo.

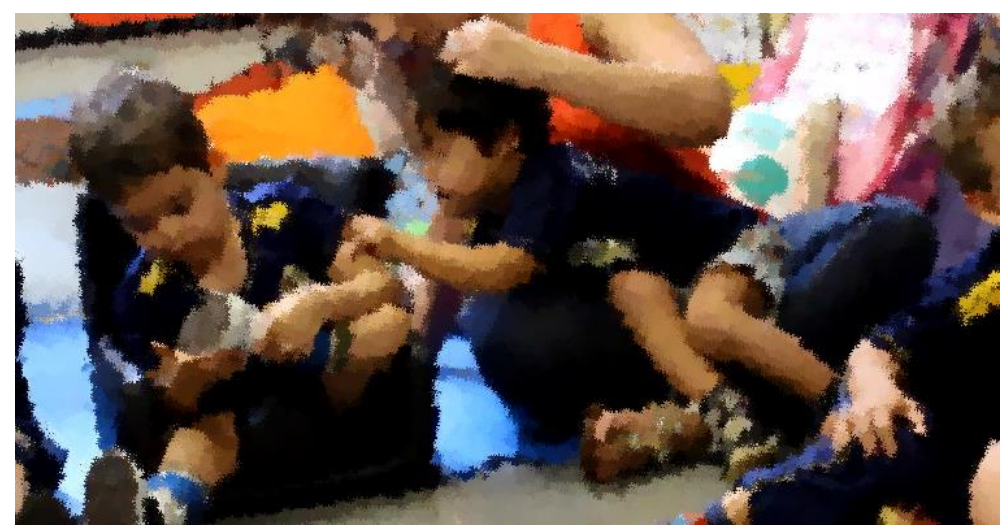

Figura 12. Ivan passa o dedo por dentro da blusa de João Paulo. 


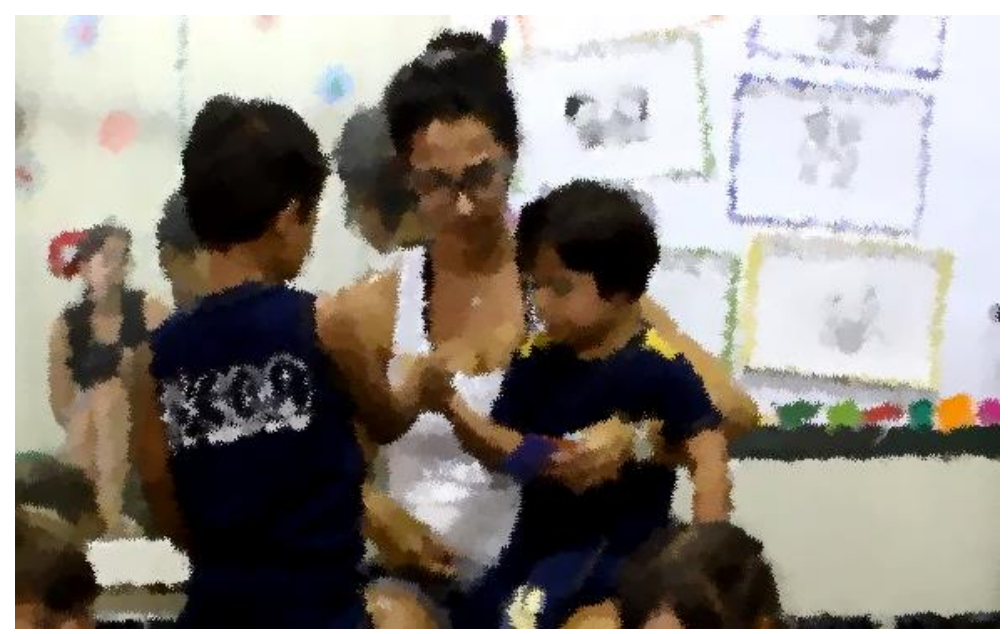

Figura 13. Ivan entrega as fichas coloridas da atividade do espaço cultural a pedido da professora, enquanto permanece sentado em seu colo.

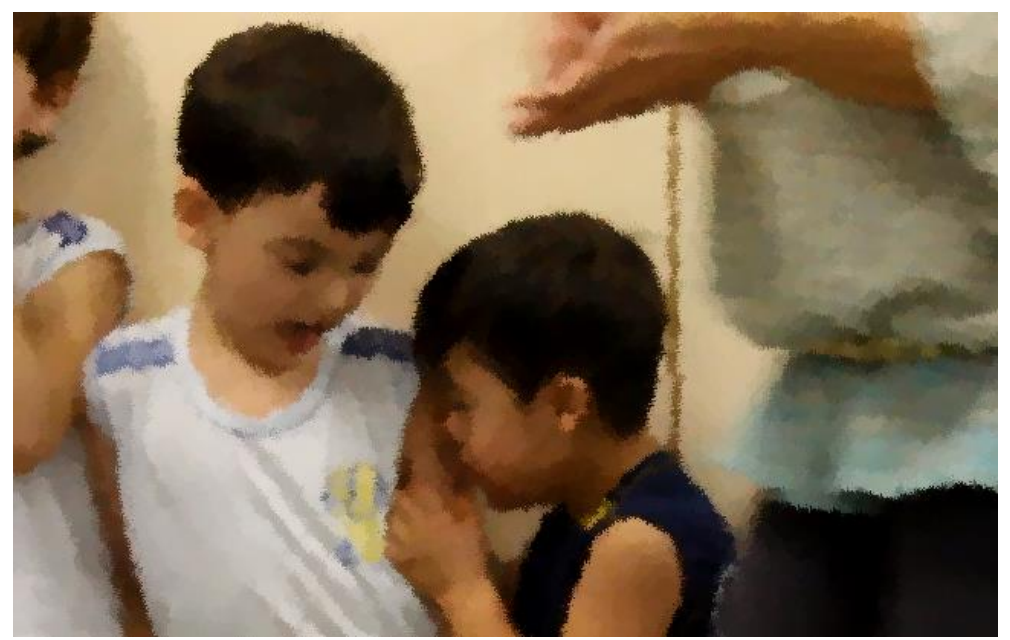

Figura 14. Ivan esfrega seu rosto no braço de Nicolas e sorri.

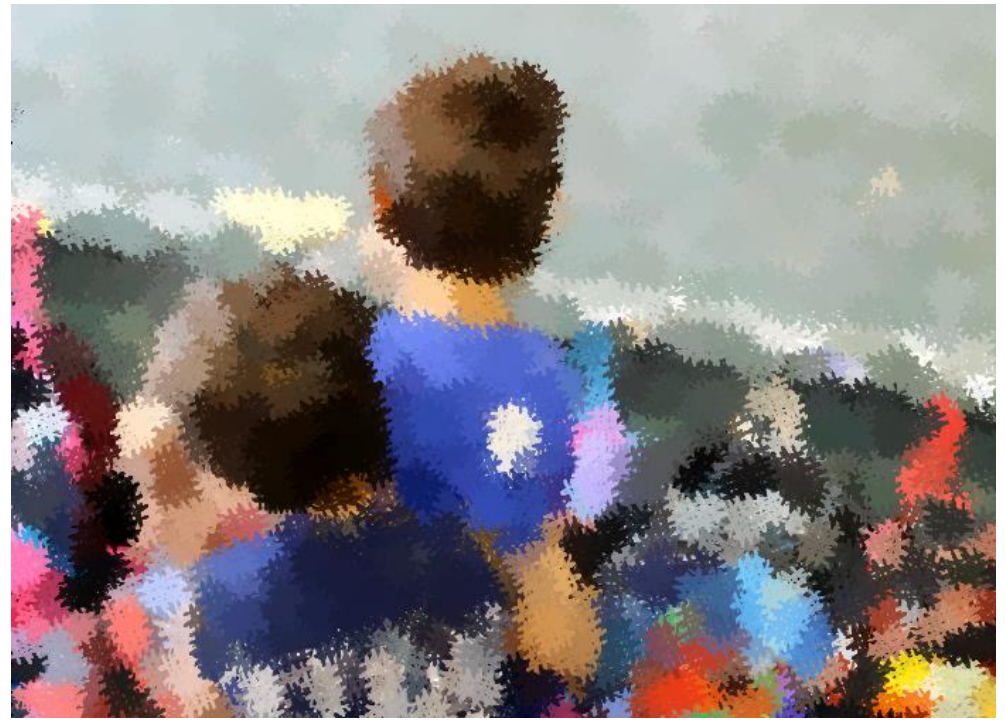

Figura 15. Ivan abraça Luis na entrada da sala. 


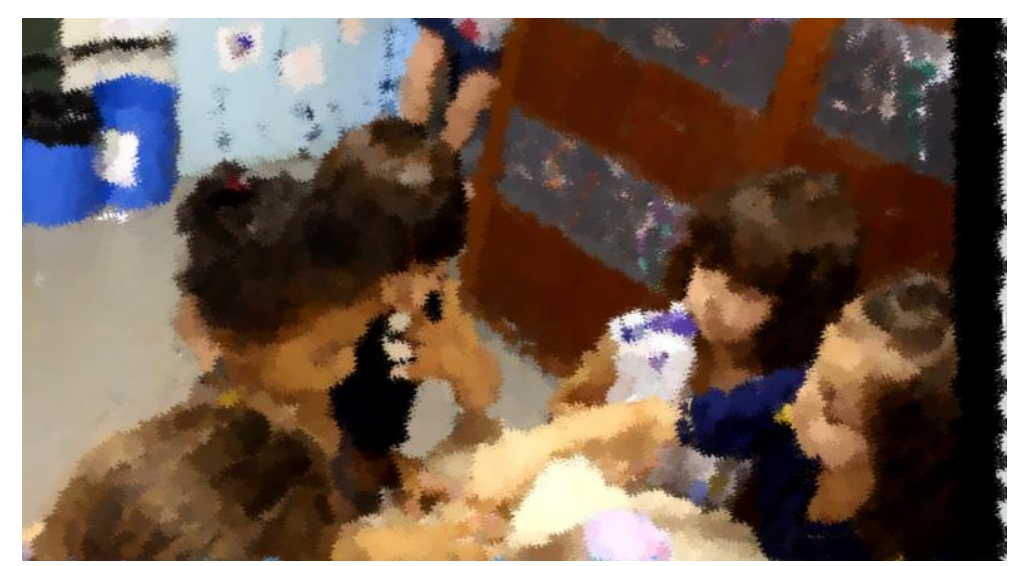

Figura 16. Ivan divide o pote de sorvete com outras colegas de sala.

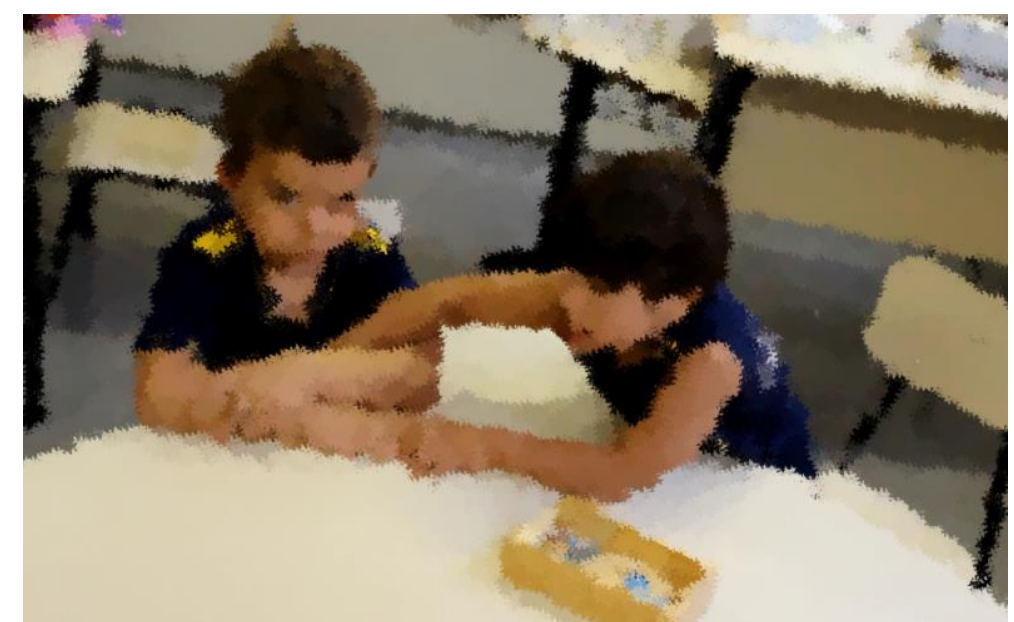

Figura 17. Ivan tenta pegar as fichas que estão com Eduardo. Eduardo as segura perto de si evitando que o colega consiga pegá-las.

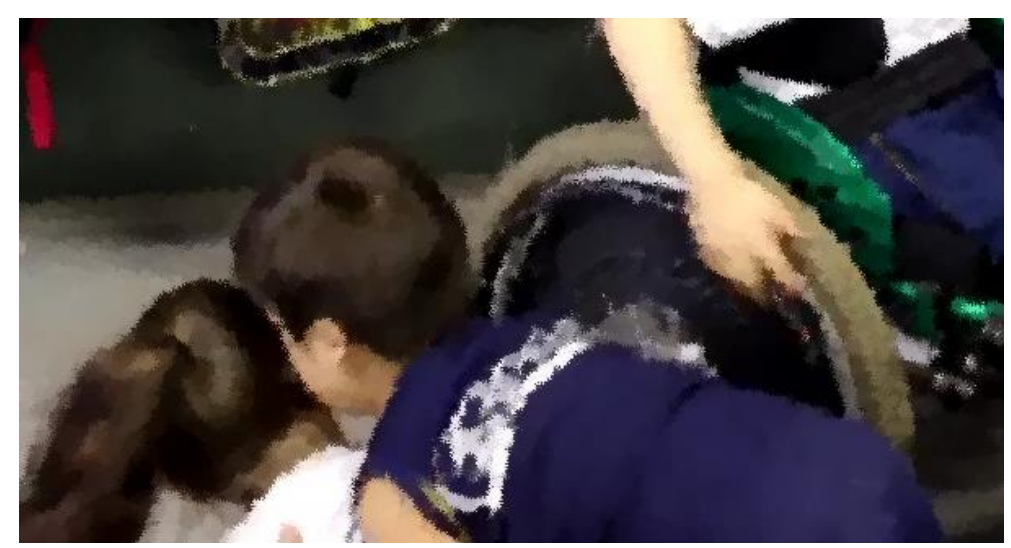

Figura 18. Ivan empurra e bate em Carla após ela tentar se aproximar de João Paulo enquanto Ivan brincava com ele.

Assim como no caso Inácio, para Ivan também não foi identificada nenhuma relação direta entre o tipo de atividade orientada desenvolvida na sala de aula e a incidência de contatos físicos; ou seja, não houve uma atividade específica em que fosse identificado um número maior de contatos físicos entre as crianças. Para Ivan, o contato físico na sala de aula circunscreve, portanto, situações que dizem respeito ao estar junto com o par, e não necessariamente no realizar atividades pedagógicas 
conjuntamente. Uma hipótese levantada é que esse fator tenha relação com o fato de Ivan contar com uma monitora o tempo todo com ele, diferente de Inácio, em que a monitora o assistia, mas suas obrigações não se restringiam a criança pivô. Dessa forma, as atividades orientadas são mediadas pela monitora e poucos são os espaços para a interação de pares ao longo da realização dessas atividades, fossem os contatos provenientes de Ivan ou dos pares. Os contatos físicos acontecem preponderantemente nos intervalos entre as atividades (e.g., momento de entrada, fila para locomoção para outras áreas da escola, momentos de atividade com jogos na sala de aula), nesses momentos, Ivan tem uma maior liberdade tanto nas ações como no direcionamento de com que par interagir.

Importante destacar que a intervenção das monitoras e, em algumas situações, da professora, se dá também por meio do contato físico, seja ele pelo posicionamento de Ivan entre seus braços (limitando o alcance da criança), no colo, ou ainda por meio de segurar as mãos de Ivan para que ele não manifeste o comportamento não aprovado como, por exemplo, bater no colega.

Já no playground os contatos físicos, além de terem maior incidência com a iniciativa dos pares, ao invés de Ivan, também circunscrevem situações diferentes. Os contatos físicos são expressados para: consolar ou afagar a dor de pequenos acidentes entre as crianças (figura 19); prestar socorro a Ivan durante as atividades nos diferentes brinquedos (figura 20); auxiliar a criança pivô nas suas dificuldades (figura 21); em situações de conflito de pares (figura 22); ou ainda, para chamar atenção de Ivan para a organização de atividades que desencadeiam brincadeiras próprias desse grupo de crianças (figura 23).

A partir da análise dos contatos físicos no playground é importante destacar que Ivan é uma criança que buscou utilizar de forma ampla e irrestrita todos os espaços a ele disponibilizados, independente da companhia. Dessa forma, não é identificada nenhuma busca por pares específicos, mas sim uma locomoção entre os diferentes espaços do playground. Outro fator importante é que no playground Ivan não era assistido pela monitora, podendo locomover-se com total liberdade entre os brinquedos e interagir com os pares sem mediação. Os pares também se encontram livres para se aproximarem mais de Ivan, o que possivelmente explica o maior número de contatos físicos iniciados por pares neste contexto. 


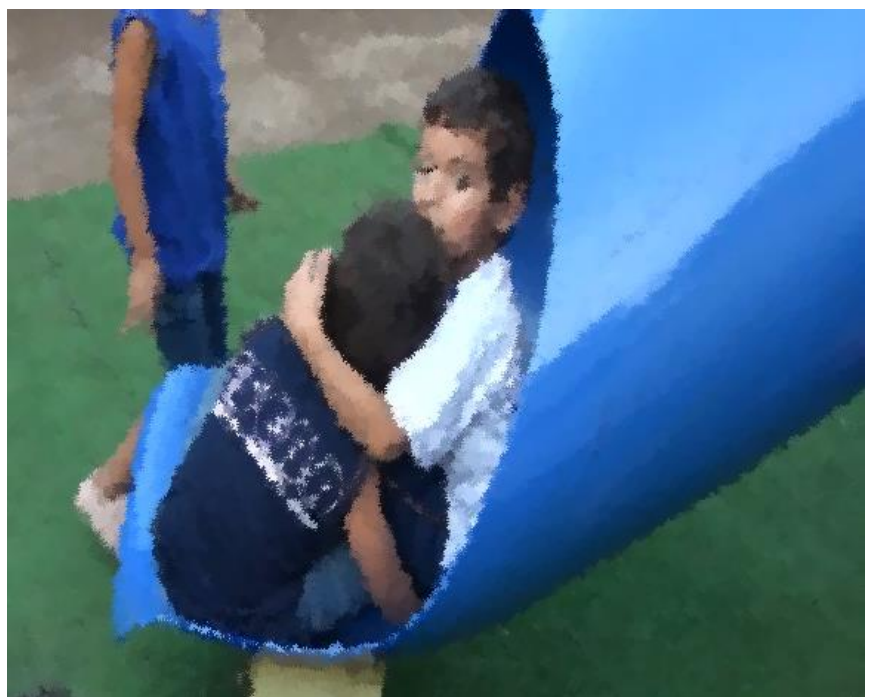

Figura 19. Luis abraça Ivan após vê-lo chorar.

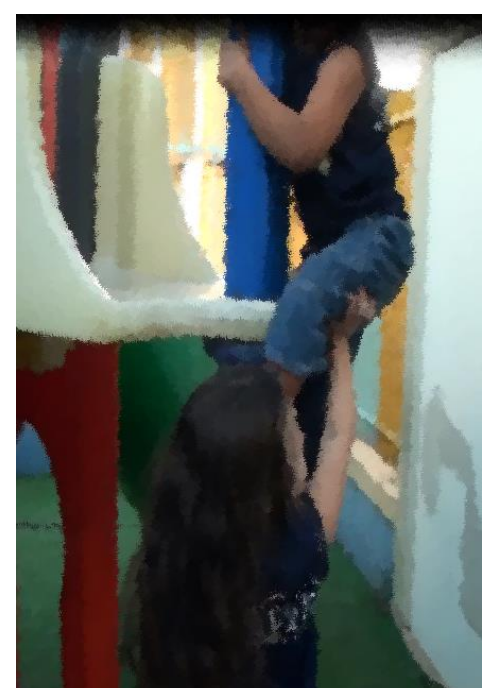

Figura 20. Carla ajuda Ivan a subir no escorregador através do poste.

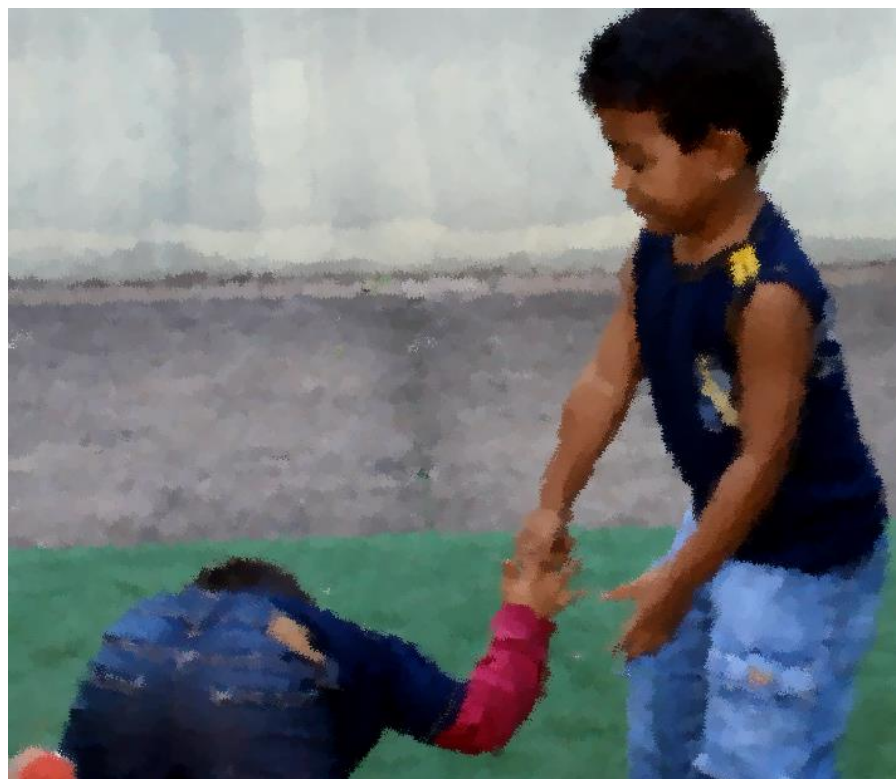

Figura 21. Otávio ajuda Ivan a se levantar após cair do escorregados. 


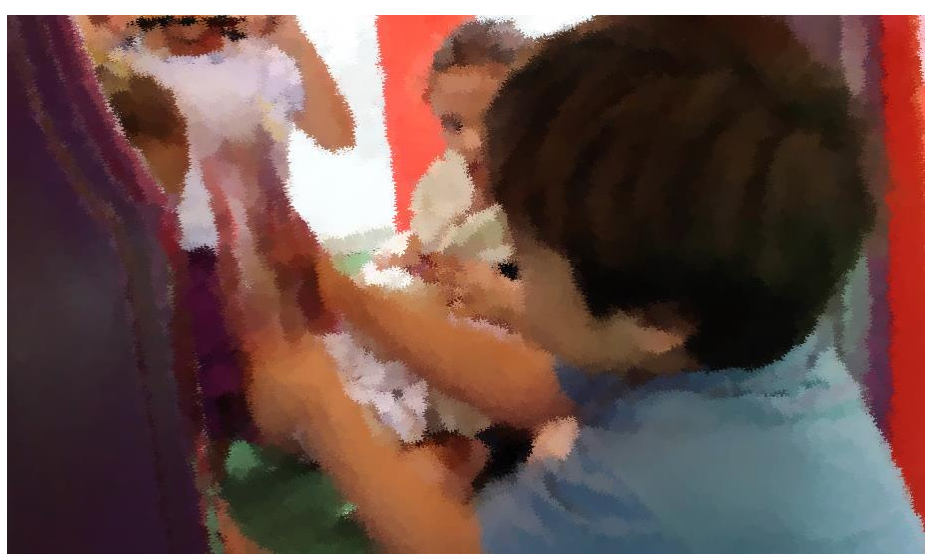

Figura 22. Ivan bate na cabeça de Carla com uma garrafa PET.

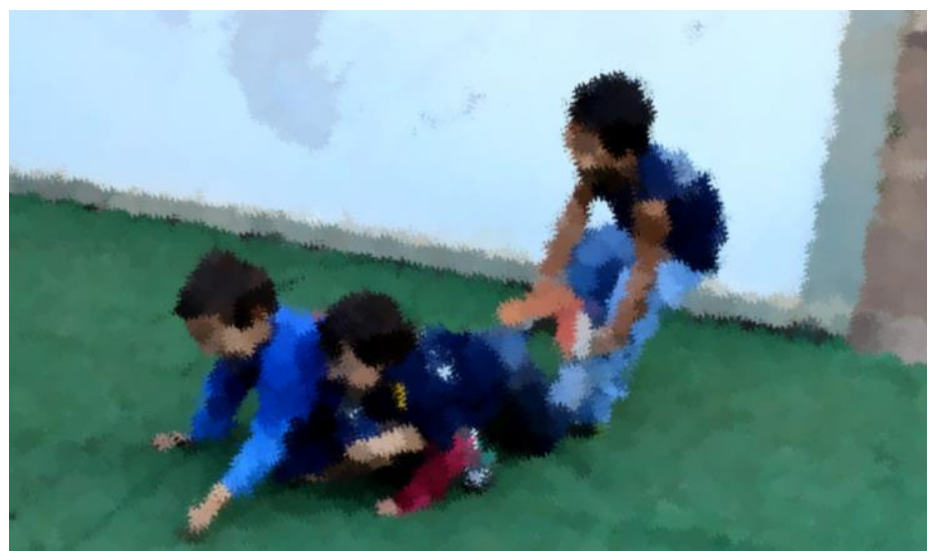

Figura 23. Otávio, Luis e Ivan brincam juntos de segurar um ao outro.

No playground, Ivan experimenta o contato físico de forma mais intensa, com episódios mais longos (as crianças mantêm-se em contato por um período maior de tempo) e em meio a situações de atividade coletiva livre que permitem a expressão corporal com maior desenvoltura e utilização de diferentes formas de entrar em contato (e.g., rolando no chão, sobrepondo-se ao colega dentro do escorregador, usando o colega como apoio para determinados movimentos, dentro outros). Essa liberdade proporcionada pelo espaço aberto e pela possibilidade de as crianças criarem seu próprio processo de utilização desse espaço, viabiliza Ivan a experimentar seu corpo e as possibilidades do corpo do par de forma diferente daquelas na sala de aula, muitas vezes envolvendo mais de um par ao mesmo tempo.

Ao longo das análises dos contatos físicos em todos os espaços da escola no estudo de caso de Ivan, não é identificado um elemento que fosse recorrente nas situações de interação, como no caso de Inácio. Ao contrário, o que chama a atenção nas análises das quantidades e conteúdo das situações em que foram registrados os contatos físicos de Ivan é a sua diversidade. Todavia, as análises do estudo de caso Ivan, diferente do estudo de caso Inácio, resultaram na identificação de nove episódios em que as situações de conflito entre pares resultou em machucados (beliscão e tapas). Essas situações de conflito estiveram circunscritas em processos de disputa pela utilização do 
brinquedo (e.g., disputa por um lugar no escorregador, disputa por bonecos de plástico), na reação de Ivan a ação de outros pares (Ivan é empurrado por Pedro e então ele o belisca), ou em situações em que não se identifica o motivo da ação (tapa) em si, mas se relaciona o episódio à presença de um par específico - Carla. Em todas essas nove situações a interferência do adulto fora imediata e no sentido de solicitar reparo emocional (que Ivan peça desculpas aos colegas). O comportamento contrário (colegas beliscando ou batendo em Ivan) não foram registrados.

Embora um quantitativo de nove episódios dentro de um contexto de 337 possa não ser significativo, considera-se ainda representativo das possibilidades de estar com o outro e manifestarse enquanto sujeito dessa criança; parte da ambiguidade e contradição do ser humano e da diversidade que é presente neste estudo de caso específico. Dessa forma, apresenta-se abaixo um episódio de interação em que são estabelecidos contatos físicos com finalidades distintas e, até mesmo, contraditórias e, em que um desses contatos é realizado por meio de comportamentos que causam machucado (empurrão e tapa).

\section{Ivan em: "Entre tapas e beijos"}

\section{Data: 09 de outubro de 2014, gravação n.3 aos 3'}

Contexto geral: As crianças estão na sala de aula e a professora organizou quatro cantos da sala com atividades diferentes. As crianças se agruparam livremente nos quatro cantos e escolheram as atividades que gostariam de fazer. Nesta cena, Ivan está interagindo com João Paulo, que inicialmente estava fazendo uma atividade de colagem com a ajuda da monitora da turma.

Descrição da cena: Ivan levanta-se da sua cadeira e movimenta-se em direção a João Paulo, Ivan puxa a cadeira de rodas do colega retirando-o de perto da mesa e abrindo espaço para lhe dar um abraço. Ivan abraça João Paulo, que por sua vez permanece parado recebendo o abraço. Ivan vira a cadeira do colega e beija-lhe o rosto. João Paulo usa seus braços com movimento lentos para afastar Ivan. Ivan olha para João Paulo e abraça-o novamente, João Paulo retribui o braço e ambos permanecem por alguns instantes abraçados. Carla olha para os dois e se aproxima, pega na mão de João Paulo e também lhe faz carinho. Ivan estende sua mão em direção contrária impedindo que Carla se aproxime mais. João Paulo olha para Carla, que continua a segurar sua mão. Ivan pega na mão de João e puxa-o em direção oposta, mas João não se move da cadeira. Ivan aproxima-se de Carla empurra-a contra o chão e lhe profere três tapas. A professora fala em tom de ordem "Ivan, assim não. Não pode!". Ivan faz um sinal de não com os dedos e com a cabeça, balançando-a de um lado para outro, vira em direção a João Paulo e volta a abraçar o colega. A professora fala para Ivan que ele está no grupo da leitura e que ele tem então que pegar um livro. Ivan caminha em direção a estante de livros e pega um, volta e mostra o livro para João Paulo. Ivan senta no chão, segura na cadeira de rodas do colega, puxa-a para mais perto de si e começa a folhear o livro. João Paulo movimenta a cadeira em direção oposta, saindo do alinhamento feito pelo colega. Ivan levanta-se mostra o livro para João Paulo e puxa sua cadeira novamente em direção a si. A monitora fala para João Paulo que Ivan está tentando ler uma história para ele e fala que ele pode fazer a 
colagem depois. Ivan posiciona-se na frente da cadeira de rodas mais uma vez e puxa o colega para perto de si, senta na cadeira, abre o livro e começa a folheá-lo. João Paulo olha para Ivan.

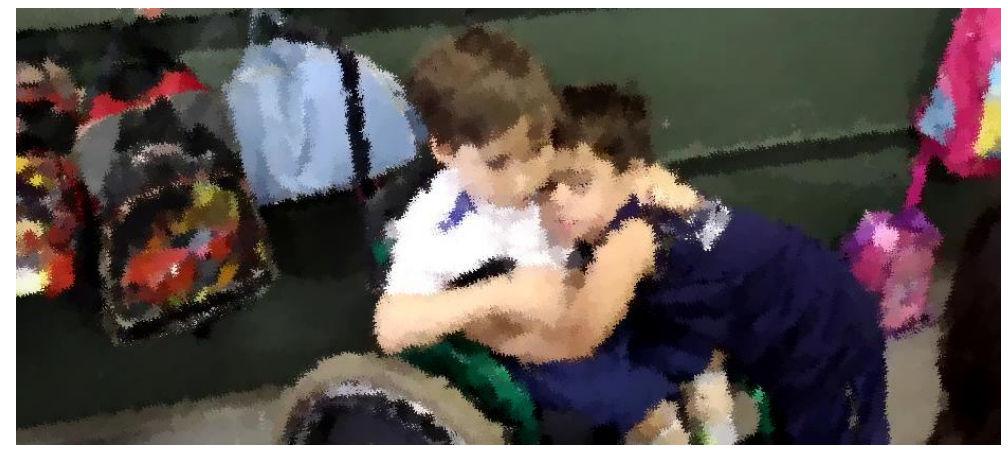

Figura 24. Ivan abraça João Paulo.

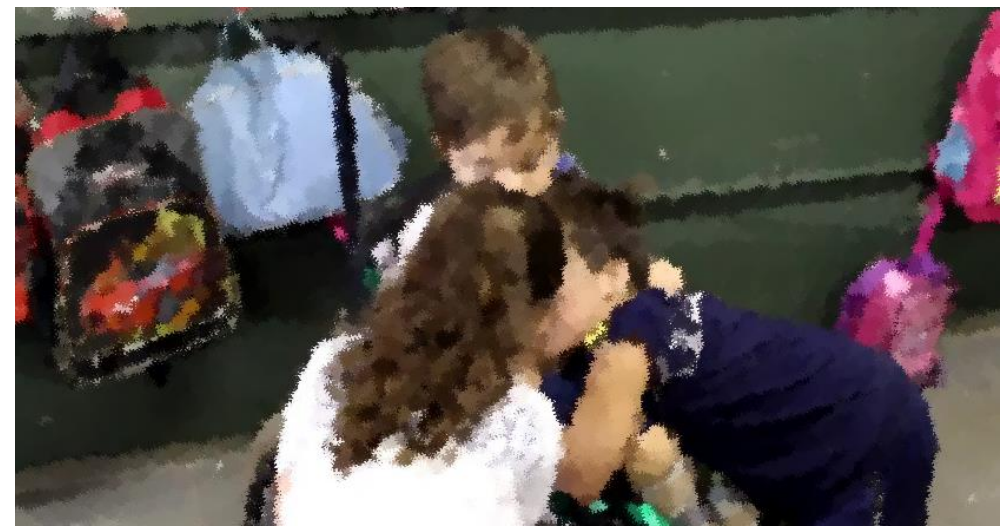

Figura 25. Carla se aproxima e tenta abraçar João Paulo também. Ivan a empurra.

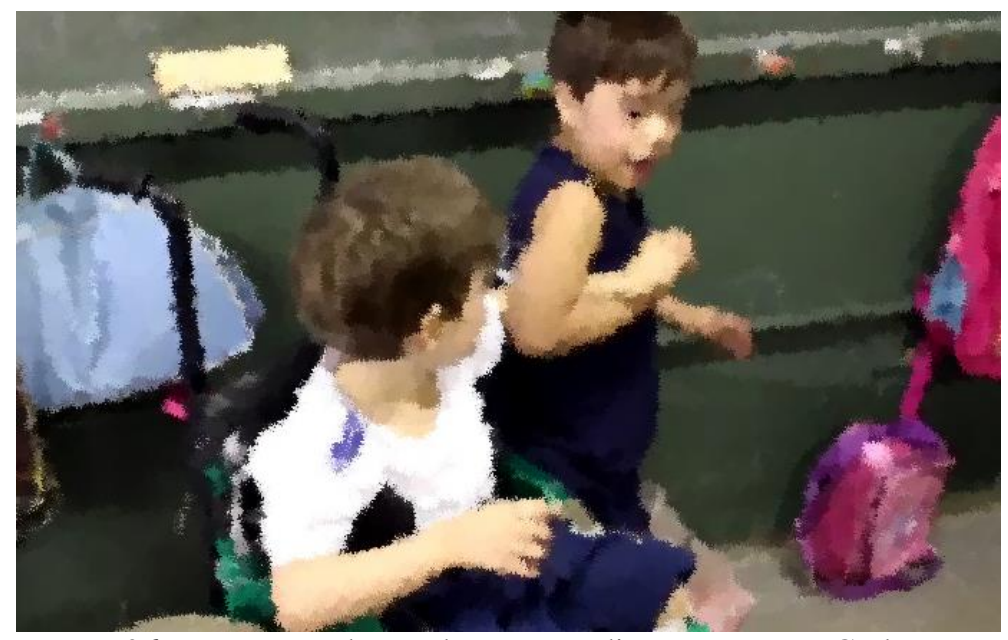

Figura 26. Ivan puxa o braço de João em direção oposta a Carla. 


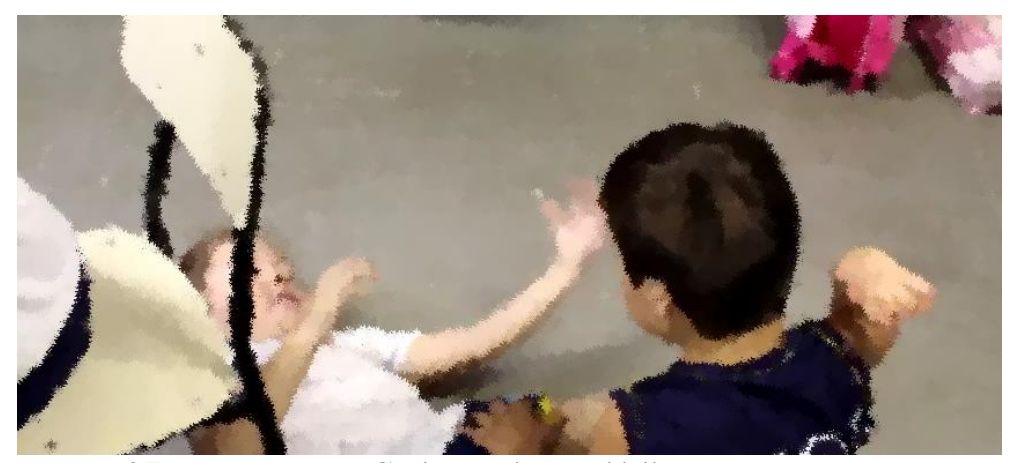

Figura 27. Ivan empurra Carla no chão e dá-lhe um tapa.

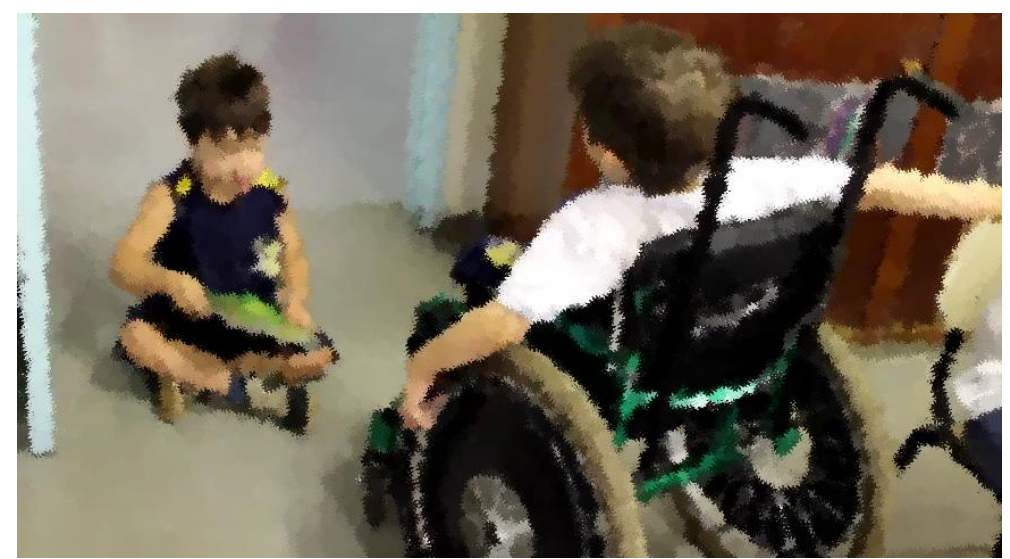

Figura 28. Ivan lê um livro para João.

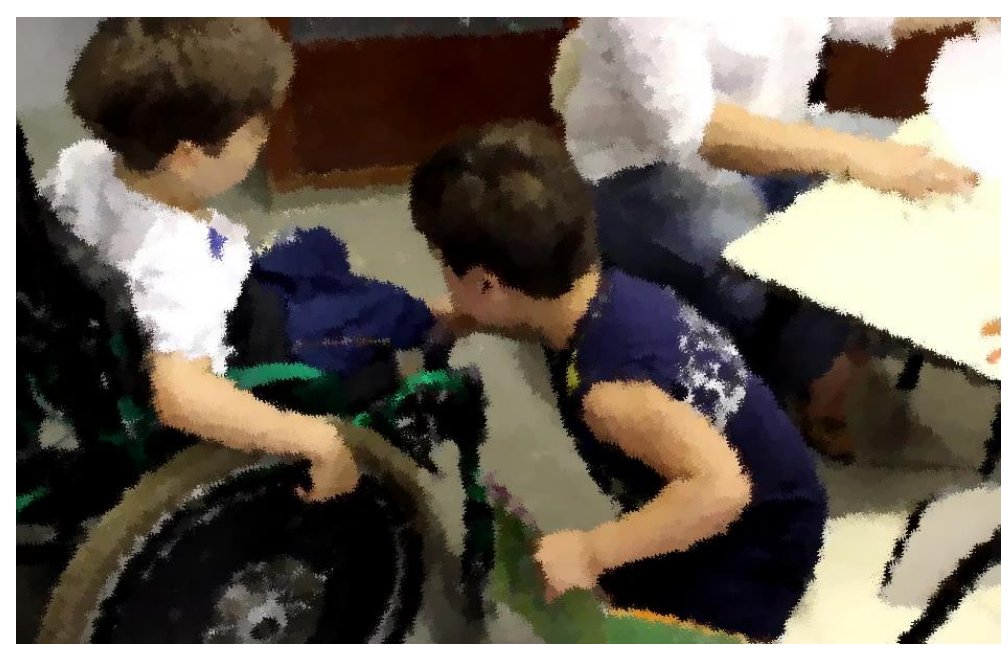

Figura 29. Ivan puxa a cadeira de João posicionando-a perto de si.

Os contatos físicos explicitados nesta cena são constantes e parte integrante da construção da atividade conjunta, ou seja, revelam a intenção de Ivan (interpretada pela monitora como o desejo de ler o livro para o colega) no fazer com João Paulo e também possibilitam que a ação conjunta aconteça, uma vez que embora esse contato físico venha acompanhado de outros elementos: a atenção conjunta (Baldwin, 1995), os gestos ritualizados ou idiossincráticos (Pedrosa \& Carvalho, 2006) e o contato direto de Ivan, puxando a cadeira de rodas, segurando o rosto do colega, pegando pelas mãos que direcionam não só a atenção de João, mas também a posição do seu corpo, e vai construindo o 
processo interativo na expressão do desejo de um fazer conjunto. O contato físico é, portanto, o elemento que, neste episódio, abre espaço e mantém a interação dos pares.

Ao mesmo tempo, quando da aproximação de Carla à díade João-Ivan, o contato físico não mais expressa um movimento de fazer conjunto, ao contrário, exclui e explicita a recusa da participação desse terceiro. Os contatos que se dão com o par Carla acontecem através de um conjunto de comportamentos que vão afastá-la da situação inicial estabelecida com João (Ivan debruça sobre o colo de João, colocando-se entre ele e Carla) e puni-la pela sua tentativa (Ivan empurra a colega ao chão, lhe proferindo tapas), criando uma situação em que essa criança não mais deseje fazer parte da díade. O contato físico agora é usado para impedir um fazer conjunto.

Frequentemente, os contatos físicos por comportamentos dessa natureza são julgados como socialmente inadequados, sem um olhar específico sobre a situação em que eles emergem e categorizados enquanto problemas de comportamento. Estudos recentes envolvendo crianças com deficiência apontam que, casos com diagnóstico específico de Síndrome de Down apresentam um número menor de indicadores de problemas de comportamento, se comparados a casos com outros diagnósticos e comorbidades como, por exemplo, a paralisia cerebral ou epilepsia (Hattier, Matson, Belva, \& Kozlowski, 2012). Apesar de menor prevalência, comportamentos que resultam em dano físico (tapa, empurrões, beliscões e etc.) são fontes de preocupação para muito professores (Rose, 2010), demandando múltiplos esforços para uma intervenção que de fato contribua para o desenvolvimento da criança (Embregts, Du Bois \& Graef, 2010).

Neste trabalho, o enfoque não é categorizar o tipo de comportamento que o contato físico estabelece, mas se entender no que esse contato permite (ou limita) para a interação de pares. Nesse sentido, chama-se atenção para a explicação de Wallon (1995) sobre o aparecimento de manifestações de emoções como o ciúme e a simpatia. Para Wallon, "o estado de fusão com o outro, expresso por uma situação afetiva, explica manifestações aparentemente muito complexas, porém de aparecimento precoce, tais como o ciúme e a simpatia" (Wallon, 1995, p.240), sendo necessário ainda considerar que

“(...) a simpatia pode se manifestar a princípio em dois sentidos contrários: centrífugo e centrípeto. No primeiro caso, a criança transfere o objeto habitual de seus próprios desejos ou de seus temores para quem suscitou sua compaixão. (...) $\mathrm{Na}$ forma centrípeta, ela reage àquilo que interessa ou ameaça a outra, como se tratasse dela própria" (Wallon, 1995, p.244). 
Dessa forma, o entendimento que se constrói a partir desse episódio é que os contatos físicos são também caminhos de expressão dos desejos e emoções da criança; são elementos importantes para o processo de diferenciação Euloutro, tão fundamental para a constituição social propriamente humana. Os contatos físicos, enquanto expressões do sujeito, não acontecem descontextualizados de um processo de desenvolvimento em curso, mas são, sim, parte dele e para entendê-los tem que se olhar para dinâmica interativa.

\section{Caso Amanda}

No caso da Amanda, foi analisado um total de 1054 minutos e 30 segundos, pelos quais identificou-se um total de 468 situações de contato físico, sendo que 259 situações foram iniciadas por Amanda e 209 pelos demais colegas.

Tabela 9 - Quantitativo dos episódios de contato físico entre as crianças na fase I de análise - Estudo de caso Amanda.

\begin{tabular}{ll}
\hline Situação & Análise quantitativa \\
\hline Total de situações de interação & $502(100 \%)$ \\
Interações iniciadas por Amanda & $277(55,2 \%)$ \\
Interações iniciadas por demais colegas & $225(44,8 \%)$ \\
\hline
\end{tabular}

Novamente, podemos observar que não há uma diferença significativa entre o número de contatos físicos iniciadas pela criança pivô e o número de interações iniciadas pelos pares de idade. Contudo quando se analisam os contatos físicos levando em consideração os espaços em que eles aconteceram, identifica-se que (1) no teatro, de uma forma geral, é Amanda quem busca pelo contato com maior frequência (63x24); (2) na sala de aula, embora o quantitativo total de contatos aponte equilíbrio entre as iniciativas de Amanda e as de seus pares (92x91), encontra-se discrepância em determinados dias (no dia 21/05, 18x4 - no dia 06/06, 06x20) que ora apontam para uma maior procura por parte de Amanda e ora parte dos colegas. Esse dado apontou que os tipos de atividades possivelmente interferissem na promoção da interação de pares para essa criança. Abaixo, na tabela 10, se dispõem os dados referentes aos demais contextos.

Tabela 10 - Dados gerais do mapeamento de situações de interação realizado na fase I - Estudo de caso Amanda

\begin{tabular}{cccccl}
\hline $\begin{array}{c}\text { Data do vídeo } \\
\text { registro }\end{array}$ & $\begin{array}{c}\text { Tempo total } \\
\text { analisado }\end{array}$ & $\begin{array}{c}\text { Interações iniciadas } \\
\text { por Amanda }\end{array}$ & $\begin{array}{c}\text { Interações iniciadas } \\
\text { por colegas }\end{array}$ & $\begin{array}{c}\text { Total de } \\
\text { interações }\end{array}$ & Local \\
\hline $\mathbf{2 1 . 0 5 . 2 0 1 4}$ & $49^{\prime} 50^{\prime}$ & 18 & 4 & 22 & Sala de aula \\
$\mathbf{2 3 . 0 5 . 2 0 1 4}$ & $80^{\prime}$ & 29 & 27 & 59 & Pátio
\end{tabular}




\begin{tabular}{lcccll}
$\mathbf{2 8 . 0 5 . 2 0 1 4}$ & $58^{\prime}$ & 19 & 9 & 28 & Pátio \\
$\mathbf{0 2 . 0 6 . 2 0 1 4}$ & $55^{\prime} 48^{\prime}$, & 21 & 14 & 35 & Sala de aula \\
$\mathbf{0 6 . 0 6 . 2 0 1 4}$ & $71^{\prime}$ & 06 & 20 & 26 & Sala de aula \\
$\mathbf{1 1 . 0 6 . 2 0 1 4}$ & $72^{\prime} 50^{\prime}$, & 34 & 18 & 52 & Teatro \\
$\mathbf{1 8 . 0 7 . 2 0 1 4}$ & $64^{\prime} 28^{\prime}$ & 21 & 19 & 40 & Sala de aula \\
$\mathbf{2 3 . 0 7 . 2 0 1 4}$ & $37^{\prime} 50^{\prime}$, & 07 & 10 & 17 & Pátio, em grupo \\
$\mathbf{3 0 . 0 7 . 2 0 1 4}$ & $70^{\prime} 46^{\prime}$, & 19 & 15 & 34 & Refeitório \\
$\mathbf{0 3 . 0 9 . 2 0 1 4}$ & $60^{\prime}$ & 06 & 9 & 15 & Sala de vídeo \\
$\mathbf{0 9 . 0 9 . 2 0 1 4}$ & $45^{\prime}$ & 29 & 6 & 35 & Teatro \\
$\mathbf{1 0 . 0 9 . 2 0 1 4}$ & $57^{\prime}$ & 08 & 13 & 21 & Sala de aula \\
$\mathbf{3 0 . 0 9 . 2 0 1 4}$ & $64^{\prime}$ & 15 & 18 & 33 & Pátio atividade em \\
$\mathbf{1 3 . 1 0 . 2 0 1 4}$ & $64^{\prime}$ & 15 & 21 & 36 & grupo \\
$\mathbf{2 0 . 1 0 . 2 0 1 4}$ & $58^{\prime}$ & 11 & 4 & 15 & Sala de aula \\
$\mathbf{1 0 . 1 1 . 2 0 1 4}$ & $58^{\prime}$ & 02 & 03 & 05 & Pátio e vídeo \\
$\mathbf{1 7 . 1 1 . 2 0 1 4}$ & $59^{\prime} 12^{\prime}$, & 08 & 11 & 19 & aula de \\
$\mathbf{0 8 . 1 2 . 2 0 1 4}$ & $29^{\prime}$ & 09 & 04 & 11 & Educação Física \\
& & & & & Educação Física e \\
\hline
\end{tabular}

Ao se olhar para as interações em sala de aula, particularmente considerando as discrepâncias encontradas nas análises quantitativas e, assim, investigando quais seriam os tipos de atividade que possivelmente acarretariam no maior envolvimento de Amanda em busca de contato físico de seus pares, foram identificados dois fatores importantes: (1) a atividade proposta pela professora nos dois dias; e, (2) a interferência do adulto, que se difere entre os dias de vídeo-registro.

No registro do dia 21 de maio, a atividade central proposta pela professora foi cantar músicas infantis na sala de aula, cuja organização é feita dentro dos limites de $35 \mathrm{~m}^{2}$. Nesses momentos, as crianças são posicionadas sentadas em suas cadeiras em círculo na sala de aula e, na medida em que a professora canta as crianças acompanham com os gestos e dançam (ver figura 30 abaixo). Amanda demonstrou grande interesse nesse tipo de atividade, participando do movimento do grupo e manifestando gestos (cópias simultâneas e ainda fragmentadas) de acordo com aqueles apresentados por seus pares e pela própria professora. Intercalado com os comportamentos imitativos, Amanda busca pelo par e os contatos físicos acontecem em meio a um processo de contágio emocional (Wallon, 1995; 2008), preponderantemente para chamar atenção dos demais colegas para o que está acontecendo, principalmente daqueles que estão logo a seu lado.

É importante destacar o papel da educadora nesse processo pois, embora ela tentasse fazer com que Amanda sempre permanecesse sentada, interferindo nos momentos em que Amanda busca pelo par, a educadora estava localizada a duas cadeiras de distância de Amanda, com limitado acesso à 
criança. A configuração da sala para a realização da atividade e o fato da educadora ter ficado relativamente afastada de Amanda, possivelmente tenha sido o que possibilitou que, mesmo com o monitoramento constante de suas ações, Amanda fosse capaz de buscar pelos pares. Ao mesmo tempo, o número relativamente menor de buscas por contatos pelos pares também se deu em decorrência dessa ser uma atividade que os envolve por completo.

Semelhante processo acontece nos dias de teatro; a criança pivô é contagiada pela apresentação das demais crianças, observando as demais crianças e busca pelo contato a todo o momento. As educadoras estão envolvidas com a organização da atividade e com um número maior de crianças presentes (nesse dia diferentes salas de aula participam da atividade ao mesmo tempo), o foco é, portanto, menor nas ações de Amanda. Nota-se ainda que todas as vezes que Amanda foi posicionada perto das educadoras (senta-se Amanda entre as pernas da educadora na tentativa de restringir sua locomoção), os pares vêm em sua direção e chamam-lhe para brincar. Esse brincar é permitido, desde que Amanda não se afaste do local onde foi colocada, quando Amanda se afasta a educadora imediatamente a reposiciona perto dela.

Já no dia seis de junho, o inverso acontece. São os pare que mais estabelecem situações de contato físico com Amanda no contexto da sala de aula. A atividade principal neste dia envolveu assistir um vídeo. Observou-se, pela análise dos vídeo-registros, que Amanda dispende grande concentração para esse tipo de atividade (ela olha constantemente para tela da TV) ao longo de todo o tempo, diminuindo o seu interesse pelas atividades com demais pares. Esse comportamento também foi observado nos pares. Ao longo do vídeo, as crianças interagem pouco entre si. Contudo, no restante do dia, o fator que determina as possibilidades de busca por contato físico é a presença constante e ininterrupta do adulto. No restante do tempo as educadoras estão a todo momento com Amanda, segurando sua mão, acompanhando sua locomoção e determinando a direção do seu foco de atenção. São as demais crianças que se aproximam de Amanda. Essa aproximação e o contato físico que advém dela foram marcados por dois tipos de contexto: (1) dar e trocar objetos com Amanda - as crianças traziam brinquedos para ela; e, (2) segurar na mão de Amanda ao longo dos trajetos dentro da escola (figura 31). A segunda situação aconteceu espontaneamente pela iniciativa de algumas crianças (destaque para Jéssica, que realiza essa ação duas vezes), ou pela orientação da própria educadora que pede para as crianças ao fazerem a fila segurarem na mão de Amanda. 


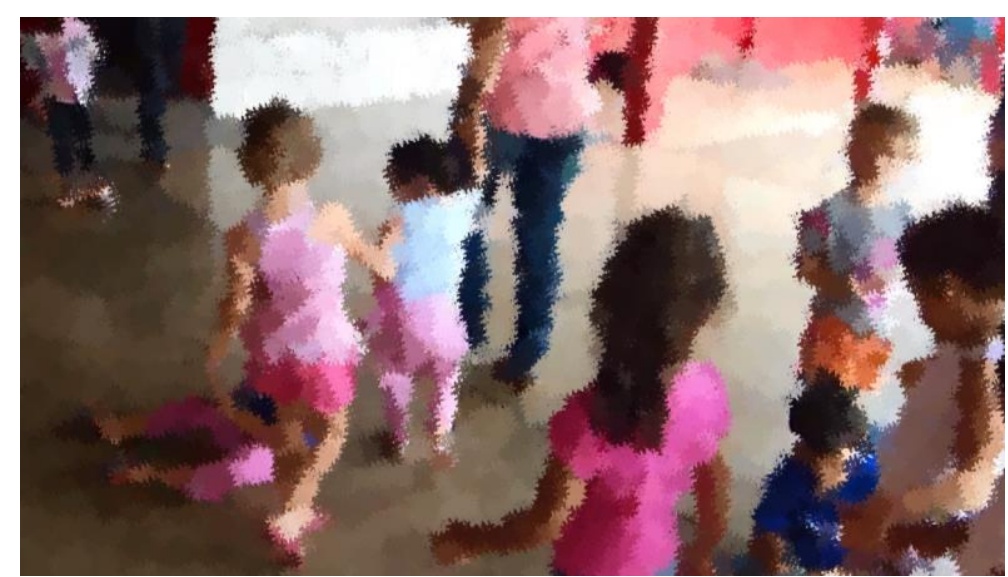

Figura 31. Jéssica e Amanda andam de mãos dados enquanto vão ao banheiro.

Contudo, considerando o conjunto total dos dados e analisando os episódios pela perspectiva do que acontece na situação de interação, ou seja, buscando identificar o papel dos contatos físicos na interação, identificou-se que os contatos acontecem: (1) para chamar a atenção do par (focalizar a atenção em si), isso acontece tanto por iniciativa de Amanda quanto pela iniciativa dos demais pares (figura 32); (2) em situações de conflito na disputa por brinquedos (figura 33); (3) para demarcar a divisão do espaço durante atividades coletivas (figura 34); (4) para manter contato com o colega ao longo de uma atividade em curso (figura 35); (5) para expressar afeto, podendo esse ser um afeto socialmente interpretado como positivo, beijo, ou um afeto socialmente interpretado como negativo, um tapa (figuras 36 e 37); ou ainda, (6) nos momentos de brincadeira conjunta (figura 38).

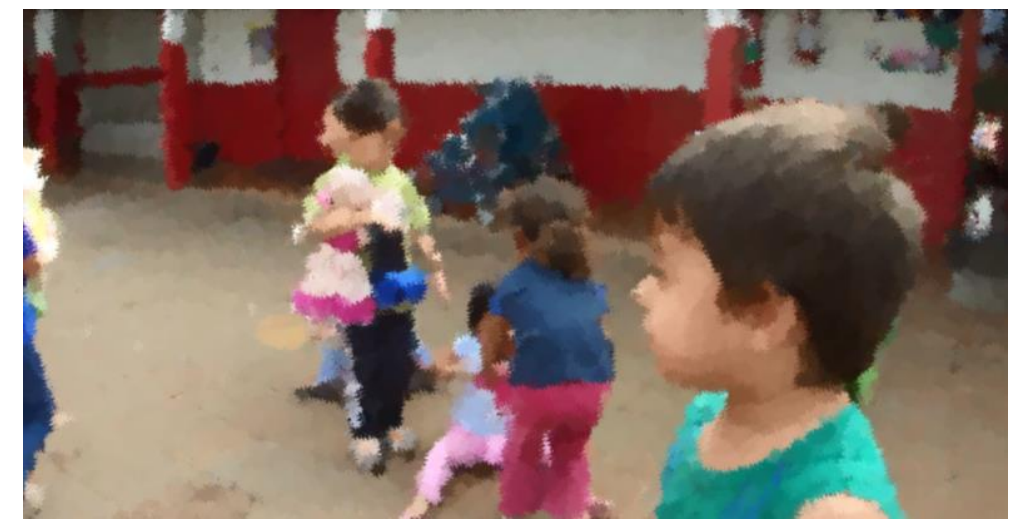

Figura 33. Amanda puxa a boneca da mão da colega Rafaela. 


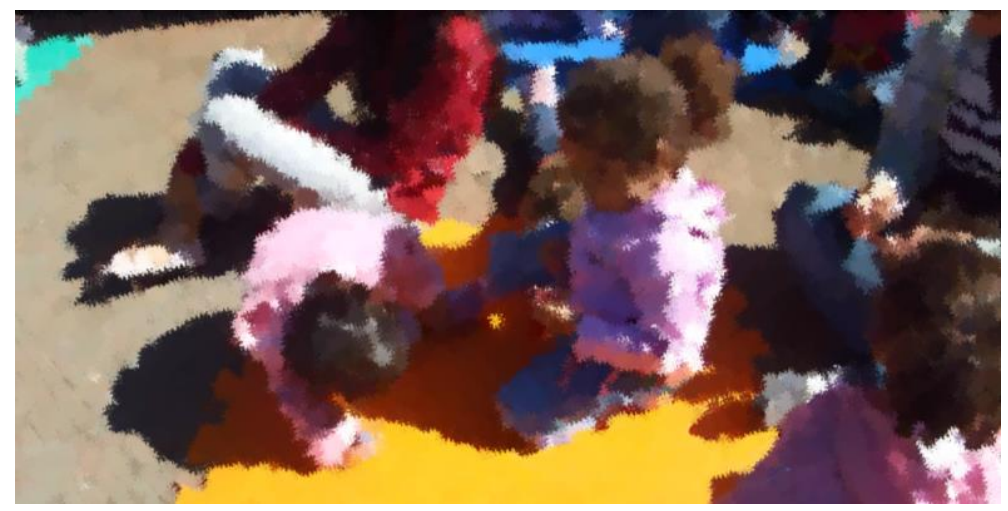

Figura 34. Amanda retira o pé de Letícia, abrindo espaço para que ela possa brincar.

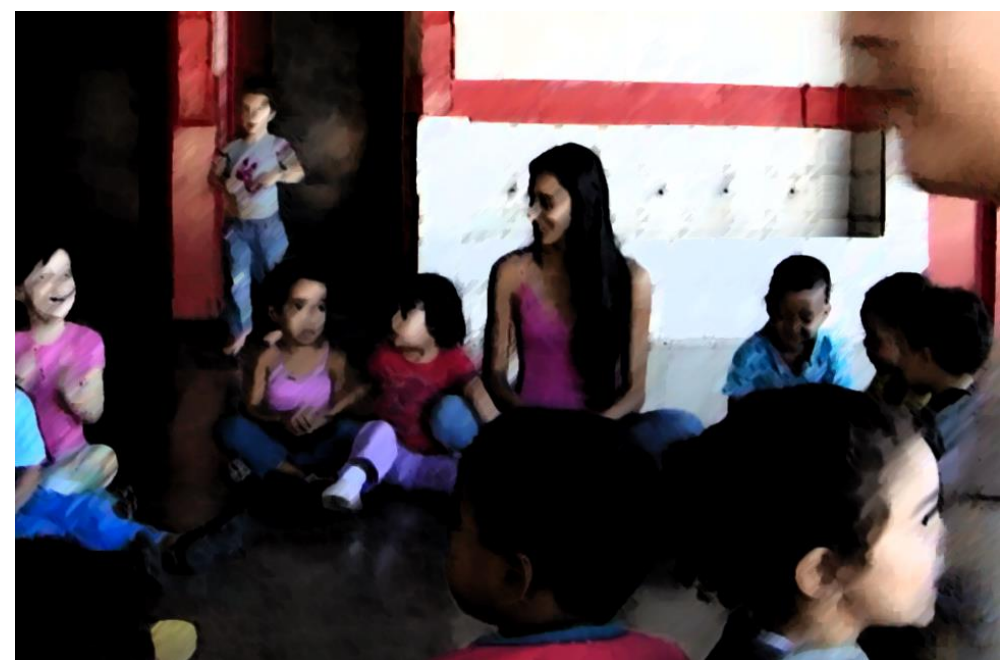

Figura 35. Amanda repousa sua mão no colo de Letícia ao longo de alguns instantes da atividade em curso.

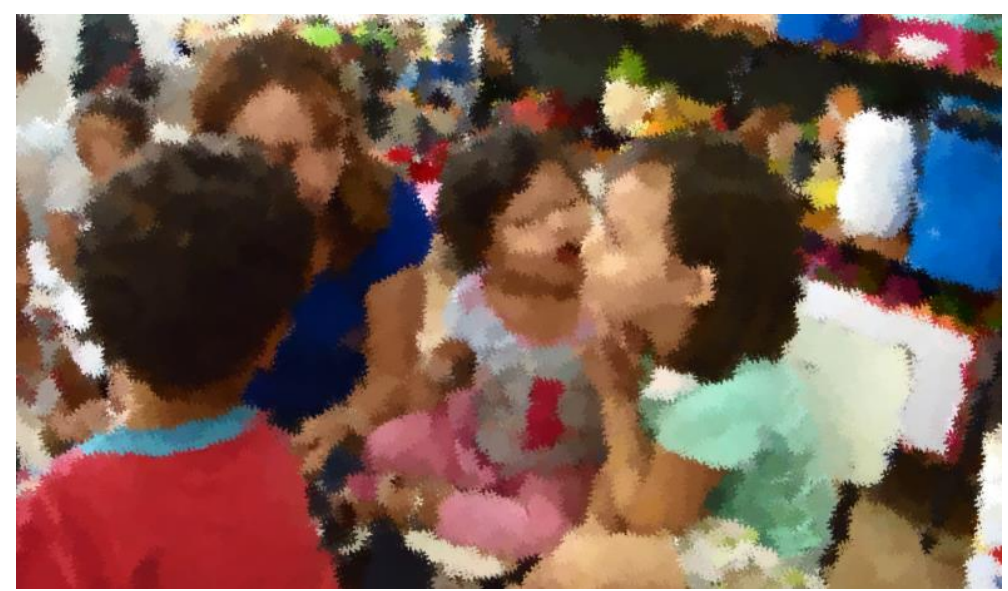

Figura 36. Amanda beija espontaneamente Isabela durante uma atividade de grupo. 


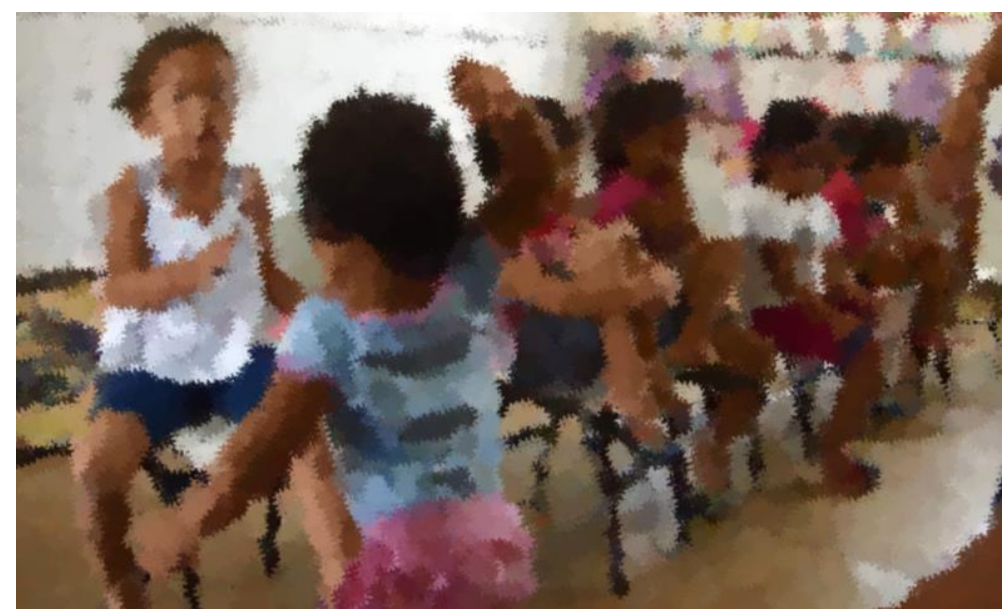

Figura 37. Amanda dá um tapa em Rafaela após ela ter sentado no seu lugar.

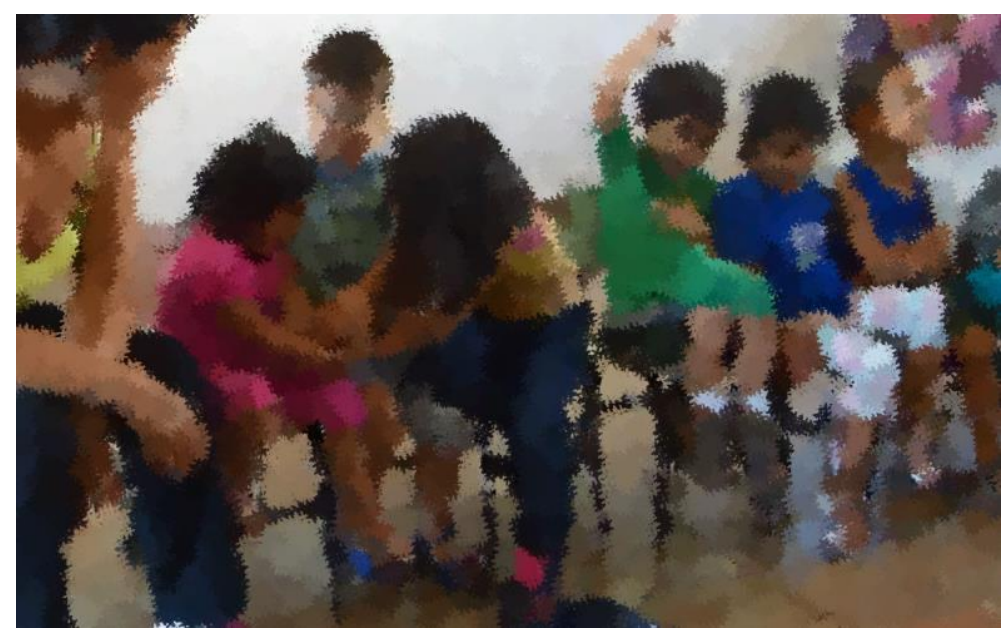

Figura 38. Amanda Letícia e Miguel brincam de colocar as mãos sobrepostas umas das outras enquanto esperam a atividade começar.

Identificou-se também no caso de Amanda, que o contato físico iniciado por ela foi em algumas situações negado ou rejeitado pelo par (figura 39). Essa ocasião foi registrada oito vezes a partir de comportamentos como o afastamento do par em direção oposta à de Amanda após a tentativa de contato advindo dela, o retraimento em seus lugares seguido da chamada pela educadora para retirar Amanda de perto delas. Em três dessas situações as expressões faciais das crianças indicam nojo ou repulsa (nariz franzido e boca curvada para baixo, acompanhado do retraimento do corpo na cadeira), o que muito possivelmente seja uma reação ao muco nasal aparente, frequente em Amanda. Nas demais situações não se identificou uma causa física evidente. 


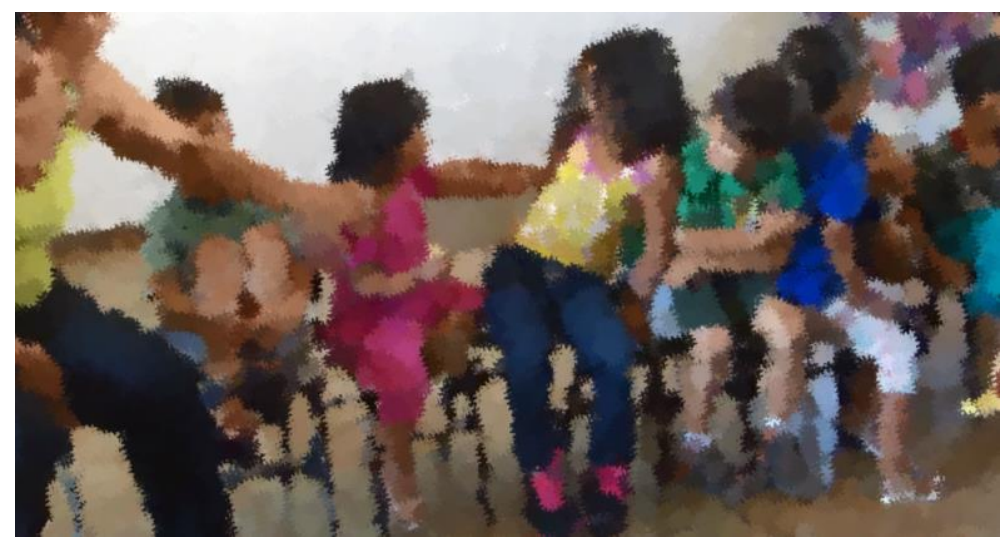

Figura 39. Amanda busca o contato físico com Letícia, mas ela retraise na cadeira e chama pela educadora, solicitando que tire Amanda de perto dela.

Embora as interações entre a criança pivô e os adultos não seja foco deste estudo, é relevante mencionar que o contato físico no estudo de caso Amanda aparece de forma muito evidente junto ao adulto. Acredita-se que isso ocorra em decorrência das educadoras estarem tempo integral com essa criança e em muitas vezes limitarem as interações de pares. Nos momentos em que esse contato físico acontece e é permitido ser desenvolvido, observa-se um repertório rico de gestos e conteúdo (ver figura 40). Junto ao professor, o contato físico não é interrompido, como frequentemente é com os pares; o professor está no controle do tempo e do contexto desse contato.

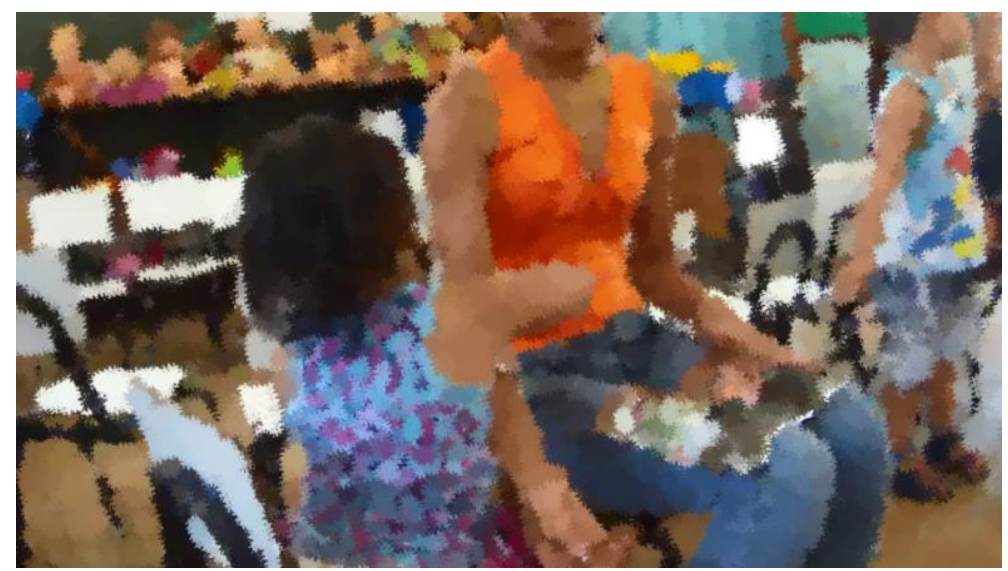

Figura 40. Amanda coloca 'pulseira' de massinha no braço da professora e pinta-o com giz de cera, utilizando o corpo do adulto como material para a atividade lúdica.

Por fim, embora o resultado quantitativo dos contatos físicos de Amanda não evidencie maior incidência de iniciativas de contatos por parte dos pares no espaço do pátio (como nos casos Inácio e Ivan), a partir da análise dos 502 episódios de contatos físicos, se destaca enquanto especificidade do caso de Amanda o uso do contato físico para chamar atenção do colega em meio as atividades livres (59\% do total de contatos físicos), que aconteceram principalmente no espaço do pátio. Assim, 
entende-se que, para Amanda, o pátio tenha sido um espaço em que foi a ela permitido maior liberdade para buscar os pares e estabelecer com eles contatos físicos. Para ilustrar, se apresenta o episódio de interação abaixo.

\section{Amanda em: "Olha pra mim, brinca comigo!"}

\section{Data: 10 de setembro de 2014, gravação n.2 aos 3'26'}

Contexto da cena: As crianças de três anos de diferentes salas de aula estão brincando no pátio da escola (aproximadamente 62 crianças). Usualmente, este é o momento em que as crianças têm condições de brincar com outras crianças que não pertençam diretamente ao seu grupo de idade. Amanda permanece brincando com o seu grupo de sala, apesar de ser incentivada a explorar outras possibilidades.

Descrição da cena: Amanda se aproxima da colega Raissa, senta-se a sua frente, toca sua perna e pega uma das bonecas com as quais Raissa está brincando e que se encontra no chão. Raissa continua brincando com sua boneca. Amanda toca-lhe a perna novamente, segura a boneca imitando os movimentos da colega. Raissa não muda o foco de atenção e continua a brincar com sua própria boneca. Amanda então tenta pela segunda vez contato com a outra criança, pegando uma boneca para si da mão da colega e aproximando-se da colega com a boneca nas mãos. Raissa olha para Amanda e pega a boneca que está no chão e volta a brincar. Amanda posiciona a boneca de forma semelhante à de Raissa e emite alguns sons (incompreensíveis), ao mesmo tempo em que imita os movimentos da colega. Raíssa permanece com o mesmo comportamento anterior, sem retribuir o contato com Amanda, continuando a brincar com sua própria boneca. Amanda levanta-se, balança as mãos na frente da colega e coloca a boneca nos braços. Raissa levanta os olhos em direção a Amanda, e ela então balança os braços lado a lado (como se estivesse ninando a boneca). Raissa olha para o que a colega está fazendo e retorna para sua própria brincadeira. Amanda pega então a boneca pelos braços abre e fecha-lhe os braços conduzindo a boneca no ar (como se a boneca estivesse voando). Amanda caminha, dessa vez em torno do espaço em que as crianças estão brincando e, de tempos em tempos, olha para Raissa. Amanda verbaliza novos sons, incompreensiveis. Raissa olha para Amanda brevemente e retorna a sua atividade anterior (brincando com sua própria boneca). Amanda novamente se aproxima de Raissa, posiciona-se na frente da colega e pega nas suas mãos, desta vez Amanda posiciona a boneca logo abaixo dos olhos de Raissa e repete os movimentos de abrir e fechar os braços da boneca. Raissa olha para Amanda. Após alguns segundos, Raissa volta a brincar sozinha. Amanda fica onde está e observa o que a colega está fazendo por mais um momento. Posteriormente, dirige-se a outro grupo de crianças. 


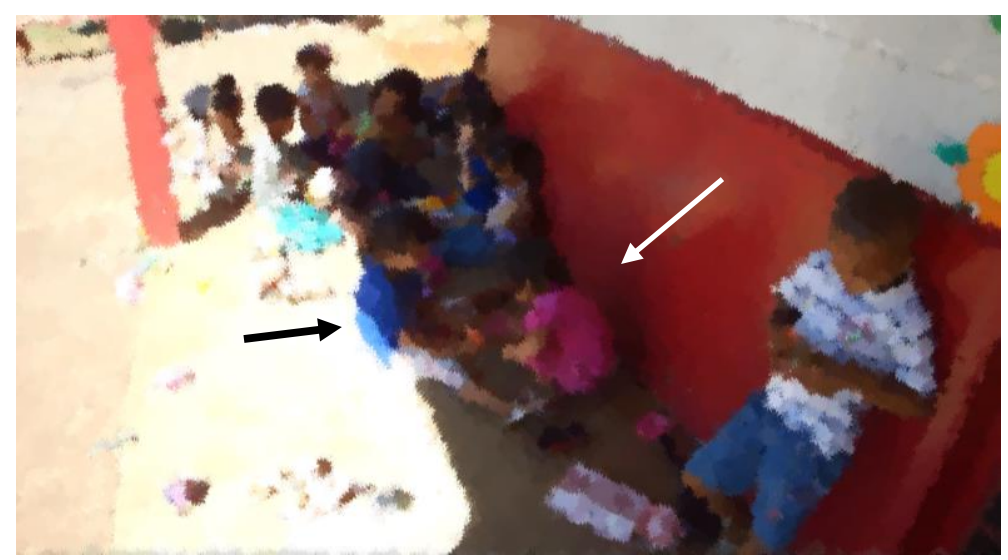

Figura 41. Amanda (flecha branca) aproxima-se e toca a perna de Raissa (flecha preta) pela primeira vez.

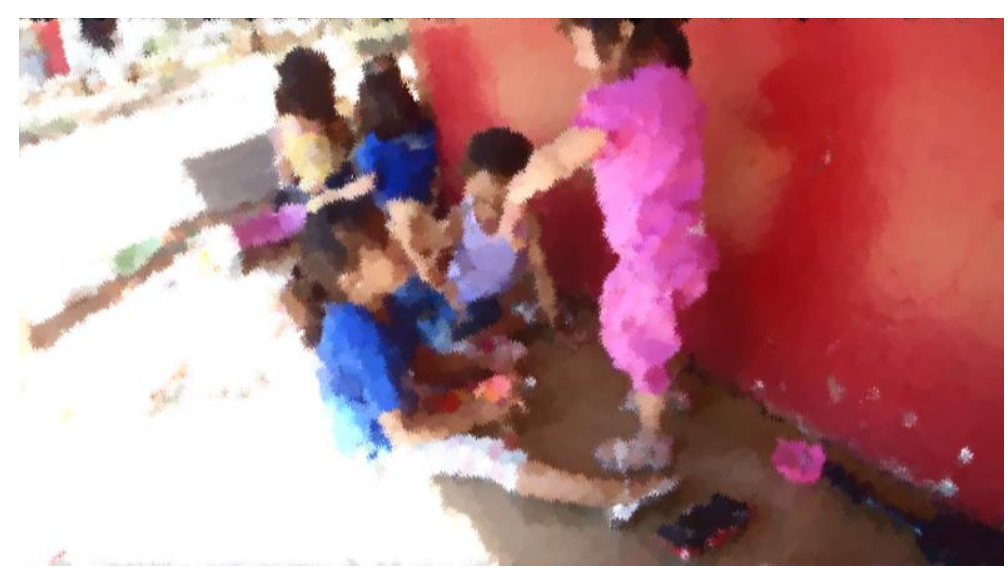

Figura 42. Amanda emite sons e faz gestos na frente de Raissa.

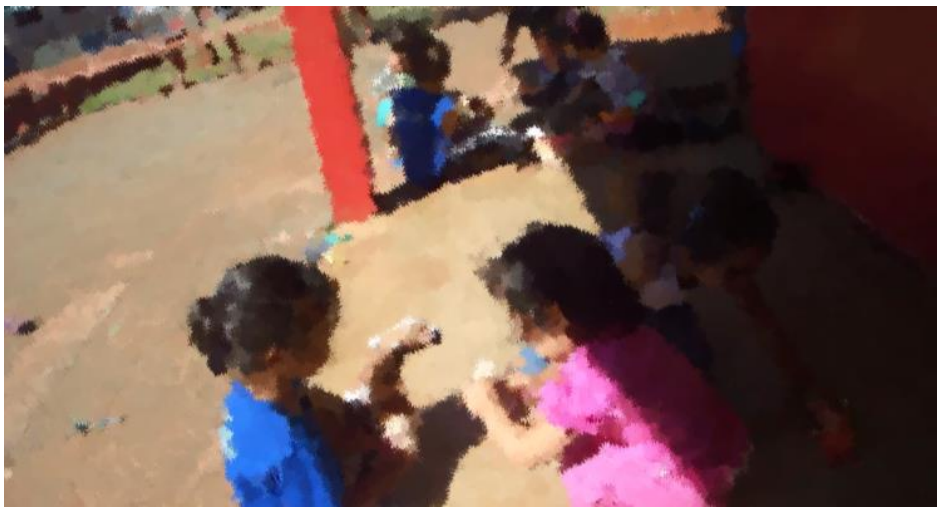

Figure 43. Amanda, aproximando-se de Raissa, após segurar seu braço, mostra a boneca para a colega.

O episódio "Olha pra mim, brinca comigo!", explicita como o contato físico dentro do estudo de caso Amanda tem o papel de focalizar a ação do par para uma possível atividade conjunta. Da mesma forma que Inácio, Amanda busca o contato com o par para a realização de uma atividade. Se no episódio de Inácio o movimento era adentrar uma atividade em curso, aqui o movimento é no sentido de construir algo coletivamente entre Raissa e Amanda. O contato físico vem acompanhado 
de outros elementos, tais como gestos e vocalizações, explicitando que Amanda apresenta diferentes estratégias no seu repertório comunicativo.

Contudo, o contato físico neste episódio não é recíproco e a atenção conjunta advinda das iniciativas de Amanda não se sustentam para o estabelecimento de uma atividade compartilhada. Esse dado revela que o contato físico por si e em si, mesmo que contínuo e contextualizado, talvez não seja o elemento que garanta regulações e corregulações de comportamento que impactem no fazer conjunto. O contato físico precisa desencadear processos de regulação e corregulacao para que a interação entre os pares crie campo para as aprendizagens.

Ao mesmo tempo, é importante ressaltar que não foi identificado nenhum comportamento que sustentaria uma hipótese de rejeição do contato em decorrência da deficiência intelectual, como nas situações descritas em Odom, Brown, Schwartz, Zencher e Sandall (2002). De fato, a colega Raissa brinca sozinha durante todo o tempo, sem o interesse por qualquer que seja o par.

\subsubsection{Reflexões sobre os resultados na fase I: o contato físico entre as crianças}

Os resultados das análises realizadas nesta fase I, evidenciaram três aspectos relevantes sobre a relação entre o espaçolatividade e a incidência de interações e o papel do contato físico na interação de pares: (1) a configuração do espaçolatividade pode interferir na quantidade de contatos físicos nas interações de pares, sendo o ritmo das atividades e a presença (ou ausência) do adulto um fator que influencia nas iniciativas da interação; (2) os contatos físicos se configuram por meio de diferentes comportamentos/gestos e em meio a diversas situações, representando as distintas, ambíguas e complementares formas de estabelecer contato com o outro; e, (3) há reciprocidade na busca por interação, ou seja, mesmo em diferentes quantidades e circunscritos em contextos distintos, tanto a criança com deficiência intelectual, quanto seus pares iniciam processos de interação com contato físico.

Especificamente em relação aos contextos da ECE, estudos anteriores (Vuorisalo et. al, 2015, Rutanen et al, 2014; Rutanen, 2012; Raittila, 2012; Tudge, 2008) apontam que os espaços institucionais podem ser analisados por sua estrutura e organização, implicando em um olhar que considera as ações e dinâmicas estabelecidas por pessoas nas atividades da rotina institucional enquanto um elemento importante de análise. Por essa perspetiva, os valores, as crenças, as preferências, as regras e as ideologias desempenham um papel ativo na retenção e estruturação de recursos desse espaço social, circunscrevendo as relações individuais e/ou de grupo (Carvalho \& Pedrosa, 2004). Mais do que a infraestrutura em que as práticas ocorrem, o espaço é considerado como as manifestações de conceitos de um sistema educacional, sendo parcialmente incorporado pelo currículo da instituição e as práticas pedagógicas propostas. O espaço está intimamente relacionado 
ao currículo e à compreensão do professor de como a escola, o processo de aprendizagem e as práticas devem ocorrer (Vieira, 2015). Portanto, o espaço está relacionado aos processos de fazer sentido, o que envolve negociações entre instituição, professores e crianças em um tempo e contexto específicos.

Neste sentido, os resultados mostram as diferentes quantidades e formas de contato físico nos distintos tipos de espaços (e.g., sala de aula, teatro, pátio) em cada um dos estudos de caso e são entendidos enquanto manifestação da vida institucional, que regula, autoriza, propicia, restringe ou limita os contatos físicos e, consequentemente, as interações de pares, sem necessariamente estar a todo tempo consciente desse processo. A presença das educadoras\monitoras em tempo integral (caso Ivan e Amanda principalmente) aparece como fator limitante dos contatos físicos das crianças ao invés de estimular a interação, conforme apontado por estudos na área (Giangreco \& Doyle, 2002; Logan, 2006;), suscitando a reflexão sobre a forma como se tem entendido que o processo de inclusão escolar de crianças com deficiência intelectual deva ser feito em contextos regulares de ensino.

Os tipos de atividade realizadas na sala de aula não interferiram no quantitativo de interações para Inácio e Ivan, mas foram um fator que se mostrou relevante para Amanda. Unanimemente, o pátio parece se apresentar enquanto o espaço que mais possibilita acesso dos pares a criança pivô, seja pela dinamicidade das atividades que são construídas neste contexto, pela ausência do adulto de forma constante ou ainda, pela possibilidade da própria criança pivô de se colocar mais próxima de seus colegas, onde o contato é favorecido.

A análise dos contatos físicos, especialmente através do olhar mais atento às dinâmicas nos episódios de interação, propiciou também a evidenciação da individualidade na forma como as crianças vivenciam as interações com os pares nos diferentes contextos institucionais, chamando-se a atenção para as diferentes formas com que cada criança lidou com os contatos ou 'não contatos'. Apesar das tentativas de aproximação feitas por Amanda e Inácio e as constantes respostas negativas advindas dos meios em que cada criança se encontrava, a forma de lidar com a resposta negativa ao final do processo foi distinta. No caso de Amanda, diferente de Inácio, o episódio de interação não termina com a criança observando a brincadeira das colegas sentada na cadeira, mas sim com Amanda dirigindo-se a outro grupo de crianças. Essas devem ser particularidades da própria constituição do sujeito, as quais se relacionam com suas vivências anteriores e seu próprio processo de percepção do mundo e dos outros.

Tais particularidades são aqui analisadas a partir das contribuições da própria Rede de Significações (Rossetti-Ferreira, Amorim, Silva \& Carvalho, 2004), que permite uma reflexão dentro da complexidade do fenômeno do desenvolvimento humano para entender a negação, o conflito e a contraposição, não enquanto elementos puramente antagônicos, mas também complementares. Os 
contatos físicos aceitos e compartilhados, que em diversas situações permitiram a continuidade da interação construindo um fazer conjunto, ou o não-contato, que mudam o curso motivacional e em alguns casos também das ações da criança, constituíram os sujeitos (se julga pertinente destacar que essa constituição não diz respeito exclusivamente a criança pivô). É, segundo Rossetti-Ferreira, Amorim e Silva (2004), a heterogeneidade de situações e possibilidade na interação com também heterogêneos pares (seres humanos) que tornam a pessoa múltipla e o seu percurso de desenvolvimento complexo e único.

Ainda sobre as representações do contato físico, reflete-se, a partir dos resultados da fase I, a sua importância enquanto manifestação do corpo e na sua corporeidade, a comunicação. A corporeidade permite que o movimento do corpo carregue sentido, o que significa "abandonar a ideia do corpo como um objeto do mundo ou simples veículo de expressão de um pensamento puro, solipsista e interior" (Furlan, 2004, p.54) e encará-lo enquanto ponto de partida para processos de compartilhamento de significado. Ao olhar-se para os dados sob esse prisma identifica-se que, em todos os casos, os contatos físicos permitiram a expressão de ideias, por exemplo, no episódio “ $E u$ também quero brincar" do caso Inácio os contatos físicos constroem uma ideia de pedir permissão para entrar em um grupo e participar de uma atividade. Ideias que em determinadas situações foram compartilhadas e negadas, compartilhadas e aceitas, ou mesmo não compartilhadas (e.g., episódio "entre tapas e beijos" caso Ivan).

O contato físico esteve presente para os três casos ao longo de todo o ano letivo, manifestouse em todos os espaços e contextos em que as crianças estiveram dentro do ambiente escolar e foi identificado não só partindo das crianças pivô, mas também dos pares de idade. Esses dados indicam perspectivas opostas à pesquisas anteriores que sustentam a tese de que a criança com déficit intelectual é preterida dentro do grupo (Buysse, Goldman \& Skinner, 2002; Gulranick \& Groom, 1988; Gulranick, Neville, Hammond \& Connor, 2007) e oferece evidências para a discussão de que existe reciprocidade no interesse dos pares no processo de interação com a criança pivô nos contextos institucionais de educação infantil, mostrando que não há um movimento natural de isolamento da criança com déficit intelectual em contextos regulares de ensino e cuidado.

Segundo Trevarthen e Aitken (2001), as crianças buscam na relação com o par o pertencimento à comunidade, buscam ser reconhecidas como alguém que sabe algo e que pertence ao mundo de outras pessoas que compartilham um entendimento. Os contatos físicos identificados na análise dos dados indicam um movimento similar também para as crianças com desenvolvimento atípico, neste caso crianças com déficit intelectual. Os dados também mostram que a busca pelo outro é iniciada por todos os membros dessa pequena comunidade, corroborando com a defesa de que toda 
e qualquer criança é ativa na construção do seu desenvolvimento e partícipe no desenvolvimento do outro.

\subsubsection{Resultados referentes à fase II - Mapeamento e microgenética das regulações de comportamento.}

Como explicitado na metodologia, a análise na fase II consistiu em novo mapeamento dos processos de interação, dessa vez com enfoque na identificação da regulação e, possivelmente, corregulações de comportamento (Carvalho, Império-Hamburger \& Pedrosa, 1996).

Inicialmente, apresentam-se os dados quantitativos referentes às ocorrências de episódios de regulações de comportamento. Em seguida, caso a caso, serão apresentados episódios que explicitam diferentes nuances de como esse processo ocorreu, buscando evidenciar possíveis relações entre as regulações de comportamento e a construção de Zonas de Desenvolvimento Proximal na interação dos pares.

Abaixo, na tabela 11, encontram-se os dados quantitativos de situações de regulação de comportamentos dos três casos - Inácio, Ivan e Amanda -, em relação às quais identificou-se a regulação de comportamento, acompanhada ou não pelo compartilhamento de objetos ou por atenção conjunta.

Tabela 11. - Ocorrência de episódios de interação de acordo com a análise da regulação de comportamento na fase II.

\begin{tabular}{lccc}
\hline Caso & $\begin{array}{l}\text { Regulação de comportamento } \\
\text { sem compartilhamento de } \\
\text { objetos ou atenção conjunta. }\end{array}$ & $\begin{array}{l}\text { Regulação de comportamento } \\
\text { acompanhado de compartilhamento } \\
\text { de objetos ou atenção conjunta }\end{array}$ & Total \\
\hline Inácio & $44(26 \%)$ & $148(74 \%)$ & 192 \\
Ivan & $22(8,90 \%)$ & $225(91,10 \%)$ & 247 \\
Amanda & $07(4,25 \%)$ & $165(95,75 \%)$ & 172 \\
\hline
\end{tabular}

Nos três casos analisados, verifica-se que há uma expressiva diferença entre a incidência de regulações de comportamento em situações sem e com o compartilhamento de objetos ou atenção conjunta. A maior incidência de regulações com compartilhamento de objetos ou atenção conjunta corrobora com resultados e discussões de estudos anteriores que consideram a atenção conjunta como um dos elementos centrais constituintes na interação humana (Aquino \& Salomão, 2009; Bosa, 2002; Butterworth, 1995), justificando, assim, a sua maior ocorrência no total das interações. Entretanto, julga-se relevante destacar que os resultados também revelam a existência de regulações sem compartilhamento de objetos ou atenção conjunta nesses contextos investigados. Tal situação 
corrobora a afirmação de que a interação acontece mesmo na ausência da consciência do sujeito sobre sua interferência direta no campo interacional (Amorim 2008; Carvalho, Império-Hamburger \& Pedrosa; 1996; Ferreira, 2012; Moura, 2012; Pedrosa \& Carvalho, 1995).

Para ilustrar tais situações, apresentam-se abaixo dois episódios: o primeiro destaca a regulação de comportamento com compartilhamento de objeto e atenção conjunta; e o segundo um episódio de regulação de comportamento sem compartilhamento de objeto ou atenção conjunta.

\section{Ivan em: "Enquanto a gente espera"}

\section{Data: 29 de julho de 2014, registro n.1 aos 3'10'}

Contexto: As crianças (Carla, Luis e Ivan) estão sentadas à mesa, aguardando a entrega dos materiais (lápis e folha com a atividade) pelos colegas 'ajudantes' da professora (Otávio e Manuela). No contexto dessa cena, a professora propôs para as crianças uma atividade de reconhecimento das letras e solicitou-lhes que escolhessem um lugar para se sentarem e esperassem pela entrega dos materiais pelos colegas.

Descrição da cena: Carla, Ivan e Luis (ordem no sentido horário) sentam-se à mesa, à espera do material que está sendo entregue por Otávio. Ivan aponta para o quadro de nomes dos alunos da sala e Carla verbaliza algo incompreensível. Otávio se aproxima e entrega um lápis preto para Luis, que imediatamente bate com o lápis na mesa, emitindo um som estridente (pá, pá, pá). Carla e Ivan olham para Luis. Otávio entrega um lápis para Carla, que imediatamente também o bate na mesa, produzindo o mesmo som (pá, pá, pá, pá). Otávio estica a mão cruzando a mesa em direção a Ivan e entrega-lhe um lápis. Da mesma forma que Carla e Luis, Ivan bate com o lápis na mesa, produzindo o mesmo som (pá, pá, pá, pá). As três crianças batem com o lápis na mesa ao mesmo tempo por alguns segundos, produzindo um som alto e estridente. A monitora da turma vem à mesa e se senta entre Carla e Ivan. Ela procura algo, dentro de uma caixa cheia de letras móveis. Carla recua na cadeira em direção contrária à das demais crianças, coloca a mão esquerda no ouvido esquerdo e faz uma cara de repúdio (franze os olhos e contorce a boca e o nariz), enquanto segura o lápis com a mão direita. Carla olha para Ivan e aponta seu lápis na direção do dele. Carla usa a ponta do seu lápis para tocar no lápis de Ivan e em um movimento de x faz com que ambos os lápis se cruzem (lembrando uma luta de espada). Ivan sorri, Carla sorri. Ivan imediatamente se engaja no mesmo movimento e eles cruzam os lápis algumas vezes. Ivan vira-se em direção a Luis, aponta seu lápis para o dele e também faz um movimento de x cruzando os lápis. Ivan sorri. Ivan e Luis balançam os lápis algumas vezes ora cruzando-os, reproduzindo o mesmo movimento de x anterior. Ivan muda a forma de segurar o lápis, trazendo-o para perto de si e segurando-o com as duas mãos (lembrando uma arma de fogo), aponta para a direção da estante, fecha um dos olhos e balbucia um som 'tchi, tchi'. Luis passa então a segurar o seu próprio lápis da mesma forma, também aponta para a estante, franze os olhos e verbaliza 'pum, pum, pum'. Ivan e Luis apontam os lápis entre si, verbalizam 'pum, pum' e continuam por alguns segundos. 


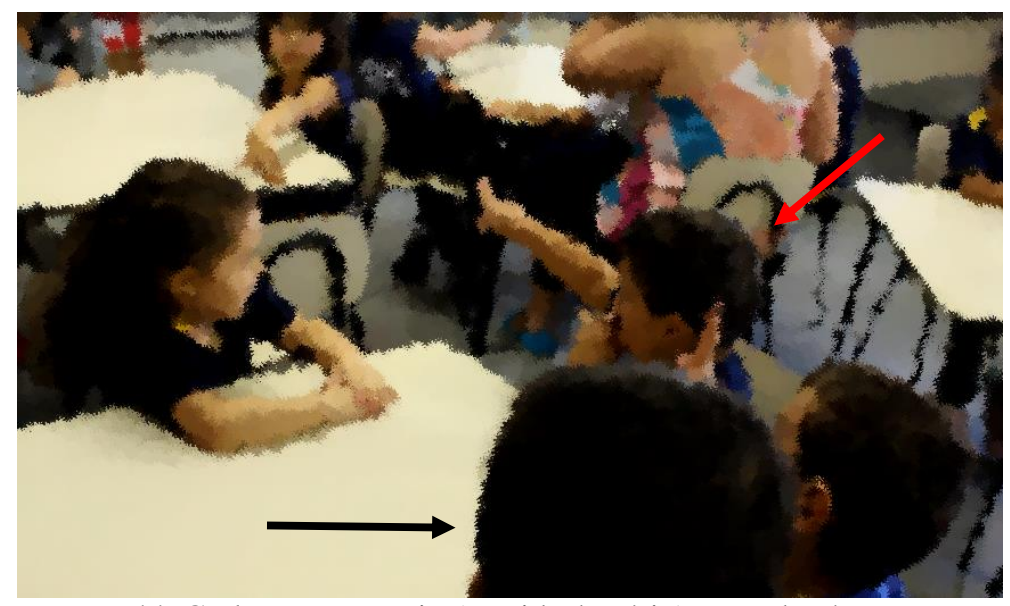

Figura 44. Carla, Ivan e Luis (sentido horário) sentados à mesa no momento de espera pela entrega dos materiais. Ivan (flecha vermelha) gesticula, apontando para o quadro de nomes da turma (verbalizações são incompreensíveis) enquanto Otávio (flecha preta) entrega os lápis.

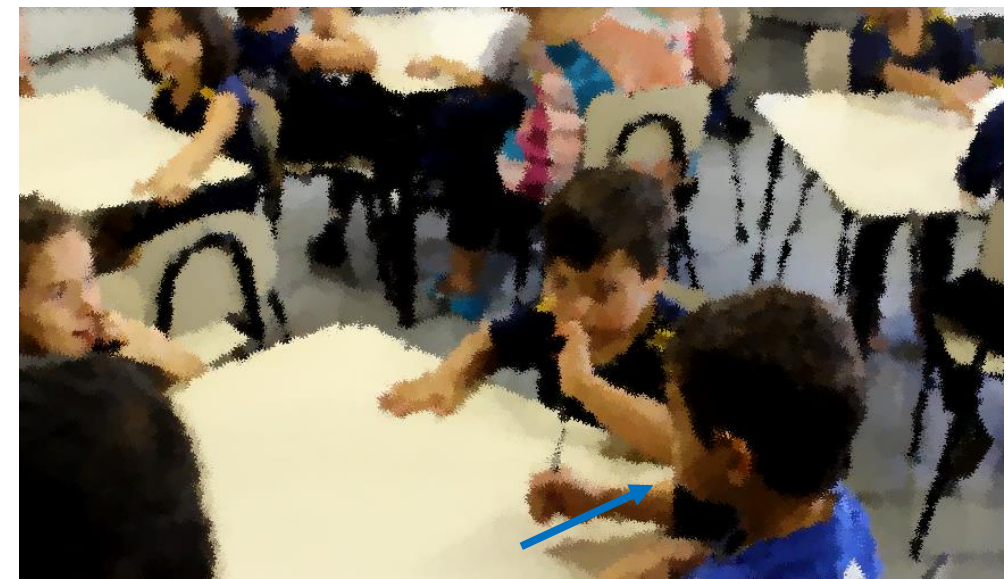

Figura 45. Luis (flecha azul) bate com o lápis na mesa.

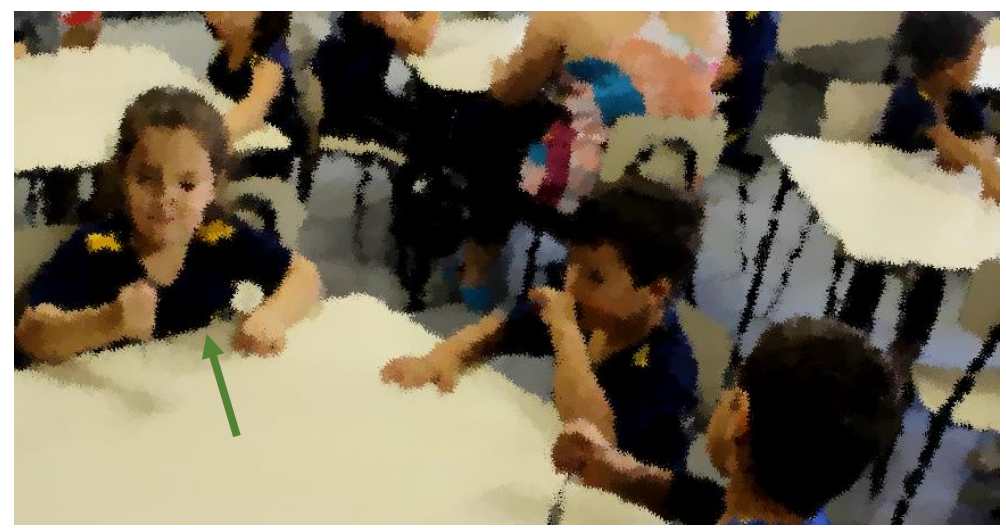

Figura 46. Carla (flecha verde) bate com o lápis na mesa. Luis bate com lápis na mesa e Ivan olha para Carla. 


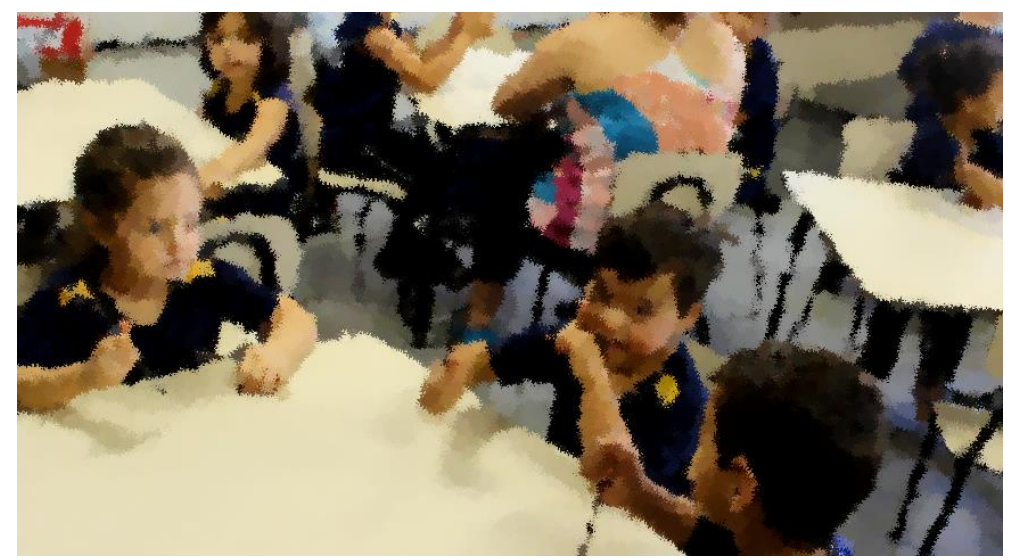

Figura 47. Ivan bate com o lápis na mesa, ao mesmo tempo em que olha para Luis.

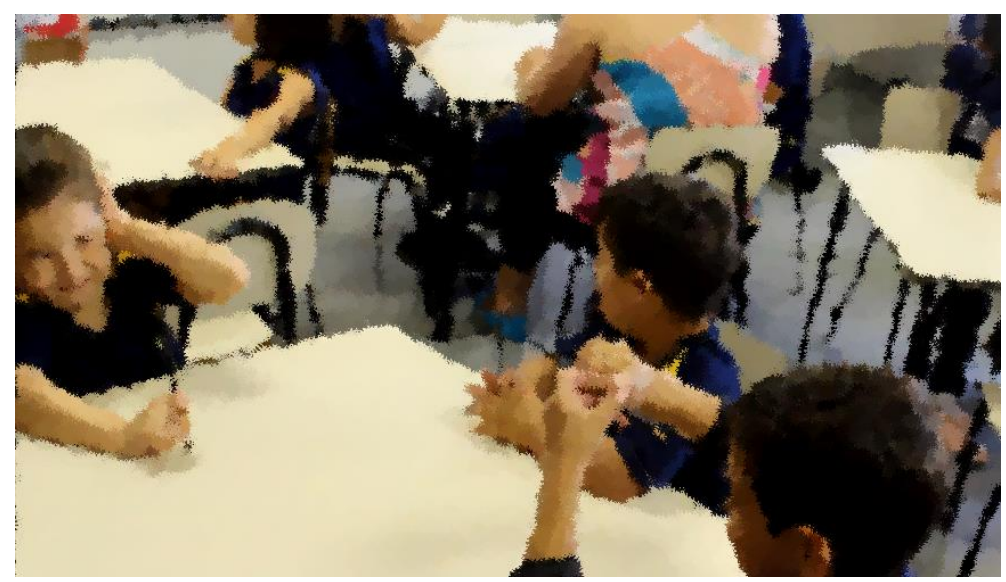

Figura 48. Carla coloca a mão no ouvido e recua na cadeira em direção contrária à de Ivan e Luis que continuam a bater com o lápis na mesa.

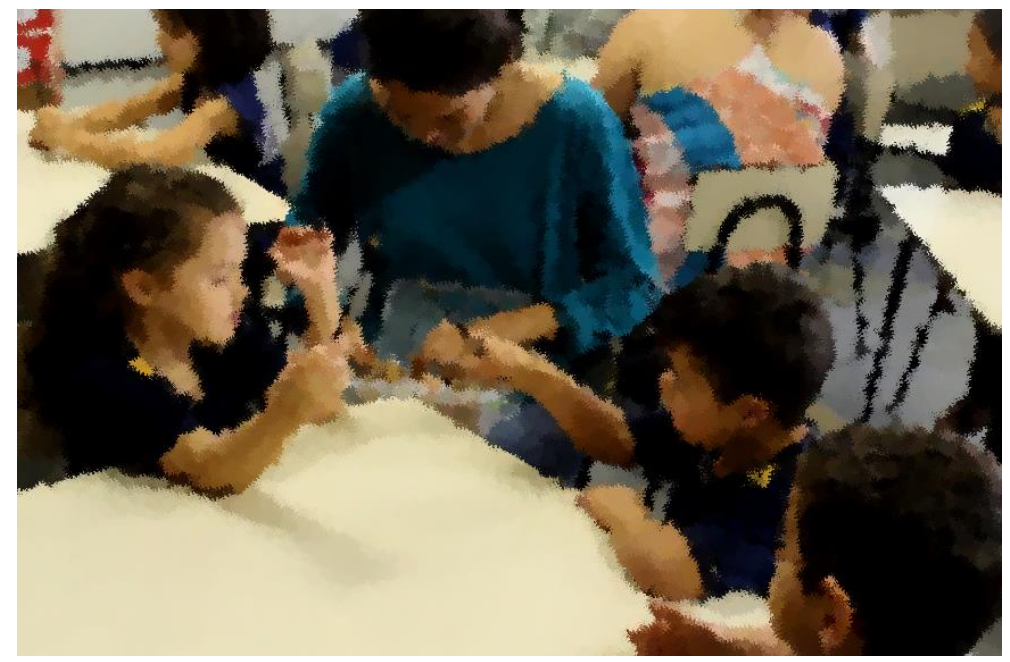

Fugira 49. Carla e Ivan cruzando seus lápis (movimento de luta de espada). 


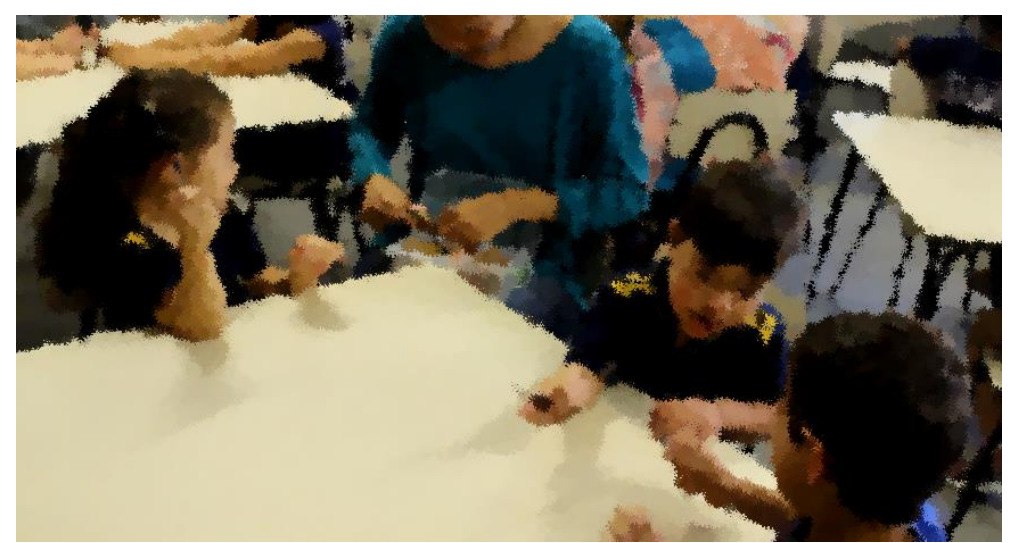

Figura 50. Ivan cruza seu lápis com o de Luis.

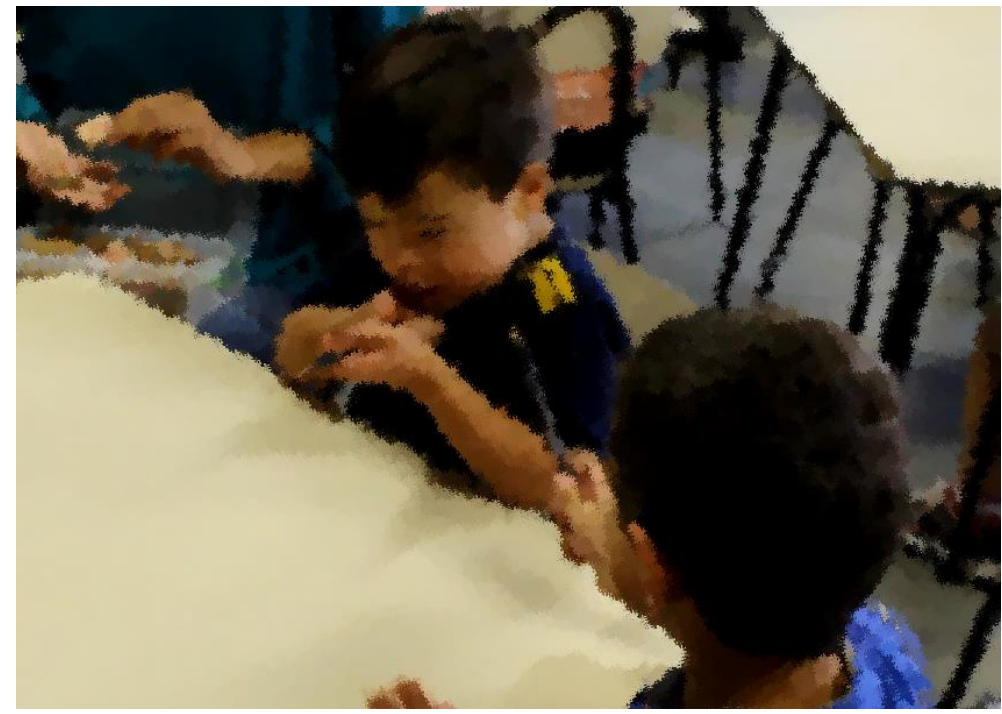

Figura 51. Ivan segura seu lápis com as duas mãos, aponta-o e verbaliza tchi, tchi (representando uma arma de fogo).

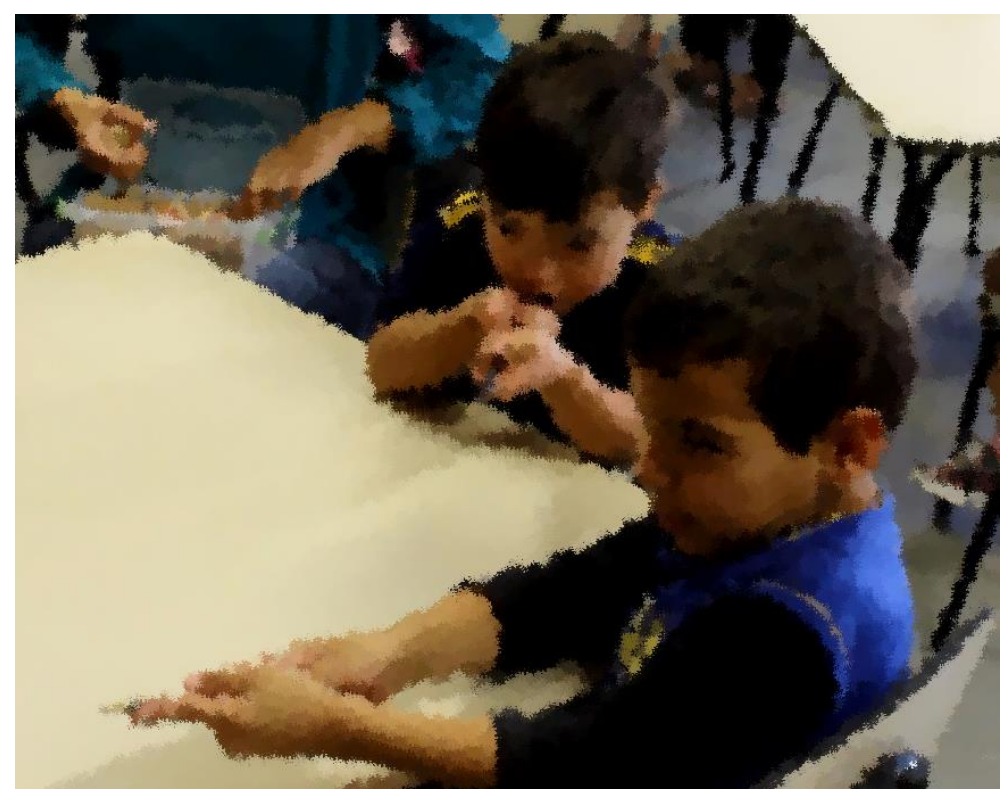

Figura 52. Ivan e Luis em atividade de faz de conta, utilizando o lápis como representação de uma arma. 
A análise da regulação de comportamento (Carvalho, Império-Hamburger \& Pedrosa, 1996) - enquanto situação em que para se compreender os movimentos de um membro de um grupo (neste caso, Ivan) - que requer que se considere os comportamentos dos demais componentes desse grupo (Carla, Luis e Otávio), é ilustrada nesse episódio a partir da trajetória dos movimentos das crianças desse campo social. Nesse processo, chama-se atenção para: (1) as diferentes direções do trânsito de informações (e.g., Luis-Carla \Luis-Carla-Ivan \Carla-Ivan \Ivan-Luis \Luis- Ivan) no potencial de regulações de comportamento que definem a interação; e, (2) para repetição e inovação como elementos básicos da cultura de pares de crianças pequenas (Corsaro \& Molinari, 1990; Lucena 2010).

$\mathrm{Na}$ análise da interação particular desse episódio, as regulações e corregulações de comportamento construíram um momento de atividade conjunta (brincadeira particular desse grupo) que (re)significa o momento da espera (institucionalizado e caracterizado dessa forma pela professora naquele contexto da sala de aula). Essa construção tem início na imitação de um comportamento com base no uso do objeto (Ivan que imita Carla que imitou Luis batendo o lápis na mesa), que se desenvolve para uma atividade de faz de conta compartilhada (e.g., Carla e Ivan na "luta de espadas"; e, posteriormente, Ivan e Luis na luta de espada; finalmente, depois, usando o lápis como arma de fogo). Neste processo, a atenção conjunta (Tomasello, 1995) principia e sustenta a manutenção dos elementos (i.e., trocas de olhares, expressões faciais e corporais, gestos, verbalizações e movimento) que compõem as trocas de informação no campo interativo que, por sua vez, estruturam a forma como as crianças vão reconstruindo significado ao uso do objeto (lápis) a partir da ação do outro e de elementos culturais, materializando o compartilhamento dos significados.

No que se refere ao conteúdo do processo regulatório (i.e., o que está acontecendo ao longo das regulações e corregulações), sob o ponto de vista da análise dos comportamentos de Ivan, identifica-se que no processo de transição entre as ações de imitação (e.g., Ivan imitando o comportamento de Luis e Carla ao bater o lápis na mesa, Ivan imitando a dinâmica da luta de espadas iniciada por Carla) para a construção do faz de conta (e.g., Ivan modificando o uso do lápis no faz de conta, de espada para a arma de fogo), houve uma mudança nos comportamentos dessa criança (e.g., da ação de imitar para a ação de criarlpropor). Os pares neste contexto, participam oferecendo elementos que subsidiaram a construção desse processo (e.g., Luis chama atenção para possibilidades do uso do lápis para produção de som; Carla usa o lápis como espada, já transformando seu uso no contexto); a presença, a atenção e a reação específica imediata dos três membros presentes nesse campo social, afeta e modela o tipo de performance (combinação entre gestos, expressões e ação) em que eles estão envolvidos, evidenciando o engajamento intersubjetivo e as possibilidades 
(affordances) do ambiente, conforme descrito por Rucinska (2014) e identificado em estudos anteriores (Ferreira, Mäkinen \& Amorim, 2016).

Para além disso, mesmo que o ato de Ivan de representar uma arma de fogo com o lápis possa estar relacionado a vivências anteriores (e.g., imitação sem modelo (Wallon, 2008), cabe argumentar que, no contexto interacional deste episódio, a trajetória das regulações mostra a transformação das ações de Ivan dentro do sentido da atividade que estava sendo construída (brincadeira de faz de conta). Dessa forma, entende-se que na presença e ação do par, a criança (aqui com déficit intelectual) foi impulsionada a realizar atividades que sozinha (talvez) não o fizesse. Nessa construção, criou-se um significado particular para aquele momento de espera pelo material, em um movimento próprio da cultura infantil. Embora possa contrariar ou diferir da cultura institucional, conforme descrito em situações semelhantes em outros estudos (Corsaro, 2005; Rutanen, 2009), indica a participação da criança pivô no processo.

Complementando a ilustração sobre a regulação de comportamento, segue abaixo o segundo episódio onde a regulação ocorre sem o compartilhamento de objeto ou atenção conjunta.

\section{Inácio em: "O que tem atrás desse muro?"}

\section{Data: 15 de abril de 2014, registro n.2 aos 5'50'}

Contexto: Neste episódio, Inácio está junto com a sua turma, voltando para sala de aula após o horário de lanche. Neste momento, várias salas de aula se misturam, pois, os horários de lanche ocorrem simultaneamente para todas as turmas.

Descrição da cena: Ao adentrar o corredor da rampa, Inácio, que segura a mão da monitora de sala, olha para um menino, poucos metros à sua frente. Esse está colocando os pés no corrimão da rampa, impulsionando-se para cima e pendurando-se na mureta que divide o espaço da rampa e o pátio escolar. Esse aluno, que pertence a outra sala de aula, eleva-se, conseguindo olhar para o outro lado do muro. Imediatamente, ele desce do corrimão. Sem olhar para trás, a criança segue em frente andando em direção ao topo da rampa. Não há qualquer contato visual entre ele e Inácio. Inácio, que caminhava acompanhado da monitora, solta a sua mão da dela e vira-se em direção ao corrimão da rampa; ao chegar lá, ele vira o rosto e olha ao seu redor. A monitora está olhando para outra direção. Inácio retoma sua posição em relação ao corrimão, coloca seu pé direito no corrimão e tenta impulsionar-se para cima, no movimento de escalar o muro. Inácio consegue tirar os dois pés do chão, sem subir de fato no corrimão. Porém, nessa posição, ele não tem a altura para olhar por cima do muro. A monitora identifica a ação de Inácio e vai em sua direção, interrompendo-o. 


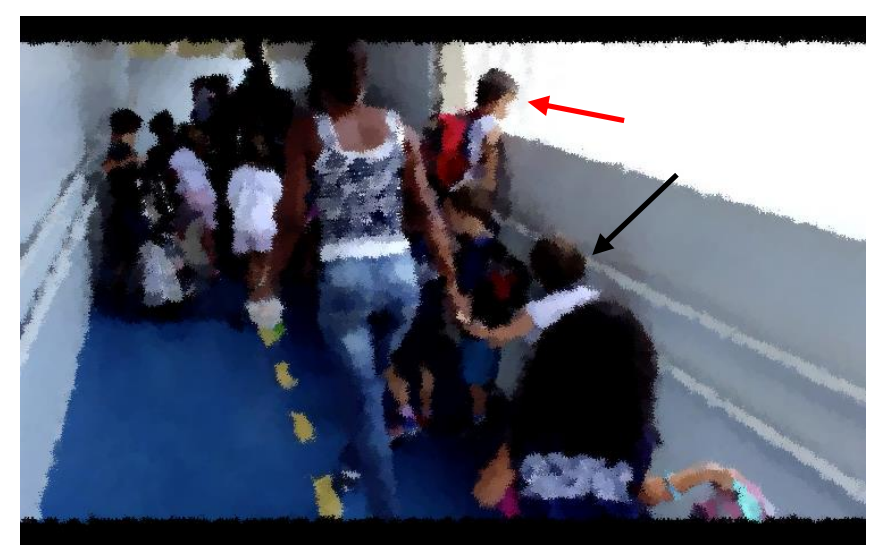

Figura 53 - Inácio (flecha preta) olhando o colega (flecha vermelha) pendurar-se no corrimão da rampa.

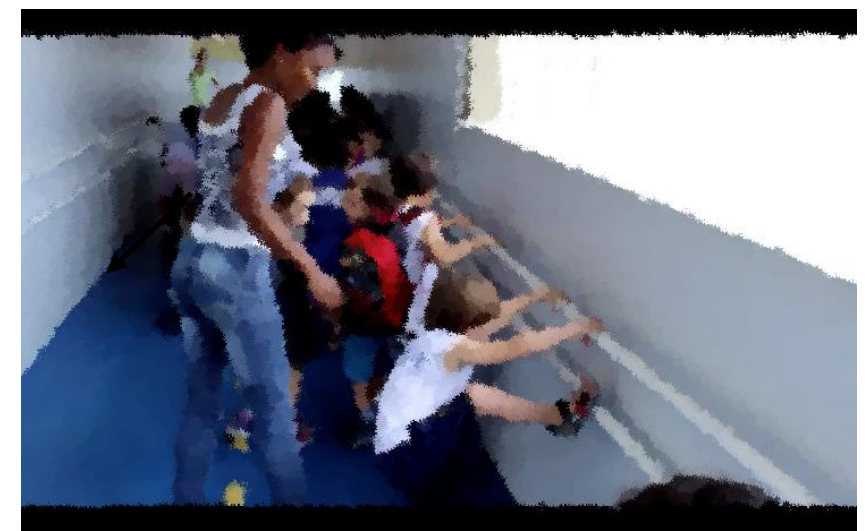

Figura 54 - Inácio pendurando-se no corrimão da rampa.

Segundo Carvalho, Império-Hamburger e Pedrosa (1996) “a ação individual não se opõe ao campo social, mas pertence a ele, mesmo quando é a ação do outro que revela essa pertinência” (p. 7). Neste episódio de interação, a regulação de comportamento é evidenciada pela ação de Inácio tendo levado em conta as ações de um membro específico do campo social (criança de outra turma). Embora a criança à frente de Inácio não faça parte de seu grupo, não tenha estabelecido com ele nenhum contato físico ou visual, não tenha lhe dirigido a palavra, compartilhado objetos ou sequer tenha observado seu olhar atento, ainda assim, os comportamentos dessa criança regulam os de Inácio. Nessa cena, que explicita a imprevisibilidade de atribuições de significado pertencentes ao campo interativo, evidencia também que - na presença do par (mesmo que esse não faça parte do grupo de contato direto) -, a criança (inclusive a com déficit intelectual) é impulsionada a adotar posturasłrealizar movimentos que não faz (fazia) sozinha.

Notas do diário de campo trazem informações complementares para a compreensão da relevância de episódios interacionais como esse no contexto de desenvolvimento de Inácio. 


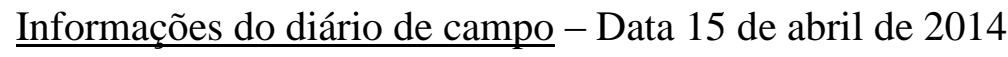

(...) ficamos todos (eu, a professora e a monitora de sala) surpresos hoje com Inácio. Ele se aventurou em algo que, principalmente, a professora jamais imaginava. Ele tentou se pendurar no muro que divide o pátio da escola. Ele sempre foi reconhecido pelos professores e pela mãe como uma criança que pouco se arrisca em movimentos de que não tem domínio para realizar. Estamos tendo desafios na aula de educação física, pois ele tem medo de pular com um pé só. É uma criança que sobe e desce escadas segurando atentamente o corrimão, tem dificuldades de pular e saltar, sente medo daquilo que é desconhecido (papel laminado, fantasias infantis, penduricarias que enfeitam a sala de aula e muitos outros objetos) e que se mantém sempre muito próximo aos adultos quando está em ambiente aberto. (...)

Não é possível identificar a natureza exata da regulação, (o que precisamente faz com que a regulação aconteça), se há algo, a priori, na relação com o sujeito, com a ação em si, ou com o espaço. Contudo, por meio dos comportamentos observáveis, das informações contextuais e dos dados que compõem todo o campo da pesquisa, entende-se que, a partir da imitação, houve uma mudança no comportamento da criança. Tal mudança se refere à posturalatitude de Inácio frente à possibilidade de subir no corrimão da rampa. Ao imitar a ação do par de escalar o corrimão/muro (o que não havia sido registrado anteriormente ao longo da experiência de Inácio na escola), uma habilidade pode começar a ser desenvolvida. Nessa imitação, não se pode supor que Inácio reconheça a possível intenção da outra criança (de observar para além do muro), mas lhe abre espaço para ações que vão além de seu campo imediato.

Para além de tornar explícito o processo de regulação de comportamento sem o compartilhamento de objetos ou atenção conjunta, esse episódio também oferece evidências para se discutir sobre como as regulações de comportamento circunscrevem os papéis sociais do sujeito em seu contexto. Oliveira (2011), ao explicar o conceito de papel nas obras de Vygotsky, afirma que "as relações vividas no drama criam a estrutura da personalidade, e o papel social assumido pela pessoa em uma determinada situação determina a hierarquia das funções mediadoras da sua ação" (p. 57). Dessa forma, quando Inácio age a partir da interação com o par (observa o colega subir no muro e, posteriormente, também passa a escalá-lo), os produtos dessa ação (a escalada), são (re)significados pelos demais membros daquele campo social, implicando em novas possibilidades de interação com essa criança. O papel que Inácio ocupava, de uma criança que tem medo, que tem limitações no uso do próprio corpo e do espaço (cf. diário de campo) se transforma, por exemplo, no papel de uma criança que está tentando novas situações, de uma criança que ousa e que está atenta ao que os outros fazem (diferentes sentidos serão construídos dentre aqueles partícipes do campo social). Assim, as cotidianas, contínuas e muitas vezes, imperceptíveis regulações de comportamento, desempenham parte importante na configuração do conjunto de comportamentos do indivíduo que redefinem seus diferentes papéis sociais dentro do grupo social. 
Cabe neste momento destacar que, no que tangencia a constituição de Zonas de Desenvolvimento Proximal, entende-se que as regulações de comportamento, tanto acompanhadas de compartilhamento de objetos ou atenção conjunta ou ausentes desses, são importantes elementos para se compreender a ação do par no desenvolvimento dessas crianças com déficit intelectual nesses contextos institucionais de educação infantil. Reconhece-se que o conceito de ZPD, enquanto constructo teórico, utilizado por Vygotsky como argumento retórico mediador (Vasconcelos \& Valsiner; 1995) seja, em sua essência, abstrato. Contudo, o elemento constituidor das regulaçõeslcorregulações de comportamento (i.e., a compreensão do comportamento do indivíduo pelo movimentolação do outro ou junto com o outro), conforme apontado no presente trabalho, pode ser um caminho para se estudar a materialização (não como objeto observável, mas como processo em curso) do que o conceito de ZPD abstratamente trata.

Em ambos os episódios apresentados acima, observa-se que a ação do par oferece suporte para que a criança pivô apresente comportamentos que, circunstancialmente, ela não apresentaria sem o par. Tomando como referência para a compreensão do que seja a ZDP, a ideia de que "a pessoa em desenvolvimento transforma, ativamente, a experiência interpessoal numa forma semiótica nova (intrapessoal)" (Vasconcellos \& Valsiner, 1995, p.64), tem-se que considerar que tudo o que acontece ao entorno dessa pessoa (e.g., gestos, falas, movimentos, objetos e etc.) constituindo essa experiência, delimita sua atividade e a guia em um caminho específico de desenvolvimento (Vasconcellos \& Valsiner, 1995). Considera-se ainda que, enquanto a pessoa (neste caso a criança com déficit intelectual) se move ao longo deste caminho (e.g., a brincadeira durante o momento de espera, ou a escalada do corrimão na rampa da escola) ela o (re)elabora de acordo com suas capacidades e interesses. Dentro dessa perspectiva, os elementos provisionados pelos pares (e.g., a focalização em um objeto, a transformação no uso do objeto, os movimentos e etc.) oferecem os indícios necessários para que a criança continue no percurso (e.g., construção da brincadeira), considerando sua própria vivência/experiência, como discute Vygotsky. Assim, residiria na análise dos conteúdos das regulações de comportamento, ao longo do tempo, os indícios para a análise do desenvolvimento.

Com o intuito de aprofundar na discussão sobre as possíveis relações entre as regulações de comportamento e a constituição da ZDP, a seguir, apresentam-se os resultados, caso a caso, explicitando diferentes aspectos da singularidade com a qual as interações foram construídas.

\section{Interação de pares e sua singular constituição: a imitação e o papel do par preferencial.}

Ao se analisar em maior detalhe como as regulações de comportamento ocorreram, os dados revelaram que, para cada um dos participantes, aspectos específicos e distintos marcaram o processo 
constituidor das interações, chamando a atenção para a individualidade e a particularidade com que as interações foram sendo constituídas, mesmo quando compartilhando o mesmo contexto institucional, como no caso de Ivan e Inácio.

Destacando aspectos considerados relevantes, o primeiro ponto diz respeito à diferença no percentual de regulações de comportamento em situações sem compartilhamento de objetos ou atenção conjunta (conforme tabela 11 apresentada na página 110). Nesta situação, os dados mostram que Inácio esteve envolvido em quase três vezes mais situações de regulações que Ivan, e em torno de seis vezes mais do que Amanda.

Aqui, se poderia argumentar que tal resultado advêm das possíveis diferenças no processo de desenvolvimento das habilidades cognitivas das crianças pivô nos três casos. Particularmente, poderia estar relacionado à atenção, apontada por Luria (1973; 1979), como o mecanismo essencial pelo qual a criança, gradativamente, internaliza, seleciona e organiza estímulos e adquire consciência para a ação, a partir do foco de atenção.

Contudo, a partir da perspectiva da complexidade, considerando os múltiplos fatores circunscritores do desenvolvimento humano (Silva, Rossetti-Ferreira \& Carvalho, 2004), buscou-se analisar outros aspectos que possivelmente estariam relacionados a essa situação de regulação do comportamento. Neste processo, identificaram-se dois elementos relevantes: (1) a influência na organização do espaço; e, (2) a influência da ação do adulto neste contexto.

A organização do espaço aparece como elemento circunscritor da interação entre crianças, definindo dinâmicas e a construção de cultura na educação infantil em diversos estudos (Raittila, 2012; Rutanen, 2009; 2014; Rutanen, Costa \& Amorim, 2016). Nos casos aqui apresentados, identificou-se que o tipo de mobiliário e sua disposição configuravam cenários diferentes e que esses contribuíam (ou não) para a troca de informação entre as crianças no campo de interação. Para Inácio e Ivan, as atividades eram realizadas em mesas (acomodação para quatro crianças) ou no chão em grande roda (visibilidade para as ações de todo o grupo). Quando do uso das mesas, essas eram espalhadas por toda a extensão da sala, possibilitando que as crianças circulassem com autonomia entre uma e outra e tivessem contato direto com o que as outras crianças estavam fazendo (figura 55). Quando as atividades eram realizadas no chão, as mesas eram reposicionadas dando maior espaço para que as crianças se organizassem. Essa situação oferecia grande visibilidade, pelas crianças, em relação ao que estava acontecendo na sala de aula e ao que os pares estavam fazendo (i.e., aumento das possibilidades de percepção e do campo de interação).

Na sala de aula da Amanda, por outro lado, as atividades eram realizadas (majoritariamente), no chão, em pequenos grupos (em torno de cinco a sete alunos por grupo) separados em cantos da sala de aula, ou na própria cadeira em que as crianças estavam sentadas (i.e., não tinha mesa. Portanto, 
a atividade era posicionada no colo da criança, como ilustra a figura 56). A separação das crianças em grupos específicos (estipulada pelo adulto) restringia neste contexto a autonomia da criança na escolha de seus pares, bem como limitava o campo de interação. E, a realização das atividades no próprio colo limitava o campo visual das crianças (o foco permanece no âmbito do seu próprio corpo e em direção ao colo e ao chão).

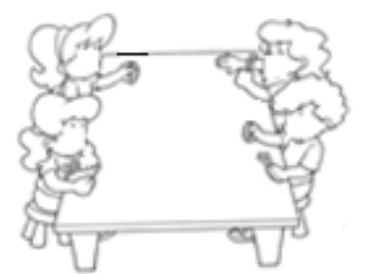

Figura.55 - Ilustração da organização dos alunos no momento de realização de atividades em sala de aula no contexto de Inácio e Ivan

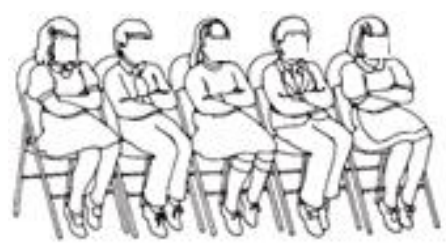

Figura.56- Ilustração da organização dos alunos no momento de realização de atividades no contexto de Amanda

Já com relação a ação do adulto, identificou-se que em 938 minutos (89\%) do tempo total de vídeo-registro (1054 minutos e 30 segundos), Amanda esteve acompanhada por um adulto (educadoras 95,5\%, professora 4,5\%) ${ }^{31}$. Em sala de aula, este adulto estipulou onde Amanda sentaria, definindo o par com quem Amanda compartilharia a atividade (seja ela qual fosse) em $94 \%$ das vezes circunscrevendo intensamente o processo de regulação de comportamento que aconteceria entre as crianças (fosse iniciado por Amanda ou pelo par).

No contexto de Ivan, ele contou com a presença do adulto em 677 (90\%) do tempo total de 759 minutos de registro (monitora 96,76\%, professora 3,24\%). Porém, não houve imposição explicita para o contato com pares específicos, apesar de ter havido em $65 \%$ das vezes, a orientação por parte do adulto na escolha do lugar onde posicionar Ivan para a realização da atividade.

No caso de Inácio, um adulto estava presente em 355 minutos (47\%) do tempo total (monitoras $73 \%$, professora 27\%). Inácio escolhia onde ele sentaria em $91 \%$ das vezes e não foi constatado nenhum momento em que houvesse a imposição do adulto no estabelecimento de quais pares fariam parte da atividade junto com ele.

Em relação a Ivan e a Amanda, Inácio teve, ao longo do ano, menor presença do adulto, havendo maior frequência e melhores condições em termos de liberdade e autonomia de circulação e escolha pelos pares para estabelecer interação. A organização da sala de aula privilegiou o contato visual com um maior número de crianças e suas atividades, aumentando as possibilidades de percepção do espaço e das pessoas nele, constituindo o campo de interação para Inácio. Ivan, embora

\footnotetext{
31 Considerando os 938 minutos (89\%) agora como referência $100 \%$.
} 
tivesse as mesmas condições na organização da sala de aula, contou com a presença mais frequente do adulto em seu dia-a-dia na escola e menor possibilidade de escolha na interação com pares. Tal estrutura está diretamente relacionada à forma pela qual os professores avaliam a demanda pedagógica por educadores (ou monitores) na sala de aula. Aqui ainda cabe destacar que as diferenças na organização do espaço e na atuação dos profissionais junto a criança com déficit intelectual no grupo possa estar relacionada ao próprio tamanho da instituição, permitindo maior ou menor grau de promoção de autonomia as crianças.

Embora não seja nosso objetivo discutir sobre a constituição do espaço e o papel do adulto especificamente, quando se olha para os contextos próprios em que as crianças deste estudo estão inseridas, levanta-se a hipótese de que as possíveis diferenças relacionais e, portanto, desenvolvimentais individuais, podem estar relacionadas à organização do ambiente e do papel atribuído à criança com deficiência intelectual e de seus educadores.

O segundo aspecto que marca a identificação das diferenças entre os sujeitos diz respeito às diferenças quantitativas nas iniciativas das regulações de comportamento em situações com compartilhamento de objeto ou atenção conjunta. Conforme demonstrado abaixo, na tabela 12, as regulações de comportamentos foram iniciadas na maioria das vezes pela criança pivô, no caso Ivan; pelos pares, no caso Inácio; e, de forma equilibrada entre pares e a criança pivô no caso Amanda.

Tabela 12. - Mapeamento das interações em situações de compartilhamento de objetos ou atenção conjunta.

\begin{tabular}{lcc}
\hline Caso & Iniciativas pela criança pivô & Iniciativas pelos pares \\
\hline Inácio & 71 & 122 \\
Ivan & 122 & 93 \\
Amanda & 85 & 80 \\
\hline
\end{tabular}

Em estudos comparativos entre grupos de crianças com déficit intelectual e grupos de crianças sem déficit (Gowen, Johnson-Martin, Goldman \& Hussey, 1992: Legerstee \& Weintraub, 1997), conduzidos em situações controladas, reporta-se maior incidência de comportamentos de atenção conjunta no grupo de crianças sem deficiência em comparação com crianças com déficit intelectual. Tais estudos sustentam que a habilidade de coordenar (integrar) a atenção entre objeto e a outra pessoa desenvolve-se mais lentamente em crianças com déficit intelectual e apontam que, em decorrência disso, crianças com déficit intelectual são mais passivas em situações de interação. A partir de tais 
estudos, há indicação de que crianças com déficit intelectual em fase escolar apresentam menor incidência de atenção conjunta e que tenham maiores dificuldades no estabelecimento de situações de interação. Contudo, embora não se tenha conduzido um estudo similar aos supracitados (comparativo e em situação controlada), a análise dos dados aqui apresentados chama a atenção para o papel ativo dessas crianças com déficit intelectual nas situações de interação com seus pares, que inclusive, envolviam o compartilhamento de objetos, com atenção conjunta.

As particularidades apontadas até então mostram que, independentemente da situação (com ou sem compartilhamento de objeto ou atenção conjunta) todos os três sujeitos (crianças pivô) apresentaram um papel ativo nos processos de regulação do comportamento. Na situação sem compartilhamento de objeto ou atenção conjunta, esse papel ativo é identificado na atenção voluntária, necessária para que a ação do sujeito (criança pivô) seja organizada a partir de um foco específico da ação do outro (o par). E, na situação de compartilhamento de objeto ou atenção conjunta esse papel ativo é identificado a partir das incidências em que é a criança pivô quem regula o par.

O papel ativo em direção ao par evidencia a relevância desse, marcando a relação emocional entre sujeitos, o que para Gonzalez Rey (1995) é primordial na constituição do desenvolvimento, uma vez que o outro precisa ser alguém significativo, para que se constitua como fonte desse processo. Todavia, esse papel ativo (essa atividade) é circunscrito pelo contexto e pelos aspectos particulares da constituição de cada sujeito, definindo caminhos diversos para o processo de desenvolvimento e evidenciando a necessidade de se investigar o como essas regulações são construídas na relação com os pares caso a caso.

\section{Estudo de caso Inácio}

Em relação às especificidades no caso Inácio, destaca-se como elemento particular a relevância dos pares preferenciais e o estabelecimento de uma dinâmica particular de interação com estes. As evidências dessa particularidade residem na quantidade de interações estabelecidas com cada um dos pares (50\% das regulações de comportamento foram com quatro pares específicos: Lorena, Aline, Felipe e Pedro Augusto) e a priorização do foco de atenção nas ações do par preferencial quando em situações de interação em grupo, (i.e., Inácio foca sua atenção nas ações de pares específicos).

Na tabela 13 apresentada abaixo, explicita-se o mapeamento das interações em que ações de pares regularam o comportamento de Inácio em situações com o compartilhamento de objetos ou atenção conjunta. A tabela 13 mostra, ainda, a relação entre quantidade de episódios interativos, pares envolvidos e o contexto em que ocorreram. 
Tabela 13. - Mapeamentos dos pares preferenciais em situações de regulação de comportamento com compartilhamento de objeto e atenção conjunta iniciados por Inácio.

\begin{tabular}{|c|c|c|c|}
\hline Pares envolvidos & Incidências de regulações & Total & Contexto \\
\hline Alice & $\begin{array}{l}1 \\
4 \\
5\end{array}$ & 10 & $\begin{array}{l}\text { Educação Física } \\
\text { Sala de aula } \\
\text { Espaço Cultural }\end{array}$ \\
\hline Ana Laura & $\begin{array}{l}5 \\
2\end{array}$ & 7 & $\begin{array}{l}\text { Espaço Cultural } \\
\text { Sala de aula }\end{array}$ \\
\hline Arthur & $\begin{array}{l}2 \\
1 \\
1\end{array}$ & 4 & $\begin{array}{c}\text { Sala de aula } \\
\text { Espaço Cultural } \\
\text { Pátio }\end{array}$ \\
\hline Breno & $\begin{array}{l}6 \\
1 \\
1\end{array}$ & 8 & $\begin{array}{c}\text { Sala de aula } \\
\text { Educação Física } \\
\text { Pátio }\end{array}$ \\
\hline Felipe & $\begin{array}{l}9 \\
2\end{array}$ & 11 & $\begin{array}{c}\text { Sala de aula } \\
\text { Brinquedoteca }\end{array}$ \\
\hline Gabriela & $\begin{array}{l}4 \\
1 \\
2\end{array}$ & 7 & $\begin{array}{c}\text { Sala de aula } \\
\text { Espaço Cultural } \\
\text { Pátio }\end{array}$ \\
\hline Heitor & 1 & 1 & Sala de aula \\
\hline Isabela & $\begin{array}{l}5 \\
1\end{array}$ & 6 & $\begin{array}{l}\text { Sala de aula } \\
\text { Pátio }\end{array}$ \\
\hline João Pedro & $\begin{array}{l}2 \\
1 \\
2\end{array}$ & 5 & $\begin{array}{l}\text { Brinquedoteca } \\
\text { Pátio } \\
\text { Educação Física }\end{array}$ \\
\hline Lorena & $\begin{array}{c}2 \\
14 \\
6 \\
7 \\
5 \\
2 \\
1\end{array}$ & 32 & $\begin{array}{c}\text { Musicalização } \\
\text { Sala de aula } \\
\text { Espaço Cultural } \\
\text { Brinquedoteca } \\
\text { Pátio } \\
\text { Educação Física } \\
\text { Refeitório }\end{array}$ \\
\hline Elisa & 1 & 1 & Sala de aula \\
\hline Maria Gabrielly & 2 & 2 & Sala de aula \\
\hline Maria Luiza & 3 & 3 & Sala de aula \\
\hline Mateus & 2 & 2 & Sala de aula \\
\hline Murilo & 2 & 2 & Sala de aula \\
\hline Paula & 1 & 1 & Sala de aula \\
\hline Pedro Augusto & $\begin{array}{l}6 \\
2 \\
1\end{array}$ & 9 & $\begin{array}{c}\text { Sala de aula } \\
\text { Brinquedoteca } \\
\text { Refeitório }\end{array}$ \\
\hline
\end{tabular}


Rebeca

Alunos de outras turmas
Sala de aula

Pátio e Espaço Cultural

Pelo mapeamento, destaca-se a expressiva participação de Lorena que, para além da quantidade de regulações no comportamento da criança pivô $(n=32)$, também apresentou a maior variedade de situações em diferentes espaços do contexto escolar (e.g., musicalização, sala de aula, espaço cultural, brinquedoteca, pátio, educação física e refeitório). Ao se olhar para as interações com Lorena, identifica-se que as regulações de comportamento estão presentes conforme a tabela 14 abaixo:

Tabela 14. - Mapeamento das regulações de comportamento envolvendo o par Lorena, caso Inácio.

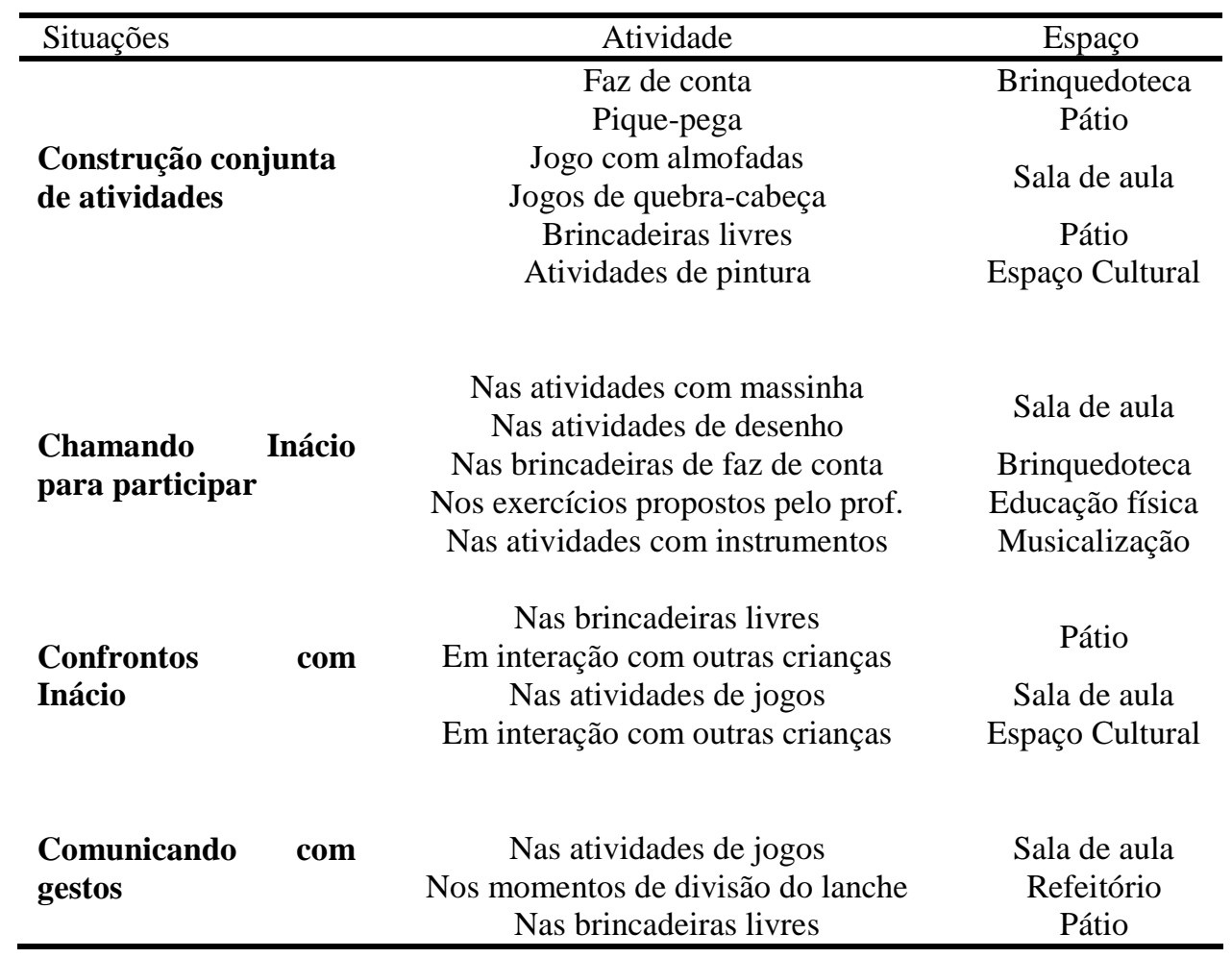

A regulação de comportamento a partir dos movimentos de Lorena é frequente, contínua ao longo de todo o ano letivo e recíproca, na medida em que são identificadas regulações de comportamento originadas a partir de ambas crianças: Lorena regula o comportamento de Inácio em 26\% (32 vezes) do total de situações e Inácio regula o comportamento de Lorena em $25 \%$ (18 vezes) do total de situações de regulação iniciadas pela criança pivô. Abaixo, traz-se um exemplo que destaca a interação entre Lorena e Inácio. 


\section{Inácio em: "Fazendo de conta no faz de conta da Lorena"}

\section{Data: 29 de Julho de 2014, registro n.1 aos 7'}

Contexto: A turma (total de dezoito crianças) está na brinquedoteca e a professora anuncia que as crianças podem brincar livremente, com todos os brinquedos disponíveis. As crianças estão explorando suas opções, selecionando os brinquedos, os lugares e os pares com os quais eles vão brincar. Entre os materiais e brinquedos disponíveis, Inácio escolhe para si um martelo que estava na pilha de brinquedos de Matheus. Ele observa e tateia o brinquedo enquanto a professora (localizada à sua frente) conta para ele o que o martelo faz "o martelo é para martelar, para construir", "ele bate, martela". Inácio bate com o martelo no chão e depois bate aleatoriamente em diferentes lugares ao seu redor.

Descrição da cena: Inácio, que na figura 50 está usando um capacete de construtor amarelo e segurando um martelo de brinquedo, está em pé olhando para um grupo de crianças brincando. Lorena, que está usando um traje azul, vê Inácio, aproxima-se dele e chama sua atenção tocando em seu ombro e dizendo-lhe "Inácio, a minha casa está quebrada". Inácio imediatamente olha para Lorena sem fazer grandes movimentos. Lorena repete: "minha casa está quebrada. Vem!". A professora, que se encontra agachada perto logo a frente das crianças, ao ouvir o que Lorena fala, se vira, olha para Inácio e enfatiza a fala da colega dizendo: "Olha! A casa dela está estragada! Olha só vai lá!'”. Lorena toca Inácio mais uma vez chamando-o, vai caminhando em direção ao outro lado da sala e repete: "a minha casa está estragada". Inácio segue Lorena atravessando a área da "cozinha". Durante o caminho, Inácio olha em direção a outras crianças brincando e diminui a velocidade dos passos. Lorena, que observa Inácio com o olhar chama-o novamente "Aqui Inácio oh! Por aqui! Eles trocam contato visual por algumas vezes e Inácio continua seguindo Lorena. Quando chegam ao canto, onde estão os brinquedos (uma casa de bonecas, bancada, panelas $e$ vasos) de Lorena, ela diz: "Aqui Inácio, é aqui oh! (apontando para o brinquedo) como que explicando para ele onde precisa ser consertado. Inácio bate com o martelo no brinquedo várias vezes, revezando o olhar entre o objeto e Lorena. Lorena acompanha os gestos de Inácio e diz: "Aqui, olhe. Isto não é bom. Aqui que tá estragado". Inácio martela em diferentes áreas e Lorena senta na cadeira e brinca com sua boneca. Inácio olha mais uma vez para Lorena, vira-se em direção a outro grupo de crianças e bate com o martelo em um banco.

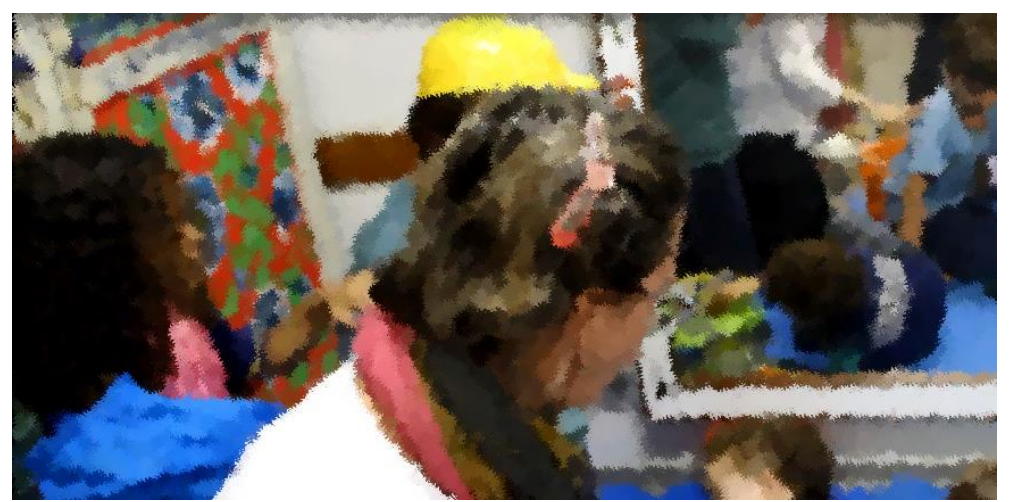

Figura 57. Lorena toca no ombro de Inácio, chamando sua atenção. 


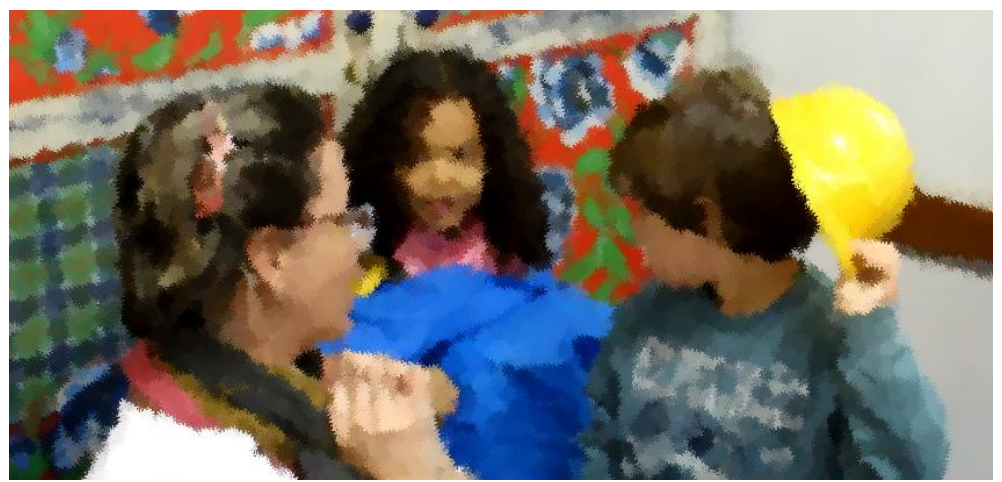

Figura 58. Professora enfatiza a fala de Lorena para Inácio.

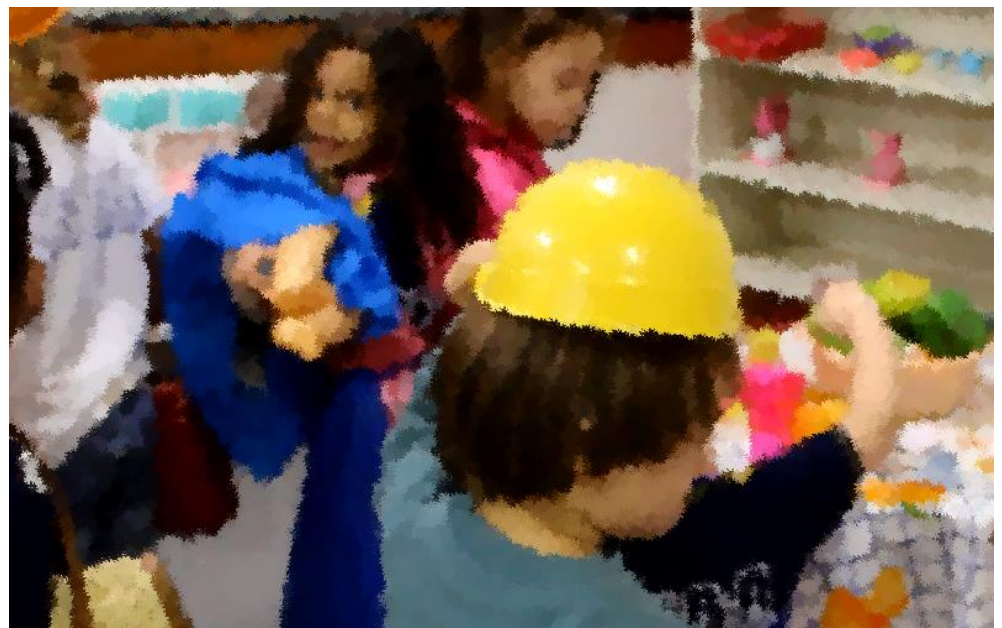

Figura 59. Lorena chama Inácio para que ele a siga.

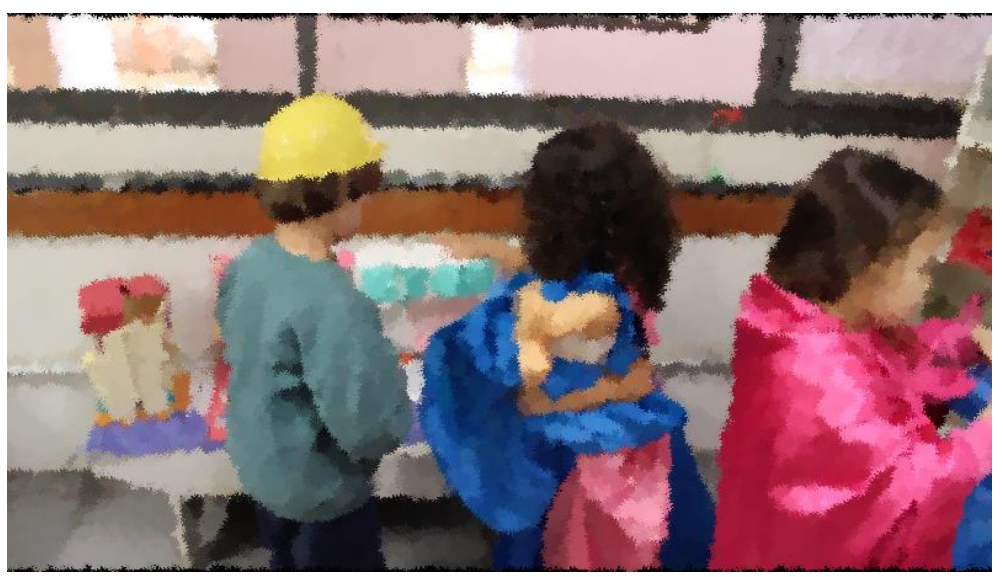

Figura 60. Lorena indica onde Inácio deveria consertar. 


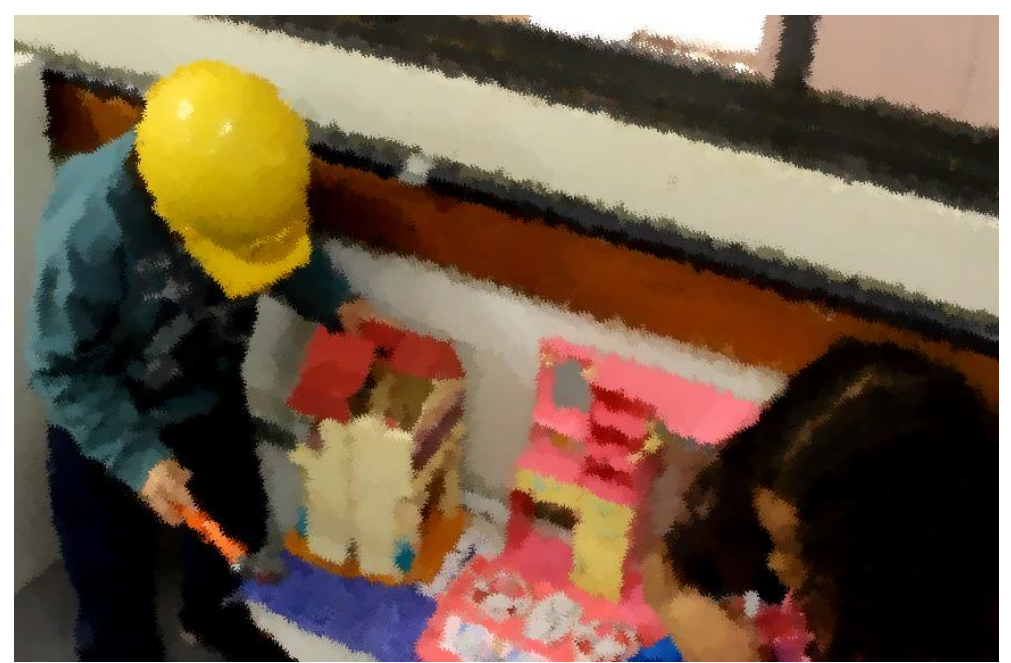

Figura 61. Inácio bate com o martelo nos brinquedos indicados por Lorena.

Quando Vygotsky, ao discutir sobre as relações entre aprendizagem e desenvolvimento, afirma que a aprendizagem cria a ZDP, ele discute que

$$
\begin{aligned}
& \text { “(...) o aprendizado desperta uma variedade de processos internos } \\
& \text { de desenvolvimento, que são capazes de operar somente quando } \\
& \text { a criança interage com pessoas em seu ambiente e em cooperação } \\
& \text { com seus companheiros. Uma vez internalizados, esses processos } \\
& \text { tornam-se parte das aquisições do desenvolvimento independente } \\
& \text { da criança” (Vygotsky, 2007. 103). }
\end{aligned}
$$

E, ao defender que a criança com déficit intelectual ${ }^{32}$ não deveria ser excluída ou segregada, Vygotsky assim o faz sustentado pela ideia de que as transformações qualitativas são provenientes de ações coletivas ou atividades cooperativas (Vygotsky, 2004a), indicando o aspecto processual do conceito de ZPD. Entende-se que esse episódio auxilia no entendimento dessa perspectiva processual da ZPD, evidenciando como a ação do par (nesse caso Lorena), na atividade coletiva (brincadeira de faz de conta), estrutura condições (contextualiza a brincadeira e oferece os elementos que compõem o cenário) para que a criança pivô (Inácio) desenvolva uma atividade de forma mais complexa (a atividade do fazer de conta de ser construtor, mas agora com elementos que demandam dele participar de uma história). Ao chamar Inácio para a atividade, Lorena oferece a ele uma história para o faz de conta: o papel social a ser representado (de 'alguém que conserta'), a estrutura do enredo (moça que chama o rapaz para consertar a casa quebrada) e o local da cena (a casa), construindo assim o cenário

\footnotetext{
32 Termo utilizado por Vygotsky era retardo mental.
} 
em que as ações podem ser criadas (e.g., consertar a casa), aumentando a complexidade de elementos (e.g., enredo, local, papel social e etc.) que não estavam presentes na atividade anterior de Inácio sem o par. Ao mesmo tempo, o par vai mostrando através das falas, gestos e expressões faciais, quais são os elementos constituintes dessa criação do faz de conta, permitindo e demandando que Inácio participe dentro do contexto compartilhado. Na brincadeira de faz de conta com Lorena, Inácio experimenta uma linguagem mais complexa, com narrativas, negociação de papéis e a narração do enredo da brincadeira, configurando um sistema descrito em estudos anteriores relacionados à construção de cultura entre pares na infância (Corsaro \& Molinari, 1990; Carvalho \& Pedrosa, 2002; Corsaro, 2005).

Outro aspecto importante a ser destacado para o entendimento sobre a relevância do par preferencial para Inácio diz respeito à priorização do foco da sua atenção nesses pares específicos. Isso significa que, em situações em que Inácio está em atividade coletiva com diferentes pares, a criança pivô tende a focalizar sua atenção em um par específico (o par preferencial). Tal processo foi identificado através das regulações de comportamento em atividades em grupo e, para elucidar, apresenta-se outro episódio, agora com o par preferencial Felipe.

\section{Inácio em "Meu olhar segue seu gesto e seu gesto guia o meu fazer"}

\section{Data: 03 de abril de 2014, gravação (2) aos 3'40',}

Contexto geral: Os alunos são divididos em grupos de quatro, para realizarem uma atividade de colagem que tem relação com a história contada previamente. A professora explica para a turma toda que a tarefa consiste em molhar o dedo no pote de cola, aplicar a cola nos pedaços de papel que estão sobre a mesa e fazer uma colagem utilizando a folha de papel que está à frente de cada aluno. A colagem é simultaneamente orientada (i.e., a professora orienta os alunos no que deve ser feito) e individual (i.e., cada aluno é responsável pela produção do seu próprio trabalho), as crianças sendo solicitadas a se inspirarem na história que a professora contou naquele mesmo dia.

Descrição da cena: Inácio (identificado pela flecha na figura 22) participa do grupo, em que também estão Maria Luiza, Felipe e Matheus. O grupo inicia a atividade imediatamente após as orientações da professora. Enquanto Maria Luiza escreve seu nome na folha de papel, Matheus e Felipe esticam os braços em direção ao pote de cola. Inácio apenas olha, com os olhos direcionados nas mãos de Felipe. Depois, Inácio olha para Felipe, para a cola, para o papel picotado sobre a mesa e para Felipe novamente, passando cola no pedaço de papel e o posicionando na folha em branco. A mesma ação é feita em seguida por Matheus e Maria Luiza. Inácio continua com olhar nas mãos de Felipe. Inácio estica os braços em direção ao pote de cola, introduz seu dedo dentro do pote. A professora passa pela mesa, nesse momento. Ela se abaixa, segura o braço de Inácio e passa o dedo dele na borda do potinho de cola, retirando o excesso de cola do dedo da criança. Ao mesmo tempo, a 
professora fala "é só um pouquinho de cola". Inácio permanece olhando para o pote de cola até que a professora solta seu dedo e ele então passa a cola no papel e volta a olhar para Felipe.

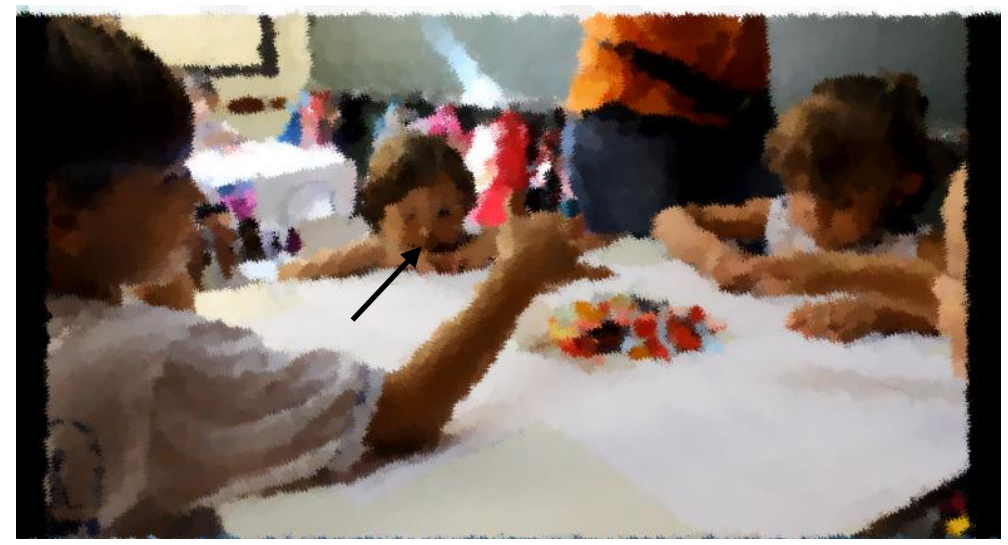

Figura 62. Inácio olha para as mãos do colega Felipe enquanto este molha o dedo com cola.

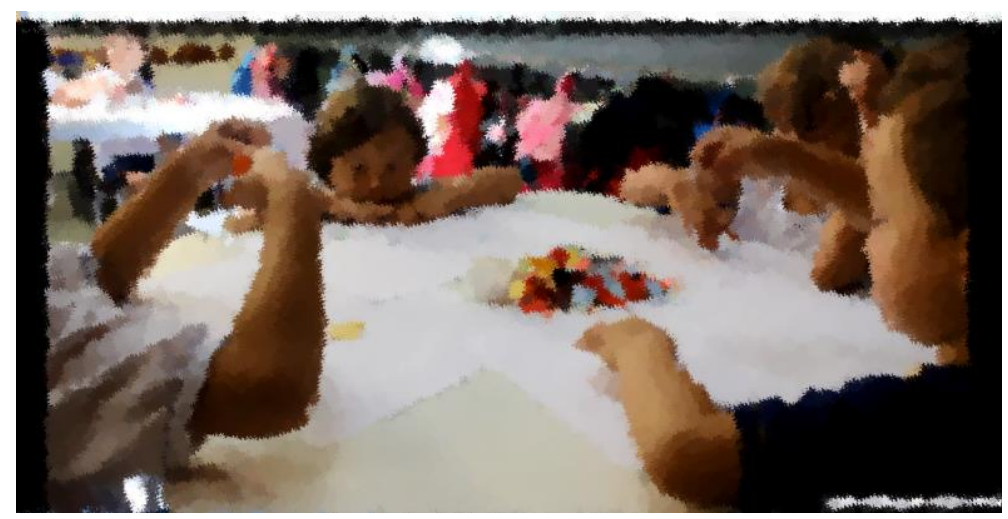

Figura 63. Inácio olha para as mãos de Felipe, enquanto ele passa cola no papel com os dedos.

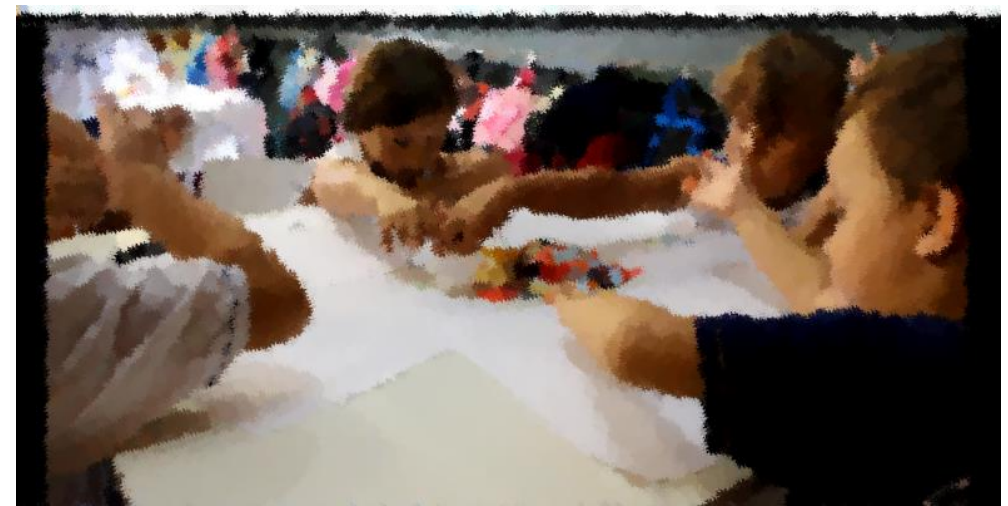

Figura 64. Inácio coloca seu dedo no pequeno pote de cola. 


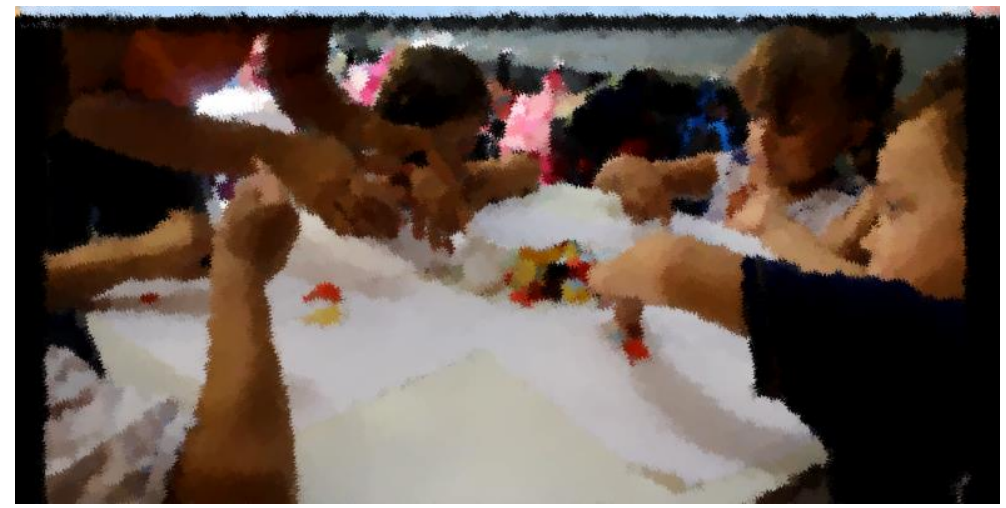

Figura 65. Professora auxilia Inácio a limpar o dedo com cola.

Sobre o processo de desenvolvimento da personalidade e autoconsciência da criança, Wallon (2007) afirma que não existe ato motor sem que haja um ato mental que o sustente e que o processo de controle dos comportamentos perpassa a relação estabelecida com o outro. Segundo Carvalho, Bastos, Rabinovich e Sampaio (2006), a espécie humana atribui qualidade às relações que estabelece com o outro, o que significa que há diferentes possibilidades de interação a depender desse valor a ele atribuído. Os "vínculos são entendidos como um padrão diferencial de interações entre parceiros em uma situação social " (Carvalho el al, 2006, p.590), e possibilitam que os compartilhamentos de significado sejam maximizados. Carvalho e Rubiano (2004) já apontavam para a relevância dos vínculos entre pares preferenciais, destacando a abreviação do processo comunicativo como sendo um de seus elementos marcadores.

Esse episódio mostra a particular dinâmica (i.e., orientação do olhar, manifestação de gestos, etc.) que Inácio estabelece com seus pares preferenciais (neste caso Felipe) em meio a atividade em grupo, mostrando como os comportamentos regulatórios estão mais diretamente relacionados às ações do par específico (Felipe), embora imerso num contexto coletivo, com os demais pares (Maria Luiza e Matheus). Ao longo do episódio, Inácio observa Felipe (i.e., olha continua e atentamente para as mãos, rosto e objetos que Felipe usa) no seu movimento de colar os picotes de papel. A atividade cinética (movimento propriamente dito) constitui-se nos movimentos oculares no seguimento dos movimentos do par, em uma reação postural (função tônica) que possibilita a contemplação. Gradativamente, ao longo desse processo, entende-se que a contemplação (Wallon, 2008) vai criando condições de ação em potencial na medida em que torna possível o controle dos comportamentos impulsivos e a observação do conjunto de movimentos envolvidos na atividade (e.g., passar cola no picote de papel e posicioná-lo na folha em branco). O par, nesse sentido, é quem oferece os elementos estruturantes do processo.

No curso do episódio, essa ação em potencial é materializada na imitação dos comportamentos que definem a atividade (colagem), observadas nas regulações de comportamentos subsequentes 
(comportamentos de Inácio ao esticar o seu braço em busca de colocar o dedo no pote de cola e assim por diante). Para Wallon, a imitação "é, ao mesmo tempo, participação e desdobramento do ato, contradição que anuncia o nascimento da representação e revela sua importância para o desenvolvimento psicológico da criança (Costa, 2000, p.34)”; uma forma de atividade que incontestavelmente revela as origens motoras do ato mental, e através da qual, para Vygotsky, encontram-se as origens das características de consciência especificamente humanas que desenvolve a criança (Holzman, 2010).

Dessa forma, em síntese, o conteúdo dos comportamentos regulatórios na imitação em atividades coletivas ou na construção de atividades de faz de conta mostraram colaborar no entendimento do papel das atividades colaborativas entre pares no processo de aprendizagem, e consequentemente, para o desenvolvimento de Inácio. A relevância do par preferencial para Inácio, seja pela análise da frequência de interações (discutido com a apresentação do episódio de Lorena) ou pela identificação da função da priorização da atenção (discutido com a apresentação do episódio com Felipe), abre espaço para a discussão sobre o significado do outro no processo de aprendizagem e o desenvolvimento pelo ponto de vista que integra cognição e afeto. Esta perspectiva é para González Rey (2011) imprescindível para a compreensão de conceitos centrais da teoria de Vygotsky, tal qual é a ZDP.

\section{Estudo de caso Ivan}

$\mathrm{Na}$ análise das particularidades das interações de Ivan com seus pares, os dados revelam que foi estabelecido um processo interativo diversificado, em que se alternaram ao longo do ano, os grupos com os quais ele mais interagia. De uma forma geral, seis colegas aparecem com mais frequência: Carlos, Arthur, Eduardo, Carla, Nicolas e João Paulo (conforme tabela 15). Entretanto, aqui vale lembrar que, em $65 \%$ das situações de regulação de comportamento, o posicionamento de Ivan no espaço (e.g., lugar de se sentar na sala de aula) foi escolhido pelo adulto (monitora ou professora), contribuindo para o estabelecimento de interações com pares específicos. Na análise das situações em que Ivan escolheu onde e com quem interagir, João Paulo (contexto de sala de aula), Nicolas (pátio) e Eduardo (brinquedoteca) mostraram-se como os pares que mais se destacaram.

Tabela 15 - Mapeamentos das interações com os pares em situações de regulação de comportamento com atenção conjunta iniciadas por Ivan.

\begin{tabular}{lccc}
\hline Pares envolvidos & Incidências de regulações & Total & Contexto \\
\multirow{3}{*}{ Teresa } & 1 & & Educação Física \\
& 3 & 5 & Sala de aula \\
& 1 & & Espaço Cultural
\end{tabular}




\begin{tabular}{|c|c|c|c|}
\hline Carlos & $\begin{array}{l}3 \\
8 \\
1\end{array}$ & 12 & $\begin{array}{l}\text { Espaço Cultural } \\
\text { Sala de aula } \\
\text { Educação Física }\end{array}$ \\
\hline Arthur & $\begin{array}{l}6 \\
3 \\
3 \\
1 \\
1\end{array}$ & 13 & $\begin{array}{c}\text { Sala de aula } \\
\text { Espaço Cultural } \\
\text { Pátio } \\
\text { Educação Física } \\
\text { Brinquedoteca }\end{array}$ \\
\hline Eduardo & $\begin{array}{l}6 \\
3 \\
5\end{array}$ & 14 & $\begin{array}{c}\text { Sala de aula } \\
\text { Brinquedoteca } \\
\text { Pátio }\end{array}$ \\
\hline Otávio & $\begin{array}{l}7 \\
2\end{array}$ & 9 & $\begin{array}{c}\text { Sala de aula } \\
\text { Brinquedoteca }\end{array}$ \\
\hline Luis & $\begin{array}{l}4 \\
1 \\
2\end{array}$ & 7 & $\begin{array}{c}\text { Sala de aula } \\
\text { Espaço Cultural } \\
\text { Pátio }\end{array}$ \\
\hline Tadeu & $\begin{array}{l}2 \\
1\end{array}$ & 3 & $\begin{array}{c}\text { Sala de aula } \\
\text { Brinquedoteca }\end{array}$ \\
\hline Carla & $\begin{array}{l}7 \\
2 \\
4\end{array}$ & 13 & $\begin{array}{c}\text { Sala de aula } \\
\text { Pátio } \\
\text { Brinquedoteca }\end{array}$ \\
\hline Nícolas & $\begin{array}{l}4 \\
4 \\
1 \\
4\end{array}$ & 13 & $\begin{array}{c}\text { Brinquedoteca } \\
\text { Pátio } \\
\text { Refeitório } \\
\text { Sala de aula }\end{array}$ \\
\hline João Paulo & $\begin{array}{l}9 \\
3 \\
2 \\
1\end{array}$ & 15 & $\begin{array}{c}\text { Sala de aula } \\
\text { Espaço Cultural } \\
\text { Brinquedoteca } \\
\text { Educação Física }\end{array}$ \\
\hline Gabriela & 2 & 2 & Sala de aula \\
\hline Vitoria & 2 & 2 & Sala de aula \\
\hline Luiza & 3 & 3 & Sala de aula \\
\hline Pedro & $\begin{array}{l}4 \\
2 \\
1\end{array}$ & 5 & $\begin{array}{c}\text { Sala de aula } \\
\text { Pátio } \\
\text { Brinquedoteca }\end{array}$ \\
\hline Ana Claudia & 3 & 3 & Sala de aula \\
\hline Laila & 1 & 1 & Sala de aula \\
\hline Ana & $\begin{array}{l}3 \\
2\end{array}$ & 5 & $\begin{array}{c}\text { Sala de aula } \\
\text { Brinquedoteca }\end{array}$ \\
\hline Evandro & 1 & 1 & Sala de aula \\
\hline
\end{tabular}


Ao se analisar os processos de regulação de comportamento identificou-se que a imitação, assim como no caso anterior, permeia a interação entre Ivan e seus pares e contribui para a construção de diferentes atividades. Todavia, neste processo destacam-se dois aspectos que são particulares ao caso Ivan: (1) a focalização da atenção por estímulos específicos (sons ou imagens), no objeto e seu uso ou no movimento na ação do par (e.g., movimento do braço no arremessar de um objeto); e, (2) uma ação exploratória em meio ou a partir do processo imitativo. Abaixo, apresentam-se três episódios que ilustram, em diferentes situações, os pontos aqui ressaltados, permitindo uma discussão mais aprofundada.

\section{Ivan em: "Uma grande ideia"}

\section{Data: 29 de maio 2014, gravação (3) aos 7'40',}

Contexto geral: Os alunos estão em momento de atividade livre no pátio. Ivan machucou a orelha raspando-a na parede do muro da quadra e para aliviar a sensação de dor a enfermeira da escola lhe deu um saco com gelo, para ser colocado em sua orelha. Ivan permanece com esse saquinho de gelo na orelha andando pelo pátio entre os brinquedos até que Nicolas vem ao seu encontro.

Descrição da cena: Nicolas caminha ao encontro de Ivan e lhe conta sobre fala "Ivanzinho, você quer brincar comigo? Eu tive uma grande ideia... É joga isso aqui oh (apontando para o papel em sua mão), lá dentro do escorregador. Não é uma grande ideia? (Balançando a cabeça em sinal afirmativo". Ivan balbucia algo incompreensível. Nicolas continua: "Então vamos lá brincar" e pula da mureta onde estavam em direção ao chão. Ivan olha no entorno, coloca a bolsa de gelo na orelha, desce da mureta com a ajuda do corrimão, cruza o pátio vagarosamente em direção ao escorregador, às vezes trombando com diferentes colegas que correm de um lado ao outro. Em determinado momento, Ivan avista Nicolas e outras crianças (Pedro, Luis e Arthur) brincando no topo do escorregador. Ele se vira em direção a elas. De cima do escorregador, as crianças atiram pedaços de papel. Ivan tenta arremessar o saco de gelo que estava em suas mãos, a que Nicolas fala: "Ivanzinho, mais forte". Ivan tenta novamente sem sucesso. Nicolas diz aos demais colegas: "deixa eu ajudar ele" e escorrega em direção a Ivan. Ivan olha para Nicolas vindo em sua direção e olha para o saquinho plástico quando Nicolas aterrissa no chão. Nicolas fala para Ivan "deixa eu te ajudar" e pega o saco de gelo da mão de Ivan. Os olhos de Ivan estão direcionados ao saco plástico. Nicolas arremessa o saco plástico em direção ao topo do escorregador onde os demais colegas estão. Ivan olha para os colegas no topo do escorregador. O saco de gelo volta a deslizar escorregador abaixo. O movimento se repete agora com Ivan arremessando o saco. A monitora da turma se aproxima e questiona o uso do saco de gelo para brincadeira: "Ivan, eu te dei o gelo para você brincar? Isso não é para brincar é para colocar no machucado, na orelhinha”. Ivan aponta para o escorregador e continua a arremessar o saco plástico em direção ao topo do escorregador onde está Nicolas. A monitora vira-se e se afasta do escorregador, deixando as crianças brincarem. Ivan olha para o saco plástico, olha para os colegas no topo do escorregador (vozes são ouvidas, mas não é possível entender o que as crianças estão falando), olha para Nicolas e arremessa, continuando a dinâmica estabelecida. Nicolas olha para Ivan arremessando o saco de gelo, vira-se e corre em direção às escadas que ficam na parte de trás do escorregador e as sobe. Enquanto isso, Ivan continua os arremessos com os demais colegas no topo do escorregador. Nicolas está no topo do 
escorregador novamente e volta a jogar, lá de cima, o saco de gelo para Ivan. As crianças continuam nessa atividade por mais, aproximadamente, quatro minutos.

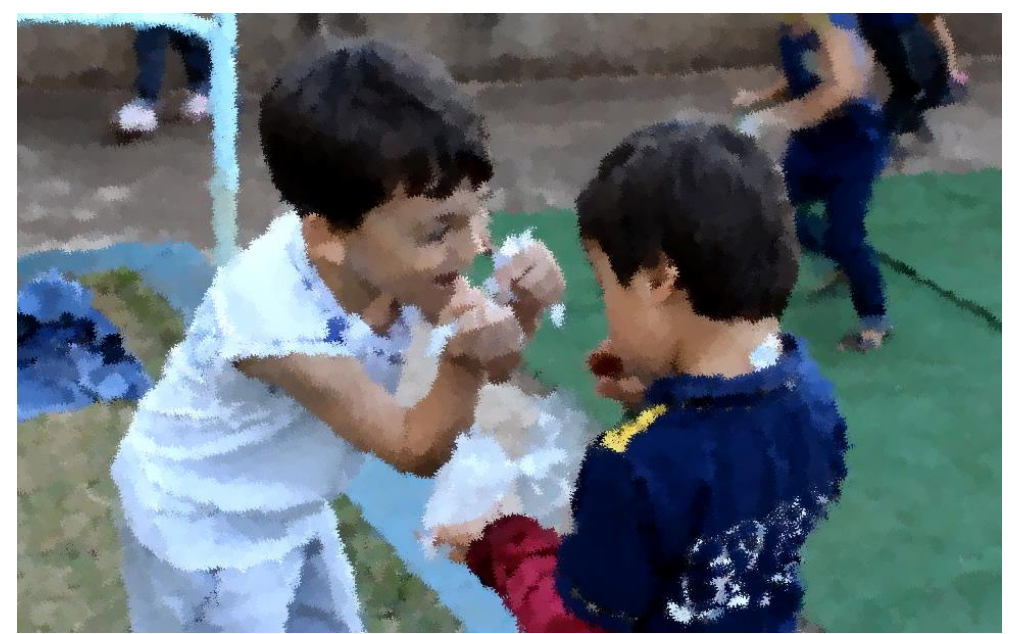

Figura 66. Nicolas conta para Ivan sobre sua ideia para a próxima brincadeira.

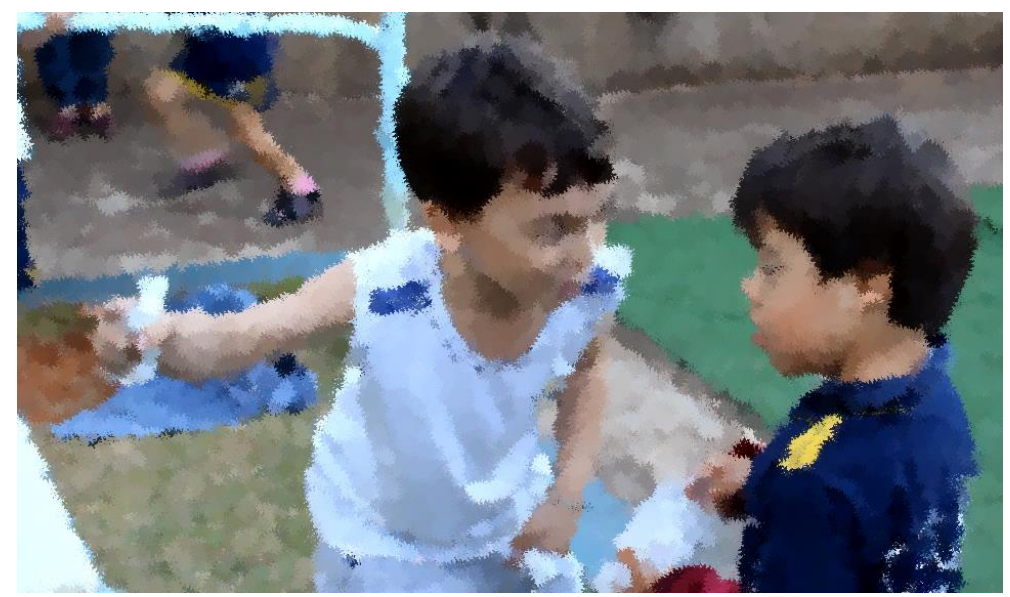

Figura 67. Nicolas aponta para o escorregador e Ivan olha na direção apontada pelo colega.

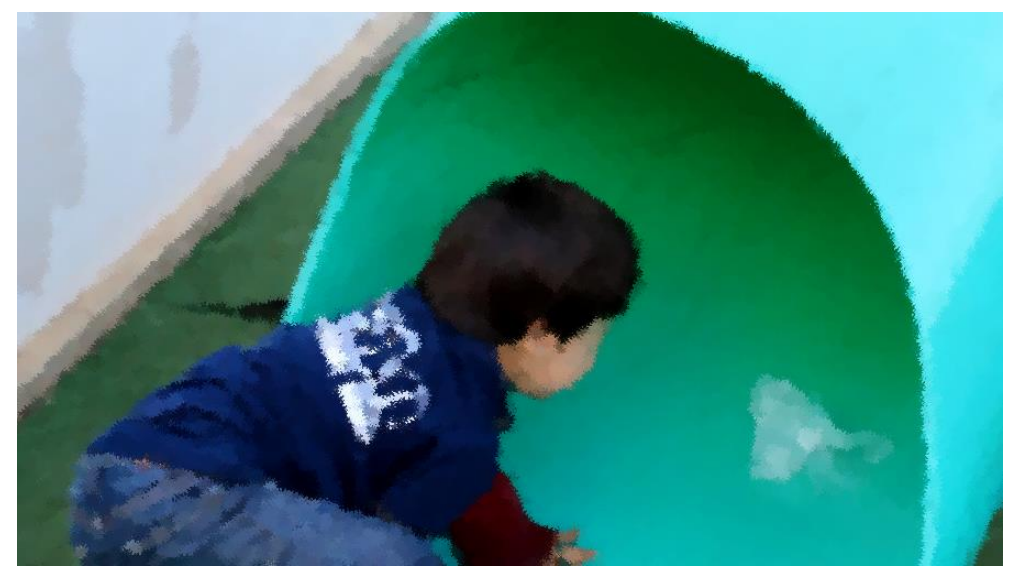

Figura 68. Ivan arremessa o saco plástico em direção aos colegas no topo do escorregador. 


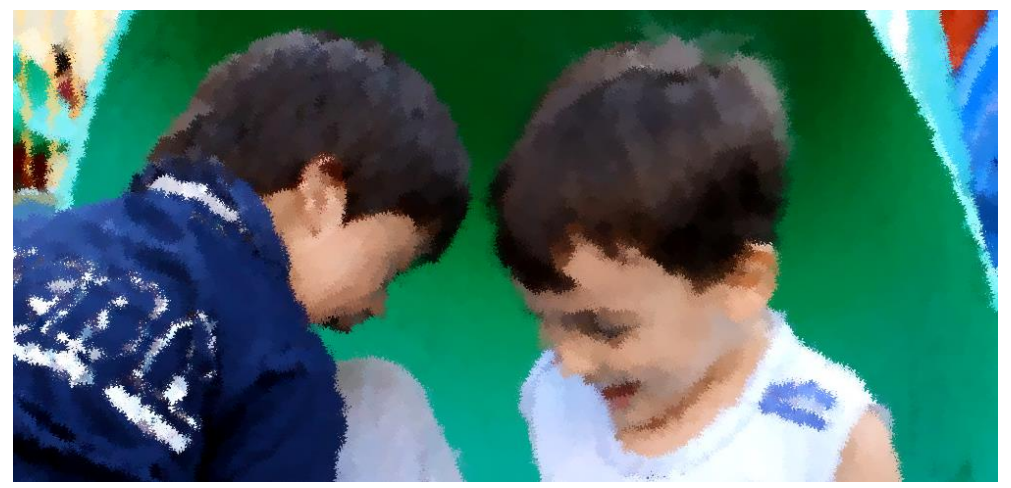

Figura 69. Nicolas escorrega em direção a Ivan após verbalizar que irá ajudar o colega a arremessar o saco plástico.

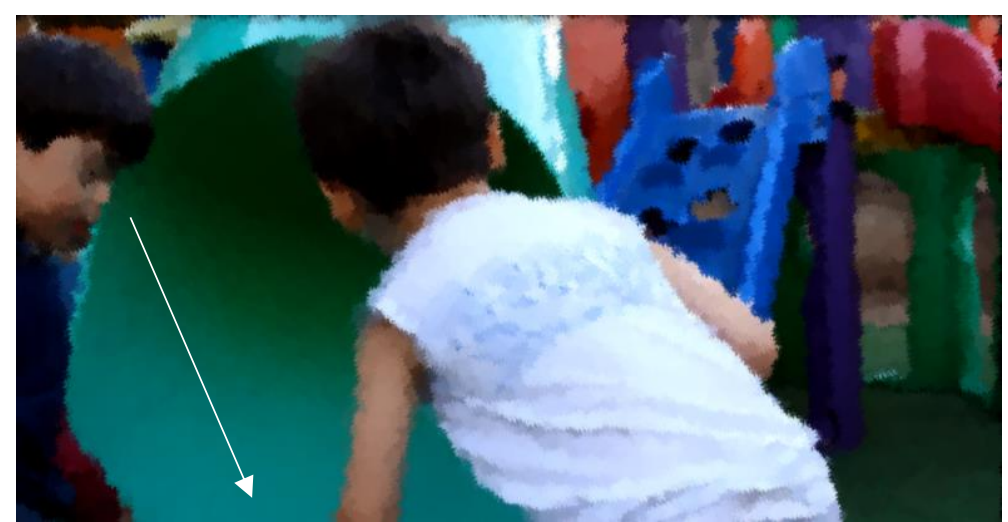

Figura 70. Ivan olha atentamente para o saco plástico nas mãos de Nicolas.

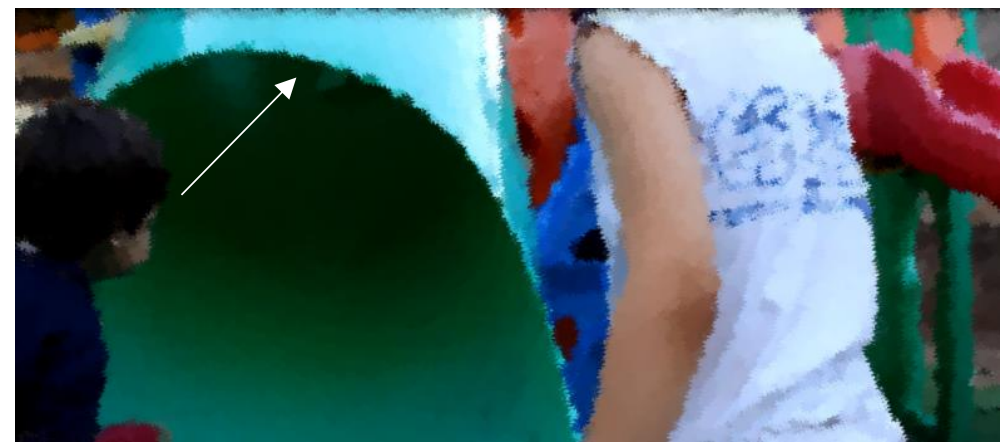

Figura 71. Ivan olha atentamente para o saco plástico indo em direção aos demais colegas no topo do escorregador.

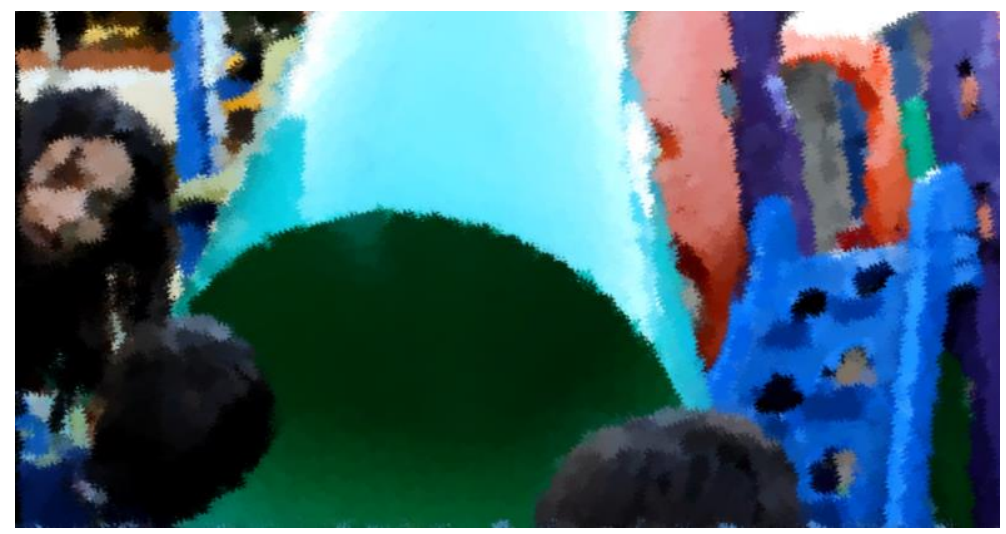

Figura 72. Monitora da turma questiona Ivan sobre o uso do gelo para a brincadeira. 


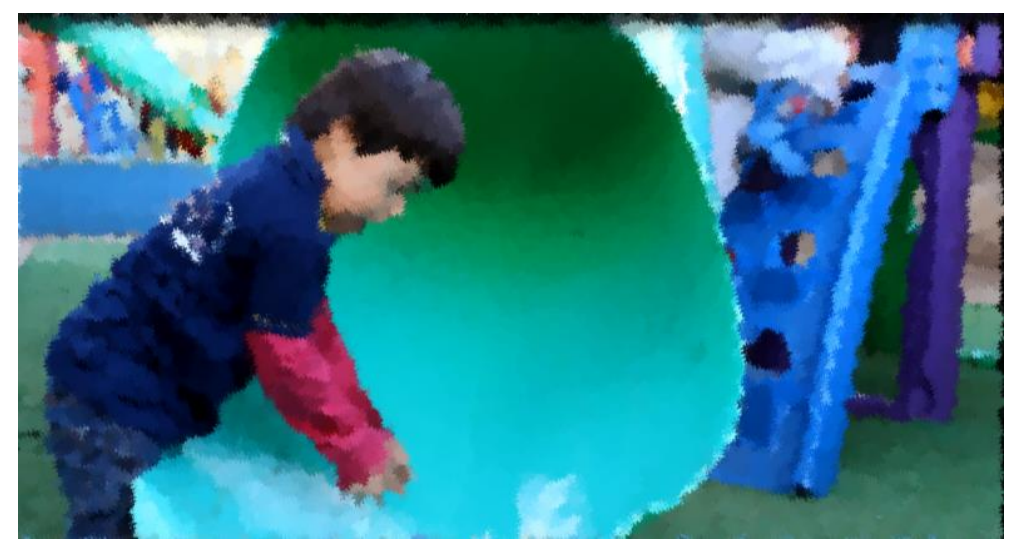

Figura 73. Nicolas abandona o local (indicado com a flecha vermelha) e Ivan continua a arremessar o saco de gelo no escorregador com os demais colegas.

Nas situações de interação em grupo, diferente de Inácio, a presença do par preferencial não necessariamente exerceu a função de priorização no foco de atenção. Ou seja, em situações de interação em grupo, Ivan não foca a atenção exclusivamente no par com que mais frequentemente estabelece interação. O foco da atenção de Ivan, nessas situações coletivas, está mais frequentemente direcionado aos objetos e ao seu uso ou às atividades, do que ao par em si. Neste episódio, como exemplo, Ivan não focaliza a atenção exclusivamente nas ações de pares específicos (par preferencial), como no caso de Inácio. A atenção de Ivan (foco do olhar e direção do movimento corporal) se divide entre os pares (Nicolas e demais colegas localizados no topo do escorregador) e o objeto utilizado na atividade (saco de gelo). Contudo, a análise microgenética do episódio revela outros elementos relevantes que constituíram esse processo interativo de Ivan com esses pares, com particular destaque à dinâmica estabelecida entre Ivan e Nicolas e a interferência direta do par na execução do movimento de Ivan até a sua autonomia na ação.

No início deste episódio, o par preferencial (Nicolas) conta para Ivan sua ideia sobre uma brincadeira: Nicolas verbaliza a ideia e com o suporte de gestos (apontar, tocar no colega) e expressões faciais (sorrir, arregalar os olhos), compartilha não só a ideia, como também a emoção que a acompanha. Bruner (1997) afirma que, antes mesmo da verbalização ser o veículo principal de troca e compartilhamento de significado na interação, os gestos, na manifestação da experiência corporal, são importantes recursos para a comunicação. São esses gestos e expressões emocionais que aqui dão suporte ao diálogo entre Ivan e Nicolas, que permite ao coetâneo criar o contexto da atividade para Ivan, expressando a ação a ser executada (jogar o papel), o local (no escorregador), o quando (agora) e quem serão os executores dessa atividade. Essa comunicação desencadeia a atividade coletiva em si, apesar de, inicialmente, Ivan não se engajar na mesma, a despeito da atenção dirigida à outra criança. Será mais adiante, quando Ivan avistar os colegas atirando pedaços de papéis do alto do escorregador, que ele imediatamente reproduz as ações das outras crianças, sua ação já 
modificada (afinal ele atira a bolsa de gelo e não papeis) podendo se mostrar entremeada às orientações verbais presentes no diálogo que se estabeleceu anteriormente com Nicolas.

No decorrer do episódio, destaca-se a ação de Nicolas que interfere diretamente na forma como Ivan executa os movimentos da atividade (arremessar o saco de gelo). Nicolas verbaliza qual é o elemento necessário (força) para que Ivan adeque seu movimento, diante das expectativas do grupo de receber no topo do escorregador o saco de gelo. Para essa tarefa, Ivan tem dificuldade, a que Nicolas, parecendo reconhecer a necessidade de auxílio de Ivan, desce do escorregador e mostra-lhe como se faz. Ao mostrar a Ivan como deve ser realizado o movimento de jogar o saco de gelo escorregador acima, Nicolas oferece um conjunto de elementos (postura, direção e movimento) que servem de modelo e que comporão em parte o processo de imitação por Ivan. Interações desse tipo assemelham-se àquelas descritas por Tomasello (2003) como engajamento coordenado conjunto, nas quais a criança se envolve com o par em interação social mediada por um objeto. Neste tipo específico de interação, Tomasello reconhece o compartilhamento de intencionalidades e a compreensão que a criança tem dos estados de atenção do seu co-específico e daqueles comportamentos relacionados à atividade específica; ainda, ele afirma que tal processo implica em intensa negociação de significados.

Todavia, para Ivan, a atenção difundida entre os colegas e o objeto (saco de gelo) e a ausência de um período de observação, constroem um processo imitativo em que os movimentos são impulsivamente manifestados, caracterizando um processo de transição entre o mimetismo e a imitação simultânea, propriamente dita (Nadel, 1986 como citado por Galvão, 2001). Apesar da atenção e do tempo de reação na observação serem dois elementos que indicam a habilidade da criança para aprender pela imitação, ressaltando-os como fundamentais para o processo (Garfinkle \& Schwartz, 2002), há estudos que sugerem possíveis relações entre imitação e a aprendizagem acadêmica (Ledford, Gast, Luscre \& Ayres, 2008) ou a imitação e o dimensionamento dos comprometimentos cognitivos de crianças com diferentes déficits (Rogers, Hepburn, Stackhouse e Wehner, 2003). Contudo, ressalta-se que a coincidência entre a estrutura perceptiva e a estrutura motriz a ela correspondente, expressas nos comportamentos desse episódio de imitação, evidenciam as tensões contraditórias que são próprias da transição da união mimética à imitação e, posteriormente, do processo de desenvolvimento da representação (Wallon, 2008).

Ainda, é importante destacar as corregulações nos comportamentos de Nicolas e Ivan, já que Nicolas observa (mantém o olhar) os movimentos de Ivan ao tentar arremessar o saco de gelo após sua interferência. Ao vê-lo realizar a ação em questão (Ivan consegue gradativamente arremessar o saco de gelo forte o suficiente para alcançar os colegas no topo do escorregador), Nicolas volta para sua posição de origem, no topo do escorregador. Esse processo oferece indícios de que, na brincadeira coletiva, o par de idade pode, em situações diversas, mediar de forma direta (com o objetivo de 
provocar uma mudança no comportamento do outro) a criança com déficit intelectual, levando esta a desenvolver habilidades que não conseguia de forma autônoma, anteriormente a essa mediação.

Dessa forma, mesmo em se adotando a perspectiva operacional do conceito de ZDP, encontrada na segunda fase dos trabalhos de Vygotsky (González-Rey, 2011), em que a ZDP é caracterizada pela "distância entre o nível de desenvolvimento real, que se costuma determinar através da solução independente de problemas, e o nível de desenvolvimento potencial, determinado através da solução de problemas sob orientação de um adulto ou em colaboração com companheiros" (Vygotsky, 2007, p.97), pode-se apontar que, neste episódio, mediante o problema (arremessar o saco de gelo a fim de que ele alcance os colegas no topo do escorregador), foi a ação voluntária (advinda da criança) e intencional (contém um objetivo) do par de mediar a ação de Ivan, que possibilitou a adequação dos seus movimentos (força e direção), levando Ivan a solucionar o problema, ou seja, conseguir realizar o movimento autonomamente.

\section{Ivan em: "O que é isso aí? "}

\section{Data: 01 de dezembro 2014, gravação (1) aos 11'}

Contexto geral: Os alunos da turma de Ivan estão na brinquedoteca e podem escolher livremente os brinquedos e os parceiros na interação. A monitora senta perto de Ivan e está, ao longo de todo o tempo, acompanhando o que ele faz. Nesta cena, Ivan e Eduardo irão utilizar um brinquedo que consiste em deslizar um carrinho de madeira (de cima para baixo) em uma plataforma vertical também de madeira, que contém estruturas curvilíneas que delimitam o espaço e a forma como o carrinho irá descer. No processo de deslizamento, o movimento de descida do carrinho gera um efeito fluído, rápido e atrativo, que aparentemente chama a atenção das crianças.

Descrição da cena: Ivan encontra-se sentado, mexendo com os animais de brinquedo do cenário de fazendinha. Eduardo, sentado a menos de dois metros de distância na diagonal direita de Ivan, mexe com um brinquedo de madeira. Ivan olha para o colega imediatamente após a emissão de um som vindo do brinquedo que Eduardo está utilizando. Ivan levanta-se e segue em direção a Eduardo e senta-se ao seu lado (a monitora o ajuda a equilibrar-se na descida ao chão). Enquanto se senta, Ivan mantém seu olhar no brinquedo; depois Ivan olha para o Eduardo que está colocando o carrinho de brinquedo para deslizar no 'labirinto vertical'. Ambos olham o carrinho deslizar. Eduardo afasta-se um pouco do brinquedo e Ivan aproxima-se. Ivan pega o carrinho e tenta posicioná-lo na plataforma, ele vira o carrinho em várias direções buscando encaixá-lo nos espaços vagos, mas o carrinho não desliza. Ivan olha para Eduardo (que neste momento apenas observa). Ivan tenta colocar o carrinho na plataforma inferior, mas o carrinho cai. Enquanto isso, Eduardo ora olha para Ivan e ora para a monitora da sala, fala algo no ouvido da monitora. Eduardo volta o olhar para Ivan, aponta para o topo do brinquedo e verbaliza algo inaudivel. Ivan tenta novamente, o carrinho caindo de sua mão. Ivan pega-o e gira para outro lado. Durante a tentativa de Ivan, a plataforma vertical perde a estabilidade e balança de um lado para o outro. Eduardo ajuda segurando o brinquedo. A monitora vê e também segura a ponta superior do mesmo, dando 
estabilidade a esse. Ivan coloca o carrinho na plataforma. O carro não desliza. Ambos (monitora e Eduardo) param de apoiar o brinquedo. Ivan volta a tentar posicionar o carrinho na plataforma vertical mudando-o novamente de direção. Eduardo fala algo para a monitora (incompreensível). Em um dos movimentos, Ivan consegue fazer o carrinho deslizar do topo do brinquedo até o chão. Ambas crianças olham o carrinho deslizar. Ivan começa a reposicionar o carrinho novamente na plataforma e a atividade continua.

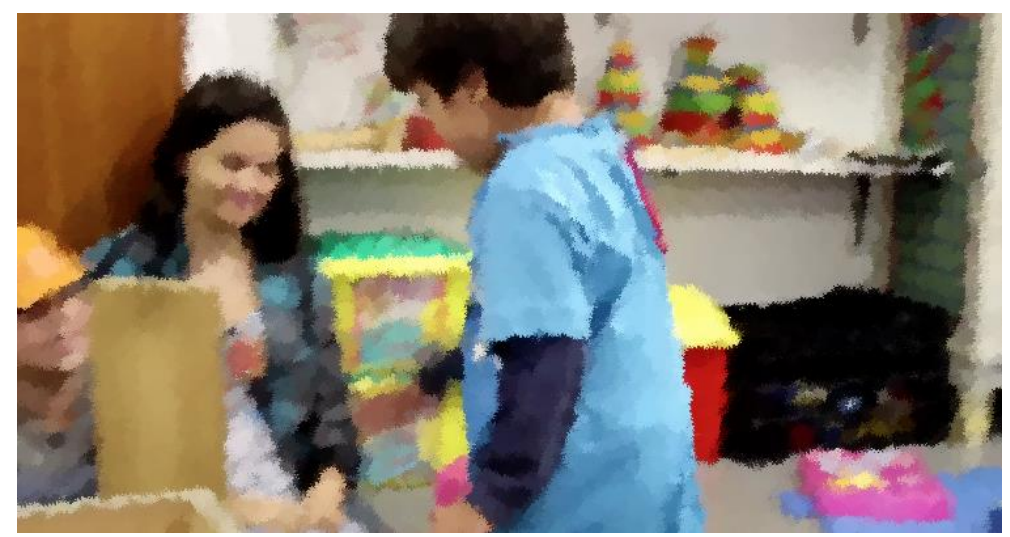

Figura 74. Ivan caminha em direção a Eduardo.

A regulação de comportamento neste episódio inicia pela percepção do som produzido pela ação de Eduardo ao utilizar o brinquedo de madeira. Estímulos sonoros e visuais (e.g., sons diversos, objetos que emitem luz, ou produzem algum tipo de movimento peculiar) estiveram presentes em $61 \%$ das situações em que pares regulam os comportamentos de Ivan. Majoritariamente, demarcam o início do processo de regulação, focalizando a atenção da criança pivô. Contudo, na análise do desenrolar desse episódio, observa-se, por meio das sucessivas regulações, que a atenção de Ivan é redirecionada para os movimentos do par e para a exploração do objeto (brinquedo de madeira), abrindo-se espaço para a construção coletiva de uma atividade culturalmente dada (brincar com o colega), em que o som e o movimento agora fazem parte do objetivo final da ação (fazer o carrinho deslizar), a aprendizagem perpassando a relação com o outro na atividade.

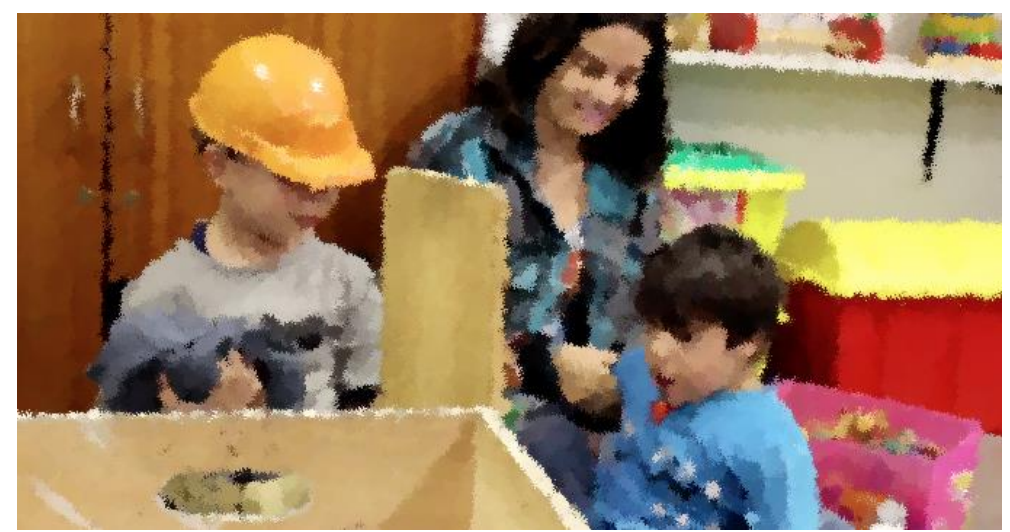

Figura 75. Ivan olha para o carrinho de madeira que desliza no brinquedo. 


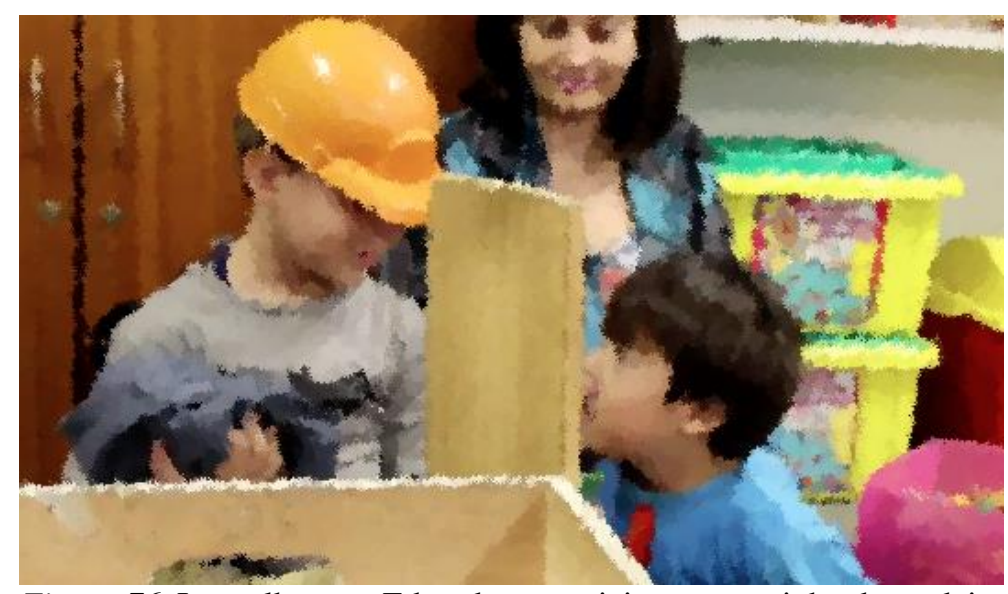

Figura 76. Ivan olha para Eduardo ao posicionar o carrinho de madeira e fazê-lo deslizar

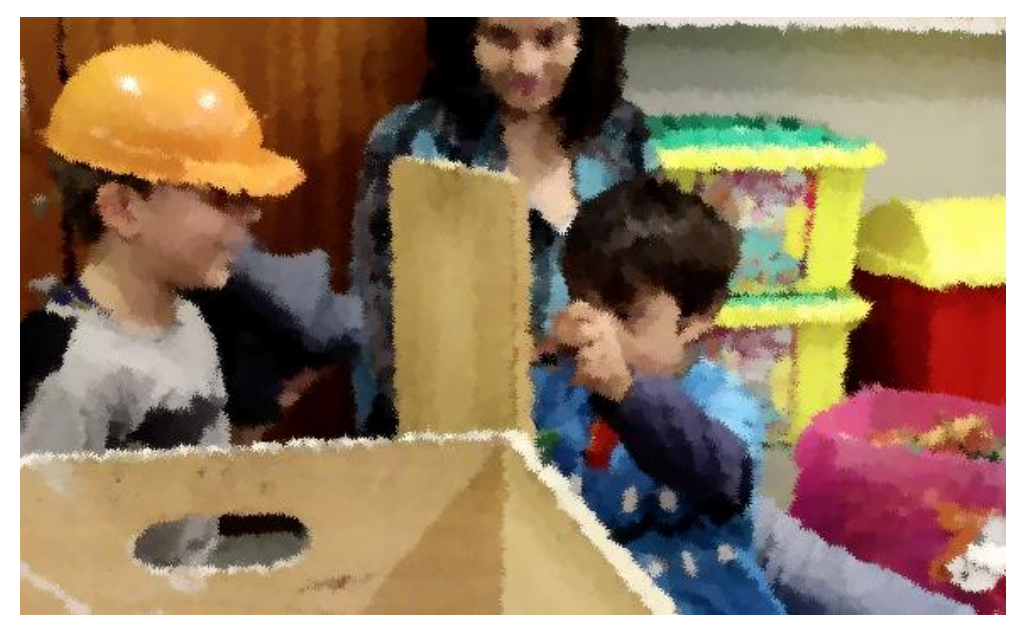

Figura 77. Ivan tenta posicionar o carrinho de madeira para fazê-lo deslizar.

A mediação inicia na própria negociação do uso do objeto e espaço pelas crianças que, através da linguagem corporal, manifestam e compartilham as representações (regras e expectativas) de uma cultura institucional específica (aula na brinquedoteca). Ao movimentar-se em direção a Eduardo, olhar para ele enquanto ele posiciona o carrinho de madeira na plataforma vertical e aguardar que a ação iniciada pelo par se complete, Ivan sinaliza seu interesse pelo processo em curso. Eduardo, em contrapartida, aceita a aproximação e convida Ivan para o compartilhamento, na medida em que olha para o colega, afasta-se (sutilmente) do objeto abrindo-lhe espaço e oferecendo-lhe a vez quando o deixa pegar o brinquedo e tentar. Segundo Galvão (2001), dinâmica tal como a aqui apresentada, revela um conceito mais amplo de interação em que se incluem as mediações nas relações das pessoas com as produçõeslestruturas culturais historicamente acumuladas.

Para além, pares entram em acordo no uso do objeto por meio de uma negociação não verbal. Segundo Amorim (2008), essa negociação pode ser identificada na alternância e sequencialidade dos comportamentos (e.g., olhar, esperar, afastar-se, caminhar em direção a e etc.) e constitui-se enquanto elemento que revela o processo de construção e compartilhamento de significados nas ações das 
crianças. A continuidade da mediação é observada nos processos de regulação e corregulações subsequentes entre os pares.

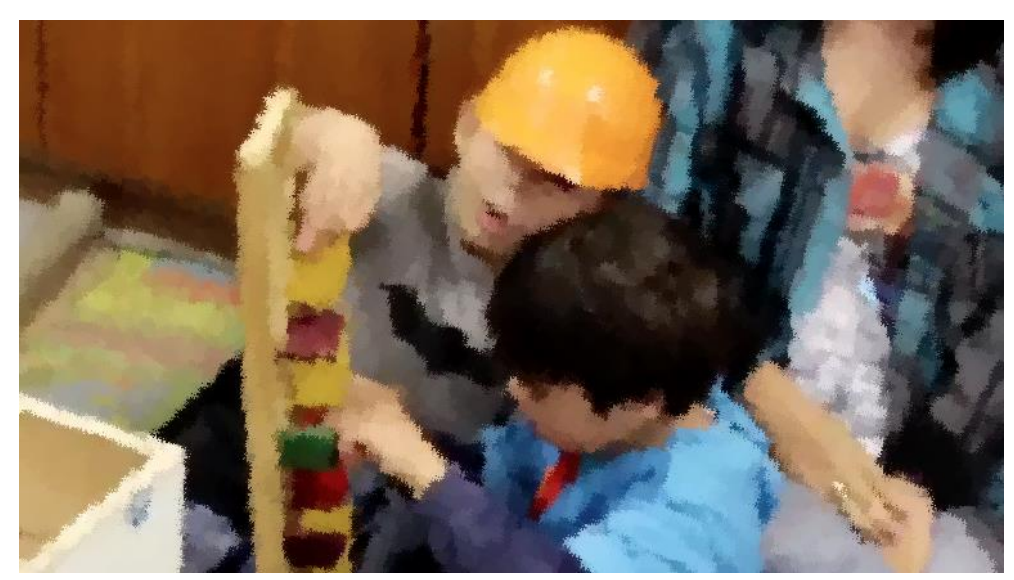

Figura 78. Eduardo indica com a mão no topo do brinquedo onde é o início do processo.

Durante as tentativas de Ivan em fazer o carrinho deslizar, observa-se que ele olha para Eduardo de tempos em tempos, especialmente logo após sua tentativa de posicionar o carrinho 'fracassar' (já que não desliza). Especula-se que essas trocas de olhares signifiquem a busca de Ivan pelo apoio do par, ou a tentativa de manter Eduardo engajado na atividade coletiva. É uma situação similar à narrada por Trevarthen (1993) em seus estudos sobre a função das emoções na comunicação infantil, em que o ato de olhar para o outro (mãe) imediatamente após a manifestação de movimentos específicos da ação em curso, é interpretado como mecanismo instintivo de regulação do outro em atividades compartilhadas desde os primeiros meses de vida. Independente do conteúdo motivacional intrínseco, o que se observa é que Eduardo reage a esses olhares com sucessivas e sequenciais aproximações (indicando o lugar de posicionar o carrinho e segurando o brinquedo para Ivan) e por meio de comportamentos que oferecem a Ivan os elementos necessários para a realização da atividade.

Novamente identifica-se intencionalidade nas ações do par em auxiliar a criança pivô na realização da atividade em questão e, mais além, uma mediação que acontece por comportamentos que apoiam e oferecem os indícios necessários para que a criança pivô realize as atividades autonomamente. Neste episódio, diferente do anterior, o par não repete a ação (fazer o carrinho deslizar) para que Ivan veja e possivelmente faça igual, mas Eduardo indica a posição e direção (aponta com o dedo verbalizando a instrução) e oferece as condições de suporte (segura a plataforma vertical) para que o colega continue no seu processo individual. 


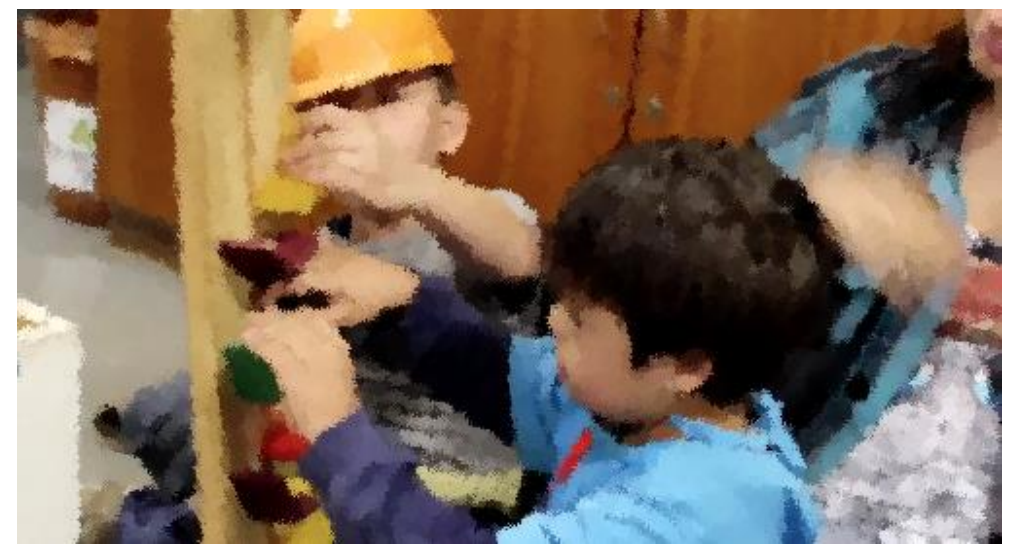

Figura 79. Ivan tenta posicionar o carrinho de madeira para fazê-lo deslizar e Eduardo segura o brinquedo que balança.

Lucena (2010), ao estudar a forma pela qual as crianças assimilam, constroem e compartilham cultura em contextos institucionais, afirma "que a despeito da idade, a forma prioritária de intercâmbio entre as crianças, que organiza o processo de construção de suas brincadeiras, é a reprodução da ação do parceiro" (p. 140). Também aqui, como no episódio anterior, identifica-se o processo de imitação. Contudo, observa-se que neste episódio os comportamentos expressos ao longo do processo de imitação estão diretamente relacionados e dependentes ao modelo, configurando uma imitação imediata (Galvão, 2001).

Parte desse processo possivelmente decorre do fato de que o contexto (aula na brinquedoteca) possa oferecer a estrutura da atividade cultural a ser desenvolvida, em que uma das regras consiste no compartilhamento dos objetos. A dinâmica e divisão do tempo (aula de noventa minutos majoritariamente, com atividades livres), bem como a estrutura física do espaço da brinquedoteca (divisão em distintos ambientes por meio de materiais específicos), oferecem elementos que viabilizam o engajamento em atividades coletivas e, possivelmente, o compartilhamento dessa cultura 'do-fazer-com-o-par' que é, neste caso, institucionalizada, mas que também é construída na individualidade da relação entre as crianças. O brinquedo em uso em si também deve ser considerado nessa análise: uma estrutura de madeira que demanda apoio para ser utilizada possibilitaldemanda a ação coletiva para seu uso.

Não obstante, identificam-se na análise microgenética desse episódio, indícios referentes à organização das ações do par e de sua intencionalidade no auxílio da criança pivô, que permitem uma discussão inédita sobre o conceito de scaffolding (Wood, Bruner \& Ross, 1976), que tem sido amplamente utilizado para explicar uma função diádica ou de auxilio nas interpretações do conceito de ZDP de Vygotsky, segundo Holzman (2010). O conceito de scaffolding, originário do trabalho Wood, Bruner e Ross (1976) a partir dos pressupostos teóricos de Vygotsky e no enfoque na ZDP, aponta como elemento chave para a identificação do processo de aprendizagem e de desenvolvimento desse sujeito, a partir da relação de ajuda com o outro, a presença de dois fatores: (1) o controle dos 
elementos que constituem a atividade, ou seja, que o mediador saiba identificar, que tenha consciência do que é importante para que a atividade ocorra; e, (2) a intenção de que pela sua ação, o outro tenha condições de realizar essa atividade, ou seja, a intencionalidade. Dessa forma, o entendimento sobre a constituição da ZDP fica condicionada à situação em que o mediador se reconheça como aquele que auxilia o outro no seu processo de aprendizagem, sabendo como propiciar, na situação de aprendizagem, que esses elementos sejam apresentados para o sujeito mediado.

Esse entendimento privilegiou o que Holzman (2010) vai chamar de visão diádica do conceito de ZPD, em que a estrutura da assistêncialajuda ao outro para a resolução do problema é o elemento que caracteriza o conceito. Inúmeros estudos no campo da educação e da educação especial têm utilizado tal compreensão para investigar como professores entendem, planejam e executam suas práticas frente às demandas no desenvolvimento de seus alunos (Butler, 1998; Gaskins et al., 1993; Mäkinen \& Mäkinen, 2011; Rosiek, 2003; Rueda \& Genzuk, 2007). Dentre eles, uma tradição de estudos privilegia a ação do adulto no contexto institucional.

Contudo, entende-se que os dados apresentados nesta análise revelam que, mesmo olhando pela perspectiva diádica do conceito de ZDP (Holzman, 2010), as regulações de comportamentos presentes nas interações entre pares revelam estrutura similar à desenhada por Wood, Bruner e Ross (1976). A intencionalidade pode ser interpretada através do tempo de espera, da troca de olhares e dos tipos de respostas frente aos problemas enfrentados por Ivan ao longo do processo. Eduardo não retira o brinquedo da mão do colega, não pega outro objeto similar para brincar em paralelo, ele interage em resposta ao que Ivan aparenta necessitar - ajuda para fazer o carrinho deslizar. A consciência da atividade pode ser observada e interpretada através dos comportamentos específicos que Eduardo utiliza para auxiliar o colega (indicações de como resolver o problema), em que Eduardo não solicita auxílio da monitora (alguém que representa oficialmente o papel social daquele que ensina), não repete ele mesmo a ação de fazer o carrinho deslizar. Ao contrário, ele medeia o processo indicando, orientando e oferecendo suporte para que, na interação, Ivan possa realizar a atividade ele mesmo.

\section{Ivan em: "Se você faz eu também posso fazer"}

\section{Data: 12 de dezembro de 2014, gravação (1) aos 7'29',}

Contexto geral: Os alunos estão no pátio da escola, em recreio, juntamente com crianças de outras turmas e anos de ensino. Ivan acaba de sair do banheiro e segue correndo em direção ao pátio. Sua turma está brincando no parquinho do outro lado do pátio. A monitora o acompanha de longe pois nesta instituição, durante o recreio, as crianças são encorajadas a brincarem entre si, sem que haja 
uma mediação direta dos professores. Os adultos, sejam eles professores ou monitores, interferem apenas em situações de conflito, ficando próximos e apenas observando as brincadeiras em curso pelas crianças.

Descrição da cena: Ivan (identificado pela flecha na figura 26) atravessava (correndo) o pátio em direção a um dos parquinhos. No caminho, ele avista uma outra criança subindo no poste de luz do pátio, localizado a sua direita. Ivan imediatamente para, gira o corpo para direita e, enquanto olha constantemente na direção da criança (Hugo) no poste, ele se redireciona e começa a caminhar no sentido do poste. Ao chegar próximo ao poste, ainda olhando para Hugo, Ivan coloca suas duas mãos e o seu pé direito na base da estrutura e olha para cima em direção ao menino que havia escalado. O colega (aluno mais velho, de outro ano de ensino) olha para Ivan, olha para a pesquisadora com a câmera e desce do poste. A esse movimento da outra criança, Ivan retira suas mãos e pés da estrutura e olha a descida do colega. Não há qualquer troca de palavras ou gestos entre as duas crianças. Após o colega sair de perto do poste, Ivan olha para ele mais uma vez. Depois, começa a fazer movimentos com pernas e braços, como se buscasse subir no poste. Ivan leva primeiramente o braço direito e em seguida busca com a perna direita achar um apoio para subir. Ele tateia com o pé, mas não acha nenhum objeto ou posição para se fixar. Ivan alterna a perna, mantendo o braço direito elevado, tateia com o pé esquerdo, mas também não acha apoio. Ivan segura com as duas mãos, flexiona as pernas (como se quisesse pular), ele estica o pé direito em direção à mureta do jardim, mas não alcança. Ele olha para pátio, na mesma direção na qual o colega tinha ido. Ivan tenta segurar-se nas folhas do arbusto a sua frente. Porém, ao puxar as folhas, estas se movimentam em sua direção (não oferecem resistência) e, posteriormente, soltam-se. Ivan permanece imóvel por alguns instantes, olha para o pátio novamente, olha para o chão e inicia sua descida, colocando o pé direito em direção ao chão enquanto ainda segura seu corpo com as mãos no poste.

Neste episódio, a regulação de comportamento diferencia-se das anteriormente apresentadas pois acontece com um par aleatório (i.e., não é par preferencial, não pertence à mesma turma ou ano de ensino, criança que aqui é chamada de $\mathrm{Hugo}^{33}$ ), mas assemelha-se a elas, na medida em que o processo de interação aconteceu em um dos momentos e espaços em que Ivan tem autonomia para escolher com quem interagir. Objetiva-se aqui apresentar dois aspectos considerados relevantes sobre a regulação de comportamento entre pares quando analisado a partir das particularidades do caso Ivan: (1) a atenção voltada para a açãolmovimentolatividade; e, (2) a atuação do par preferencial na estruturação do processo interativo.

\footnotetext{
33 Foi solicitada, via contato telefônico, a autorização dos pais para o uso da cena nas análises e nas descrições que serão publicadas na tese. Como a criança não faz parte da turma de Ivan, não era previsto o Termo de Consentimento Livre e Esclarecido a priori. A imagem da criança deve, contudo, ser preservada, assim como as das demais crianças.
} 


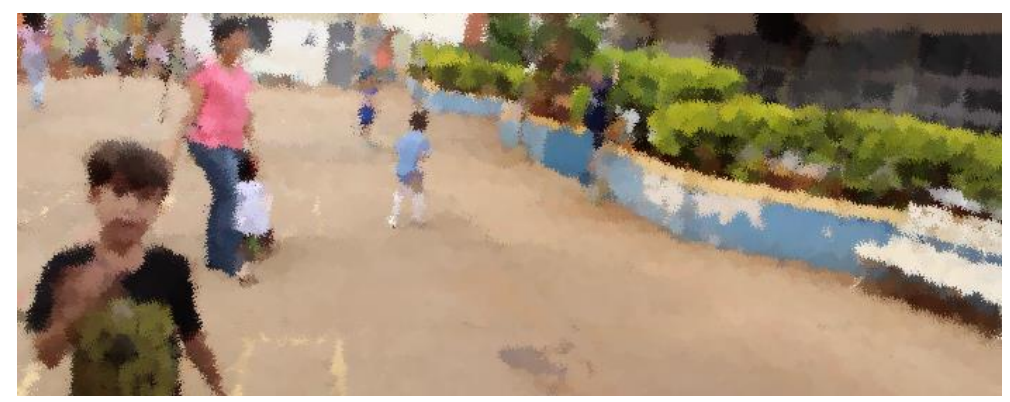

Figura 80. Ivan (camiseta azul clara) olha ao colega (seta branca) subindo no poste.

Hugo, através de uma atividade até então individual e inespecífica (escalar o poste de luz), regula o comportamento de Ivan. Este, imediatamente após olhar para Hugo, interrompe o seu percurso inicial (caminhar em direção ao parque, demarcando mudança da intenção da ação), modifica a direção de seu caminhar e, com os olhos fixos na direção de Hugo, aproxima-se dele. Esses comportamentos e essa particular dinâmica sugerem que o movimentolação de Hugo seja o elemento que atrai a atenção de Ivan. Nesse sentido, julga-se relevante entender o papel do corpo, da açãolmovimento na construção desse processo de interação, uma vez que esse elemento está presente em 39\% das vezes em que pares regularam os comportamentos de Ivan.

Amorim e Rossetti-Ferreira (2008), durante sua investigação sobre comunicação e significação entre bebês, referem que o ser humano apresenta recursos diferenciados de comunicação e significação ao longo da vida e que diferentes estímulos (sonoros, visuais táteis, olfativos e etc.) são utilizados nesse processo, revelando inúmeras relações entre o corpo, as emoções, as ações, a constituição da criança e o desenvolvimento da própria linguagem. Em suas conclusões, as autoras afirmam que a corporeidade contribui para construir a cultura, pois é através do corpo que a criança descobre e (co)constrói o mundo e a ela mesma, possibilitando a diferenciação eu - outro tão importante para o desenvolvimento humano (Amorim \& Rossetti-Ferreira, 2008). Dessa forma, pode ser também através do corpo e da expressão da sua corporeidade que se possa analisarlcompreender a ação da criança junto a seus pares. Esse referencial possibilita levantar a discussão de que seja também através do corpo que a criança pequena e, aqui neste caso a criança com déficit intelectual, buscaria os elementos a serem compartilhados \significados, mesmo que com pares inéditos. O corpo - seus movimentos e gestos - é o intermediário da relação dialógica (pois ele expressa as significações por gestos e ações), e simultaneamente é também o foco ou a fonte primária de atenção para a criança pequena, uma vez que é através dele que ela percebe, apreende e compartilha o mundo. Tal perspectiva auxilia na compreensão das possíveis razões que levam Ivan a ter, em 43 de seus registros de interação seus comportamentos regulados a partir dos movimentos e ações de pares, mesmo que seja com aqueles com quem ele nunca interagiu anteriormente. 
Na continuação da análise deste episódio, identifica-se o movimento de contemplação-exibição (Galvão, 2001) que explicita a diferenciação subjetiva entre os papéis daquele que escala (Hugo) e daquele que olha (Ivan), e que vai sustentar o que na sequência se desenvolverá na imitação do comportamento do par. O período de contemplação neste episódio está, contudo, delimitado a um ponto específico do processo da ação: Ivan olha para Hugo quanto ele já se encontra no alto do poste e não durante o processo de subida.

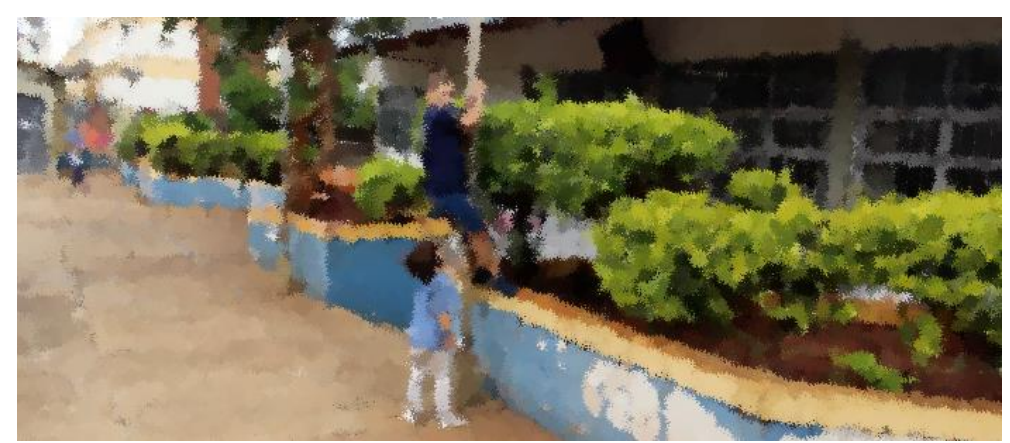

Figura 81. Ivan se aproxima do colega. Colega olhando para câmera.

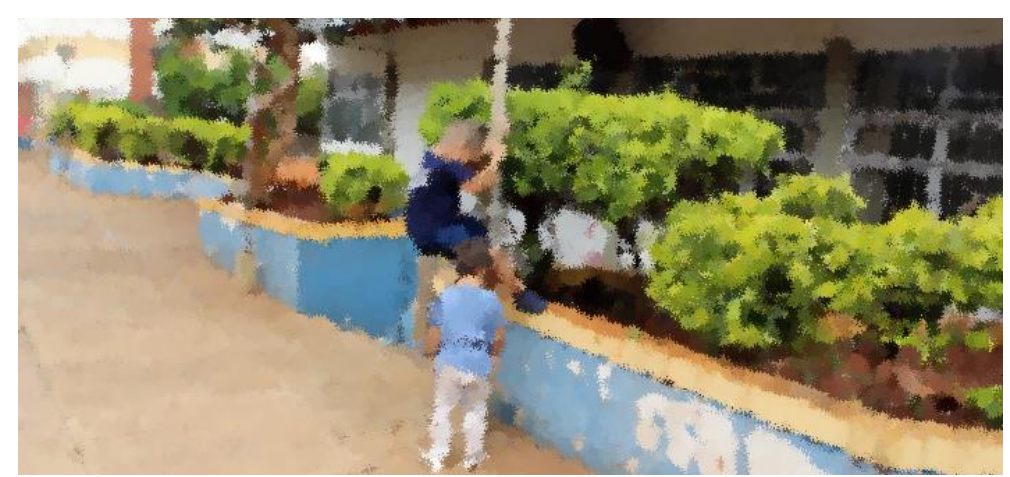

Figura 82. Colega de Ivan desce do poste.

Os comportamentos posteriores expressos por Ivan (e.g., colocar as mãos no poste, olhar em direção ao colega) estabelecem uma comunicação não verbal entre as crianças revelando a intenção sobre o uso do objeto (poste). Na sequência, Hugo sinaliza seu desengajamento no uso do objeto, olhando para Ivan (e, posteriormente, para a pesquisadora), imediatamente iniciando o processo de descida. A manifestação desses comportamentos funciona como um feedback, que sustenta a continuidade da intenção inicial de Ivan.

Aqui vale discutir que o olhar para a pesquisadora pode ter sido para Hugo o motivo pelo qual ele desce do poste, algo que pode estar relacionado à situação de vídeo-registro, ou mesmo de reconhecimento de que subir no poste seja algo inadequado e que tem um adulto olhando. Contudo, também se entende que, do ponto de vista da dinâmica de regulações e corregulações estabelecidas neste episódio, a ação motora da descida (independente do fator motivacional da criança) oferece a Ivan o feedback necessário para a continuidade de suas ações. 
Após a descida de Hugo do poste, Ivan tem para si a possibilidade do uso do objeto e ele então tenta subir no poste - imitando o resultado final da ação do colega. O elemento interessante neste episódio é que, diferente dos anteriores apresentados nesse caso, o processo imitativo em sequência, necessariamente, deveria ser realizado por meio da imitação diferida (Wallon, 2008), sem o modelo e assim, com base na representação da ação desempenhada por Hugo. Contudo, sem o modelo simultâneo, ou ações provenientes do par que o auxiliassem no processo (conforme nos episódios apresentados anteriormente), Ivan precisa descobrir caminhos para conseguir realizar parte da ação (escalar o poste) que ele não viu acontecer. O processo de imitação que ocorre neste episódio é, portanto, intercalado por um processo de exploração de Ivan.

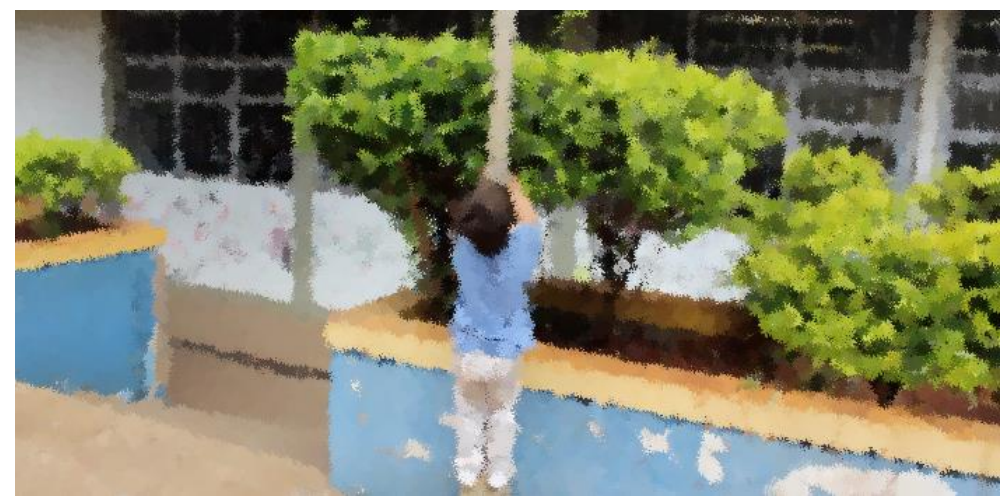

Figura 83. Ivan busca subir no poste.

O comportamento exploratório já foi foco de pesquisa na área da Psicologia do Desenvolvimento, embasando, através de experimentos naturalistas e descritivos, a relação entre comportamentos específicos e fases de desenvolvimento (Bijou \& Baer, 1965). Já foi utilizado para explicar o processo de desenvolvimento cognitivo, como estudado e detalhado por Piaget (Piaget, 1965; Piaget \& Inhelder, 1978), ou desempenhando papel central para o entendimento de ações e intencionalidade nos estudos sobre desenvolvimento de ações qualificadas na infância (Bruner, 1973), sendo a partir de então, considerado como fator inerente ao processo de aprendizagem humana (Gibson, 1988; Loveland, 1987). Aqui, consideraram-se para a definição e identificação da ação exploratória, os três elementos propostos nos estudos de Bruner (1973) quando ele discorre sobre o desenvolvimento da habilidade de manipulação de objeto no primeiro ano de vida: (1) intenção da ação (i.e., comportamento(s) que revelam o desígnio da ação); (2) o subsequente feedback (i.e., comportamentos que sinalizam a continuidade ou interrupção do processo); e, (3) o estabelecimento de padrões de comportamento (e.g., observar, tocar, executar movimento semelhante e etc.).

Neste episódio específico, esse processo inicia no momento em que Ivan começa a tentar subir no poste, imediatamente após a saída de Hugo. Ivan não presenciou o processo de escalada de Hugo, mas mesmo assim busca formas de executar a atividade a partir de suas próprias referências na 
exploração do objeto. Julga-se, ainda, pertinente informar que, ao longo da gravação, a pesquisadora pergunta para a monitora da sala, que se encontra o tempo todo nas imediações do pátio, se Ivan já escalara esse poste outras vezes. A monitora afirma que não, sendo a essa a primeira tentativa.

$\mathrm{Na}$ ausência do modelo e da mediação do par, Ivan não consegue achar os caminhos necessários para executar a atividade (escalada ao poste) conforme foi realizado por Hugo. Ele então, olha para o pátio, na mesma direção pela qual Hugo saiu. Essa busca pelo par também foi identificada nos episódios anteriores, com a diferença de que naqueles, o par esteve o tempo todo compartilhando o processo com Ivan e, neste caso, Hugo havia abandonado a cena.

Segundo Wallon (2007), as crianças entre dois a quatro anos vivenciam um momento em que o intercâmbio entre pares acontece preponderantemente através da imitação, pois configura-se na experiência em que a identificação com o outro é essencial para a elaboração da sua própria pessoa. Nos trabalhos de Lucena (2010), ao analisar o como as rotinas infantis se configuram na microcultura de grupos de crianças de dois anos, encontram-se evidências de que as "brincadeiras que as crianças criam giram em torno de temáticas relativamente simples: arrastar, montar, engatinhar; temáticas essas, na maioria das vezes, inspiradas nas próprias ações das crianças" (p. 143). Contudo, a autora destaca que é no processo de negociação de significados em que elas estão envolvidas, durante o desenrolar dessas temáticas, que a complexidade se mostra e é com ela que as inovações ocorrem, tanto do ponto de vista da brincadeira em si (na repetição da atividade e na inovação na nova experiência), quanto do ponto de vista dos comportamentos individuais das crianças, que desempenham grande esforço para coordenar as ações coletivas.

Corroborando com essa reflexão, entende-se que embora um par aleatório possa, através de seus movimentoslações, ter regulado o comportamento de Ivan, ter contribuído para o desenvolvimento da diferenciação entre o eu e o outro, ou ainda ter suscitado que essa criança manifestasse comportamentos exploratórios importantes para o seu desenvolvimento, é nas negociações para a estruturação da atividade compartilhada, nas significações dialógicas que o par oferece os elementos que auxiliam a criança com déficit intelectual a realizar a atividade de forma mais autônoma. No que tangencia a compreensão da criação de ZDP na relação com pares e considerando o que aponta Vygotsky (1994) sobre a criança imitar aquilo que está além do seu desenvolvimento, mas ainda circunscrito pelo seu entorno e pelas relações estabelecidas nele, entende-se que o par aleatório também pode oferecer situações para a criança com déficit intelectual avançar no processo de aprendizagem e desenvolvimento. Contudo, para essa criança pivô, os dados apontam que seria por meio da mediação direta e presente do par, através das contínuas negociações, construções e compartilhamento de significado, que os elementos para esse desenvolvimento se 
efetivariam, levando essa criança pivô a expressar movimentos, fazer ações ou realizar atividades de forma mais autônoma.

\section{Estudo de Caso Amanda}

$\mathrm{Na}$ análise das regulações de comportamento nas interações de Amanda com seus pares, identificou-se que Amanda estabeleceu mais frequentemente interações com Gustavo, Jéssica, Gabriela, Rafaela e Isabela, conforme pode-se verificar nas tabelas 16 e 17, abaixo. É imprescindível, contudo, destacar duas informações a respeito desses dados: o primeiro é que, das 29 crianças na sala de aula de Amanda, 11 não autorizaram os vídeo-registros sendo, portanto, necessário retirar dos materiais de análise todas as cenas que continham qualquer interação com esses pares, limitando o campo de interação na sua totalidade. Em segundo lugar, é preciso considerar que, em apenas $11 \%$ do tempo total de registro (vídeos), Amanda esteve desacompanhada de um adulto, sendo que em 155 das 165 situações (94\%) de regulações de comportamento com compartilhamento de objeto e atenção conjunta, foi o adulto quem posicionou a criança junto aos pares. Neste sentido, é preciso reconhecer que o estabelecimento de pares preferenciais para Amanda é perpassado constantemente pela mediação e intervenção direta do adulto.

Tabela 16. - Mapeamentos das interações com os pares em situações de regulação de comportamento com atenção conjunta iniciadas por Amanda.

\begin{tabular}{lccc}
\hline Pares envolvidos & Incidências de regulações & Total & Contexto \\
\hline \multirow{3}{*}{ Gustavo } & 7 & & Refeitório \\
& 1 & 14 & Sala de aula \\
& 4 & & Pátio \\
& 2 & & Ed. Física \\
Jéssica & 5 & & Refeitório \\
& 5 & 15 & Sala de aula \\
& 2 & & Educação Física \\
Gabriela & 3 & & Pátio \\
& 1 & & Sala de aula \\
& 3 & 11 & Refeitório \\
& 4 & & Pátio \\
Isabela & 2 & & Educação Física \\
& 5 & 11 & Sala de aula \\
& 1 & & Refeitório \\
Rafaela & 5 & 7 & Pátio \\
& 4 & & Sala de aula \\
Renata & 3 & & Pátio \\
& 2 & 4 & Sala de aula \\
& 1 & Ed. Física
\end{tabular}




$\begin{array}{lccc}\text { Miguel } & 2 & 4 & \text { Sala de aula } \\ \text { Pátio } \\ \text { Rodrigo } & 2 & & \text { Pátio } \\ & 2 & 3 & \text { Teatro } \\ & 1 & & \text { Teatro } \\ \text { Letícia } & 1 & & \text { Pátio } \\ & 2 & 4 & \text { Sala de aula } \\ \text { André } & 1 & & \text { Ed. Físico } \\ \text { Felipe } & 1 & 3 & \text { Refeitório } \\ \text { Raissa } & 2 & & \text { Pátio } \\ \text { José } & 2 & 2 & \text { Pátio } \\ \text { Pares de } & 2 & 2 & \text { Sala de aula } \\ \text { sala } & 1 & & \text { Ed. Física } \\ & 1 & 2 & \text { Pátio } \\ \end{array}$

Tabela 17. - Mapeamentos das interações de Amanda em situações de regulação de comportamento com atenção conjunta iniciadas pelos pares.

\begin{tabular}{|c|c|c|c|}
\hline Pares envolvidos & Incidências de regulações & Total & Contexto \\
\hline Gustavo & $\begin{array}{l}5 \\
1 \\
2 \\
3\end{array}$ & 11 & $\begin{array}{c}\text { Refeitório } \\
\text { Sala de aula } \\
\text { Pátio } \\
\text { Ed. Física }\end{array}$ \\
\hline Jéssica & $\begin{array}{l}7 \\
4 \\
3 \\
1\end{array}$ & 15 & $\begin{array}{c}\text { Refeitório } \\
\text { Pátio } \\
\text { Sala de aula } \\
\text { Sala de vídeo }\end{array}$ \\
\hline Gabriela & $\begin{array}{l}3 \\
3 \\
2 \\
2\end{array}$ & 11 & $\begin{array}{c}\text { Sala de aula } \\
\text { Refeitório } \\
\text { Pátio } \\
\text { Educação Física }\end{array}$ \\
\hline Isabela & $\begin{array}{l}7 \\
1 \\
3\end{array}$ & 11 & $\begin{array}{l}\text { Sala de aula } \\
\text { Refeitório } \\
\text { Pátio }\end{array}$ \\
\hline Rafaela & $\begin{array}{l}7 \\
3\end{array}$ & 10 & $\begin{array}{l}\text { Sala de aula } \\
\text { Pátio }\end{array}$ \\
\hline Renata & $\begin{array}{l}3 \\
2 \\
1\end{array}$ & 6 & $\begin{array}{l}\text { Sala de aula } \\
\text { Ed. Física } \\
\text { Pátio }\end{array}$ \\
\hline
\end{tabular}




\begin{tabular}{lccc} 
Miguel & 2 & 4 & $\begin{array}{c}\text { Sala de aula } \\
\text { Pátio }\end{array}$ \\
Rodrigo & 2 & & Pátio \\
& 1 & 2 & Sala de vídeo \\
& 1 & & $\begin{array}{c}\text { Teatro } \\
\text { Pátio } \\
\text { Letícia }\end{array}$ \\
& 1 & 4 & Sala de aula \\
André & 1 & & Ed. Físico \\
Fefipe & 1 & 2 & Sala de aula \\
Raissa & 1 & 2 & Pátio \\
José & 2 & 1 & Sala de aula \\
\hline
\end{tabular}

Ao longo das análises das regulações de comportamento, novamente a imitação aparece no centro das ações da criança pivô. No caso da Amanda, julga-se relevante destacar a particular situação em que a imitação é sustentada pela regulação do comportamento que não está relacionada à ação de um par específico, mas sim a uma açãolmovimento manifestado pelo grupo (o contágio emocional) (La Taille, Oliveira \& Dantas, 1992; Wallon, 1995; 2008). Tais situações se deram na sala de vídeo, no teatro, na sala de aula, no pátio e na aula de educação física, apreendidas em doze dos dezoito dias em que a pesquisadora registrou as interações de Amanda na instituição, contabilizando um total de quinze situações. No episódio abaixo, explora-se em detalhe o processo mencionado.

\section{Amanda em: "No embalo do berimbau"}

\section{Data: 17 de novembro de 2014, gravação (1) aos 20'15',}

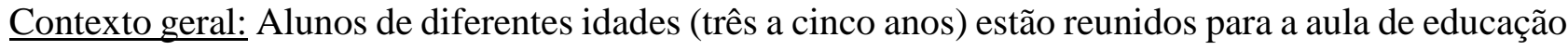
física que acontece na quadra da instituição. É a primeira vez que os alunos da turma de três anos estão tendo uma aula de capoeira. Os alunos são orientados pelas professoras a se organizarem em círculo e a esperarem pela sua vez de jogar. Amanda é colocada ao lado de duas crianças mais velhas e a educadora se mantém atrás de Amanda (aproximadamente a dois metros), ao longo de toda a atividade. A professora define o ritmo da música e o instrumento principal é tocado por um monitor. Algumas crianças do grupo de cinco anos também tocam berimbau (em instrumentos de menor tamanho), enquanto outras cantam e batem palmas ao ritmo do som produzido.

Descrição da cena: Amanda mantém-se parada por alguns instantes. Ela olha para as diferentes crianças, olha para a criança tocando o berimbau que está ao seu lado esquerdo, olha para as mãos 
do colega ao tocar o berimbau, olha para as crianças que jogam capoeira no meio da roda, olha para o colega ao seu lado direito (enquanto ela bate palmas). Amanda começa a bater palmas. Amanda acompanha as palmas e o ritmo da música, olha para o lado, aponta para o instrumento (berimbau) tocado pela criança ao seu lado esquerdo e retorna seu olhar para as crianças que estão na roda. Volta a bater palmas. Amanda olha para a criança a sua esquerda (ela toca o berimbau $e$ mexe com os pés), e imediatamente começa a bater os pezinhos no chão. Nesse momento, a professora chama por seu nome e Amanda caminha em direção ao centro da roda. Chegando ao centro, mesmo sem o comando verbal da professora, Amanda abaixa-se assumindo a mesma postura que os colegas anteriores fizeram. A professora segura na mão de uma colega (Isabela) e na mão de Amanda, auxiliando no equilíbrio das duas crianças. Isabela passa o pé sobre a cabeça de Amanda, que se encontra ainda abaixada. Amanda se levanta e Isabela assume a postura abaixada. Ainda, segurando na mão da professora. Amanda passa sua perna direita sobre a cabeça de Isabela, completando o movimento da dança. Ambas crianças retornam para seus lugares na roda. Amanda volta a bater palmas.

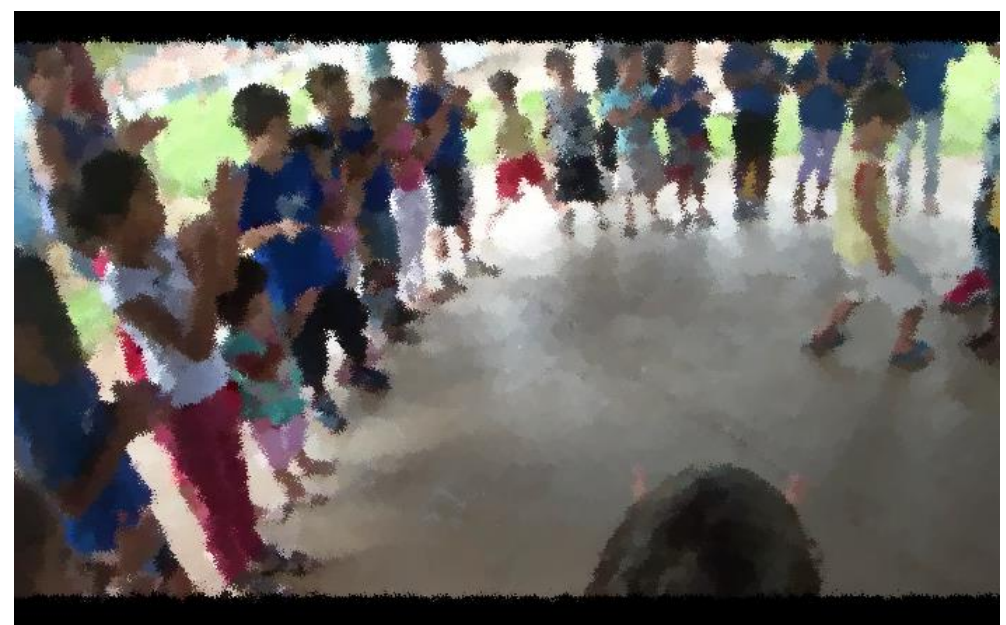

Figura 84. Amanda (identificada com a flecha branca) bate palmas e olha para os alunos jogando capoeira.

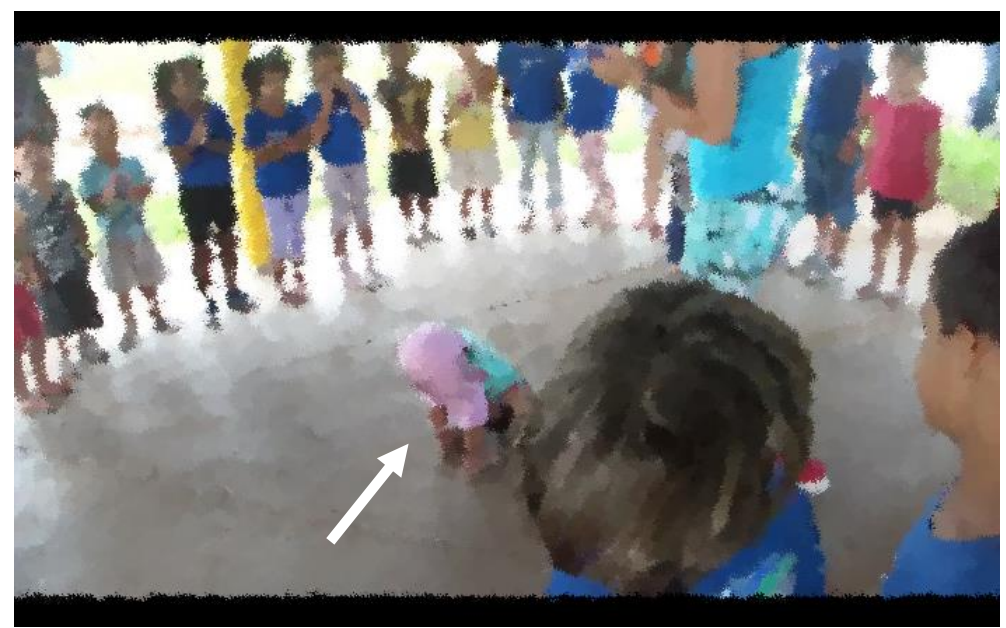

Figura 85. Amanda abaixa-se, colocando-se em posição na roda de capoeira. 


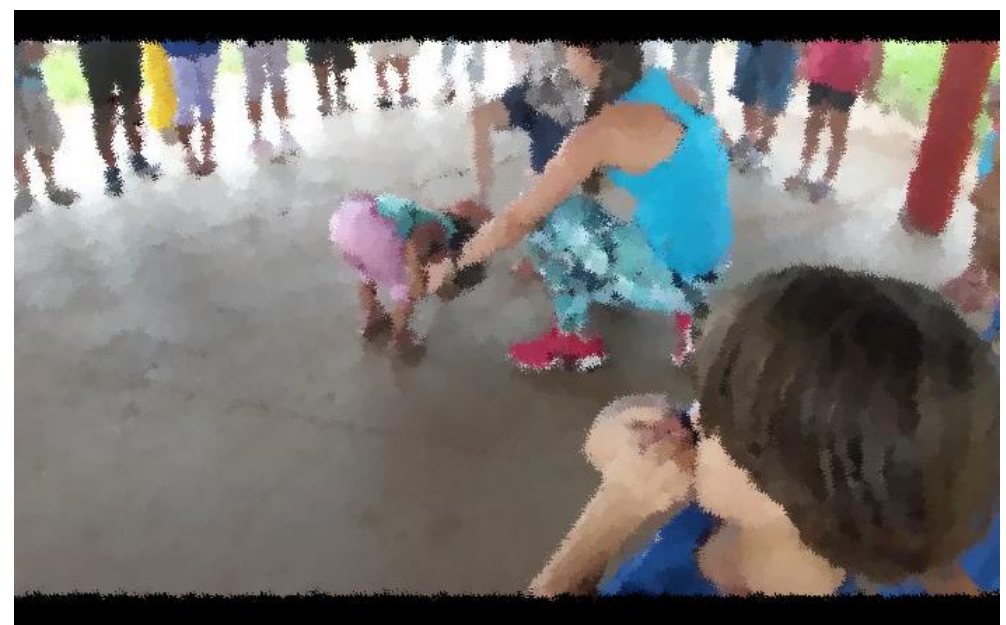

Figura 86. Com a ajuda da professora, o par passa o pé sobre a cabeça de Amanda.

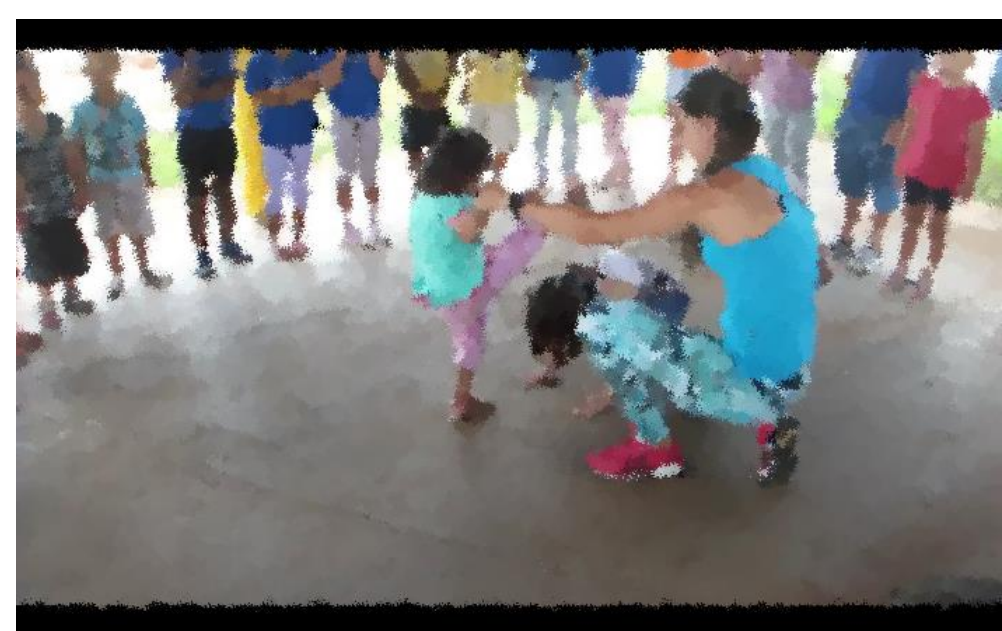

Figura 87. Ao som do berimbau e com colaboração da professora, Amanda faz o passo de capoeira, passando a perna sobre a cabeça da colega.

A sequência dos comportamentos expressos por Amanda (olhando ao seu entorno), observando o que está acontecendo e gradativamente incorporando movimentos dos pares (bater palmas, bater o pezinho no chão) no seu próprio repertório, caracteriza o mesmo processo identificado nos casos Inácio e Ivan - contemplação. Contudo, no caso da Amanda, chama-se a atenção para o como esse processo vai se transformando. Ele ocorre em paralelo a uma imitação simultânea cadenciada e rítmica, dos movimentos expressos pelos demais componentes do grupo, todos regidos por estímulos sonoros específicos (a música cantada e o som do instrumento musical) e uma estrutura (em roda e com participação ao centro por turnos) de atividade que prevê um 'ritual' (comportamentos a serem executados de forma específica, em um ritmo próprio). Identifica-se, aqui, um processo de contágio emocional (Wallon, 1995; 2008), em que a atmosfera emocional domina a concentração dos membros do grupo dela participantes. 
Para Wallon, o contágio emocional, através do seu potencial mobilizador, evidencia a relevância e a força da emoção para o desenvolvimento na evolução da espécie humana, uma vez que,

“A propagação 'epidérmica' das emoções, ao provocar um estado de comunhão e de uníssono, pode levar a esforços e intenções em torno de um objetivo comum. Permitiria, assim, relações de solidariedade quando a cooperação não fosse possível por deficiência de meios intelectuais ou por falta de consenso conceitual, contribuindo, portanto, para a constituição de um grupo e para as realizações coletivas" (Galvão, 2001, p. 15).

Assim, a emoção assume uma função social e a atividade emocional seria simultaneamente sóciobiológica, ajudando na constituição de uma vida em sociedade. Vygotsky não remete em seus estudos nenhuma atenção a esse fenômenolprocesso específico (contágio). Todavia, considerando as convergências entre Wallon e Vygotsky na ênfase dos aspectos sociais e emocionais presentes no desenvolvimento da criança e na condição de interdependência entre o desenvolvimento do indivíduo e da sociedade (Vasconcelos \& Valsiner, 1995), analisa-se que esse estado de diluição do eu no coletivo do grupo possa ser também, dentro de uma perspectiva histórico-cultural, um processo fundamental para que a criança transforme o interpsíquico em intrapsíquico, mesmo que os limites entre esses dois níveis estejam ainda indiferenciados para ela.

Neste sentido, destaca-se a relevância de se analisar outro importante aspecto revelado pelos dados - ao papel do outro na constituição e na consciência do eu, ou seja, a contraditória e complementar dinâmica no processo de identificaçãoldiferenciação do Eu\outro (Wallon, 1986). A partir desse aspecto, o episódio apresentado nos oferece material para discutir como as situações de contágio emocional vivenciadas por Amanda permitem que os jogos de alternância, nos quais essa criança ora é autora em relação ao outro, ora é objeto do outro, auxiliam-na na diferenciação de si perante as dos outros. Para jogar a capoeira, Amanda precisou compreender que existe uma dinâmica em que papeis diferentes são representados em um ritmo e uma cadência de eventos. Para além, ela precisa situar-se nesses papéis e acompanhar, através da observação das ações dos pares, como suas próprias ações se situam.

Embora Wallon (1986) afirme que situações como essa não signifiquem que haja a afirmação de um ponto de vista pessoal, ou seja, “o Eu não assumiu, ainda, diante do outro, esta espécie de estabilidade e constância que nos parece indispensável à consciência de si, que parece ser constitutiva da pessoa" (p.162), entende-se que o efeito "dinamogênico, excitante” que a situação oferece 
impulsiona a tomada do Outro ora como referência (e pela identificação há a incorporação dos comportamentos observados pela imitação), ora como contraponto (e pela diferenciação a orientação para a manifestação de seus próprios comportamentos dentro de uma atividade conjunta).

É importante ressaltar que, diferente de Inácio e Ivan, para Amanda, processo de contágio similar ao descrito acima ocorreu em todas as situações em que houve atividades que combinaram música e gesto (e.g., interpretando uma música na sala de aula, cantando e imitando os gestos dos personagens de um filme, acompanhando uma música cantada pela professora) no seu cotidiano institucional.

Na continuação do episódio, Amanda é chamada (a professora fala seu nome) para jogar e imediatamente segue em direção ao centro da roda. Sem a prévia instrução verbal do adulto, ela se posiciona de acordo com os comportamentos do ritual do jogo de capoeira expressos anteriormente pelos pares. Em uma simulação da situação desejada, Amanda mostra uma forma concreta de representação através da (re)apresentação de atitude postural, caracterizando, além da imitação simultânea, (Nadel, 1986 citado por Galvão, 2001), a modelação do corpo da criança pelo outro (no caso a educadora que a apoia e a ajuda a fazer os movimentos). Como já mencionado, tal processo é apontado como um aspecto indicativo da transição entre o mimetismo, a imitação diferida e, posteriormente, a representação, e evidencia a construção de esquemas de mediação semiótica - base para o processo de representação (Galvão, 2008). Ainda, considera-se na ação da criança, a espontaneidade e iniciativa ao assumir a postura específica e imitar o processo previamente observado, elementos que abrem espaço para se especular que, embora essa tenha sido a primeira vez que Amanda tenha tido contato com a capoeira ${ }^{34}$, os elementos que conferem especificidade ao ritual cultural estejam sendo incorporados, como em uma "espécie de foto-imagem em que o modelo se imprime no corpo do imitador" (Galvão, 2001, p.26).

Na sequência, julga-se importante discutir sobre o papel do professor e do par nesse episódio de interação em que atuam sustentando fisicamente o gesto imitativo e oferecendo o feedback verbal e postural que sinalizam engajamento na atividade e criam, com os demais membros desse campo social, um processo comunicativo que mantêm o ritual estabelecido (jogo de capoeira). Não há em nenhum momento uma orientação específica para Amanda ou um tratamento diferenciado ao longo do jogo, levando à conclusão de que os gestoslcomportamentos manifestados pela criança pivô estejam diretamente relacionados com os processos já descritos anteriormente. Contudo, a ausência da orientação específica do adulto para com a criança com déficit intelectual levanta a hipótese de que, possivelmente, a imitação por contágio tenha sido significada pela professora como evidência

\footnotetext{
34 Informações provenientes do diário de campo confirmam essa afirmação.
} 
de que Amanda sabe o que é que deve ser feito e que é igualmente partícipe nas atividades do contexto escolar em meio ao grupo. Essa hipótese justificaria a crençalafirmação da professora, revelada na entrevista com ela, de que Amanda não precisa de um plano pedagógico específico. Abaixo um trecho do diário de campo que confirma as suspeitas levantadas ao longo das análises das regulações de comportamento:

Informações do diário de campo - Data: 17 de novembro de 2014

(...) foi a primeira vez que eu vi Amanda junto com crianças bem mais velhas. Amanda participou o tempo todo da atividade e me recordei da entrevista com Angélica (a professora regente de Amanda), quando ela fala que Amanda faz tudo igual aos colegas e, por isso, não vê necessidade de fazer um planejamento individualizado para atender às demandas dela. Fico me perguntando se o fato dela fazer 'tudo igual aos outros' seja sinal que ela não tem demandas especificas para a aprendizagem ou se isso é o que faz a professora enxergá-la como participante do grupo.

Tal hipótese remete à discussão presente nos trabalhos iniciais de Vygotsky na defectologia, em que ele afirmava que "todas as deficiências corporais - seja a cegueira, surdo-mudez ou um retardo mental congênito - afetavam antes de tudo as relações sociais das crianças e não suas interações diretas com o ambiente físico" (Van Der Veer \& Valsiner, 2014, p. 74). Tal afirmação abre espaço para a reflexão sobre as práticas pedagógicas adotadas dentro dos contextos de educação infantil junto à criança com deficiência.

No que se refere à ZDP, o episódio oferece possibilidades para a discussão de como a regulação de comportamento advinda do coletivo do grupo, ao invés do par específico, também estrutura o contexto para a aprendizagem da criança e, no caso, da criança com déficit intelectual. Isso ressalta

o papel fundamental da emoção no estabelecimento das interações, já sistematicamente explicitado tanto nas obras de Wallon, quanto de Vygotsky. Contudo, este episódio oferece espaço para que se olhe para a ZDP a partir da perspectiva da coletividade, em que "a ZPD não é exclusivamente ou primariamente uma relação diádica e que a chave para a ZPD seja o fato de pessoas estarem fazendo coisas juntas" (Holzman, 2010, p. 29). A imitação advinda do contágio explicita a função do comportamento coletivo como forma de cooperação ou atividade cooperativa que caracteriza o nível interpsicológico do desenvolvimento (Vygotsky, 2004b).

\subsubsection{Reflexões sobre a fase II - Mapeamento e microgenética das regulações de comportamento.}

Nesta fase II de análise dos dados, o objetivo foi buscar compreender como os conteúdos das regulações e corregulações de comportamento podem estar relacionadas à construção das Zonas de Desenvolvimento Proximal entre pares de mesma idade junto à criança com déficit intelectual. 
Em primeiro lugar, destaca-se que a análise das interações a partir das regulações de comportamento mostrou-se interessante para o presente estudo, ao revelar aspectos processuais (e.g., direção e fluxo de troca de informações, tipo de recurso utilizado e dinâmicas de comunicação) deste fenômeno. Trata-se de uma abordagem que vem sendo desenvolvida (Carvalho, 1989; Carvalho, Império-Hamburger \& Pedrosa, 1996; Pedrosa \& Carvalho, 1995) e foi já empregada em estudos com diferentes perspectivas (Carvalho \& Pedrosa, 2002; Lucena, 2010; Moura, 2012; Ferreira, Mäkinen \& Amorim, 2016), mas que até então não havia sido aplicada para investigar empiricamente a possibilidade da identificação dos processos que constituem o fenômeno conceitual da ZPD. Tampouco, fora utilizada para a análise de interações entre pares quando, em meio a estes, encontrase uma criança com déficit intelectual. Ainda, neste trabalho, o olhar para a regulação e a corregulação de comportamento permitiu que o foco de atenção da investigação residisse no processo da interação e não apenas no produtoไresultados dela, corroborando para a estruturação de novas formas (recursos e caminhos) para se investigar os processos de desenvolvimento humano e constituindo uma nova perspectiva para se entender a constituição da ZPD.

Ao longo desse processo de análise, identificou-se que a atenção conjunta e o compartilhamento de objetos representam elementos fundamentais, entendendo que, em partes, a composição estabelecida pela relação direta entre criança pivô, o objetolsituação e o par, é o que vai permitir a possibilidade da reciprocidade na troca de informações no campo de interação e foi neste contexto de possibilidade de reciprocidade (corregulações) que se encontraram as mais eficientes mediações dos pares. Nos episódios analisados, essa mediação do par, independente da sua estrutura (assumida de forma diferente nos três casos), possibilitou a mudança nos comportamentoslações da criança pivô no sentido da realização (mais ou menos completa) de uma atividade específica em curso (e.g., fazer o brinquedo deslizar na plataforma de madeira, caso Ivan), a (co)construção da atividade compartilhada (e.g., o faz de conta de Inácio com Lorena), ou ainda, o engajamento na dinâmica grupal durante a realização de uma atividade coletiva (e.g., a participação ativa de Amanda no jogo de capoeira). Dessa forma, para além de corroborar com resultados de estudos anteriores em que se identifica a competência de crianças, desde tenra idade, para atuar ativamente na constituição do outro (Amorim, 2008; Eydam \& Nurmsoo, 2014; Reddy, 2012; Selby \& Bradley 2003; Trevarthen 2005), os resultados deste estudo destacam o aspecto mediacional da ação do par de idade.

Particular ênfase cabe ao papel dos pares preferenciais que, na possibilidade da abreviação dos processos comunicativos (Carvalho \& Rubiano, 2004; Costa \& Amorim, 2010), identificaram alguns dos elementos necessários para a participação da criança pivô no momento da ação em curso e atuaram no sentido de viabilizar essa participação. Tal processo é aqui entendido enquanto manifestação de uma possível intenção por parte do par na participação da criança pivô na atividade 
compartilhada, o que caracterizaria um elemento inédito na análise das interações entre pares no âmbito da educação especial.

Os processos de mediação, neste trabalho, são interpretados como uma significativa evidência de que os pares de idade possam criar, na interação com a criança com déficit intelectual, Zonas de Desenvolvimento Proximal, uma vez considerada a principal definição de ZPD no trabalho de Vygotsky como:

"A distância entre o nível de desenvolvimento real, que se costuma determinar através da solução independente de problemas, e o nível de desenvolvimento potencial, determinado através da solução de problemas sob a orientação de um adulto ou em colaboração com companheiros mais capazes" (Vygotsky, 2007, p. 97),

Nesses processos de mediação, conforme os resultados apresentados, se desenvolveram-se situações em que a ação dos pares de idade possibilitou que as crianças com déficit intelectual realizassem atividades que sozinhas elas não realizariam (encaminhando para a solução de problemas).

Nas regulações de comportamento sem a atenção conjunta ou compartilhamento de objetos, embora se identifique a imprevisibilidade do campo de interação indicando que pares aleatórios possam regular os comportamentos da criança pivô, as mudanças efetivamente impulsionadas pelo par ocorreram no nível postural latitudinal; não estruturaram ou ofereceram os recursos necessários para que a criança pivô executasse sozinha a atividade inédita em si. Neste sentido, a criança pivô assumiu posturas ou manifestou gestos\movimentos em direção à completude de uma atividade específica (e.g., escalar o muro ou subir no poste de luz), ação que sozinha talvez não fizesse, mas não efetivou a atividade como nos casos onde o par, pelas corregulações de comportamentos, sustentou esse processo.

É ainda imprescindível relacionar essa ação do par ao conteúdo das ações no processo de interação. E, a análise microgenética nesta fase II revelou a imitação como sendo o centro desse processo. A imitação tem sido estudada e debatida empírica e teoricamente de forma exaustiva por quase cem anos, a partir de diferentes perspectivas teóricas, com metodologias de investigação diferenciadas (Moura \& Ribas, 2002). Em todos os diferentes estudos, reconhece-se a relevância de tal processo para o desenvolvimento humano, seja enquanto um instinto biológico, produto de um processo de desenvolvimento ou resultados de associações (Moura \& Ribas, 2002). Para Vygotsky, segundo Valsiner e Van der Veer (1993), a imitação está intrinsicamente ligada à função e à formação da ZPD, não só pela relação direta entre imitação e o desenvolvimento da representação e da 
linguagem, mas no que antecede a tudo isso - na diferenciação do eu e o outro na construção compartilhada. Tal perspectiva também é encontrada nos estudos e teoria de Wallon, para quem a imitação, enquanto um processo utilizado pela criança como ferramenta para unir as ações motoras às mentais, concretiza-se como uma capacidade de construção e transformação do espaço social e está diretamente relacionada à origem dos processos de representação (Vasconcelos \& Valsiner, 1995).

Neste estudo, corrobora-se teoricamente com os autores supracitados e, neste sentido de raciocínio, reflete-se que nos resultados apresentados aqui, de forma ampla e geral, a imitação identificada em todos os três casos, mesmo que constituída de forma única e diferente (algo esperado pela singularidade do processo de desenvolvimento), possibilitou que essas crianças com déficit intelectual fossem impulsionadas a manifestar posturaslatitudes inéditas elou a desenvolver, na esfera micro de cada episódio, as habilidades necessárias para realizar atividades específicas com os pares. Contudo, a essas mudanças não se atribui apenas o conteúdo (imitação), mas à junção desse com a ação mediacional do par que, por meio de gestos, fala e posturas (e.g., espera pela resposta, aproximação ou distanciamento do objeto no momento da ação), vai permitindolefetivando a participação da criança pivô na atividade. É nessa situação que, de fato, observaram-se possibilidades para a criança pivô gradativamente discriminar sua própria ação da de seus parceiros.

A imitação foi sendo construída de diferentes formas nos diversos episódios nos três casos, resultado a que se atribui às diferenças no contexto de cada criança, além de vivências anteriores. A ação do adulto, a organização espacial, ou até mesmo o tipo de atividade desenvolvida foram elementos importantes para se compreender o como as interações foram (ou não) oportunizadas e, também, o como a imitação foi estabelecida (e.g., via um processo anterior de contemplação, a partir do contágio emocional nas atividades coletivas, com ou sem um modelo e etc.). Por um lado, ao analisar-se a experiência de Inácio, pode-se levantar a hipótese de que a menor participação do adulto possa ter permitido maior autonomia na escolha dos pares e, no ambiente de sala de aula, a composição do ambiente e o tipo de atividade combinadamente viabilizaram uma interação que privilegiou a imitação por meio da contemplação da ação do par. Por outro lado, pode-se especular que, para Amanda, a constante presença do adulto e uma organização do espaço que limita o contato par-a-par, tenha resultado em um número menor de regulações de comportamento, mesmo tendo mais tempo de registro dentre os três casos, ou ainda, que seja em decorrência desse particular contexto institucional - em que Amanda é bastante assistida - que os momentos de atividade coletiva tenham sido tão significativos para ela, justificando a relevância das imitações por contágio emocional dentro do universo dos dados analisados. 
Em suma, as regulações e as corregulações de comportamento foram, portanto, imprescindíveis para a compreensão da direção e do fluxo da troca de informações que constituíram o processo interativo e que contextualizam e explicam o conteúdo (e.g., contemplação, imitação com modelo e etc.) que se encontra em construção na interação entre os pares. A análise desse conteúdo que acontece imediatamente após, revela o tipo de aprendizagem que está sendo construída (e.g., ajustar a força do arremesso do saco de gelo no escorregador, ou executar no ritmo da música os movimentos do jogo de capoeira) e o papel de cada membro do campo social nessa construção.

Cabe destacar, por fim, a singularidade do processo de interação. Embora se tenham identificado pares preferenciais em todos os casos, a imitação tenha sido o centro das ações para todas as crianças e, mesmo considerando que este estudo tenha sido realizado dentro de contextos institucionais cujas regras de condutas sociais são padronizadas e bem definidas, a maneira como esses elementos foram constituídos na experiência interacional cotidiana foi individual, singular e única, da mesma forma que se dá o desenvolvimento humano (Rossetti-Ferreira, Amorim \& Silva, 2004). A análise caso-a-caso dos episódios de regulação e corregulações de comportamento permitiu que fossem identificados aspectos específicos da forma como as crianças estabeleceram seus processos interacionais e a subjetividade, enquanto produção cultural histórica e social (GonzálezRey, 2016), vai se tornando explícita nos modos de corregulações na medida em que são construídos diferentes sentidos para elementos semelhantes. A reflexão que surge a partir da constatação dessa singularidade é que seja a vivência (Perezhivanie), enquanto condição social de desenvolvimento, o elemento que delimita o percurso no processo de constituição do sujeito (desenvolvimento).

$\mathrm{Na}$ continuação do processo investigativo, na subsequente fase III de análise dos dados, julgou-se imprescindível abordá-los pela perspectiva da temporalidade, ou seja, apreender sobre os processos interativos e suas possíveis transformações, ao longo do tempo. Dentro dessa perspectiva, o olhar investigativo recaiu sobre os diferentes tipos de aprendizagem que, possivelmente estariam circunscritos nas corregulações de comportamento e nos elementos específicos que estruturaram o processo interativo ao longo do período total de coleta de dados. Buscou-se identificar se houve diferenças nos tipos de aprendizagem e se havia nesses processos indícios para a reflexão sobre a ZPD. Ainda, buscou-se encontrar evidências empíricas que revelassem os possíveis elementos que foram transformados na interação de pares ao longo do ano, interligando a aprendizagem pela ação do outro em uma temporalidade específica e possivelmente revelando aspectos da vivência desses sujeitos. 


\subsubsection{Resultados referentes a fase III - Análise microgenética das interações ao longo do tempo}

$\mathrm{Na}$ terceira fase, o foco das análises recaiu sobre as transformações na forma como as interações de pares se constituíram ao longo do ano. Particular atenção foi dada à identificação de processos de aprendizagem através das corregulações de comportamento e à busca por indícios que permitissem a reflexão sobre a ZPD na relação de pares ao longo do tempo. Dessa forma, e considerando os resultados das análises anteriores que indicaram que as corregulações de comportamento com atenção conjunta ou compartilhamento de objeto são situações privilegiadas para as interações de pares, a microgenética foi aplicada exclusivamente nesses episódios.

A seleção dos dados para a fase III de análise, conforme descrito no capítulo de metodologia, teve origem a partir do mapeamento das situações de regulação de comportamento. Ainda, respeitouse um recorte temporal representativo de três momentos da coleta de dados: início, meio e final. Para cada participante, esses três momentos representaram meses e quantidades de episódios diferentes, conforme mostra a tabela 18 abaixo.

Tabela 18. Material selecionado para a terceira fase de análise de dados - Quantitativo de episódios de corregulações de comportamento com atenção conjunta ou compartilhamento de objeto.

\begin{tabular}{|c|c|c|c|}
\hline Estudo de caso & Início & Meio & Final \\
\hline Inácio & $\begin{array}{l}\text { Março - } 5 \text { episódios, } \\
2 \text { dias - 57'50'’ }(0,08)^{*}\end{array}$ & $\begin{array}{l}\text { Agosto - } 9 \text { episódios, } \\
4 \text { dias }-67^{\prime} 11^{\prime \prime}(0,13)^{*}\end{array}$ & $\begin{array}{l}\text { Dezembro - } 4 \text { episódios, } \\
1 \text { dia }-30^{\prime} 01^{\prime},(0,13)^{*}\end{array}$ \\
\hline Ivan & $\begin{array}{l}\text { Março - } 3 \text { episódios, } \\
2 \text { dias }-44^{\prime} 53^{\prime \prime}(0,6)^{*}\end{array}$ & $\begin{array}{l}\text { Agosto - } 17 \text { episódios, } \\
3 \text { dias }-57^{\prime} 16^{\prime \prime}(0,29)^{*}\end{array}$ & $\begin{array}{l}\text { Dezembro - } 10 \text { episódios, } \\
2 \text { dias - 54'50', }(0,18)^{*}\end{array}$ \\
\hline Amanda & $\begin{array}{l}\text { Maio - } 16 \text { episódios, } \\
3 \text { dias }-187^{\prime} 50^{\prime \prime}(0,08)^{*}\end{array}$ & $\begin{array}{l}\text { Setembro - } 25 \text { episódios, } \\
4 \text { dias }-180^{\prime} 47^{\prime \prime}(0,13)^{*}\end{array}$ & $\begin{array}{l}\text { Dezembro - } 8 \text { episódios, } \\
1 \text { dia }-29^{\prime}(0,27)^{*}\end{array}$ \\
\hline
\end{tabular}

*Nota: Valores extraídos da divisão direta entre o número de episódios pelo tempo total de registro do mês de referência.

Na sequência apresentaremos caso a caso como esses episódios foram analisados, ressaltando dois aspectos fundamentais para a conclusão dos objetivos propostos nesse trabalho: (1) as diferentes aprendizagens nos processos de interação; e, (2) as transformações nas características das interações de pares ao longo do tempo para cada criança.

\section{Estudo de caso Inácio}

No mês de março, as corregulações de comportamento com atenção conjunta ou compartilhamento de objeto aconteceram para Inácio circunscritas em duas situações: a primeira, na 
atividade de contação de história, em meio a um processo de imitação de gestos relacionados a música cantada coletivamente pelas crianças e professoras; e a segunda, em meio a atividade orientada pela professora em sala de aula, na interação com uma colega específica e mediada pela presença e ações da monitora da turma.

Em ambas situações, as aprendizagens constituídas na interação de pares possibilitaram à criança pivô construir seu próprio repertório de comportamentos frente às demandas desse meio social, através das ações dos pares. Abaixo, segue a apresentação dos dois episódios.

\section{Inácio em: "Era uma casa muito engraçada, não tinha teto, não tinha nada..."}

Data: 20 de março de 2014, gravação n. 1 aos 5'40',

Contexto geral: As quatro turmas de 1 período (crianças de três a quatro anos) estão juntas para o primeiro momento de contação de história do ano. Tal atividade é uma novidade para muitas crianças, dentre elas Inácio. Inácio está sentado perto de Pedro Augusto e de demais crianças derivadas de diferentes salas de aula. As professoras estão sentadas em diferentes cantos da sala e revezam a condução da atividade. Neste momento específico em que o episódio ocorre, as crianças estão cantando músicas, enquanto o teatro que acompanha a história que será contada é preparado.

Descrição do episódio: Pedro Augusto estica seu braço direito e cutuca as costas da criança a sua frente. Inácio olha para o colega. Pedro Augusto cutuca mais uma vez o colega Miguel que, por sua vez, vira e sorri. Inácio olha para ambas crianças. Inácio cutuca o colega a sua frente, mas nada acontece. Inácio olha para Pedro Augusto. Pedro Augusto pega na mão de Inácio e cutuca o colega a sua frente. O colega vira as costas e sorri. Pedro Augusto segura a mão de Inácio e olha para ele (expressão facial não visível). Inácio recolhe a mão e volta a olhar para frente. As crianças, incluindo Inácio, cantam e fazem gestos seguindo a música que está sendo cantada. Inácio imita alguns gestos, olha para os colegas ao seu redor, olha para a professora a sua frente, movimenta os lábios num movimento de canto e gesticula com as mãos os mesmos gestos das demais crianças. Pedro Augusto vira em direção a Inácio, estica seu braço e toca seu ombro. Inácio olha para o colega e segura seu braço. Pedro Augusto volta a olhar para frente. Ele se levanta e começa a bater palmas no ritmo da música. Inácio olha para o colega, estica seu braço e toca sua perna. Pedro Augusto vira em direção a Inácio e se senta no chão. Inácio levanta e começa a bater palma no ritmo da música. Pedro Augusto olha atentamente para o colega e sorri. Inácio volta a sentar-se no chão e ambos olham para frente. 


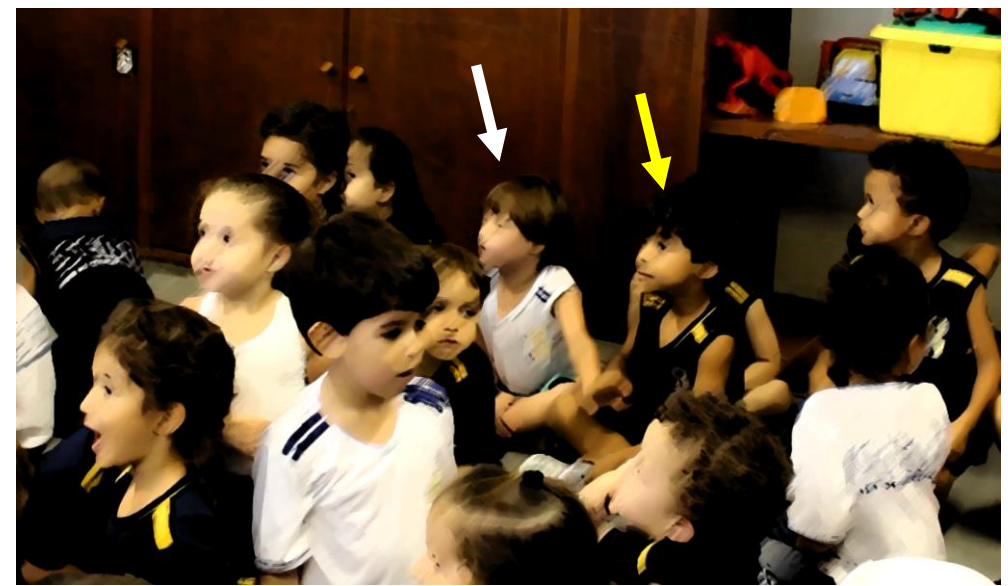

Figura 88. Pedro Augusto (flecha amarela) segura a mão de Inácio (flecha branca)

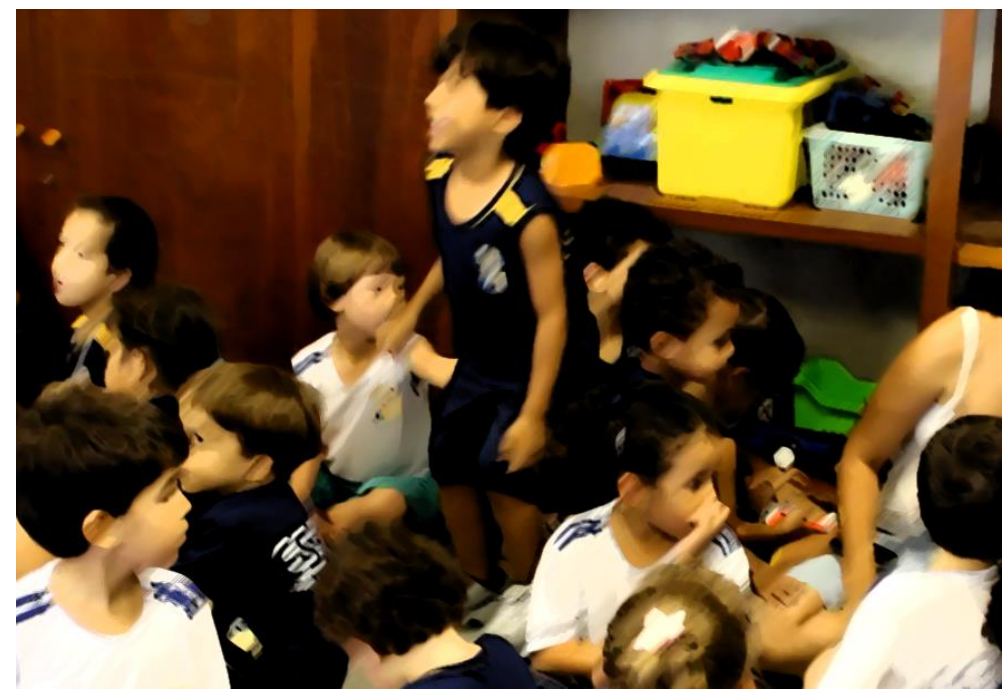

Figura 89. Pedro Augusto levanta e Inácio toca sua perna, chamando a atenção do colega.

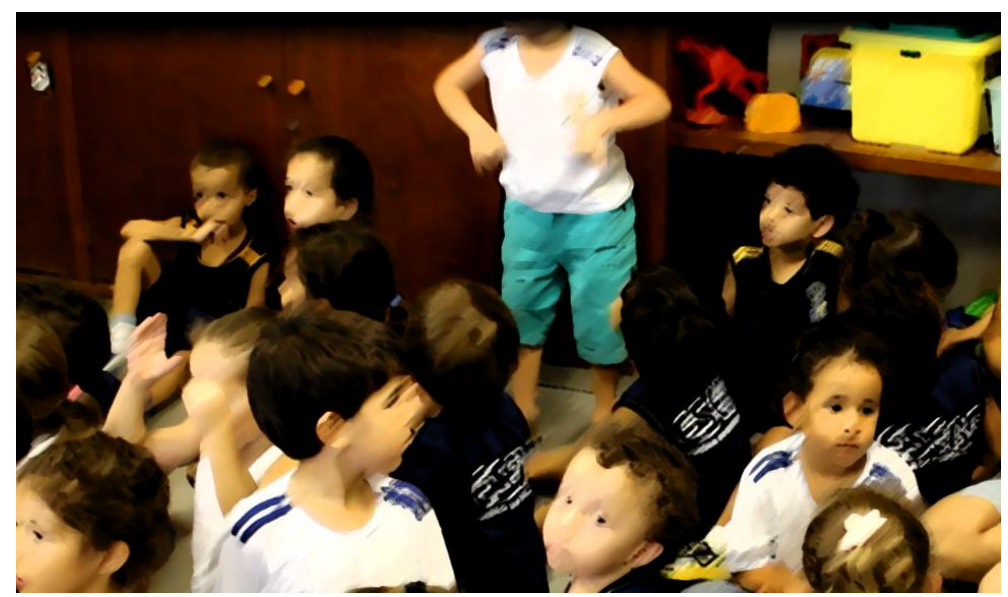

Figura 90. Inácio levanta e Pedro Augusto olha para o colega.

No episódio "Era uma casa muito engraçada, não tinha teto, não tinha nada", Inácio estabelece uma interação com corregulações de comportamento com o par Pedro Augusto, membro do mesmo grupo de alunos. Esse processo está circunscrito em um momento de intenso contágio 
emocional (Wallon, 1995; 2008), em que as crianças de diferentes turmas estão cantando e interpretando, com gestos guiados, as músicas conduzidas pelas professoras. Em meio a processos de mimetismo dos gestos das demais crianças, das professoras e também das monitoras de turma, Pedro Augusto chama a atenção de Inácio ao cutucar Miguel. A partir de então, Inácio o imita na sua ação de cutucar o colega. Suspeita-se que o que tenha chamado a atenção de Inácio seja o fato de Miguel ter virado e sorrido quando cutucado por Pedro Augusto. Independente do fator motivacional, Inácio se engaja em um processo de imitação desse gesto específico e também cutuca Miguel, contudo sem efeito semelhante. Na corregulação subsequente, Pedro Augusto que observa Inácio ao realizar a ação, segura sua mão e executa novamente o gesto de cutucar utilizando os dedos de Inácio como instrumento no processo, agora resultando no efeito do sorriso de Miguel.

Esse micro recorte no processo de corregulações de comportamento abre espaço para diferentes discussões sobre a ação do par na relação com a criança pivô como, por exemplo, a possível aprendizagem no uso do corpo como instrumento para ação, que aqui vai viabilizar que Inácio experimente a pressão, a força, a velocidade ou até mesmo a intensidade do gesto para provocar o resultado esperado (fazer com que o colega se vire e sorria); ou ainda, a intencionalidade nas ações do par para o auxílio na realização das atividades da criança pivô que, mediante a constatação do seu "fracasso" no chamar atenção de Miguel e, no reconhecimento de si, como alguém que consegue executar a ação, resolve intervir e fazer o movimento conjunto com Inácio.

No decorrer do episódio, a intervenção de Pedro Augusto desencadeia outros processos imitativos subsequentes (levantar-se e bater palmas), mantendo a atenção de Inácio e criando uma díade dentro do micro contexto da atividade em grupo que permitirá que, juntos, eles construam um jeito singular de estar naquele lugar $\backslash$ contexto, compartilhando significados e diferenciando-se dos demais colegas da sala, que se organizam de acordo com a estrutura de atividade proposta pelos adultos (professoras e monitoras de turma).

Nesse sentido, talvez a maior contribuição desse episódio de interação para o processo de desenvolvimento de Inácio esteja, neste momento relacionada, com o processo de estabelecimento de parcerias dentro desse campo social, em que a reprodução da ação do parceiro é considerada a forma prioritária de intercâmbio entre as crianças e a organização do seu processo de construção da brincadeira (Lucena, 2010). A participação ou a construção de brincadeiras (que possivelmente se transformam em rotinas culturais) proporcionam a segurança e o entendimento do pertencimento a um grupo e criam possíveis interlocutores privilegiados, descritos por Bruner (1983) como aqueles que significam as ações da criança e auxiliam-na no refinamento do seu repertório comunicativo. Esse processo é particularmente importante se considerado o fato de as crianças estarem vivenciando essa atividade juntas pela primeira vez, na sua segunda semana de aula. 
O segundo episódio vai ilustrar as corregulações de comportamento nas situações de atividade orientada pela professora na sala de aula, em que a identificação com o par acontece primeiramente através da posse de objetos e a posteriori, pela imitação do comportamento.

\section{Inácio em: "É seu, é meu, é nosso"}

\section{Data: 27 de março, gravação n. 2 aos 6'38' e gravação n.3 aos 2'33"'}

Contexto Geral: As crianças estão trabalhando com massa de modelar em uma atividade orientada pela professora. Inácio está sentado perto de Alice e Rebeca. Cada criança tem seu espaço de trabalho demarcado por uma folha de sulfite colorida, um pedaço de massa de modelar, dois palitos e duas tampinhas de garrafa PET que servem de molde para a massinha. As crianças têm a liberdade de modelar o que quiserem, mas a professora e a monitora as estimulam oferecendo diferentes ideias (bola, bolo, minhoca, etc). Inácio acaba de limpar o nariz e volta para seu lugar para dar continuidade na atividade em curso.

Descrição do episódio: Inácio, ao voltar para seu lugar, olha para a produção da colega Alice. Ele estica seu braço em direção ao palito de madeira que está espetado verticalmente em um pedaço de massa de modelar e, retirando-o da massinha, pega o palito para si. Alice imediatamente grita: 'Não, Inácio!!'. Inácio arregala os olhos, afasta-se e se senta na cadeira, deixando o palito de madeira cair no chão. Alice continua a falar: 'Inácio, não pode pegar o meu palito. Ooh tia, olha o Inácio pegando o meu palitinho'. Inácio olha para Alice, olha para o palito. A monitora se aproxima, abaixa em direção a Inácio e com a voz baixa pergunta a ele por quê ele pegou o palito. Inácio não responde nada e olha para a monitora. Instantes após, Inácio se levanta da cadeira, aproxima-se da colega Alice e mais uma vez estica seu braço para pegar o palito da colega, mantendo seu olhar em Alice. Alice franze a testa e tenta colocar a mão na frente, olhando diretamente para Inácio, na tentativa de impedir sua ação. Porém, ele consegue pegar o palito. Com o palito em mão, Inácio olha para Alice. Alice reclama: 'não, não Inácio'. Inácio joga o palito debaixo da mesa e expressa um discreto sorriso. Agora a monitora senta na cadeira em frente a Inácio, olha para ele e mais uma vez fala que não pode pegar o palito do colega. Inácio mantém o seu olhar na monitora e devagar levanta-se da cadeira e ao levantar-se ele olha para debaixo da mesa, buscando o palito com o olhar. Inácio se afasta, move a cadeira abrindo espaço e vai para debaixo da mesa em busca do palito de Alice. Contudo, a colega Rebeca já havia pegado o palito. A monitora então aponta para Inácio os seus próprios palitos falando que ele já tem material e que não é para ele pegar o material da colega. Inácio olha para Alice, olha para os palitos de Alice sobre a mesa e instantaneamente apanha-os para si. Alice resiste, segurando os palitos com as mãos e a monitora tenta intervir, segurando as mãos de ambas as crianças, enquanto Inácio puxa os palitos em sua direção. Os movimentos de Inácio são rápidos e ele perde o equilíbrio, derrubando os palitos no chão. Alice volta a expressarse falando 'Não, Inácio!!!' enfatizando a entonação no nome do colega. Inácio agacha ao chão para pegar os palitos e, ao voltar, senta à mesa com os demais colegas. A monitora pede os palitos de volta e entrega-os para Alice. Inácio pega seus próprios palitos, olha para Alice e brinca com eles. Após seis segundos, Alice vira em direção à monitora e fala 'eu fiz um bolo'. Inácio olha para Alice e olha para a monitora. A monitora vira em direção a Alice, sorri, levantando a sobrancelha e pergunta: 'bolo de quê?', ao que Alice responde: 'É de laranja'. 'De laranja, que delícia', responde a monitora. Inácio segura os dois palitos com as mãos, vira em direção à monitora, aproxima-se 
dela e murmura algo. A monitora fala: você também fez um bolo!? Inácio balança com a cabeça um sinal positivo e murmura. A monitora fala: 'De Pera. Uhmm, que delícia!'. Inácio volta a se sentar na cadeira, olha para Alice e começa a amassar a massa de modelar com movimentos similares aos da colega. Inácio olha em volta enquanto continua amassando a massa de modelar com os dedos. Inácio está mexendo com pequenos pedaços de massa de modelar. Ele esfrega a massinha com os dedos, olhando para como a massinha se desfaz ao longo do movimento. Alice e Rebeca estão pressionando a massinha contra a mesa em movimentos circulares, modelando uma esfera com o material. Inácio olha para Alice, olha para as mãos de Alice, para a massinha e volta a olhar para suas próprias mãos. Alice continua a fazer os movimentos circulares. Inácio posiciona sua mão direita contra a mesa apoiando seu polegar e seu dedo indicador e com a sua mão esquerda passa um pedaço de massinha (sem forma específica) por debaixo do triângulo formado pelo posicionamento da sua mão. Ao fazer esse gesto, Inácio fala: "goool" e, imediatamente após, levanta suas duas mãos. Alice para o movimento circular que estava fazendo e olha para Inácio. Inácio olha para Alice e repete o gesto. Alice sorri e volta a trabalhar com sua própria massinha. Inácio então sorri, estende as mãos em direção aos colegas e balbucia 'oh, oh', mostrando sua massinha.

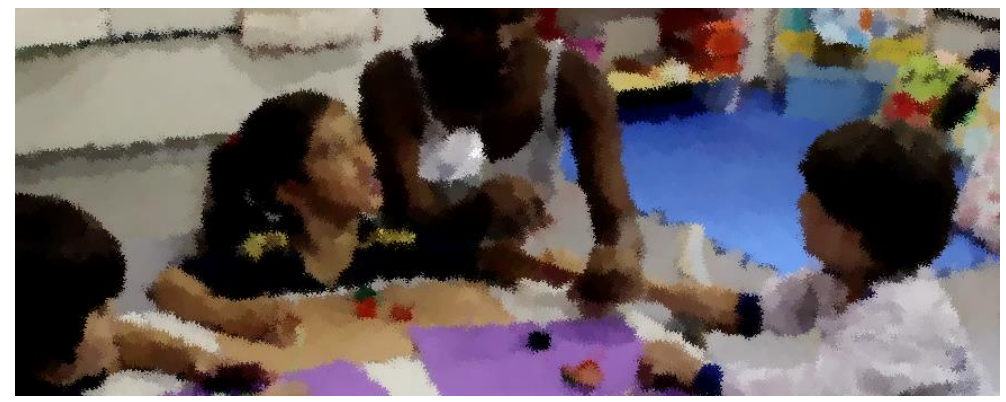

Figura 91. Inácio pega os palitos de Alice pela terceira vez

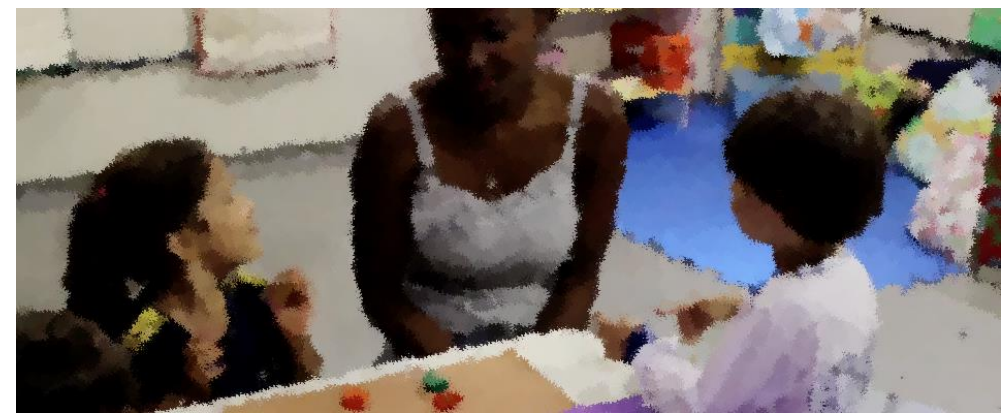

Figura 92. Inácio interage com a monitora e com a colega Alice.

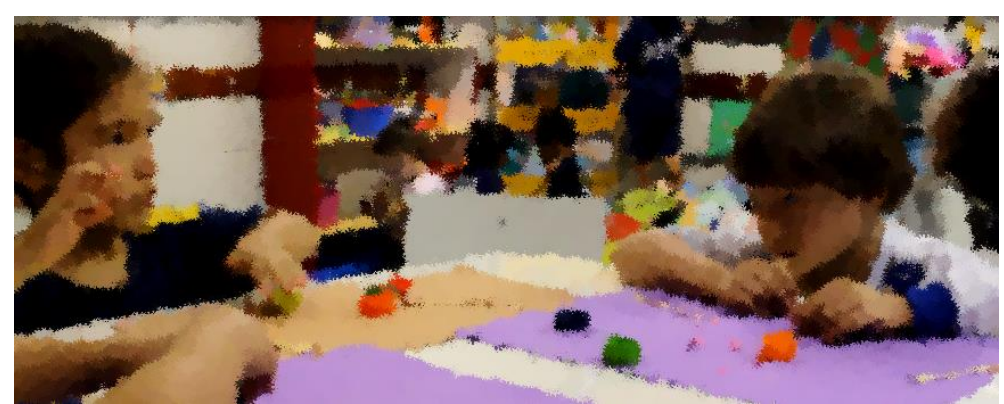

Figura 93. Inácio olha para Isabela enquanto ela enrola a massinha na mesa. 


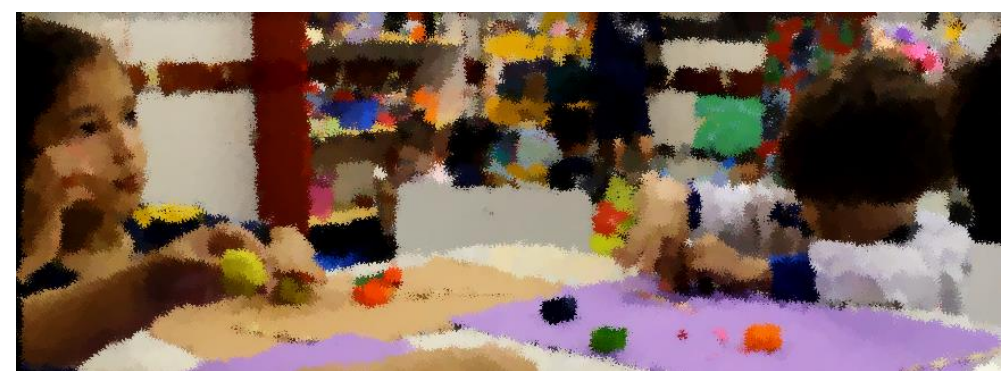

Figura 94. Inácio passa o pedaço de massinha por debaixo dos seus dedos

No início do episódio “É seu, é meu, é nosso”, não é possível inferir sobre o motivo que leva Inácio a querer os palitos de Alice para si. Entretanto, as expressões faciais, os comandos verbais, a sequência de gestos e os comportamentos das crianças, bem como a intervenção da monitora da turma vão construindo um contexto de aprendizagem das regras de convivência para a atividade conjunta. Alice explicitamente delimita o que não é aceitável naquela atividade e os limites do fazer conjunto no compartilhamento dos materiais. Informações são provenientes da organização institucional e vão sendo (possivelmente) incorporadas na cultura de pares.

Neste contexto, é possível identificar que as ações de Alice oferecem indícios para a criança pivô de como aquele contexto está sendo constituído, incluindo nesse, a própria interação em curso. Quando Alice interage com a monitora revelando o sentido do seu fazer com a massinha (bolo de laranja) e a monitora responde ao comentário, sorri para Alice e assim compartilha o significado do faz de conta, cria-se um contexto em que se mostra como é que a interação deve acontecer. Esse é o contexto que Inácio participa e (co)constrói, na medida em que, na sequência, adota os comportamentos da colega Alice como referência e, ainda, estabelece com ela a mesma relação de complementariedade e compartilhamento de significado (a esfera de Alice, que se transforma em bola e que suscita o gol na ação de Inácio) daquela estabelecida com a monitora momentos antes.

Ainda, nota-se por meio da análise microgenética que, com base na descrição da dialética nos estágios de desenvolvimento propostos por Wallon (Oliveira, 2011; Wallon, 2007), identificam-se indícios de que, nessa interação de pares, foram viabilizadas experiências que auxiliam na superação de estágios de desenvolvimento, ou crises próprias de tal processo nessa faixa etária. Tais indícios são encontrados na análise da dialética estabelecida entre a dinâmica inicial de tomar para si o que é do outro (tomada do palitos), a união mimética que funde o indivíduo ao modelo (os comportamentos referentes ao fazer com a massinha) e, posteriormente, a retomada da apropriação do que é do outro como sendo seu (a esfera que vira bola e que dá origem ao gol) de uma forma mais elaborada, abstrata e que complementa a ação do par. Um dos elementos que possivelmente auxiliou esse processo foi a contemplação (Wallon, 2008), identificada nas imitações desde o início da coleta de dados. A contemplação possibilita que Inácio efetive a busca da propriedade das coisas na transformação do 
teu em теи (ver Oliveira, 2011), processo imprescindível para a diferenciação Eu\outro e para o desenvolvimento da representação.

Isto posto, ao se olhar para as corregulações de comportamento do caso Inácio no mês de março, reconhece-se que as ações dos pares propiciaram aprendizagens que auxiliaram a criança pivô nas suas participações nas atividades nesse contexto social, bem como ofereceram suporte e contexto para a superação de crises próprias dos processos de desenvolvimento (aqui fazendo uma referência direta ao modelo de desenvolvimento proposto por Wallon). Dessa forma, corrobora-se com alguns estudos na área da educação (Lee \& Odom 1996; Hanline, 1993) que apontam cenários inclusivos (sistema regular de ensino) como contextos e situações ideais para o desenvolvimento da criança com déficit, destacando as aprendizagens no campo das habilidades sociais.

Ainda, em março já foi possível identificar uma preferência em relação aos pares. Apesar dos dados empíricos serem ainda iniciais, a atenção de Inácio recai sobre as ações de alguns colegas específicos (destaque à Alice, Pedro Augusto e Felipe), crianças que serão de fato pares preferenciais de Inácio ao longo do ano, conforme apontado na fase II de análise dos dados.

No decorrer até agosto, as corregulações de comportamento aparecem em situações mais diversificadas (e.g., em conflitos com pares, na construção conjunta de atividade orientadas e nas atividades livres com os pares). Recorrentemente (seis dos nove episódios específicos de corregulações de comportamento), as corregulações são provenientes das tentativas de Inácio em participar com os pares de atividades já em curso, como explicitado no episódio "Eu também quero brincar”, do dia 05 de agosto de 2014, apresentado na Fase I de análise (ver página 81).

Nessas situações, as corregulações proporcionam a Inácio aprendizagens que também dizem respeito ao processo de socialização, como aquelas apresentadas em março. Todavia, em agosto são identificadas também aprendizagens que estão relacionadas à realização de atividades específicas como, por exemplo, a construção com blocos de montar.

\section{Inácio em: "Você faz e eu desfaço, mas assim eu aprendo"}

\section{Data: 05 de agosto de 2014, gravação n.1 aos 6'10"}

Contexto geral: As crianças estão em momento de atividade livre na sala de aula. Cada criança pode escolher os brinquedos com os quais gostaria de brincar e os pares com os quais dividirá os brinquedos. Inácio perambula pela sala e faz diferentes tentativas de estabelecer parcerias. Nesse momento, algumas vezes, começa a brincar com os colegas, mas perde o interesse; outras vezes os colegas abandonam o fazer conjunto com Inácio e seguem para outras atividades. Após cerca de seis minutos, Inácio senta junto aos blocos de montar e inicia um processo individual. 
Descrição do episódio: Inácio está sentado no tatame brincando com um conjunto de blocos de montar. Lorena está sentada ao seu lado direito, perto da estante de brinquedos de onde olha para Inácio de tempos em tempos. Inácio tenta encaixar dois conjuntos de peças, mas as coloca na direção contrária. Inácio olha para as peças em sua mão, retira um dos blocos da fileira já montada e tenta conectá-lo a outra fileira. Ele deixa as peças caírem e, imediatamente após, coloca as duas mãos na cabeça. Inácio olha ao seu entorno e volta a tentar montar os blocos. Lorena se aproxima de Inácio, senta-se logo a sua frente e começa a montar os blocos rapidamente, fazendo uma torre. Inácio olha atentamente para Lorena, olha para as peças a sua frente e tenta realizar a atividade. Inácio acha a direção correta para o encaixe das peças, mas não consegue firmeza para empurrar as peças juntas. Ele olha para Lorena, que agora já tem uma torre construída. Ele entrega a ela um dos blocos que estava segurando e olha para ela enquanto Lorena coloca-o no alto da torre. Quando Lorena levanta (a torre fica mais alta do que ela alcança sentada no chão) finaliza a instalação da última peça e ela olha para Inácio. Inácio olha para Lorena e sorri. Inácio então puxa com a mão direita alguns blocos na base da torre (aqueles que ele alcança) fazendo-a desmoronar. Lorena, que agora está sentada no chão logo a sua frente, põe-se a montar a torre novamente. Enquanto monta as peças, ela murmura baixo 'assim, agora aqui...' e Inácio observa. Mais uma vez, ao final da montagem, Inácio olha para a colega, olha para a base da torre e puxa-a, desmanchando o trabalho. Lorena, levanta, cruza os braços e fala 'Ah não, Inácio!', vira-se e abandona o tatame. Inácio, olha para as peças de montar que estão espalhadas a sua frente, observa por alguns instantes, olha em seu entorno e, posteriormente, volta ao processo anterior, dessa vez conseguindo encaixar as peças no lugar correto.

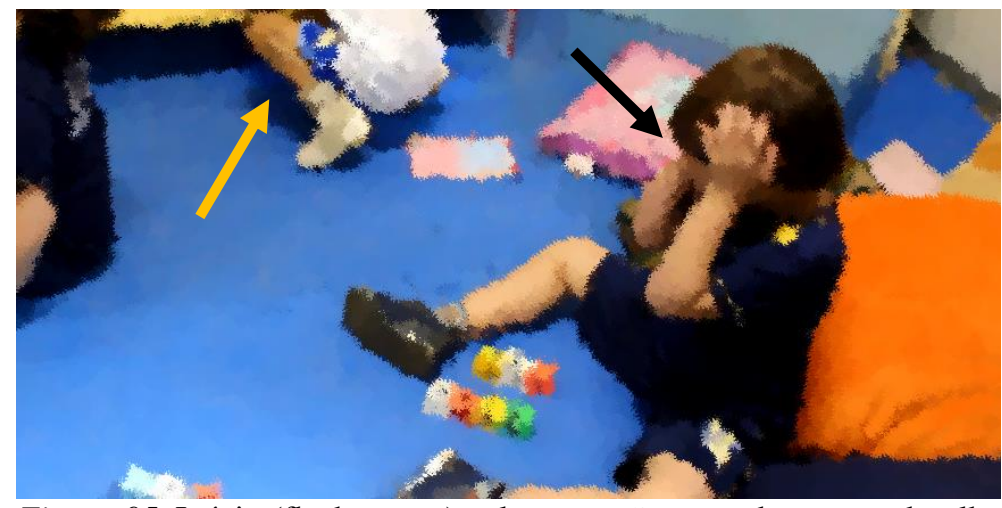

Figura 95. Inácio (flecha preta) coloca as mãos na cabeça quando olha para as peças de montar. Lorena (flecha laranja) pega um brinquedo na estante.

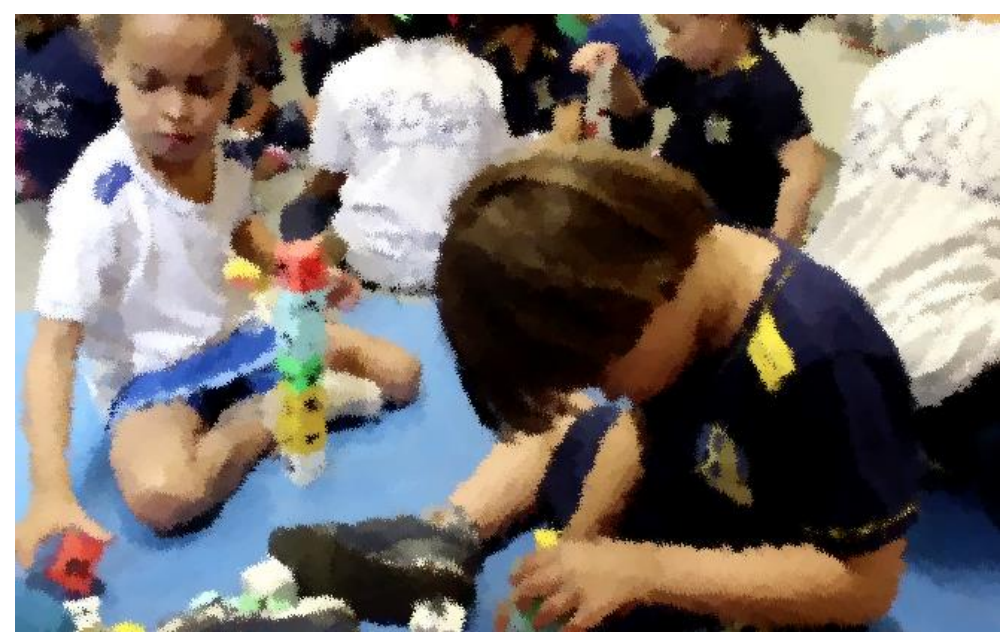

Figura 96. Inácio, tenta montar os blocos. 


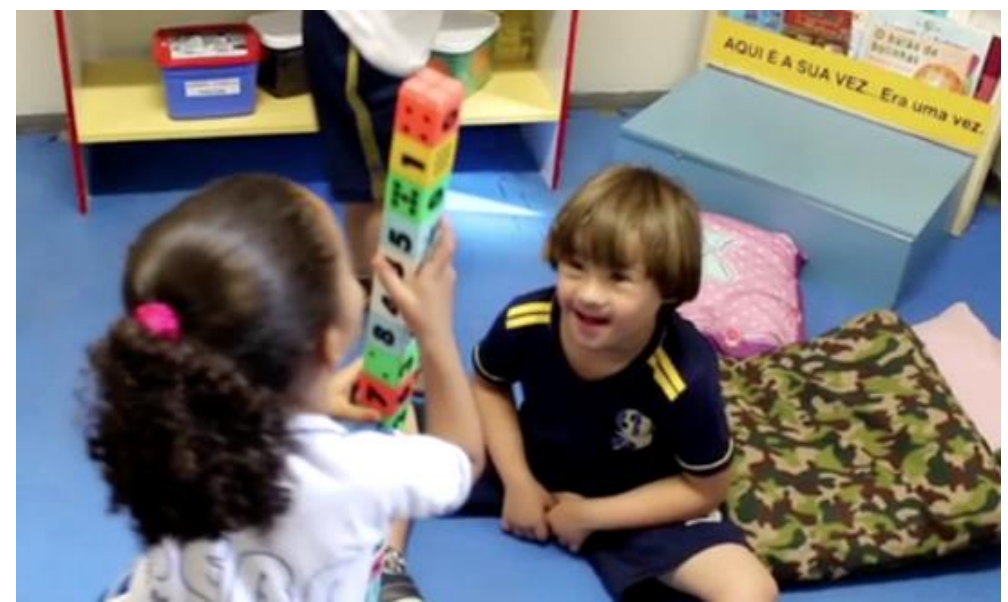

Figura 97. Inácio sorri ao ver a torre construída.

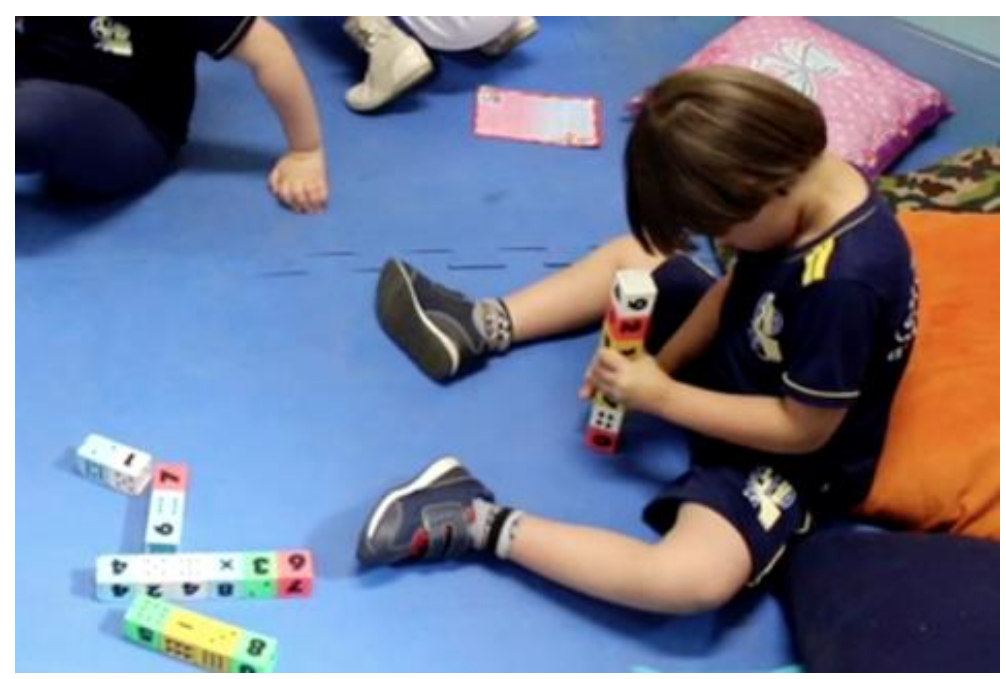

Figura 98. Inácio, na tentativa de montar os blocos após Lorena sair do tatame.

Neste episódio, Inácio encontra-se com dificuldade de montar os blocos de plástico. Sua dificuldade é manifestada e aqui interpretada pela expressão facial ao olhar para os blocos enquanto levanta suas mãos e posiciona-as na cabeça - um gesto cultural que comumente é interpretado como frustração, desalento, confusão e outros relacionados. Imediatamente após esse gesto, Lorena, que se encontra a todo tempo nos arredores de Inácio o observando, se aproxima. A aproximação de Lorena impõe instantaneamente um modelo de como montar os blocos, ou seja, um modelo da atividade que Inácio encontrou dificuldade em realizar. Não é possível saber se Lorena acompanhou todos os movimentos de Inácio e se isso a motiva a interagir com ele. Mas, entende-se por esse processo, que as corregulações de comportamento viabilizaram a aprendizagem para a realização dessa atividade específica - montar blocos. A ação do par, mesmo que ausente de instruções verbais diretamente relacionadas com a atividade em curso, possivelmente proporcionou à Inácio as pistas necessárias para que ele a efetivasse. 
Aqui, mais uma vez se identifica a contemplação e a imitação com modelo (Wallon, 2008) como mecanismos que estruturam os movimentos tônicos de Inácio no processo interativo e que, por sua vez, oferecem a base para a reprodução das ações que a atividade demanda. Cabe neste momento enfatizar que não se trata de pressupor que a realização da montagem dos blocos por Inácio, após o modelo oferecido por Lorena seja, necessariamente, uma aprendizagem inédita. Talvez não seja. Mas, mesmo não sendo, defende-se a ideia de que, para aquele momento específico, no contexto da rotina escolar, a montagem de blocos tenha se configurado enquanto a atividade em que Inácio não conseguia realizar sozinho (seja por qual for o motivo) e que, com a ajuda do par, mesmo que simplesmente relembrando-o de algum fragmento do processo (e.g., a rotação da peça) viabilizou que ele executasse a atividade, contribuindo para o desenvolvimento das suas habilidades.

Esse tipo de corregulações de comportamento oferece alguns indícios empíricos que possibilitam a reflexão sobre a perspectiva diádica da Zona de Desenvolvimento Proximal (Holzman, 2010), em que existe um entendimento de que a ZPD perpasse a díade assistencial de um companheiro mais capacitado para a realização de uma atividade, que sozinha a criança não é capaz de executar. Tal perspectiva é encontrada nas interpretações de Wood, Bruner e Ross (1976) quando da criação do termo scaffolding e, posteriormente, discutida por outros estudiosos da teoria de Vygotsky, tais como Shotter (1989) e Wertsch (1991). Na área da educação especial, alguns estudos recentes adotam a interpretação da ZDP relacionada a um processo de scaffolding e defendem-na enquanto uma das significativas formas de promover aprendizagem em contextos inclusivos (Ferguson, 2008; Mäkinen \& Mäkinen, 2011; Pfister, Moser \& Pauli, 2015), enfatizando o seu aspecto colaborativo na construção de conhecimento (Guzdial, Carlson \& Turns, 1995).

Além de apresentar um diferente objeto de aprendizagem (realização de ações específicas), no mês de agosto é reconhecido também um envolvimento maior dos pares nas atividades conjuntas com Inácio; inferência que advém do quantitativo dos episódios de corregulações de comportamento e também do movimento do par em direção a Inácio. Ou seja, pares movimentam-se em direção a Inácio (quatro dos nove episódios) ao invés de simplesmente estarem presentes lado a lado na atividade (como nos episódios do mês de março). Contudo, a estrutura básica da corregulação é ainda pelo provimento de um modelo e das sucessivas possibilidades da imitação desse modelo.

Em dezembro, na última semana de aula, todos os quatro episódios de corregulações de comportamento ocorreram exclusivamente em situações de atividades conjuntas livres no contexto do playground, sendo marcadas particularmente por processos de comunicação entre diferentes crianças. As ações dos pares propiciam aprendizagens relacionadas ao desenvolvimento da verbalização enquanto veículo de comunicação, demarcando uma estrutura de interação diferente. 


\section{Inácio em: "Deixa eu te explicar"}

\section{Data. 03 de dezembro de 2014, gravação n. 3 aos 9'29',}

Contexto geral: No episódio em questão, Inácio e Breno engajam-se em um processo comunicativo, em que Inácio explica um evento ocorrido (minutos antes, o aluno Ivan em interação com Inácio, arremessa seu tênis em direção ao topo do escorregador). Mesmo sem o domínio dos códigos linguísticos convencionais para se expressar, Inácio e seus pares constroem a comunicação.

Descrição do episódio: Inácio está sentado debaixo do escorregador, de onde observa um grupo de crianças brincando. Breno aproxima-se de Inácio se senta debaixo do escorregador e pergunta: 'Inácio, o que aconteceu com o seu tênis?' Inácio vira-se em direção ao colega, olha por alguns instantes para ele e balbucia algo (não compreensível) e gesticula com a mão esquerda em um movimento circular grande e fala 'em pu'. Breno responde perguntando 'como que você vai pegar?', o que faz com que Inácio faça outro movimento circular grande, agora com a mão direita e logo em seguida, com as duas mãos. Inácio permanece gesticulando e apontando com as mãos para o espaço ao seu redor. Ao mesmo tempo em que gesticula Inácio balbucia sílabas 'no' 'em pu' 'rô' 'dor'. Breno olha para Inácio e quando ele finda os movimentos com as mãos, Breno fala: 'O Ivan deve ter descoberto todas'. Inácio continua agora fazendo um gesto específico com a mão direita, posicionando o polegar e o dedo indicador perto um do outro e apontando para o topo do escorregador. Ao mesmo tempo em que gesticula, Inácio balbucia sílabas e sons 'rá', 'ta', 'dor'. Em seguida, Breno pergunta: mas cadê o outro tênis?', a que Inácio sonoriza um 'rô' ao mesmo tempo tem que aponta para o topo do escorregador. 'Voou?' pergunta Breno. Inácio, vira-se em direção ao fundo do escorregador, aponta para os lados e para o topo do brinquedo. Ele olha para Breno, balbucia diferentes sílabas e por fim toca o queixo de Breno. Breno olha para uma criança (não identificada) a seu lado, virando sua cabeça e narra para o colega 'O Ivan pegou o tênis dele e jogou no escorregador'. Depois, completa dizendo, 'tem que achar o seu tênis'.

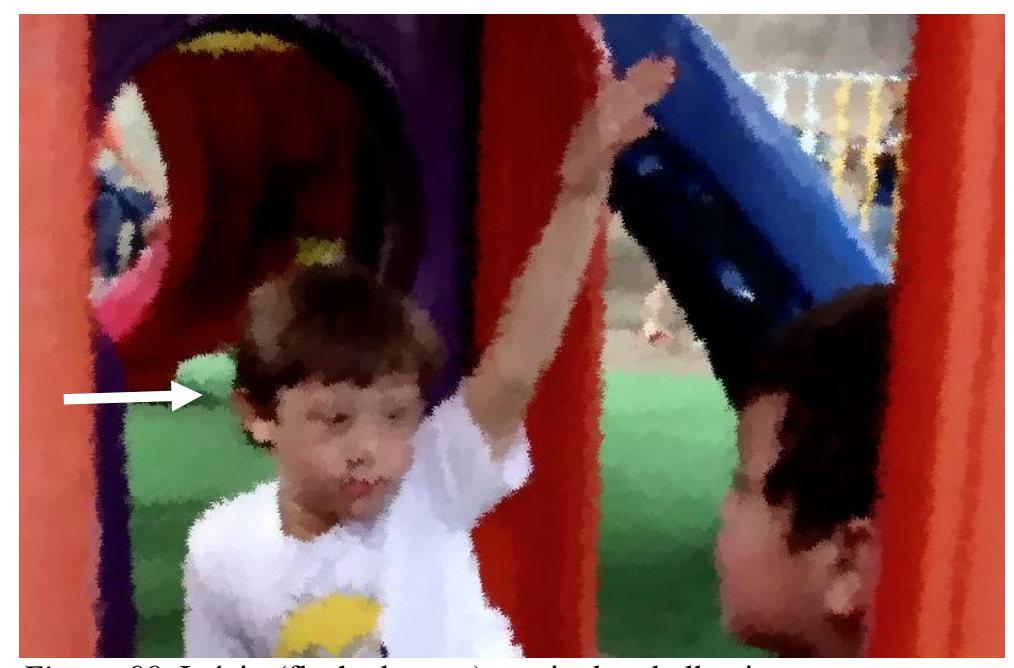

Figura 99. Inácio (flecha branca) gesticula e balbucia o que aconteceu para Breno.

Neste episódio, a corregulação de comportamento acontece por meio tanto de gestos e expressões faciais, quanto pela fala, expressada pelos signos convencionais (Breno) e por uma dinâmica gesto-verbal (Inácio) que se assemelha aos processos identificados na protoconversa de 
bebês e adultos (Tomasello, 2003; Delafield-Butt \& Trevarthen, 2013; Trevarthen \& Aitken, 2001), em uma dinâmica que viabiliza a construção de significados entre as crianças. Cabe destacar dois aspectos considerados relevantes: o primeiro, diz respeito a utilização dos gestos na comunicação e o papel deles para a interação de pares neste contexto; e, o segundo, a ação do par no processo de construção de significado e a possibilidade de desenvolvimento a partir disso.

Segundo Novack e Goldin-Meadow (2015), os gestos adicionam um componente espacial e imaginativo à comunicação verbal e como os gestos não estão confinados pelo sistema linear de regras da linguagem falada, eles têm o potencial de expressar ideias que podem ser difíceis de serem comunicadas por palavras. No mesmo estudo sobre as possibilidades de aprendizagem através de gestos, Novack e Goldin-Meadow apresentam uma revisão sobre como esses contribuem ou circunscrevem processos de aprendizagem e, especificamente, apontam a sua relevância para construção de conceitos e para o desenvolvimento da linguagem nos anos iniciais da infância. Neste episódio específico, os gestos guiam a narrativa de Inácio sendo manifestados a priori à verbalização, em um processo que sinaliza para o par o conteúdo em questão. Nos gestos de Inácio se encontram os elementos constituintes da narrativa (local onde a história acontece, direção das ações, conteúdo emocional) que vai sendo complementado pela verbalização de algumas sílabas, possivelmente que fazem relação com os signos verbais (palavras) representativos dos objetos ou ações narradas. Os gestos compõem a protoconversação e desempenham um papel importante na manutenção da atenção conjunta com o par. Tal análise vai ao encontro do que aponta Furlan (2004), que "todo o comportamento é portador de um sentido" (p. 54).

Ainda segundo o autor supracitado,

“A apreensão dos sentidos é inicialmente, pré-linguística, da ordem da intencionalidade de um corpo cuja expressão não se faz ainda pela fala e que, mesmo com o advento dessa, permanecerá uma forma própria e irredutível de apropriação de sentido de mundo" (Furlan, 2004, p.51).

A ação do par neste sentido é o que vai permitir, no ritmo do processo comunicativo, as interpretações dos gestos e das verbalizações em uma narrativa que vai ser, posteriormente, compartilhada com as demais crianças. Para Trevarthen (1993), a linguagem é inventada na experiência comum, uma ferramenta fabricada da fantasia humana coletiva, aprendida pelo compartilhamento. Assim, é por meio dessas interpretações e, consequentemente, do compartilhamento de significado na interação, que a Inácio é permitida a expressão da sua história, a elaboração da sua narrativa e a existência naquele grupo enquanto alguém que é ouvido. A 
aprendizagem proporcionada por essa interação está diretamente relacionada à construção das rotinas culturais de pares e, na medida em que Breno vai reformulando em palavras os gestos e vocalizações de Inácio, é possibilitado à criança pivô experimentar a adequação e ampliação de signos no processo comunicativo. É neste momento que se entende que a linguagem não seria apenas instrumento, tampouco modo ou ação, mas seria o próprio processo de constituição social do homem (Smolka, 1995).

No mês de dezembro, diferente dos meses anteriores, os episódios de corregulações de comportamento não mostram transformações de habilidades específicas em curso, mas evidenciam uma significativa transformação na estrutura da interação de uma forma geral, incluindo agora o diálogo verbal (mesmo que ainda em protoconversa) no processo comunicativo. Considerando os argumentos previamente expostos, a relevância e o processo como se dá o desenvolvimento da linguagem, discute-se a criação de Zonas de Desenvolvimento Proximais pela interação de pares a partir do reconhecimento de como ação dessas crianças é constituidora de modos de abreviação que permitem o compartilhamento de significado no processo comunicativo (Carvalho et. al., 1996). Segundo Oliveira, Guanaes e Costa (2004), o processo de interiorização proposto por Vygotsky se configura enquanto:

"Formas de selecionar focos de atenção, de memorizar, de realizar experimentos, que de início ocorrem em uma esfera interpessoal, são transferidos para um âmbito intrapessoal, em um processo denominado 'interiorização'. Isso se faria através da palavra que, de início, é a do outro, a do parceiro mais experiente” (p. 70),

A partir dessa referência e sua relação com as Zonas de Desenvolvimento, se entende que experiências como essa apresentada na tarefa partilhada da construção da narrativa do que aconteceu com Inácio, encontra-se a zona limite entre o que seja a ação da criança pivô e a ação do par e é justamente nesse processo que, segundo Vygotsky (conforme Oliveira, Guanaes \& Costa, 2004), "os indivíduos se apropriam do que é exterior e usam-no para orientar suas próprias ações” (p. 70). Ainda, a própria diferença estrutural da interação entre os meses de março (que inclui apenas gestos e vocalizações) e em dezembro (que se estabelece com ritmo do diálogo convencional e com estruturas verbais) indicam processos de desenvolvimento.

Em suma, ao se refletir sobre como as corregulações de comportamento se constituíram de março a dezembro no estudo de caso de Inácio, destaca-se: (1) um gradativo aumento de interesse dos pares nas ações de Inácio, inferido por meio do aumento no número dos episódios de interação em que são os pares que procuram pela criança pivô; (2) identificam-se diferentes aprendizagens, que 
inicialmente, estão relacionadas à construção de rotinas culturais de pares e em processos sociais em que a diferenciação Eu\outro vai sendo estruturada e, posteriormente desenvolvem-se perpassando o desenvolvimento de habilidades específicas na ação com o par e proporcionando contexto e estrutura para possível desenvolvimento da linguagem; e, (3) entende-se que em todos as três fases de coleta de dados (início, meio e final) foram encontrados elementos que permitiram a discussão da criação de Zonas de Desenvolvimento Proximal pelas interações de pares.

\section{Estudo de caso Ivan}

Nas análises realizadas no período inicial da coleta de dados, não foram encontradas evidências da busca por pares específicos, embora seja Ivan quem tenha estabelecido a maior parte dos contatos físicos (quatorze iniciados por Ivan e cinco iniciados pelos demais pares). As corregulações de comportamento aconteceram no contexto da sala de aula, estruturaram-se em torno da participação de Ivan nas atividades em andamento (dois momentos de atividades orientadas pela professora e um de atividade livre) e, dentro desse recorte temporal, foram os pares que mais regularam os comportamentos de Ivan (duas vezes). Tais regulações foram marcadas pela imitação simultânea, ainda que em um diálogo tônico elaborado com diferentes recursos gestuais (episódio 'Fazendo parte da rotina na escola') e por comportamentos com propósitos específicos e autorregulados, mesmo que nesses ainda seja evidenciada uma dificuldade das crianças em compartilhar significado (episódio 'Vamos brincar de dormir?').

\section{Ivan em: "Fazendo parte da rotina na escola"}

\section{Data: 27 de março de 2014, gravação n.1 aos 6' 17',}

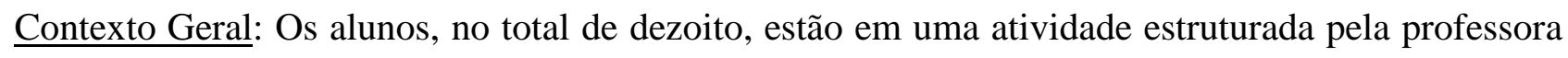
em que foi orientado a eles que desenhassem parte da história que foi contada por ela. Os alunos recebem uma folha em branco para estruturarem o seu desenho e dividem o espaço da mesa com outras três crianças. Nessa cena em específico, Ivan dividirá a mesa com Gabriela, Ana Cláudia e Laila.

Descrição da cena: Ivan e três colegas (Gabriela, Ana Cláudia e Laila) estão sentados à mesa, aguardando a entrega do material para a execução da atividade prevista. Quando a professora deposita o estojo de lápis de cor no centro da mesa, Laila retira imediatamente um lápis cor-de-rosa. Ivan, que está olhando para a colega, aproxima-se da mesa, estica sua mão para alcançar a caixa com os lápis de cor e retira para si um lápis. No decorrer, as outras duas crianças também retiram para si um lápis de cor. As crianças brincam com o componente lápis de cor. Ivan olha atentamente para o movimento das colegas. Ivan levanta-se, mexe com a cadeira, movimenta-se, até que uma das monitoras solicita que ele volte a sentar-se junto com as três colegas. A professora entrega uma folha de papel em branco. Ana Cláudia recebe a folha em branco e imediatamente começa a escrever no 
canto superior esquerdo da folha o seu nome e, posteriormente, começa a desenhar no centro da folha. Ivan olha para Ana Claudia. Ivan recebe a folha em branco e imediatamente começa a desenhar na sua folha. Ele olha para as colegas (Laila e Gabriela). Ele troca de lápis de cor, olha para as mãos de Gabriela e desenha em sua folha. Troca mais uma vez o lápis de cor, dessa vez, trazendo o componente de lápis de cor para mais perto de si e escolhendo do montante a sua opção. A monitora, nesse momento carrega uma cadeira para o outro lado da mesa e posiciona-se ao lado de Ivan. Gabriela, Ana Cláudia e Laila reclamam que gostariam que ela sentasse perto delas. Ivan olha para as colegas enquanto segura o estojo com os lápis de cor. A monitora conversa com as meninas da mesa. Ivan devolve a caixa de lápis de cor, retirando apenas um para si. Ele olha rapidamente para Ana Claudia e volta a desenhar. As colegas desenham em seus papéis. Ivan olha para as colegas, para seu papel e novamente para as colegas (alternando o olhar para as diferentes colegas). Laila olha para Ivan. Ele volta à atividade e continua a desenhar em sua folha.

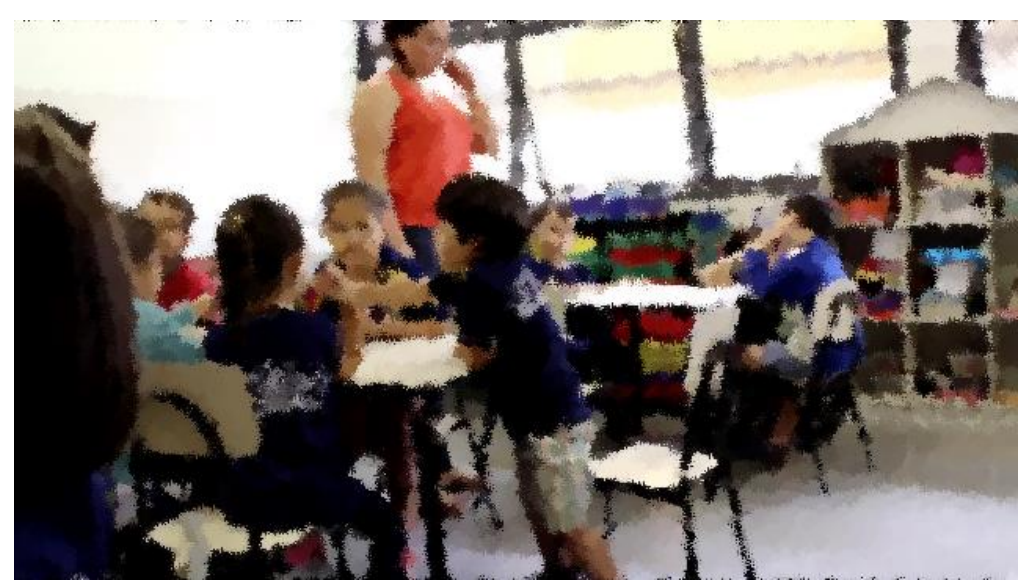

Figura 100: Ivan estica o braço para alcançar a caixa de lápis de cor.

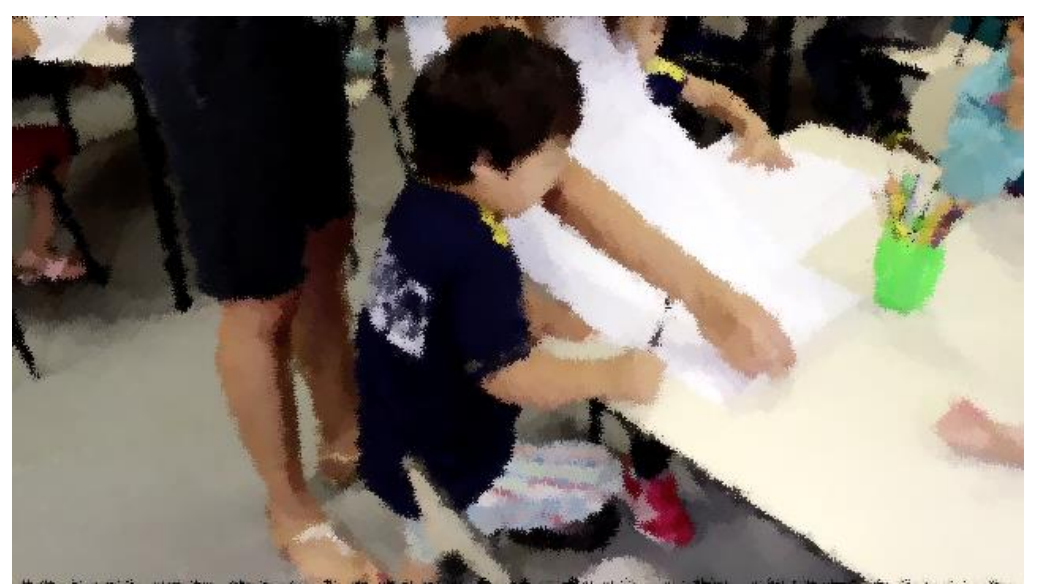

Figura 101: Ivan recebe sua folha de papel. 


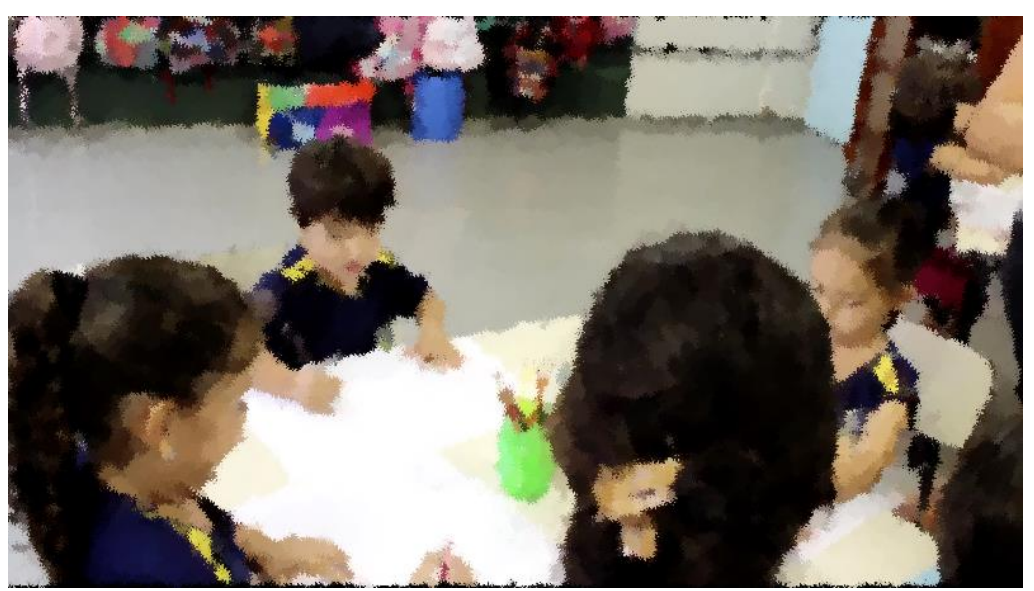

Figura 102: Ivan olha para o desenho e mãos da colega Gabriela

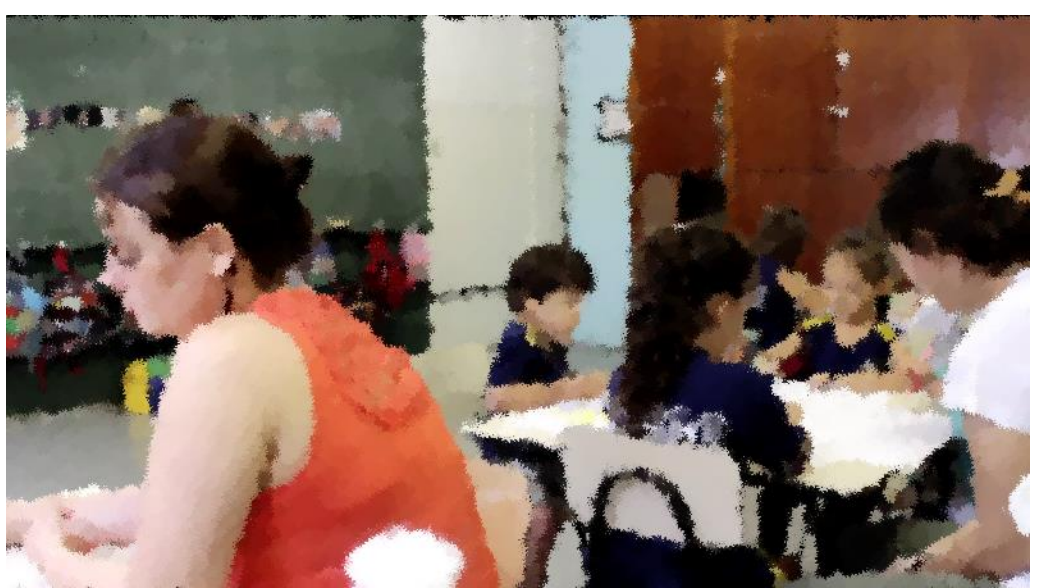

Figura 103: Ivan olha para o desenho e mãos da colega Laila

Neste episódio, o primeiro movimento de regulação de comportamento é marcado quando Ivan estica o braço para alcançar o lápis de cor, imediatamente após sua colega (Laila) assim o fazer. Ivan, que havia sido posicionado pela professora naquele grupo, engaja-se na dinâmica contida na atividade seguindo e imitando sequencialmente os comportamentos das colegas, alternando a sua fonte de referência. A imitação neste episódio (olhar para as mãos e para o desenho das colegas, fazer o seu próprio desenho), são cópias simultâneas dos comportamentos das demais crianças, que ocorrem intercaladas pelas ações de desenho da própria criança, em meio a uma atmosfera emocional criada pela composição em grupos e cuja dinâmica é definida por uma atividade de desenho.

Cabe destacar que a imitação, enquanto comportamento de copiar gestos, ações ou movimentos de Outro, poderia ser aqui analisada e discutida por meio da perspectiva de base neuro-cognitiva proposta por Paulus (2011), em que a imitação é caracterizada pela similaridade e conectividade causal de dois comportamentos, independentemente do tipo de mecanismo neuro-cognitivo utilizado pela criança no processo imitativo (mímica, emulação ou leitura das intenções) (Gallese \& Goldman, 1998; Paulus, Hunnius, Vissers \& Bekkering, 2011). A partir desse princípio e considerando as suas características, esse episódio seria entendido, por exemplo, enquanto um processo de emulação, 
possivelmente executado a partir do reconhecimento de ações superordenadas (Woodward \& Sommerville, 2000). Por essa linha de raciocínio, não há inferências prévias sobre a capacidade da criança de entender as intenções que motivam as ações dos pares, pois os processos que explicam a imitação não necessariamente vinculam-se a essa habilidade; a imitação seria explicada a partir da necessidade da atividade em curso; a criança imita o par porque é ele quem executa a ação. Uithol e Paulus (2013) alegam que entender uma ação consiste em uma sequência heterogênea de processos de predição e antecipação de ações; que essa competência expande ao longo do tempo utilizando-se de diferentes mecanismos (classificação das ações, predição de tarefas alvo, reconhecimento de ações superordenadas, reconhecimento de seleção de respostas), e que não existe um ponto óptimo para que esse processo ocorra, ou seja, "não é uma capacidade que uma criança tem ou não tem com determinada idade" (p.10). Uithol e Paulus defendem que a intenção precisa ser atribuída ao invés de inferida e que esse processo não se trata de um mecanismo único, ao contrário, trata-se de um conjunto de mecanismos. Ainda, essa atribuição de intenção de uma ação poderia ou não ser um mecanismo que explicaria a imitação, mas estaria diretamente relacionado com o desenvolvimento das competências linguísticas na infância.

Todavia, quando considerados os aspectos circunscritores do episódio (as demais crianças, as diferentes ações que ocorrem em paralelo, a presença de adultos, os demais estímulos visuais e sonoros e etc.), ou seja, quando o processo imitativo é analisado dentro da complexidade do campo de interação, o contexto contribui para o entendimento de que mesmo que Ivan esteja utilizando mecanismos neuro-cognitivo como os acima descritos, existe uma leitura da dinâmica do contexto em seu entorno que orienta as suas escolhas. Ivan imita gestos específicos (aqueles que estão relacionados à sua participação na dinâmica da atividade em curso), a partir do conjunto de ações daquele grupo de crianças, tornando a atividade de desenho e curso parte de seu repertório. Assim, corrobora-se com Tomasello et. al (2005) que defendem a necessidade de se analisar os comportamentos de aprendizagem social e imitação considerando as capacidades sócio cognitivas das crianças em seu percurso de desenvolvimento e o contexto em que esses comportamentos são executados.

Entende-se, portanto, que da mesma forma que a criança necessita do outro para a sobrevivência física (provimento de alimento e cuidados básicos), também assim necessita para sua sobrevivência cultural. Neste contexto social, Ivan necessita do outro para agir de acordo com os padrões do grupo ao qual pertencelpertencerá, uma vez que ainda não domina os signos contidos na orientação verbal dada pela professora. É, neste caso, o fazer do outro, que vai (co)construir com ele os moldes culturais, permitindo que haja a participação da criança no processo em andamento. 
Para obter as informações necessárias sobre o meio ao seu entorno, o principal recurso de que essa criança dispõe inicialmente é o olhar, a percepção corpórea e a imitação desse outro, mesmo que ainda sem construir sentido do fazer em curso (a atividade estruturada proposta pela professora). Desse modo, dá-se a fusão com os que lhe são próximos e, embora se tratando ainda de automatismos, estes, segundo Wallon (2008), já lembram o caráter contagioso das emoções. Ainda, segundo Meltzoff e Moore (1994), os comportamentos imitativos das crianças também se referem a reafirmação de laços de amizade ou afiliações, qualificando uma relação de afeto ou o pertencimento a um grupo. E, neste sentido, no processo deste episódio, destaca-se que o olhar de Ivan permanece a todo tempo na atividade realizada pelos pares (olhar direcionado diretamente ao par ou à folha de papel), mesmo tendo à sua disposição (logo ao seu lado), a monitora (o adulto). Ao longo de todo o episódio, Ivan não solicita o auxílio ou busca com o olhar, a intervenção do adulto. A referência é apenas o par. Esses dados abrem espaço para se inferir que, mesmo sem consciência dos processos em seu entorno, Ivan reconhecelpercebe que é através dos pares que essa participação ocorra. Entende-se que exista uma identificação imediata com as demais crianças do grupo e uma busca por referências que venham dessas crianças, conforme encontrado em estudos sobre a construção de cultura na infância (Corsaro, 2003; 2005; Lucena, 2008).

As crianças (Laila, Ana Claudia e Gabriela) não têm, necessariamente, consciência do processo regulatório em curso, tampouco expressam qualquer comportamento que permitiria a inferência sobre uma possível intenção em proporcionar auxilio a Ivan. Contudo, o episódio revela que mesmo sem essa intencionalidade, as ações dos pares ofereceram à criança pivô, elementos para coordenar suas ações frente à demanda apresentada (participar do momento de desenho). Esta é uma dinâmica que corrobora com estudos que apontam aos possíveis benefícios de um ambiente institucional regular de ensino para a criança com deficiência (Cobb-Moore, 2008; Cole, Waldron \& Majd, 2004; Linday, 2007). Neste sentido, entende-se que Zonas de Desenvolvimento Proximais estão sendo criadas quando se analisa a atividade pela sua finalidade curricular (registrar as produções gráficas das crianças após a contação da história) e não necessariamente pela perspectiva do tipo de traço e habilidade para o desenho em si. Os pares desempenham, para isso, um papel de suporte para que Ivan se oriente na dinâmica da atividade, construindo conjuntamente o momento coletivo (Corsaro, 2005).

\section{Ivan em: "Vamos brincar de dormir?"}

\section{Data: 27 março de 2014, gravação n.2 aos 9'30",}

Contexto: As crianças estão num momento de atividade livre, em que podem escolher o que querem fazer e quais materiais querem usar. Ivan está no 'cantinho da leitura' folheando um livro, quando 
algumas crianças se aproximam para brincarem em meio às almofadas, no tatame. A monitora da sala encontra-se do outro lado da sala conversando com a professora.

Descrição da cena: Ivan, que está sentado ao lado da estante de livros folheia um exemplar até o momento em que avista Pedro e mais dois outros meninos se aproximarem. Ivan olha para Pedro, fecha o livro e o coloca de volta na estante. Ivan olha novamente para Pedro, que por sua vez está sentado em meio às almofadas, olhando para os demais colegas brincarem. Pedro deita nas almofadas. Ivan se aproxima de Pedro. Pedro continua deitado nas almofadas. Ivan deita na almofada ao lado de Pedro, sorri, fecha os olhos e passa a mão no rosto de Pedro. Pedro levanta, mantendo-se sentado e olhando com os olhos arregalados para Ivan. Ivan se senta, bate duas vezes com a mão direita na almofada e olha para Pedro. Pedro franze a testa, olha ao redor em outra direção e se afasta. Ivan olha para o colega, aproxima-se novamente, coloca sua mão esquerda no peito do colega e empurra-o em direção à almofada. Pedro resiste e se afasta ainda mais. Ivan olha para Pedro e repete o gesto. Pedro arregala os olhos, vira-se em direção oposta a de Ivan e tenta se levantar. Ivan move-se em direção ao colega, com os braços abertos e se direcionando para cima do mesmo. Pedro cai para trás e na queda a boca de Ivan bate nas bochechas de Pedro e ele começa a chorar. Ivan olha para o colega e permanece abraçado nele. A professora escuta o choro $e$ imediatamente vem ao encontro das crianças. Ivan abaixa os braços, olha para a professora, olha para o colega e permanece sentado. A professora pergunta o que aconteceu. A monitora responde: "ele mordeu o Pedro". As crianças olham para Ivan, e ele permanece sentado no tatame.

$\mathrm{Na}$ análise da interação particular desse episódio, as corregulações de comportamento construíram um momento de busca de contatolfazer junto dolcom o outro, que teve seu início demarcado pela aproximação física de Ivan a Pedro e pela imitação de um comportamento específico (Ivan imita Pedro ao deitar-se nas almofadas). Até esse momento, Ivan apresenta apenas comportamentos imitativos que são uma cópia simultânea das ações do par, que poderiam ser caracterizados como mimetismo (Wallon, 2008). Contudo, o comportamento de Ivan é recebido pelo par (Pedro) com estranheza (olhos arregrados, afastamento físico imediato) e dá início a uma negociação entre as crianças, em que os sentidos subjetivos não são transformados em significados compartilhados, chamando a atenção para a análise do processo comunicativo das crianças.

O afastamento físico de Pedro corregula os comportamentos de Ivan, provocando uma mudança na sua postura tônica, desta vez o que se vê é o uso de um gesto indicativo representativo de uma intenção (Ivan aponta para a almofada, batendo-lhe com a mão, ao mesmo tempo em que olha para o colega). Os gestos indicativos (e.g. apontar o dedo) são gestos sofisticados que aparecem no bebê humano por volta dos onze meses de vida, abrindo as portas para o desenvolvimento dos processos comunicativos (Camaioni, Perucchini, Bellagamba \& Colennesi, 2004). Segundo Tomasello, Carpenter e Liszkowski (2007), tais gestos podem carregar duas diferentes intenções comunicativas: imperativas e declarativas. Neste episódio, Ivan utiliza-se de gestos imperativos - em que a intenção é obter do Outro uma ação específica ou um objeto desejado - e comunica a Pedro a 
sua intenção de que ele deite nas almofadas. Destaca-se aqui, que a utilização desse gesto evidencia a habilidade da criança de fazer referências a eventos e objetos exteriores, na tentativa de influenciar os comportamentos do Outro em questão (Liazkowski, Schärfer, Carpenter \& Tomasello, 2009), elemento considerado primordial pelos autores para o desenvolvimento da diferenciação eu-outro e dos processos representativos.

Na continuação da cena, verifica-se, contudo, que o gesto imperativo de Ivan não provoca resultados condizentes com sua intenção, uma vez que o par apresenta comportamentos e expressões faciais (franze a testa, olha para outra direção, não responde verbalmente nem gestualmente) que não condizem com a ação desejada por Ivan (deitar nas almofadas). Ivan permanece na tentativa de fazer com que o colega volte a se comportar como antes mas, na sequência, utiliza-se do próprio corpo como meio de comunicação (se posiciona perto do colega e empurra-o com o braço). A mudança do gesto para a ação corpórea demanda maior envolvimento físico, controle tônico e altera o processo representativo característico dele, materializando o movimento contido na intenção de Ivan para a construção do fazer conjunto com Pedro. Mesmo com a mudança na estratégia comunicativa, as respostas corporais de Pedro permanecem iguais, indicando a manutenção de uma comunicação em que asintenções do outro não são entendidas elou compartilhadas. Para além, na quarta tentativa de fazer com que o par volte para a posição inicial (deitado na almofada), Ivan muda a estratégia de contato, agora abraçando o colega e seguindo com seu corpo em direção a Pedro. O movimento em curso resulta na queda e no posicionamento da boca de Ivan sobre as bochechas de Pedro. A estranheza identificada nas expressões faciais de Pedro dá lugar ao choro (curto, estridente e sem lágrimas aparentes). Essa expressão de emoção e a posição física de Ivan sobre o colega é interpretada pelos adultos envolvidos no contexto (professora e monitora) como agressividade, expressa por uma mordida.

A complexidade contida nesse episódio abre espaço para a discussão de diferentes aspectos da interação dos pares, destacam-se, contudo, três: a corregulação que não advém do compartilhamento de significados; a potencial aprendizagem contida no conflito; e, a atribuição de significado às ações na interação de pares que definem a forma pela qual a criança participa no contexto social.

$\mathrm{Na}$ definição de regulação e corregulações que inspira esse trabalho (Carvalho et al 1998; Carvalho, Império-Hamburger \& Pedrosa, 1996; Carvalho \& Rubiano, 2004; Pedrosa, 1989), a corregulação de comportamento é identificada a partir "do ajustamento mútuo pelo qual os parceiros alcançam um acordo a respeito de um significado, ou seja, cria-se um significado compartilhado" (Carvalho \& Rubiano, 2004, 173). Contudo, neste episódio é justamente a ausência do compartilhamento de significado que caracteriza o tipo de interação e justifica, na dinâmica, as ações 
dos pares. Dessa forma, entendeu-se essas ações enquanto corregulações de comportamento considerando a permanência física das duas crianças nesse espaço compartilhado e a direção da atenção das crianças (um para o outro), e utilizou-se dos princípios de contextualidade, viabilidade e constituição (De Jaegher, Di Paolo \& Gallagher, 2010) para identificar a causalidade entre as ações.

A interação que circunscreve todo esse episódio indica que Ivan não reconhece os sinais expressos pelo par (expressões faciais, afastamento físico, rigidez corporal) como indicativo de não engajamento o que, consequentemente, leva-o a permanecer com o gesto de empurrar o colega na tentativa de colocá-lo deitado na almofada. Ao mesmo tempo, Pedro (o par) também não compreende a intencionalidade nas ações de Ivan ou não consegue oferecer a Ivan indicativos mais evidentes que explicitariam o seu não querer realizar a ação proposta. Assim, a forma como a interação vai sendo constituída não oferece indícios suficientes para que as crianças, com suas competências sócio cognitivas, construam uma atividade conjunta em que os significados sejam compartilhados. Contudo, ao negar comportar-se da maneira como Ivan solicita (seja por não entender ou por não compartilhar dos interesses de Ivan), Pedro oferece a oportunidade de Ivan apresentar diferentes recursos comunicativos para expressar sua intenção, ressaltando que o não contato, a negação, o contraditório ou até mesmo o conflito, também constituem potencialidades para o desenvolvimento. A complexidade e a contradição são elementos enfatizados pelo aporte teórico da Rede de Significações (Rossetti-Ferreira, Amorim, Silva \& Carvalho, 2004) sobre o processo de desenvolvimento humano e identificados em diferentes estudos que focalizam a interação entre pares (Amorim, 2013; Amorim, Costa, Rodrigues, Moura \& Ferreira, 2012; Costa \& Amorim, 2015; Saulo, Rossetti-Ferreira \& Amorim, 2013; Scorsolini-Comin \& Amorim, 2010).

Ainda é preciso mencionar sobre a atribuição de significado às ações na interação de pares que definem a forma pela qual a criança participa no contexto social. Ao se olhar para esse episódio na contextualidade de uma sala de aula, em um processo de escolarização, identifica-se que, ao final dele, às ações (particularmente) de Ivan foram atribuídos significados que repercutiram diretamente na forma pela qual essa criança vai participar das atividades em sala de aula. Conforme nota de campo, esse episódio ocorrido logo no início do ano contribuiu para que houvesse a decisão sobre a permanência constante de uma monitora ao lado de Ivan na sala de aula. Para além, define também o papel pedagógico desse adulto (prevenir que a 'mordida' ocorra novamente e ensinar Ivan as regras sociais) e com ele, constrói a identidade de Ivan dentro do contexto desse grupo de crianças, representando elementos que circunscrevem a vivência dessa criança em sala de aula.

Em síntese, quando se analisam os episódios do mês de março se observa que, tanto pela perspectiva quantitativa quanto qualitativa, há, por parte dos pares, pouco envolvimento ou reciprocidade no anseio do fazer conjunto. As corregulações são marcadas pela ausência de 
envolvimento direto (primeiro episódio) ou pela negação deste fazer (segundo episódio). Entretanto, considerando as possibilidades de criações de Zonas de Desenvolvimento Proximais, tais corregulações propiciaram potenciais de aprendizagem, tanto no âmbito da realização de atividades ligadas a rotina escolar (episódio "Fazendo parte da rotina da escola”), quanto e principalmente, na construção de rotinas culturais de pares (episódio "Vamos brincar de dormir") e, portanto, constituem-se em possibilidades para o desenvolvimento de Ivan.

Ao longo do ano, as interações foram se transformando. Na quantidade, há uma maior incidência de corregulações em atividades conjuntas e, em específico, iniciadas pelos pares (total igual a dez em agosto), apontando para um maior interesse dos pares na presençalações de Ivan. $\mathrm{Na}$ especificidade do processo interativo, no mês de agosto identifica-se a existência de elementos inéditos, como a utilização de um maior reportório de gestos na construção da comunicação, sendo possível identificar que a criança utiliza de processos diferentes para entender a intenção do outro. As crianças, nos momentos em que procuram por Ivan, chamam-no para brincar ou buscam sua atenção lhe mostrando algo, especialmente em contextos fora da sala de aula (playground). Todavia, as corregulações ainda deflagram imitações com características de uma cópia simultânea, frequentemente intercaladas com as próprias ações de Ivan, em uma ambiguidade própria do processo (Vasconcellos \& Valsiner, 1995). Tais situações se apresentaram em episódios de curta duração, repetidamente atravessados pela ação da monitora que ora redirecionava a atenção de Ivan, ora mediava a atividade em andamento.

\section{Ivan em: "Pode deixar, a gente se entende"}

\section{Data: 21 de Agosto de 2014, gravação (2) aos 0’32'.}

Contexto: Ivan e os demais colegas (dezenove ao todo) estão em roda discutindo as regras para irem ao Espaço Cultural. A professora, que está sentada no sentido oposto ao do grupo de crianças em foco, está explicando como é que os alunos devem se comportar durante a atividade que vão realizar. Ela conta com a ajuda de duas monitoras de sala, ambas sentadas perto de Ivan (identificado por uma flecha).

Descriçãa do episódio: Ivan, que está sentado ao lado direito de Nicolas, olha para o colega e começa a lhe fazer cócegas. Nicolas ri, reagindo ao estímulo do contato físico, segura as mãos de Ivan e com voz mansa pede para que Ivan pare. A monitora da turma, sentada atrás das crianças, segura a cabeça de Ivan, chamando sua atenção e fala para Ivan parar e prestar atenção. Ivan que mantémo olhar no colega retira a mão da monitora e faz cócegas no colega novamente. Dessa vez, Nicolas franze a testa, retrai o queixo na direção do pescoço, gesticula um não com as mãos. Ivan para, olha para a monitora e olha nos olhos do colega. Nicolas volta a sorrir e fala "Não pode". Ivan sorri de volta e faz cócegas pela terceira vez. Nicolas sorri, segura a mão de Ivan e fala "Não pode", novamente. Ivan para, olha para as mãos do colega segurando as suas, olha nos olhos de Nicolas $e$ 
volta a fazer cócegas. Os dois engajam em uma dinâmica que se repete com a mesma sequência de comportamentos (Ivan fazendo cócegas e Nicolas sinalizando 'não' ao mesmo tempo em que sorri). A monitora intervém e vira o corpo de Ivan na direção oposta a de Nicolas. Ivan permanece sentado. Nicolas busca por Ivan, o abraça e lhe faz carinho, puxando para perto de si. Ivan segura o braço de Nicolas e deita no colo do colega. Nicolas tenta puxar seu braço, num movimento de vai e volta, mas Ivan segura seu braço. Ivan se levanta, olha para o colega, sorri, puxa seu braço. Nicolas sorri e mantém o movimento de vai e vem. A monitora intervém, separa Ivan de Nicolas novamente, virando Ivan em direção à professora. Ivan acaricia o rosto de Nicolas, ao mesmo tempo em que olha para o colega. Nicolas o abraça e sorri. Nicolas busca o olhar de Ivan enquanto o abraça. Ivan e Nicolas trocam olhares e Ivan balbucia algo. Nicolas abaixa seu braço e olha para Ivan, que por sua vez está olhando para a perna de Nicolas. Nicolas vira a perna e aponta para seu pé, mostrando seu tênis, Ivan olha para os pés de Nicolas, olha para seu joelho, apalpa-o e olha diretamente para o colega. Nicolas apalpa o próprio joelho e Ivan mantém seu olhar nas mãos do colega. Ivan toca o joelho de Nicolas, tenta tirar sua mão de cima do joelho, olha para o colega, para a monitora que está falando pra ele parar, olha para Nicolas novamente. Ivan para e olha para o tênis de Nicolas e puxa seu cadarço. Nicolas segura sua mão, Ivan para e segura o cadarço do tênis. Ivan olha para o colega por um tempo e se vira em direção à roda.

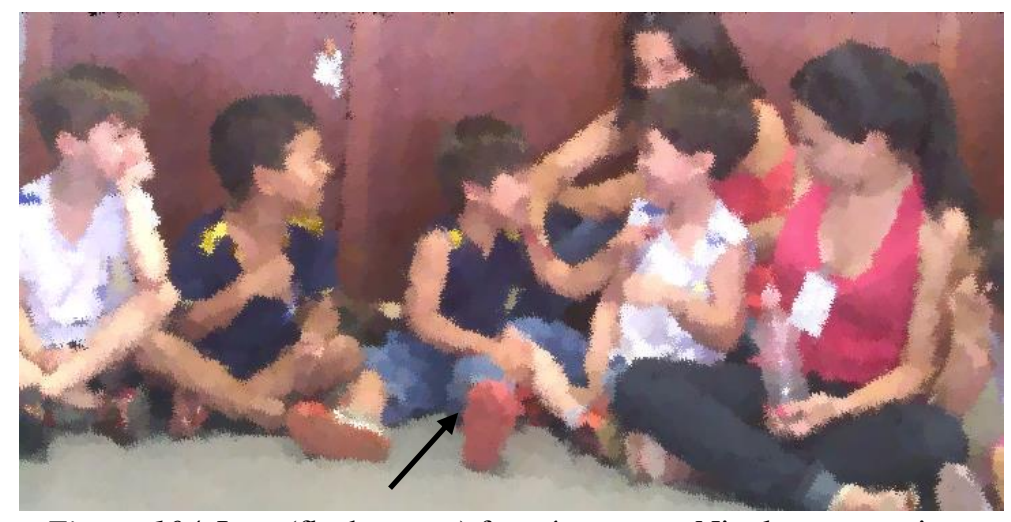

Figura 104. Ivan (flecha preta) faz cócegas em Nicolas e a monitora pede que ele pare.

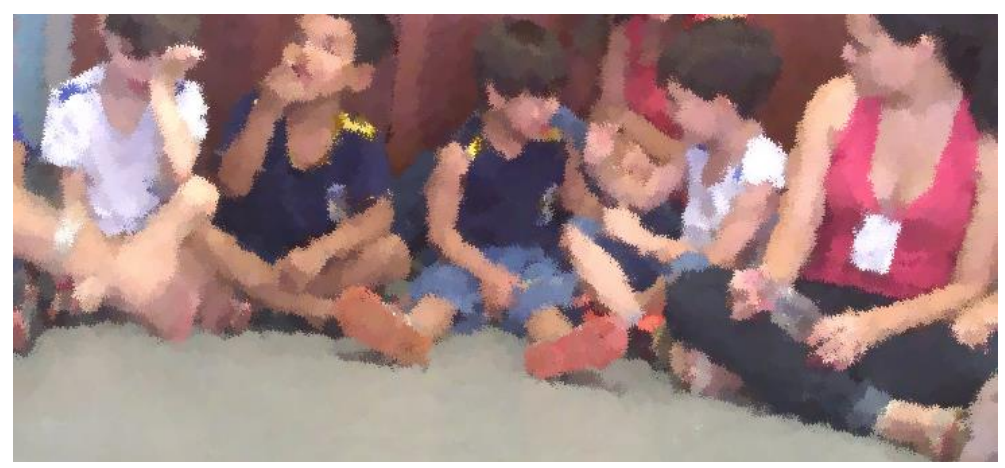

Figura 105. Nicolas sorri e pede que Ivan não faça cócegas. 


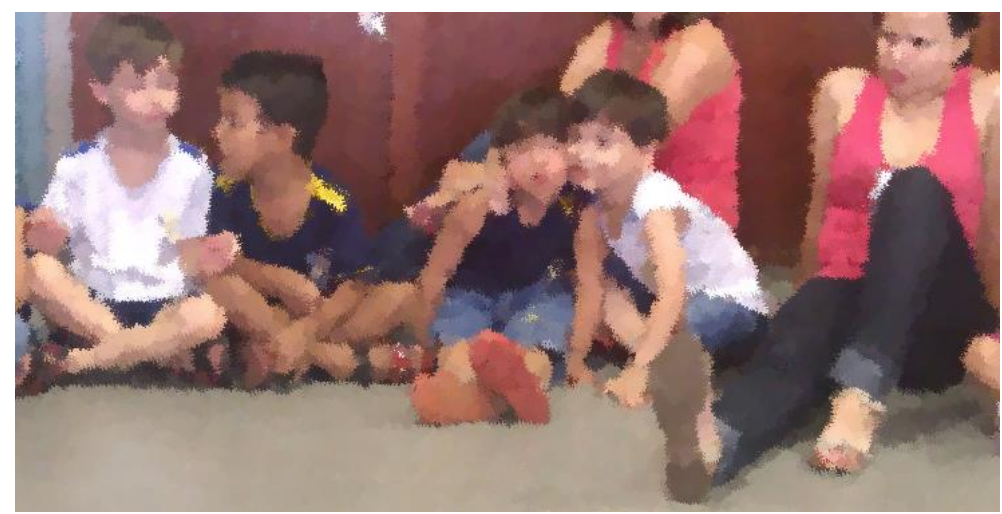

Figura 106. Nicolas abraça Ivan

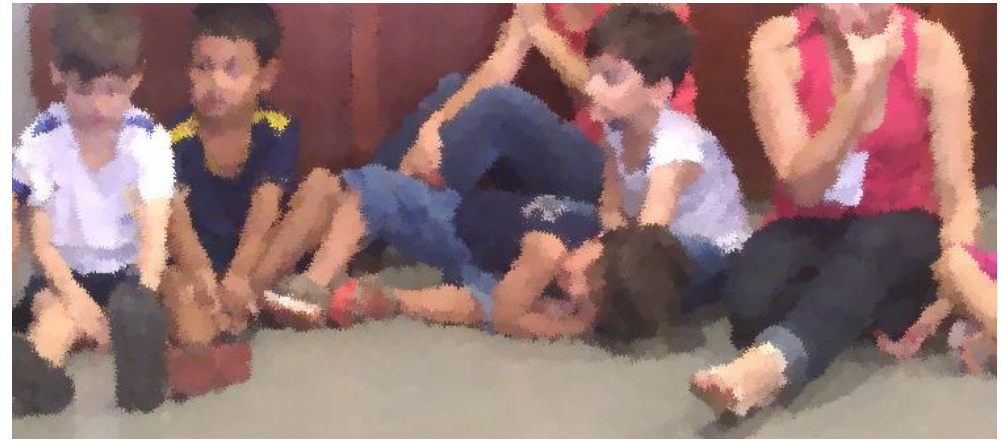

Figura 107. Ivan deita no colo de Nicolas.

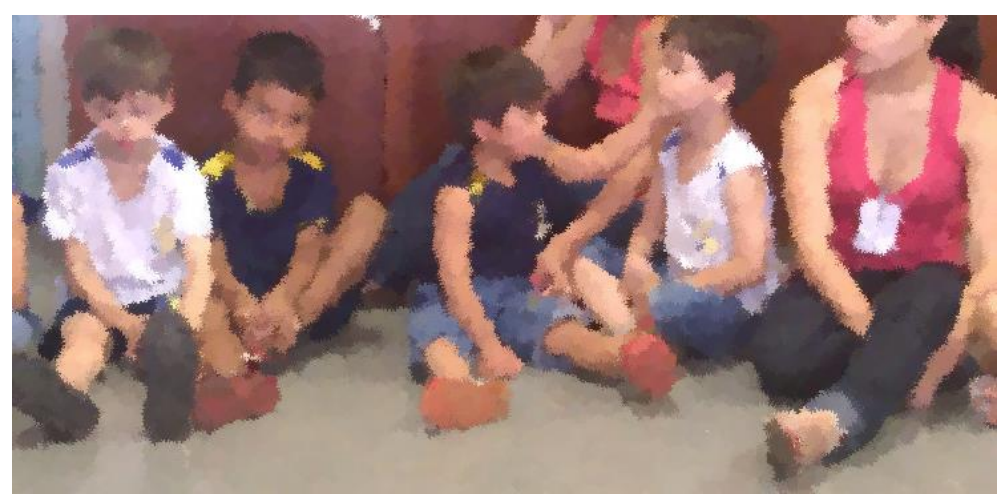

Figura 108. Ivan faz carinho no rosto de Nicolas.

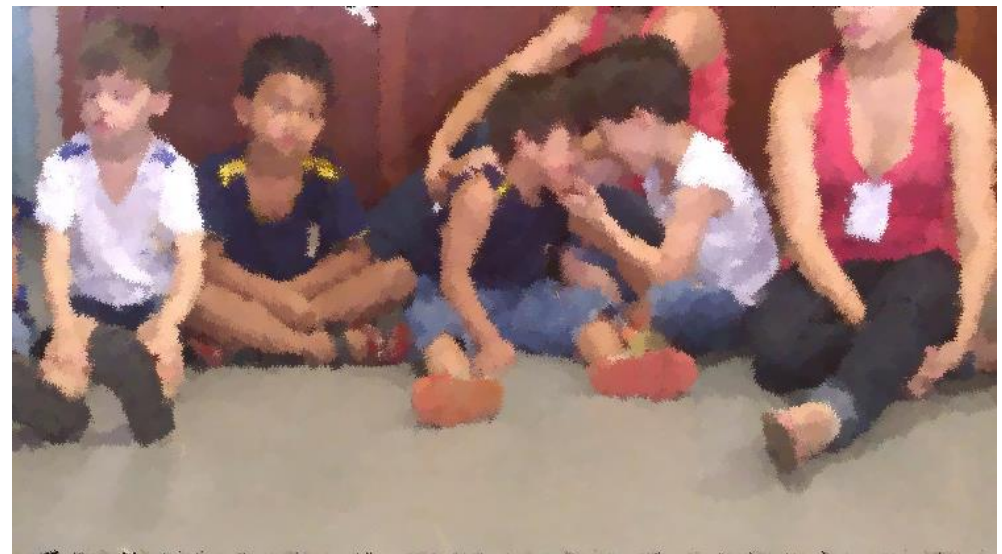

Figura 109. Ivan e Nicolas trocam olhares e carinho. 
O contato físico que demarca o início do processo, advêm de Ivan, mas o ritmo estabelecido no processo de interação é compartilhado entre as duas crianças através de gestos similares (e.g. afago na face, cócegas, toque), fenômeno encontrado em outros estudos sobre processos de significação entre crianças pequenas (Amorim, 2008; Bruner, 1997; Lucena, 2010; Pedrosa \& Carvalho, 2006). As regulações de comportamento neste episódio estão relacionadas à construção de caminhos para se entrarlestar em contato com o Outro, mesmo que nessa construção Nicolas conte com a fala, enquanto que Ivan apenas com o aparato gestual.

Ao esticar os braços em direção ao pescoço de Nicolas e mexer com os dedos contra a sua pele, infere-se que Ivan fez a tentativa de estabelecer com o par uma atividade conjunta (brincar de fazer cócegas) e nas respostas do par se deram as possibilidades de construção da comunicação. Em resposta ao estímulo físico de Ivan, Nicolas faz uso da fala e de gestos (segurar as mãos de Ivan, fazer sinal de não) para conter as cócegas, explicitando o uso de diferentes recursos para transmitir a ideia de negação ou contrariedade à intenção de Ivan. Contudo, ao mesmo tempo em que se utiliza de tais recursos verbais e gestuais, Nicolas mantém uma expressão faciallcorporal de contentamento (sorriso, mãos relaxadas e baixa guarda, posicionamento do corpo em direção ao colega), que pode ter sido entendida por Ivan como uma autorização para a continuidade da dinâmica de brincadeira. Essa ambivalência de informações demanda um sofisticado processo de análise das ações do Outro, uma vez que para além de identificar os diferentes e contraditórios tipos de comportamentos, Ivan necessita avaliar sua sequência e pertinência no contexto dado, a fim de escolher a resposta mais adequada.

Aqui, diferente do episódio do dia 27 do mês de março, Ivan já é capaz de responder a essas ações mostrando um reportório gestual mais ampliado, com evidências de um processo de classificação de ações - quando uma ação é reconhecida pelos seus padrões em uma determinada categoria de ações (Rumelhart \& McClelland, 1986, conforme citado em Uithol \& Paulus, 2013), e seleção de respostas - uma forma de compreensão das ações do Outro em que as características do ambiente são codificadas e, após uma decisão cognitiva, uma resposta adequada é gerada (De Jaegher, Di Paolo \& Gallagher, 2010). Pode-se observar esses dois processos através das respostas de Ivan frente às diferentes e ambíguas expressões de Nicolas. Quando Nicolas 'franze a testa, retrai o queixo na direção do pescoço, gesticula um não com as mãos' Ivan para, mostrando evidências de que ele possivelmente reconhece tal expressão enquanto um comportamento de negação a sua ação anterior. Ele busca então outras informações do meio 'olha para a monitora e olha nos olhos do colega' e quando identifica que Nicolas 'volta a sorrir' comportamento que usualmente é significado como um sinal positivo e, portanto, pertencente a uma outra categoria de 
comportamentos, 'Ivan sorri de volta e faz cócegas'. Ivan responde de acordo com a sequência de pistas oferecidas pelo meio nesse processo interativo.

Na sequência, é Nicolas quem busca por Ivan e, através do contato físico, o atrai para perto de si. A troca de carícias vai, ao longo do episódio transformando-se em atividade conjunta ('Ivan segura o braço de Nicolas e deita sobre ele no colo do colega. Nicolas tenta puxar seu braço, num movimento de vai e volta, mas Ivan segura seu braço. Ivan se levanta, olha para o colega, sorri, puxa seu braço. Nicolas sorri e mantém o movimento de vai e vem'), que é eventualmente interrompido pela monitora. Ao mesmo tempo em que Ivan está simultaneamente copiando os comportamentos de Nicolas, está fazendo parte da construção da atividade conjunta, propriedade da imitação descrita por Vasconcellos e Valsiner (1995).

$\mathrm{Na}$ retomada do contato após a interrupção do adulto, nota-se que gestos indicativos e, principalmente, o contato visual orientam as ações das crianças. A sequência de comportamentos, em um ritmo quase que sincrônico, mostra a continuidade, sem incongruências, desse processo comunicativo. Em estudo sobre os processos de construção de comunicação de crianças entre 636 meses, Pedrosa e Carvalho (2006) evidenciam o papel construtivo das interações livres de crianças para a diferenciação de códigos comunicativos dentre os gestos, ações ou segmentos linguísticos contidos no processo interativo. Tal estudo discute que a regulação e as sucessivas corregulações constituem requisitos para o processo comunicativo, destacando o papel do contato visual e do sorriso na transformação dos signos expressivos em uma comunicação referenciada. Seriam imersas nessas regulações, que residiriam as possibilidades da reconstrução de significados de códigos comunicativos, pertencentes exclusivamente à cultura de pares criado pelas crianças.

Dessa forma, parte das conquistas de Ivan advém da corregulação do seu parceiro. Diferente do episódio do dia 27, Nicolas, através de suas ações, explicita a Ivan quais são as suas intenções ao invés de simplesmente reagir ao comportamento destes. É preciso considerar ainda o restante do episódio, em que essas crianças vão, por cerca de mais um minuto, trocar carícias, contatos visuais, gestos e compartilhar uma forma de estar conjunto, que não necessariamente demandou um processo de verbalização. Pode-se ver então, na comparação destes dois casos, que quando há um envolvimento da criança, mesmo que seja contraditória às intenções da criança pivô, existe a possibilidade de um acordo no processo comunicativo, e consequentemente, possibilidades de Ivan testar as suas hipóteses sobre o entendimento das ações do outro.

Concluindo, no mês de agosto a maior reciprocidade dos pares no fazer conjunto com Ivan destacam a relevância e as contribuições do compartilhamento de significado para o processo de interação. As transformações nas interações dos pares entre esses meses dizem respeito à disponibilidade, ao interesse ou ainda, ao envolvimento dos pares para a ação conjunta com Ivan. 
Essa disponibilidade possibilita a adequação dos instrumentos comunicativos (e.g., da fala para o gesto, o tempo de contato, a persistência do comportamento) e, consequentemente, maiores possibilidades do compartilhamento na construção de significado.

Em dezembro, no final da coleta de dados, as corregulações de comportamento com atenção conjunta ou compartilhamento de objeto ocorreram num total de dez episódios, sendo seis iniciadas por Ivan e quatro pelos pares e envolvem, principalmente, atividades coletivas (faz de conta e atividades livres no playground), negociações no uso de objetos e em conflitos com pares.

Nos episódios do mês de dezembro, a imitação ainda aparece demarcando a estrutura das corregulações de comportamento e se, em março, a imitação de Ivan consistia em uma cópia simultânea que, gradativamente, apresentou maior sofisticação, em dezembro ela vem acompanhada da contemplação, sendo utilizada em contextos e situações mais complexas, conforme é possível observar no episódio “O que é isso aí? ”, datado de 01 de dezembro 2014, apresentado na fase II de análise dos dados (ver página 139).

\section{Ivan em "Deixa ele, ele ainda não sabe!"}

\section{Data: 12 de dezembro de 2014, gravação n.2}

Contexto: Ivan e seus colegas, (ao todo dezenove crianças de sua sala e duas outras salas de $1^{\circ} \mathrm{e}$ $2^{\circ}$ período) estão brincando no parquinho da escola. Ivan está ao redor do escorregador, quando avista um grupo de meninos brincando com uma garrafa PET, jogando-a de lado a lado.

Imediatamente ele se levanta e vai em direção às crianças.

Descrição do episódio: Um grupo de crianças está brincando com uma garrafa PET vazia, jogando-a de lado a lado na área cimentada do parquinho, chutando a garrafa uns para os outros. Ivan, que está sentado debaixo do escorregador, avista as crianças e imediatamente levanta-se e corre em direção a elas. As crianças jogam a garrafa PET em direção ao escorregador. Pedro recebe a garrafa jogada, coloca-a no chão e a chuta em direção ao muro. Os demais colegas correm em direção à garrafa. Ivan segue os colegas, também correndo. Uma criança de outra sala pega a garrafa e a arremessa em direção oposta. Todas as crianças se viram e correm em direção à garrafa PET. Ao mesmo tempo, as crianças gritam “Aqui, aqui!'. Armando (criança de outra sala) pega a garrafa PET com as mãos quando Ivan se aproxima dela. Armando vira-se em direção oposta e esquiva-se das mãos de Ivan que tenta alcançá-la. Neste momento, Armando está com a garrafa PET em mãos, correndo em círculos no parquinho, fugindo de Ivan. A criança mantém as mãos para o alto, olha para Ivan, olha para frente, corre, olha para Ivan, mantém a garrafa PET acima. As demais crianças observam o seu comportamento. Armando arremessa a garrafa e todas as crianças correm em direção a ela para chutá-la. O grupo de crianças permanece chutando a garrafa, arremessando-a, enquanto Ivan percorre em torno delas, também tentando alcançar a garrafa. Os chutes e arremessos continuam por volta de mais 32 segundos. Em nenhum momento, Ivan consegue se aproximar do objeto, visto que as crianças, além de serem maiores que ele, agem de forma mais rápida para chegar à garrafa. Aos 02:03min Ivan tem a sua chance. Ele passa na frente de César, agacha-se em direção à garrafa e a segura com as mãos. 
Nesse momento, a garrafa encontra-se justaposta aos pés de uma criança de outra sala, aqui denominada Paulo. Paulo pisa na garrafa, segurando-a contra o chão e impedindo que Ivan a segure com as mãos. Imediatamente Pedro vem em direção às crianças e fala: "Deixe ele pegar!" - gritando. "Ele não sabe! Deixa ele pegar, ele não sabe. Deixa!" Porém, Paulo continua pisando com os pés na garrafa. Agora, César também pisa, impedindo que Ivan consiga segurar a garrafa com as mãos. Neste momento, outra criança da sala de Ivan também vem ao seu auxílio e grita para os colegas Paulo e César - "Deixa, deixa ele pegar!”. Pedro tenta puxar César pelas costas, tirando-o de cima da garrafa e, consequentemente, tirando-o de cima de Ivan. Paulo retira os seus pés de cima da garrafa e se afasta da cena. César permanece, segurando no corrimão instalado no muro e pisando sobre a garrafa, impedindo que Ivan a retire do chão. Pedro vem e segura César pelo pescoço, puxando-o em sentido contrário ao da garrafa. César então desprende-se do corrimão do muro e afasta-se, liberando a garrafa para que Ivan a segure. Ivan então, já sentado no chão, segura a garrafa, olha para ela e olha para Pedro. Pedro fala 'joga a garrafa Ivan, joga pra gente!' Ivan se levanta, arremessa a garrafa e corre em direção a ela conforme faz também o restante dos colegas. As crianças voltam a brincar com a garrafa.

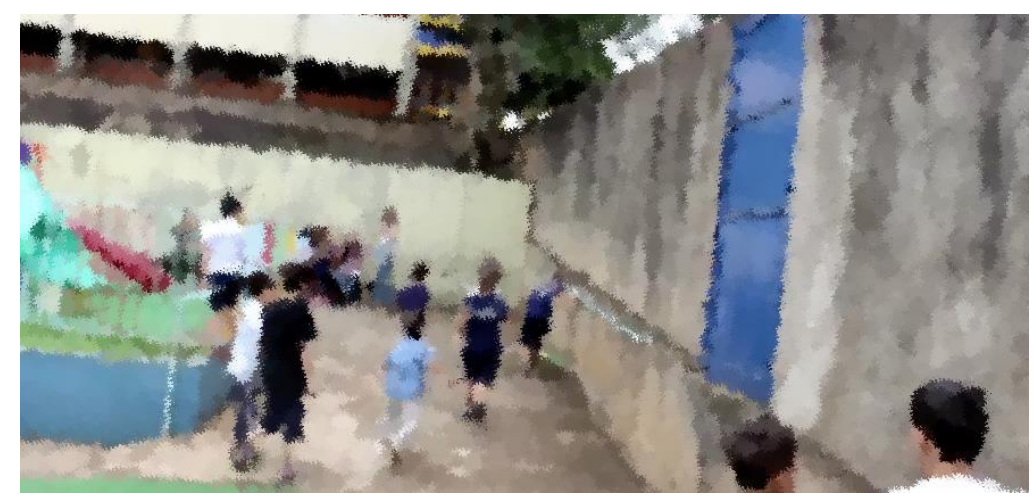

Figura 110. Ivan (camisa azul clara) corre em direção ao grupo de crianças brincando com a garrafa PET.

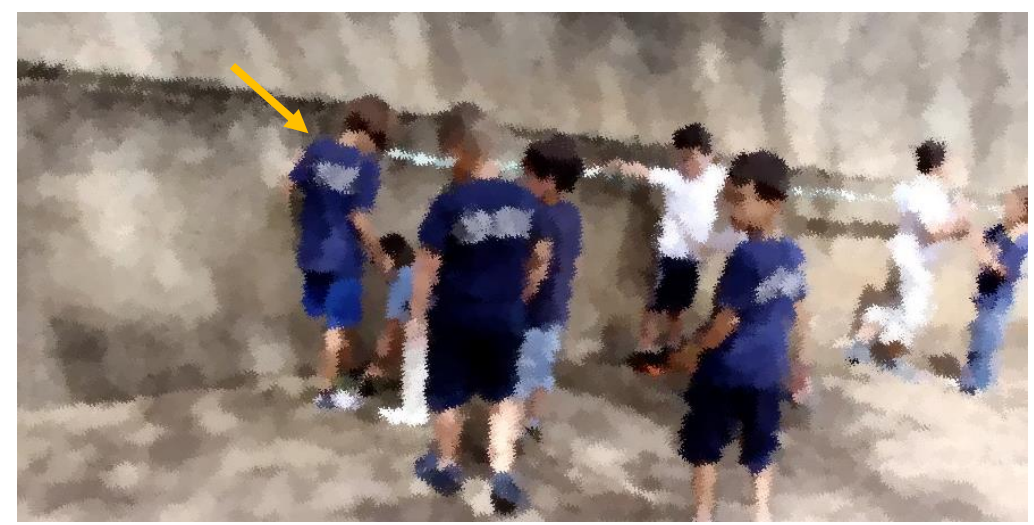

Figura 111. Paulo (seta amarela) pisa na garrafa, impedindo que Ivan a pegue. 


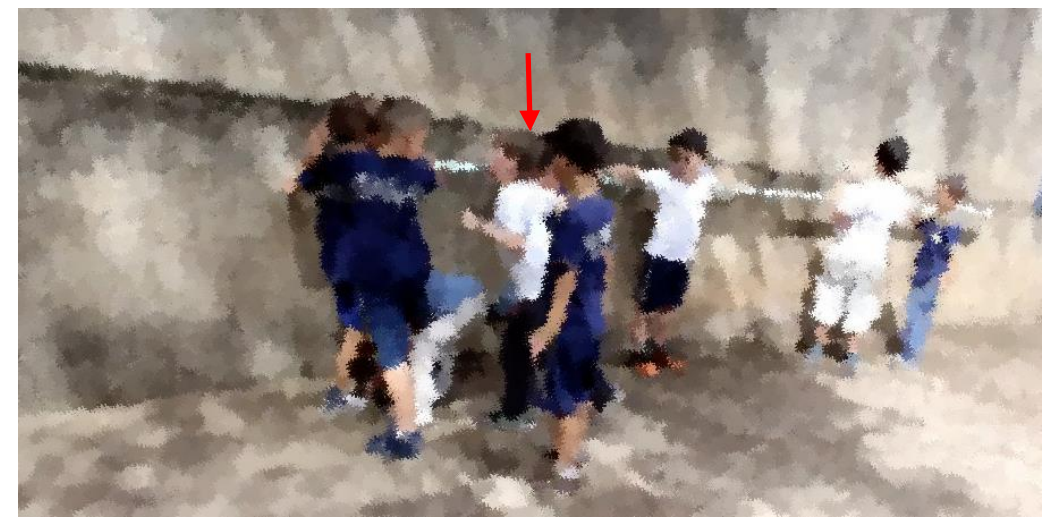

Figura 112. Pedro (seta vermelha) grita com o colega solicitando que ele deixe Ivan pegar o objeto.

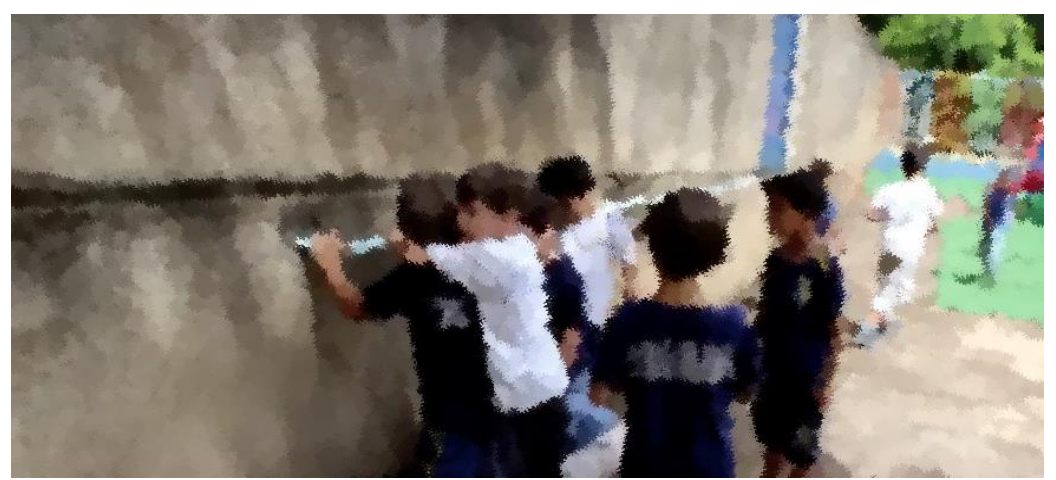

Figura 113. Pedro segurando César, puxando-o para longe de Ivan.

O controle motor já permite a Ivan estruturar seus movimentos a fim de concretizar uma imitação imediata, corroborando com a ideia de que "quanto mais a criança passe a dominar os signos culturais e desenvolver os aspectos cognitivos, mais o gesto motor tende a se reduzir enquanto agitação, ganhando em refino e qualidade motora autônoma” (Gratiot-Alfandéry, 2010. p.38). Bruner (1997) em seus estudos, já apontava que interações sistemáticas em ambiente culturalmente situado são fundamentais para o estabelecimento da ampliação e significação do mundo. Contudo, pouco ainda era sabido sobre como essas interações sistematizadas realmente ocorriam para a criança com déficit intelectual, cujo desenvolvimento da linguagem verbal está frequentemente em desvantagem comparado a outros pares de mesma idade, o que era o foco de Bruner.

Neste episódio, é a possibilidade da imitação que leva Ivan a participar da atividade coletiva em curso, mas é na mediação do par, não apenas junto a Ivan, mas junto aos demais pares, que Ivan atua na condução da atividade. É na negociação e conflito corporal, no comando verbal com indícios de intencionalidade que o par abre espaço para a ação de Ivan e, além, o instrui em como executar tais ações autonomamente. A aprendizagem que circunscreve o episódio também é de natureza social, na construção da atividade conjunta livre. Entretanto, na análise das possibilidades de criação de Zonas de Desenvolvimento Proximais, entende-se que a ação do par, marcada pela 
instrução verbal é o elemento que instrui diretamente a realização de uma atividade que Ivan poderia (ou não) realizar de acordo com a estrutura da brincadeira. A relação com o desenvolvimento encontra-se na natureza da atividade (brincadeira), que permite que Ivan experimente um dado modelo, diferente de si, mas que é parte da sua rede de experiências sociais e no jogo de papéis que, através da ação do par, permite que Ivan experimente a condução de uma atividade de grupo. As interações vão, portanto, ficando mais elaboradas e permitindo que Ivan associe diferentes tipos de comportamento ao seu repertório gestual e ao repertório de signos que vão codificando o mundo.

Ao se analisar as interações de março a dezembro, identifica-se que, ao longo do tempo, as aprendizagens não se diferenciam no seu objeto, como no caso de Inácio. Os episódios, tanto do início quanto do final do processo de coleta de dados, trazem aprendizagens relacionadas à vida em grupo, aos aspectos sociais do processo de escolarização, muito embora em outros meses de registro, aprendizagens relacionadas a atividades específicas tenham também emergido. Contudo, a forma como essas aprendizagens foram construídas diferenciou-se ao longo do tempo e um dos elementos considerado importante para essa transformação foi o envolvimento dos pares na construção de atividades conjuntas. Ao se comparar os episódios do início da coleta de dados com os do final, se observa que as possibilidades de os pares entenderem os gestos e as ações de Ivan vão sendo consideravelmente ampliadas. Pedro, que nas filmagens do mês de março não compreendia a intenção de participação ou de iniciar uma atividade conjunta partindo de Ivan, em dezembro, além de entender a intenção de participação dessa criança em uma brincadeira em curso, consegue também identificar quais são as demandas de Ivan para que esse processo ocorra, levando-o a intervir de forma intencional junto aos demais colegas que ainda não conhecem essa criança e suas demandas.

\section{Estudo de caso Amanda}

No mês de maio (início das coletas de dados no estudo de caso da Amanda), as corregulações de comportamento com atenção conjunta ou compartilhamento de objeto aconteceram circunscritas em diversos contextos e em situações, tais como nas atividades coletivas na sala de aula $(n=10)$; nas brincadeiras livres no pátio $(n=5)$; e, nos momentos de alimentação no refeitório $(\mathrm{n}=1)$. Em quatro dos dezesseis episódios de corregulações de comportamento identificou-se a presença de conflito entre as crianças, que disputaram entre si a posse de brinquedos. Na ocasião do conflito, a interação foi imediatamente interrompida pelas monitoras, ou mesmo pela professora e Amanda foi reposicionada em outro grupo de crianças. 
A despeito da diversidade circunstancial, as corregulações de comportamento são marcadas por processos de mimetismo (Wallon, 2008), presentes na totalidade de episódios e as aprendizagens oportunizadas estão, particularmente, relacionadas à construção de atividades conjuntas e da participação de Amanda nos espaços coletivos. A estrutura das corregulações é sustentada pela manifestação de gestos e expressões faciais e em sete dos dezesseis episódios é identificado o contágio emocional (Wallon, 2008) enquanto movimento que guia o processo imitativo. O contágio emocional já havia sido apontado como um fator de relevância na análise das interações do caso Amanda, conforme os resultados apresentados na fase II. Dessa forma, com o intuito de ampliar a perspectiva de análise das corregulações de comportamento envolvendo essa criança pivô, foi escolhido um episódio sem o contágio emocional como recorte para apresentação dos resultados.

\section{Amanda em: "Explorando meu almoço"}

\section{Data: 28 de maio de 2014, gravação n. 2 aos 19'09'”}

Contexto geral: Amanda e os demais colegas de três turmas estão no refeitório almoçando. Amanda está sentada do lado esquerdo de Jéssica e à direita de Gabriela. A comida é servida pela própria professora e monitoras da turma, em pratos de plástico. As crianças comem sozinhas sem a supervisão constante do adulto. As crianças ficam no refeitório por aproximadamente trinta minutos, mas caso demandem mais tempo para se alimentarem, as monitoras auxiliam no processo.

Descrição do episódio: Amanda está segurando uma colher cheia de comida com a mão direita. Jéssica que está logo ao seu lado pega um pedaço de couve desfiada com a mão, ergue o braço e posiciona a couve em sua própria boca. Amanda olha para a colega. Jéssica come a couve. Amanda larga a colher com comida, pega um pedaço de couve desfiada com as mãos e imita os gestos de Jéssica, comendo a couve. As demais crianças olham para Amanda, conversam e continuam comendo com as colheres. Jéssica mais uma vez usa as mãos para pegar um pedaço de couve de seu prato, ela olha para Amanda e brinca com esse pedaço de couve. Amanda olha para o seu prato, para sua colher, para os colegas, come com a colher e sorri. Jéssica pega um pedaço de couve, erguendo-o para o alto e coloca-o novamente na boca. A professora vem em direção a Amanda, limpa o seu nariz e depois sai de cena. Amanda copia o gesto de Jéssica, também colocando um pedaço de couve em sua boca. Olha para Jéssica e sorri. Jéssica olha para a câmera e sorri, levanta e pega um pedaço de couve do prato de Amanda. Amanda olha para as mãos da colega. A monitora coloca Jéssica sentada novamente na cadeira. Jéssica está com um fio de couve nas mãos. Amanda observa as mãos de Jéssica. Jéssica puxa mais um fio de couve, ergue-o para o alto e coloca na boca e olha para Amanda. Amanda mantém o olhar na colega, em suas mãos e sorri. Imediatamente, Amanda pega o fio de couve com os dedos, ergue-o para o alto e o traz em direção à boca. Jéssica observa Amanda fazendo o processo, olha para a câmera, sorri e depois repete o movimento, erguendo um pedaço de couve e o trazendo em direção à boca. A monitora tira Jéssica da mesa. Amanda olha para a colega indo embora, olha para os demais colegas e permanece sentada na sua cadeira. Amanda olha para as demais crianças, segura a sua colher e volta a comer com a esta. 


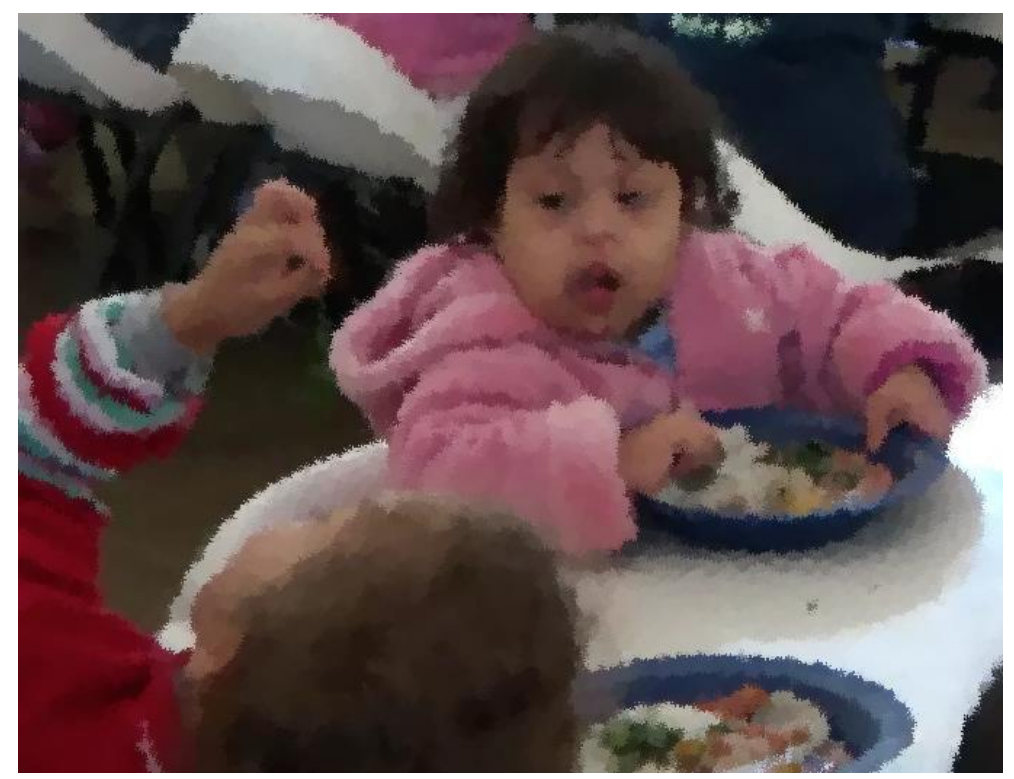

Figura 114. Amanda olha para Jéssica enquanto ela coloca um fio de couve na boca.

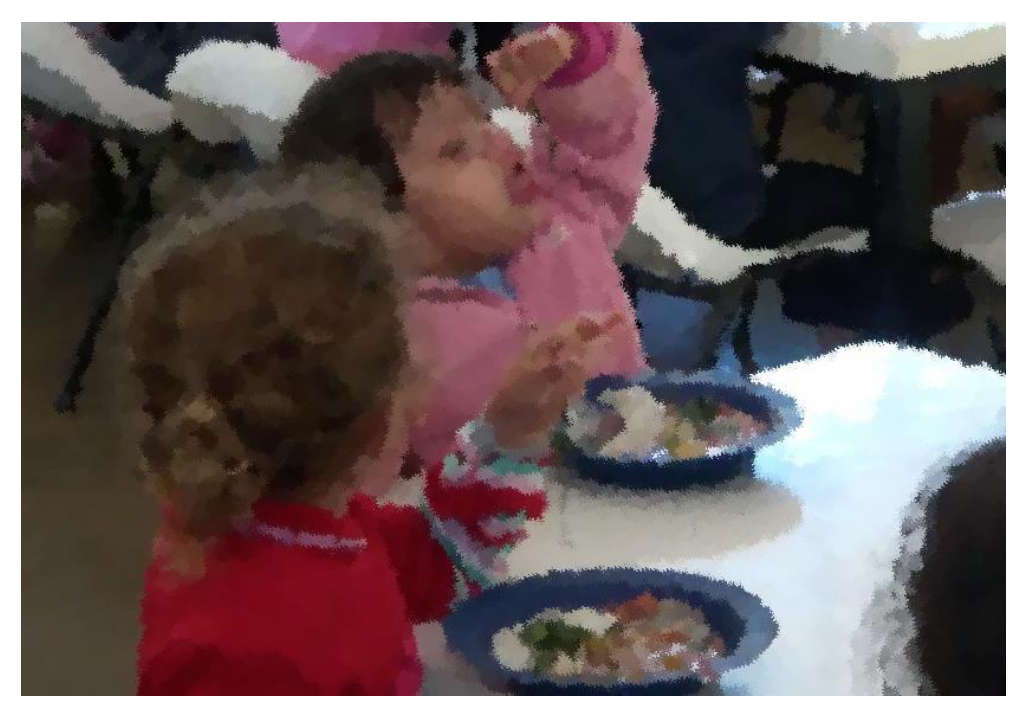

Figura 115 Amanda imita o gesto anterior de Jéssica. Jéssica olha para Amanda enquanto ela coloca um fio de couve na boca.

As imitações simultâneas que ocorrem ao longo desse mês e, em particular neste episódio, são entendidas como um processo em que essa criança pivô toma o outro como um complemento de si, provocando a identificação com os pares com os quais ela mantém contato. Esse processo de identificação é descrito no quarto estágio de desenvolvimento proposto por Wallon (1975) e seria, segundo Oliveira (2011), o momento no qual as crianças começariam a "agrupar dados intuitivos que progressivamente lhe possibilitam apreender a experiência imediata como fonte de possibilidades" (Oliveira, 2011, p. 52). É justamente a sua capacidade de imitar e o fato de a imitação ocorrer imediatamente após o comportamento do par, que permite que as crianças 
elaborem (nas poucas situações em que estão interagindo sem a presença do adulto) a experiência conjunta em uma atividade coletiva em que significados são compartilhados, criando cultura de pares (Corsaro, 2003; Lucena, 2010).

Neste episódio, assim como nos estudos de Pedrosa e Carvalho (2006), o compartilhamento de significado é enfatizado por meio de expressões faciais específicas (manutenção do olhar e o sorriso), que criam ritmo (Amanda olha, Jéssica executa - Amanda executa, Jéssica olha) e o feedback necessário (manifestado principalmente pelo sorriso mútuo entremeio aos comportamentos copiados) para a construção da atividade de brincadeira entre as crianças. A estrutura das corregulações de comportamento no início das coletas de dados é demarcada, portanto, por gestos e expressões faciais e, por meio desses, a criação de rotinas culturais de pares.

O comportamento imitado em si (colocar comida na boca usando as mãos) muito provavelmente não se configura em uma aprendizagem nova para Amanda, pelo contrário, já estão incorporados nos comportamentos da criança os modos convencionais de alimentação (comer com talheres). Afirma-se isso a partir do próprio episódio pois, no momento em que Jéssica é retirada da mesa, Amanda volta a comer com a colher, nitidamente separando o que era a brincadeira e o que é o sistema convencional aceito. Dessa forma, compreende-se que o processo de aprendizagem está na possibilidade de transformar gestos aleatórios em atividade de brincadeira, através da ação do par. O par, neste contexto, inicia e conduz o processo, e quando interrompe momentaneamente o movimento de cópia 'Amanda olha para o seu prato, para sua colher, para os colegas, come com a colher e sorri', é também o par que, persistindo na ação, fornece espaço para a continuidade da dinâmica; a ação do par é ativa no processo de construção da brincadeira.

Segundo Marjanovic-Shane (2010), frequentemente se tem olhado para a brincadeira enquanto proveniência do desenvolvimento individual e processo particularmente dominante na infância, principalmente em decorrência das suas contribuições para a ampliação da função simbólica. Contudo, Marjanovic-Shane examina um outro elemento da brincadeira: o significado que ela cria entre aqueles que brincam e o valor da ação em si para o desenvolvimento das emoções, um aspecto da teoria de Vygotsky que tem recebido pouca atenção. A perspectiva de análise nos trabalhos de Marjanovic-Shane (2008; 2010) explora o aspecto emocional que a brincadeira produz, apontando que a atividade de brincar conjunto cria a 'emoção real', ou 'emoção sincera' da qual Vygotsky (1999) atribui o efeito catártico da arte para o ser humano enquanto fenômeno que permite a superação de si mesmo. Neste sentido, Marjanovic-Shane defende que a brincadeira em si, independente do seu conteúdo, transforma o sujeito em coautor das emoções de outro (e vice-versa) e essa experiência traz para os sujeitos um sentimento novo, uma experiência que só é possível na ação conjunta. 
Cabe aqui salientar que a emoção, embora pouco explorada, foi um dos elementos de interesse de Vygotsky e que esteve entremeado em toda sua construção teórica, principalmente no início e ao final de seus trabalhos. Para Vygostky (2001) "a reação emocional enquanto reação secundária é um poderoso organizador do comportamento" (p.137), não é um agente menor que o pensamento e,

“(...) a brincadeira é a melhor forma de organização do comportamento emocional. A brincadeira da criança é sempre emocional, desperta nela sentimentos fortes e nítidos, mas ensina a seguir cegamente as emoções, a combiná-las com as regras do jogo e o seu objetivo final. Assim, a brincadeira constitui as primeiras formas de comportamento consciente que surgem na base do instintivo e do emocional" (p.147).

Neste episódio específico, a Zona de Desenvolvimento Proximal acontece, portanto, pelo processo de identificação com o par (Jéssica), que possibilita Amanda (re)criar na brincadeira, no compartilhamento de significado, a superação do próprio sentir (sentir enquanto propriedade individual) para o sentir conjunto, "liberando novas energias que criam e sustentam uma interação dialógica. Essa é a completude do Eu no Você, com Você e por Você, juntos nos tornando (co)criadores e coautores de entendimento" (Marjanovic-Shane, 2010, p. 58). Ressalta-se ainda, que essa é uma criança que mantém um olhar atento para as ações dos pares. Pode-se identificar em alguns $(\mathrm{n}=10)$ dos episódios de interação do mês de maio (como esse apresentado acima), a presença da contemplação antes da manifestação das cópias gestuais.

No decorrer do ano letivo as corregulações de comportamento vão se transformando, assim como nos casos Inácio e Ivan. Para Amanda, identificou-se um número maior de corregulações de comportamento no meio do processo de coleta de dados $(n .=25,56 \%$ a mais que em maio) e desse total, dez episódios foram iniciados pelos pares. Mais uma vez, a imitação é o elemento principal que inicia ou conduz o processo de corregulações, ocorrendo em todos os dias de registro, independente do espaço (e.g., sala de aula, pátio, refeitório e etc.). Em alguns casos (n=2), foi observado que Amanda selecionou a partir do grupo de crianças os comportamentos de um parceiro específico (Gustavo), sugerindo uma possível preferência por essa criança. No episódio "Aprendendo as regras do encaixe", discutir-se-á detalhadamente esse processo.

Ao longo de todo o mês foram identificados episódios com contágio emocional, bem como situações que se assemelham a apresentada pelo episódio "Explorando meu almoço" do mês de maio. Contudo, em setembro, identifica-se nas corregulações de comportamento com atenção 
conjunta ou compartilhamento de objetos um novo tipo de aprendizagem que está relacionada a uma atividade específica que faz parte da rotina de pares. E, mesmo acontecendo em apenas dois dos dezesseis episódios, julga-se relevante pela discussão de como as corregulações vão se transformando ao longo do tempo. Ainda, conforme já havia sido apontado na fase II de análise, as imitações até o presente momento ocorrem sempre na presença de um modelo.

\section{Amanda em: "Às vezes eu perco a paciência"}

\section{Data 10 de Setembro de 2014, gravação n.1 aos 2'50',}

Contexto geral: A turma está na sala de aula e a professora orienta a atividade entregando brinquedos específicos para cada grupo de criança. Amanda, Letícia, José, Isabela e Rafaela estão utilizando um brinquedo feito de garrafa PET e canudos de plástico. O objetivo do brinquedo é atravessar de lado-a-lado os canudos de plástico por meio de furos na garrafa PET, trabalhando a coordenação motora fina das crianças. A professora e as monitoras posicionam as crianças no canto esquerdo da sala de aula. A professora explica para o grupo de crianças o que fazer e as deixa sozinhas.

Descrição do episódio: Amanda é posicionada sentada à frente de Letícia e do lado direito de José. Amanda olha para os colegas que já iniciaram a atividade. Ela segura com a mão esquerda a garrafa PET perto do seu corpo e com a mão direita ela segura o canudo de plástico pela ponta mais afastada. Ela tenta colocar o canudo dentro da garrafa por meio do furo, mas o canudo dobra e não completa a entrada. Amanda olha para a criança a sua frente (Letícia). Letícia segura o canudo pela ponta mais próxima da garrafa, passando o canudo para dentro da mesma. Amanda olha para sua garrafa, a sacode, olha para Rafaela, reposiciona a sua mão no canudo, agora segurando-o pela ponta mais próxima a garrada e coloca-o para dentro. Amanda estende os braços para cima, balbucia 'aharrr' e olha para os pares, mostrando a garrafa para todos. Amanda sorri, olha para a câmera e volta a olhar para a garrafa. Ela então pega outro canudo $e$ começa novamente. Amanda olha para Letícia que, neste momento, brinca com os canudos e não com a garrafa. Amanda segura a garrafa e bate-a contra o chão na frente das crianças, chamando a atenção dos colegas. As crianças olham para Amanda, afastam-se e continuam a mexer com os objetos. A professora chama a sua atenção falando 'Amanda assim não, não é assim que brinca'. A professora senta perto de Amanda, coloca-a sentada perto de si e explica como colocar os canudos dentro da garrafa. Letícia olha para Amanda junto com a professora. A professora levanta e deixa Amanda junto as demais crianças. Amanda olha para Letícia, que abre a tampa da garrafa e começa a colocar os canudos lá dentro. Amanda tenta abrir a sua garrafa, mas não consegue, então ela se vira em direção à professora, aponta a garrafa em sua direção coloca as mãos na tampa e faz o movimento rotatório com os dedinhos, sem abrir a garrafa. A professora fala: 'você quer que eu abra a garrafa?'. Amanda balança a cabeça em sinal afirmativo e, então a professora abre a garrafa. Amanda volta a sentar-se junto aos colegas, olha para Letícia e começa a colocar os canudos de plástico dentro da garrafa. Letícia olha para Amanda e coloca seus canudos dentro da garrafa dela, as duas trocam de garrafa e continuam colocando os canudos (agora misturados) nas garrafas. Isabela se aproxima de Letícia e também retira a tampa da garrafa e coloca os canudos dentro. Amanda olha para Isabela, olha para Letícia e vira o corpo em direção a José. As crianças (Letícia, Isabela, Amanda e José) colocam os canudos na 
garrafa. Amanda bate com a garrafa no chão na tentativa de tirar os canudos de dentro. Letícia arregala os olhos com o barulho e afasta-se, virando em direção oposta à de Amanda.

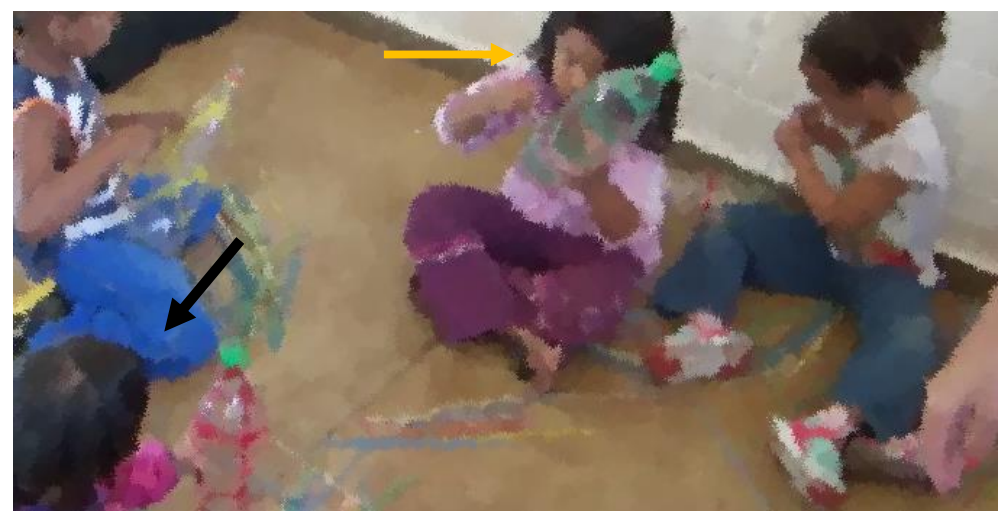

Figura 116. Amanda (flecha preta) olha para a colega Letícia (flecha amarela) enquanto ela coloca o palito dentro da garrafa.

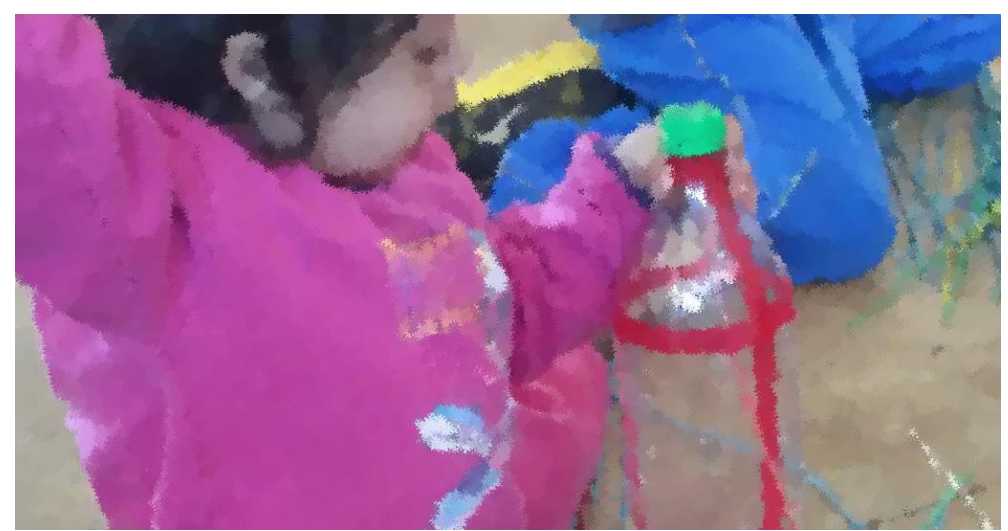

Figura 117. Amanda ergue os braços e fala 'Aharr' depois de conseguir colocar o palito dentro da garrafa.

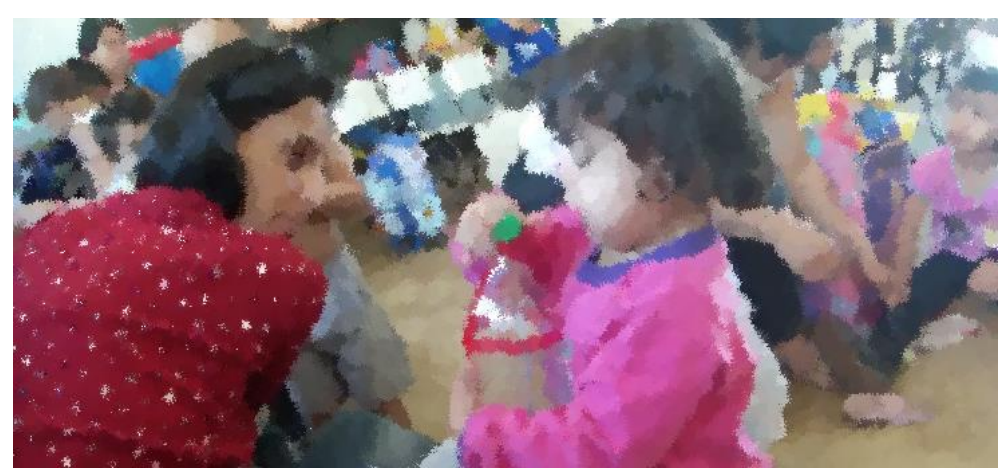

Figura 118. Amanda faz movimento de rotação com os dedos na frente da professora.

Ao se olhar para os episódios de interação no mês de setembro, tendo em vista a identificação de indícios (ou não) para a reflexão sobre a ZPD por meio dos diferentes tipos de aprendizagem e suas possíveis mudanças ao longo do tempo, escolhe-se esse episódio por dois motivos: o primeiro porque ele demarca um novo tipo de aprendizagem, que se refere a uma atividade específica. Em segundo, porque, embora se identifique a corregulação de comportamento, não é especificamente 
por meio dela que essa aprendizagem específica ocorre e sim pelo processo de imitação com modelo anterior. Assim, esse episódio possivelmente amplia o olhar para o fenômeno.

Através dos comportamentos dos pares, Amanda tem ao seu dispor pistas de como realizar a atividade em curso (colocar canudos na garrafa PET). Amanda olha para os colegas, busca neles referências do fazer; dinâmica semelhante é encontrada nos casos Inácio e Ivan, nos episódios "Vocêfaz, eu desfaço, mas assim eu aprendo", do dia 05 de agosto e "Fazendo parte da rotina na escola", do dia 27 de março, respectivamente. À imitação, como já discutido anteriormente, é atribuído um papel importante na socialização e no desenvolvimento da cognição e linguagem, independente da teoria de desenvolvimento que se use para analisá-la (Moura \& Ribas, 2002). Para Vygotsky (2007), a imitação revela as potencialidades no processo de desenvolvimento da criança, uma vez que "as crianças podem imitar uma variedade de ações que vão muito além dos limites de suas próprias capacidades. Numa atividade coletiva, ou sob a orientação de adultos, usando a imitação, as crianças são capazes de fazer muito mais coisas" (p. 101).

Neste sentido, é na imitação que se encontraram as transformações de comportamento para a realização de uma atividade que sozinha a criança pivô não estava conseguindo realizar (colocar os palitos pelo buraco na garrafa PET). A estrutura da corregulação de comportamento (as ações dos pares a partir do comportamento de Amanda) não se diferencia daquelas identificadas em maio e exemplificada no episódio "Explorando meu almoço". Assim como naquela situação, aqui a corregulação acontece no sentido da construção da ação conjunta 'Amanda volta a sentar-se junto aos colegas, olha para Letícia e começa a colocar os canudos de plástico dentro da garrafa. Letícia olha para Amanda e coloca seus canudos dentro da garrafa dela, as duas trocam de garrafa'.

Esse tipo de aprendizagem que se refere a atividades específicas também foi identificado em outro episódio. Nesse, embora ainda se identifique uma imitação simultânea, é a corregulação de comportamento que sustenta o processo de transformação das habilidades da criança pivô.

\section{Amanda em: "Deixa eu te mostrar como é que se faz"}

\section{Data 10 de Setembro de 2014, gravação n.2 aos 21'}

Contexto geral: A turma (29 alunos) está no corredor externo que liga a sala de aula com o pátio. Diferentes brinquedos são espalhados ao longo do corredor e as crianças são colocadas em grupos para brincarem. Amanda é inicialmente colocada em um grupo, mas, ao longo da atividade ela perambula entre as crianças. Ao ouvir os sons de batida produzidos por Gustavo durante a sua atividade com um brinquedo. Amanda escolhe se sentar perto de Gustavo. 
Descrição do episódio: Amanda se abaixa perto e à frente de Gustavo e ao lado de Miguel, que brincam com um brinquedo de encaixe de peças de plástico. Após se sentar. Amanda olha fixamente para Gustavo e o brinquedo. Gustavo está batendo com um pedaço de madeira nas peças de plástico que estão por ele posicionadas nas aberturas de uma base de plástico. Cada peça tem um formato e cor diferente e cada abertura acompanha o formato de uma peça específica. Gustavo bate com um pedaço de madeira nas peças e as faz atravessar a plataforma de plástico. Amanda se aproxima do brinquedo, olha para Gustavo e pega do chão outro pedaço de madeira (amarelo). Amanda bate com esse pedaço de madeira em uma peça próxima de onde Gustavo está batendo, mas não consegue fazer com que a peça atravesse a plataforma. Gustavo para e olha para Amanda, que continua batendo. Miguel também para seu próprio movimento e olha para Amanda enquanto ela bate. Gustavo levanta a mão, sinalizando que Amanda pare e fala: 'deixa eu te mostrar, é assim oh' e bate uma só vez, fazendo com que a peça de plástico passe de um lado a outro da plataforma. Amanda olha para Gustavo e olha para o brinquedo, sorri e toma a peça de madeira das mãos de Gustavo. Amanda bate novamente nas peças e de forma desordenada faz com que as peças se encaixem parcialmente. Gustavo aponta para algumas peças especificas e fala 'aqui oh, termina aqui'. Amanda olha para onde Gustavo aponta. Gustavo continua falando 'uma pecinha, depois essa pecinha, depois a gente vira' (se referindo a virar a plataforma para começar outra vez). Amanda continua batendo e acompanhando a direção apontada pelo colega Gustavo.

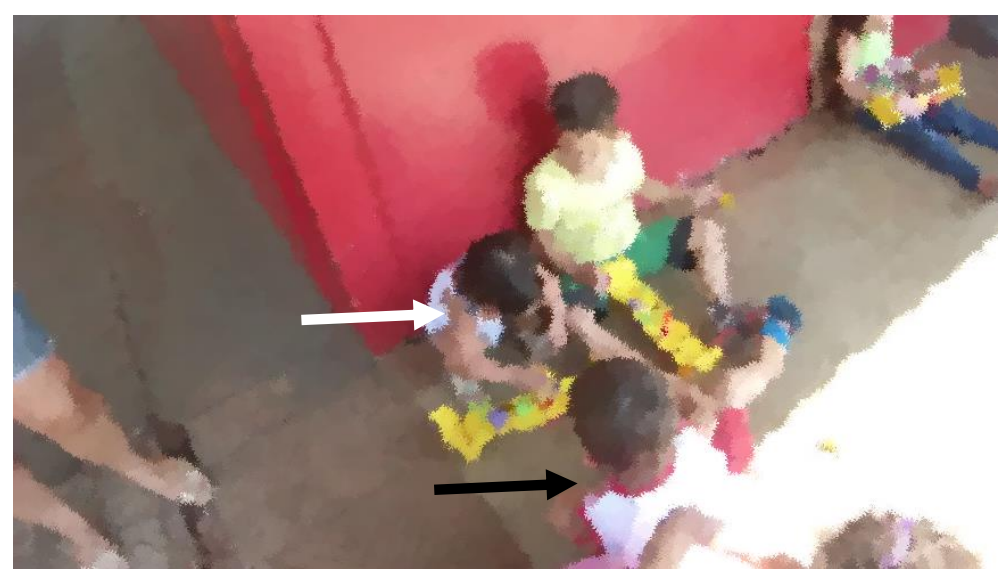

Figura 119. Amanda (flecha branca) bate com o bloco de madeira amarelo na peça vermelha, conforme explicado e feito por Gustavo (flecha preta).

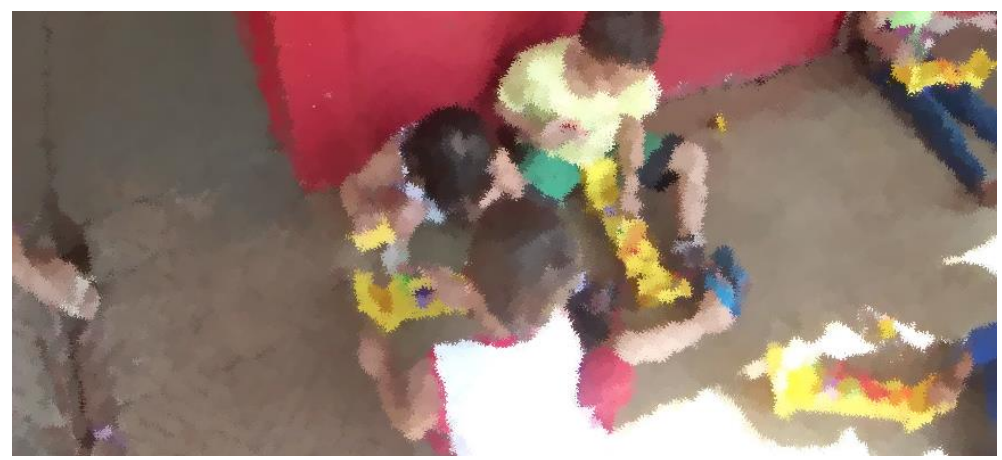

Figura 120. Amanda (flecha branca) bate com o bloco de madeira amarelo na peça vermelha, conforme explicado e feito por Gustavo (flecha preta). 


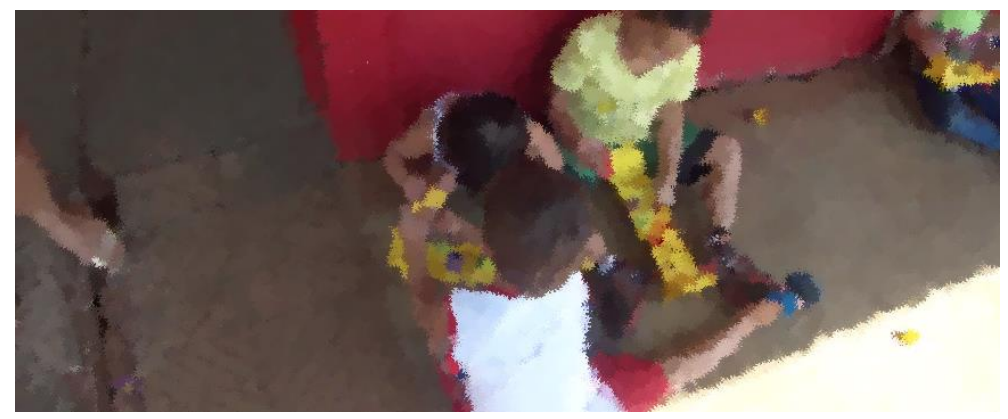

Figura 121. Amanda toma o bloco de madeira amarelo das mãos de Gustavo.

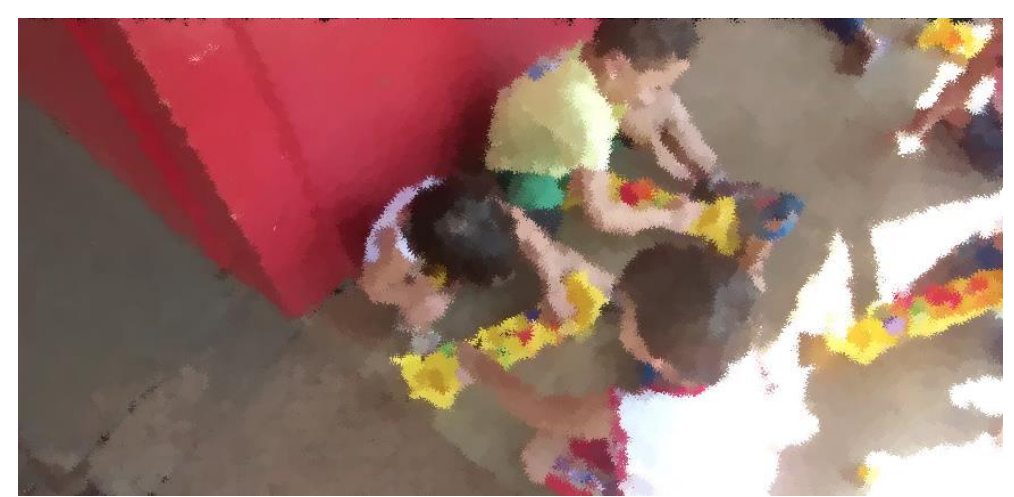

Figura 122. Gustavo aponta para onde Amanda deve bater.

Esse é um episódio de interação bastante significativo, não só no mês de setembro, por marcar um processo de aprendizagem relacionado a uma atividade específica, mas também dentro do conjunto geral de episódios de corregulações de comportamento ao longo do ano. Ele se diferencia dos demais pela instrução verbal sistematizada pela outra criança que possibilita não apenas a construção de uma atividade conjunta, como a transformação dos comportamentos de Amanda no sentido de realizar uma atividade que sozinha ela encontrava dificuldade de realizar.

Esse processo assemelha-se àquele identificado e exemplificado no episódio " $O$ que é isso", do dia 01 de dezembro, no caso Ivan. Da mesma forma, neste episódio, o processo regulatório inicia com estímulos sonoros, quando Amanda ouve as batidas de Gustavo no brinquedo e se aproxima, observando o que está acontecendo. Estímulos sonoros ou visuais não foram particularmente significativos ao longo das análises das regulações de comportamento no caso de Amanda, mas aqui eles demarcam o motivo que faz com que ela caminhe em direção a esse grupo de crianças.

A partir da aproximação de Amanda e do fato dela bater com outro pedaço de madeira no brinquedo, o par abre espaço para a criança pivô utilizar o brinquedo. Mais do que isso, Gustavo orienta com gestos e instruções verbais o que Amanda precisa fazer. Para isso, o par analisa o que pode estar errado nos comportamentos expressos por Amanda tendo como referência seus próprios gestos e corrige a colega nas suas ações, expressando-se claramente 'deixa eu te mostrar, é assim 
$o h$ '. Sua fala focaliza a atenção da criança pivô que 'olha para Gustavo e olha para o brinquedo, sorri e toma a peça de madeira das mãos de Gustavo. Diferente do caso de Ivan em que a intencionalidade é inferida a partir do movimento de espera, da troca de olhares e dos tipos de gestos expressos pelo par, aqui a intenção está na pronta resposta verbal do par e na direta mostra do comportamento desejado.

Neste episódio, é a resposta de Amanda (ajustar seus gestos de acordo com a instrução do par) a partir das ações intencionais de Gustavo (instruir com gestos e fala como usar o brinquedo) e a intenção inicial de Amanda (aproximar-se e tomar parte da brincadeira) que se tornam significativas. Tal dinâmica ilustra o que Reddy (2015) aponta em seus estudos sobre o compartilhamento de intenções na infância, que "ações intencionais compartilhadas são melhor entendidas enquanto processos pelos quais o reconhecimento da intenção é desenvolvido, ao invés de apenas como produto desse reconhecimento" (p. 24). E, neste sentido, a intencionalidade emerge na ação de engajamento para a atividade conjunta, o que muda a estrutura dessa interação, diferenciando-a das demais as corregulações de comportamento ocorridas neste caso até então.

A criação da Zona de Desenvolvimento Proximal na interação de pares é entendida neste episódio por meio do que Holzman (2010) vai chamar de noção de coletividade em que a chave do conceito de ZPD é a ação conjunta de pessoas. Segundo Vygotsky (2007), existe uma variedade de processos internos de desenvolvimento que somente na ação com o outro podem ser operados. Um desses processos seria a compreensão da ação do outro, enquanto uma competência identificada em bebês humanos desde os primeiros meses de vida, quando reagem de formas diferentes diante de tipos específicos de ações de adultos ou na relação com pares (Amorim, 2012; Behne, Carpenter, Call \& Tomasello, 2005; Fawcett \& Liszkowski, 2012; Reddy, 2010; Moura (2009); Tomasello, 1999; Woodward, 2009) e que se desenvolve continuamente até a completude do sistema linguístico e simbólico do ser humano. Neste sentido, a dinâmica apresentada por esse episódio possibilitou a aprendizagem para ambas as crianças, dentro dos seus singulares percursos de desenvolvimento.

Em dezembro, no último mês de coleta de dados, as corregulações envolvendo Amanda acontecem exclusivamente na aula de educação física na quadra, em situações ou de conflito com o par $(n=5)$, ou na construção de uma atividade conjunta $(n=3)$, em um total de oito episódios. Nas situações de conflito, os episódios foram na sua totalidade iniciados por Amanda que, recorrentemente, pega a peteca das mãos do colega (diferente par é envolvido em cada episódio) e a joga do outro lado da mureta que circula a quadra. Os episódios são curtos, rapidamente interrompidos pela professora de educação física ou pelas monitoras que intervêm e retiram Amanda de perto daquela criança específica. Suspeita-se que Amanda estivesse iniciando um tipo 
de brincadeira com os colegas, dado ao seu sorriso na execução da ação e a sua persistência no mesmo gesto. Contudo, as interrupções não permitem a continuidade do processo e por falta de evidência empírica não se pode afirmar que essa hipótese esteja correta.

Nas situações de construção de atividade conjunta identifica-se a iniciativa vinda do par, que chama a atenção de Amanda para o uso dos objetos (raquete e peteca). Em duas das três situações, se identificam os movimentos de imitação com modelo, próprios do repertório de Amanda desde o início do ano. Todavia, em um desses episódios, foi identificado pela primeira vez uma imitação sem modelo, o que possivelmente evidencia desenvolvimento nos processos de representação para Amanda. Este episódio de corregulações de comportamento, diferente dos demais apresentados até então, constitui-se por ações que se sucedem em uma sequência não linear. Isso significa que o comportamento que demarca o episódio de regulação ocorre tempos depois (em meio a outros processos) da manifestação do comportamento do par que regula a criança pivô, mais precisamente cerca de quarenta segundos depois de outros gestos.

\section{Amanda em: "Era para ser badminton, mas acabou sendo basquete"}

\section{Data: de dezembro de 2014, gravação n.1 aos 3'45',}

Contexto geral: As crianças estão na aula de educação física e a atividade orientada pela professora é para que as crianças explorem a utilização de raquetes de pingue-pongue e bolas de badminton. Cada criança recebeu uma raquete e uma bolinha e podia utilizar do espaço da quadra para brincar.

Descrição do episódio: Amanda olha atentamente para André, que está arremessando a peteca de badminton em direção a rede de basquete da quadra. André lança a peteca, que por sua vez. encosta na rede da cesta de basquete. Amanda caminha em direção a ele, mas é interrompida pela professora, que vem ao seu encontro e lhe entrega a raquete que Amanda havia deixado para trás. Amanda pega a raquete e sai correndo pela quadra. Quarenta segundos se passam, sem que (???) outras interações aconteçam. Amanda olha para a cesta de basquete, caminha em direção a ela e se posiciona no mesmo lugar que André estava momentos antes e arremessa a sua peteca de badminton em direção à rede da cesta de basquete. Seu arremesso não consegue atingir a cesta. A peteca cai das mãos de Amanda antes dela conseguir jogar. André que olhava Amanda arremessando se aproxima, olha para Amanda e fala: 'É mais alto,...agora é minha vez', e lança a peteca em direção à cesta. A peteca atinge a rede da cesta e cai. Amanda olha para a peteca, olha para André, sorri. Amanda abaixa e pega a peteca que caiu no chão. Outras crianças se aproximam (Gustavo e Rafaela) e imediatamente começam a arremessar a peteca. Amanda olha para Rafaela, sorri e balança as mãos; depois, olha para André. As crianças riem, pulam e nesse movimento se posicionam na frente de Amanda. Rafaela arremessa, Gustavo, Amanda e André olham e sorriem. Gustavo arremessa sucessivamente para a rede. Amanda olha para as petecas sendo arremessadas, puxa a camisa de Gustavo colocando-se à frente dele e também arremessa. As crianças arremessam as petecas em direção à rede mais algumas vezes nos próximos trinta e sete segundos. 


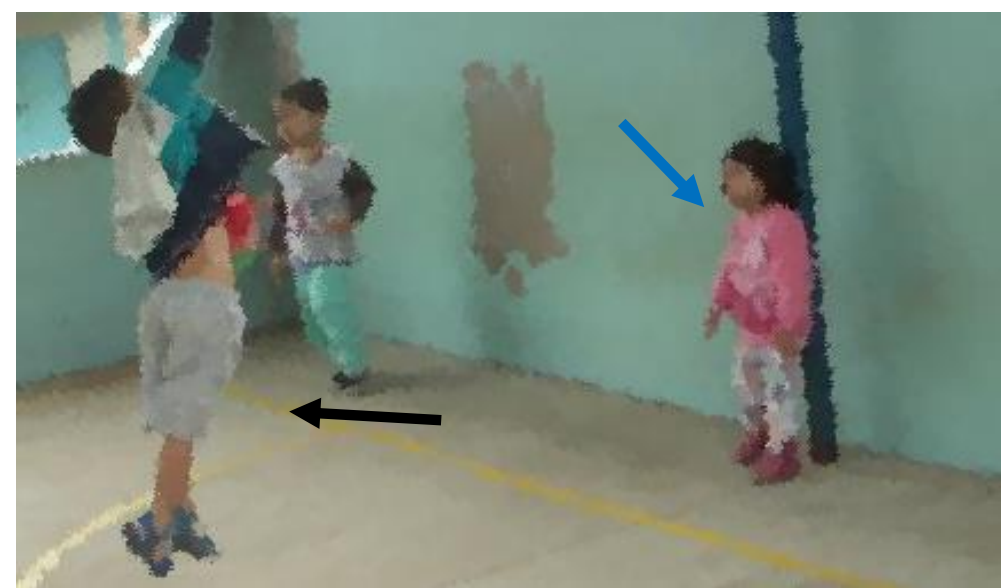

Figura 123. André (flecha preta) arremessa em direção a cesta de basquete e Amanda (flecha azul) observa.

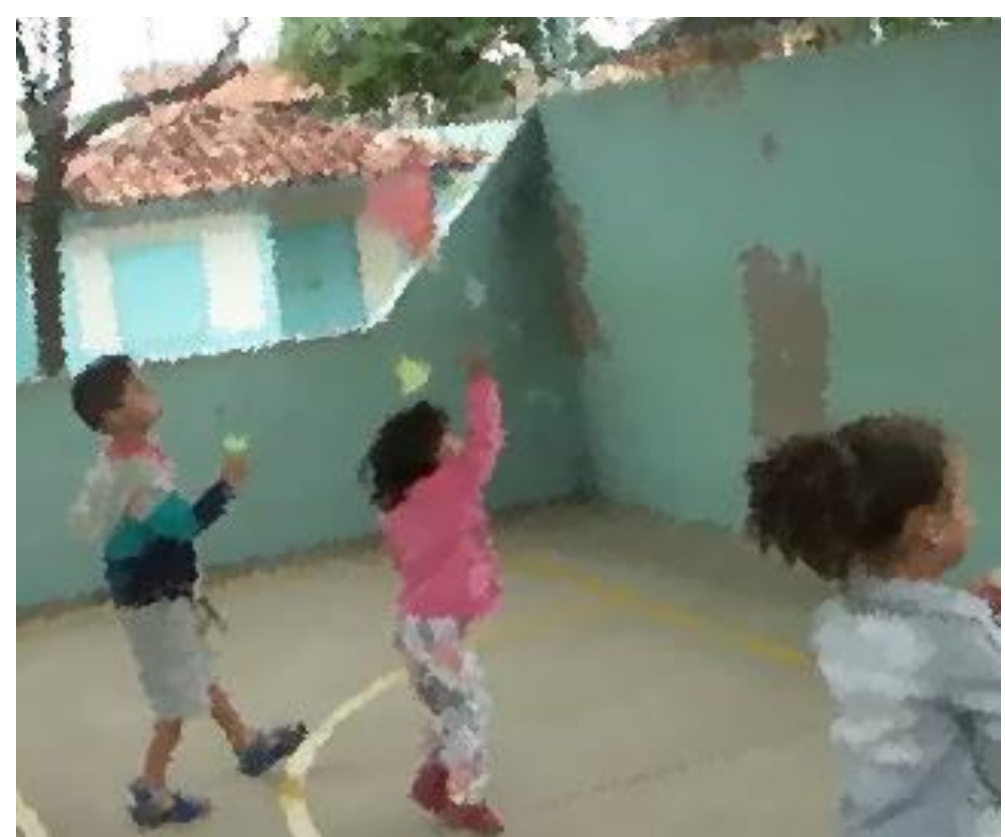

Figura 124. Amanda arremessa para a rede de basquete e André olha se aproxima.

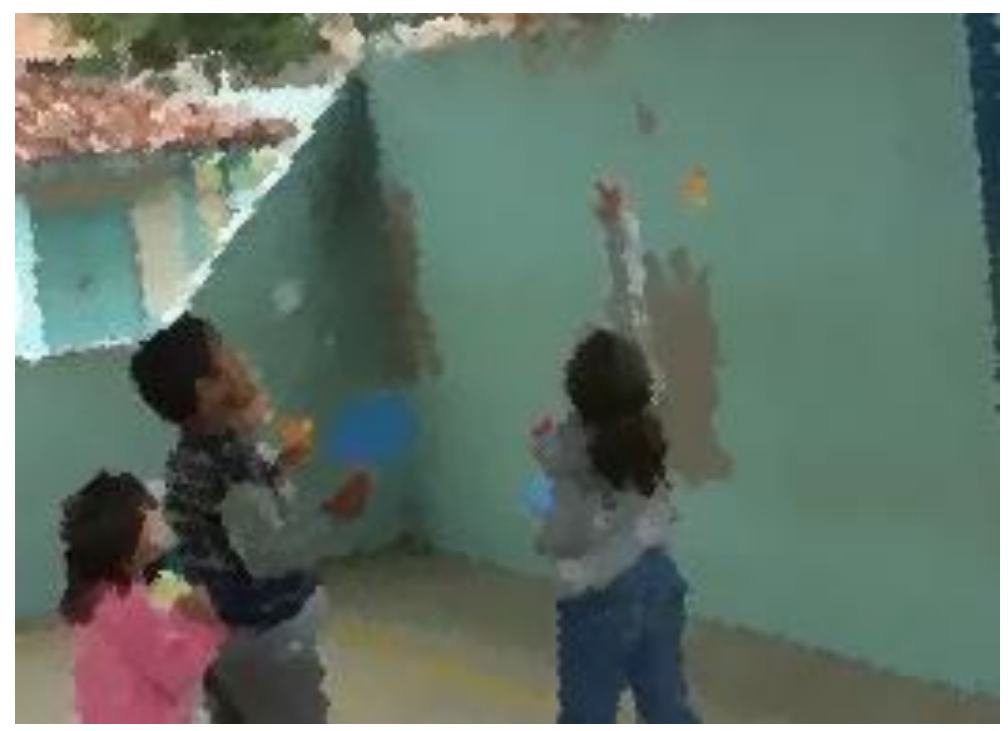

Figura 125. As crianças brincam de arremessar as petecas para a rede. 
No episódio "Era para ser badminton, mas acabou sendo basquete", foi notado pela primeira vez um processo de imitação sem modelo por parte de Amanda, o que se configura como um elemento significativo na análise de como as interações foram sendo construídas ao longo do tempo. Entretanto, antes de apresentar as especificidades desse processo de imitação, julga-se necessário discutir sobre a estrutura das corregulações envolvendo esse episódio e as aprendizagens a partir das ações dos pares.

André, o par de quem Amanda inicialmente imita o comportamento, não foi ao longo do tempo uma criança significativamente presente nas interações envolvendo Amanda. No total, foram cinco episódios conforme tabelas 17 e 18 (páginas 150 e 151), não sendo considerado um par preferencial. Dessa forma, suspeita-se que tenha sido o comportamento da criança (arremessar a peteca para a rede) que tenha chamado a atenção de Amanda. A ação de arremessar a peteca em direção à rede de basquete é entendida, neste contexto, como uma contraproposta de atividade àquela orientada pela professora. As crianças, para atingirem seus propósitos de brincar "selecionam parte do que apreendem, reproduzem interpretativamente por meio de suas ações, mas vão além disso e criam novos procedimentos, regras e informações que alçam de situações particulares" (Pedrosa \& Santos, 2009, p.53).

Ao lembrar que as crianças estão tendo aula de educação física na quadra poliesportiva da escola e que o objeto de principal referência seja a rede de basquete, considera-se que a utilização desse espaço, a partir das referências culturais específicas (por exemplo, jogo de basquete), tenha sido relevante para o surgimento da novidade compartilhada pelo grupo. Essa reprodução interpretativa da cultura (Corsaro, 2009), pode surgir desde o uso diferenciado de objetos específicos (neste caso a peteca de badminton enquanto uma bola para o basquete), a transgressão de uma regra (ao invés de bater na peteca com a raquete, arremessa-se para a rede) e a sincronia de ações (identificada desde o início do engajamento do grupo de criança) (Pedrosa \& Silva, 2009).

É importante entender esse processo porque na situação desse episódio, Amanda é quem vai desempenhar o papel de retomar a ação inicial (arremessar a peteca), sustentando a corregulação de comportamento que vai transformar o gesto individual de André em um processo coletivo, uma atividade que possivelmente se configure em um "conjunto estável ou rotinas, valores e interesses que as crianças produzem e compartilham na interação de pares" - cultura de pares (Corsaro, 2009, p.32). Dessa forma, a corregulação de comportamento (ação subsequente de André ao aproximar-se de Amanda após ela ter arremessado a peteca) pode não estar diretamente relacionada a identificação pelo par da necessidade de Amanda por auxílio para a realização da 
atividade como no episódio "Deixa eu te mostrar como é que se faz" do dia 10 de setembro. Embora haja a instrução verbal 'é mais alto' apontando como realizar o movimento, o engajamento na atividade acontece pelos movimentos em si, pela troca de olhares e sorrisos e, principalmente pelo ritmo estabelecido entre as crianças ao longo da atividade.

Assim, infere-se que a corregulação de comportamento esteja relacionada ao comportamento do arremesso em si, que retoma a intenção inicial (anterior) de André por uma atividade diferente da proposta pela professora. A diferença na estrutura da corregulação entre o episódio "Deixa eu te mostrar como é que se faz" e o episódio "Era para ser badminton, mas acabou sendo basquete" muda a posiçãolpapel de Amanda na dinâmica da interação, tornando-a agora a proponente da construção da brincadeira, ao invés de alguém que aprende como se usa o brinquedo. A aprendizagem, neste sentido, está relacionada aos processos sociais de compartilhamento de significado para o fazer conjunto e a possibilidade de fazer parte dessa construção como proponente da mesma.

A imitação sem modelo, ou imitação 'real ou diferida' (Wallon, 2008) se dá quando a “criança começa a descobrir sua própria vigilância motoralpostura, presente em seus gestos e movimentos" (Vasconcellos, 1996, p. 39). Neste processo, a identificação com o par que antes a levava a uma união mimética, possibilita agora relações de simpatia e a eleição de parceiros constantes, mas a elaboração da diferenciação Eu\outro permite que a criança compreenda seu próprio papel na interação social, um importante elemento para o avanço na representação. Essa é a primeira vez que esse processo é identificado nas interações de pares desse caso, o que possivelmente indica que Amanda esteja vivenciando transições entre fases, próprias do processo de desenvolvimento proposto por Wallon (Oliveira, 2011; Vasconcellos, 1996; Vasconcellos \& Valsiner, 1995). A interação de pares por essa perspectiva, estabelece o contexto para que a complexidade de elementos envolvidos seja vivenciada, permitindo a transposição das crises próprias desse estágio.

Em conclusão, ao se analisar como se configuraram as corregulações de comportamento com atenção conjunta elou compartilhamento de objeto neste estudo de caso específico ao longo do tempo, identifica-se que, desde o início, existiu uma disposição e iniciativa por parte do par no fazer conjunto com Amanda, apesar da constante presença e mediação do adulto nos processos interativos, muitas vezes interrompendo ou modificando a natureza da negociação dos pares. Os tipos de aprendizagem estão, majoritariamente, relacionados a esse fazer conjunto, à construção de atividades coletivas. Contudo, identifica-se um crescente na complexidade das atividades e na estrutura dos comportamentos de corregulações de comportamento: de uma brincadeira que consiste na cópia dos comportamentos do par durante a transformação de regras sociais em ritual 
particular (gesto de comer com as mãos), para a brincadeira que envolve a habilidade de encaixar blocos e, posteriormente, a brincadeira que se constitui na participação do processo de transformar a utilização de um objeto em outro (peteca em bola - badminton em basquete) e a certa adequação nos movimentos para a utilização desse objeto (arremesso mais alto da peteca em direção a rede).

Por fim, da mesma forma que nos casos anteriores, entende-se que em todas as três fases de coleta de dados foram encontradas evidências empíricas que permitiram a discussão da existência de ZPDs, cabendo destacar que, ao longo dessa terceira fase, buscou-se explorar a ZPD pela perspectiva coletiva (Holzman, 2010) em que há uma ênfase na sociabilidade do processo de aprendizagem que conduz ao desenvolvimento e, portanto, a ZPD está naquilo que as pessoas estão fazendo juntas.

\subsubsection{Reflexões sobre os resultados na fase III}

O foco das análises na fase III, recaíram sobre as transformações na forma como as interações de pares se constituíram ao longo do ano, privilegiando a identificação de processos de aprendizagem através das corregulações de comportamento e indícios que permitissem a reflexão sobre a ZPD na relação de pares. Dentre os resultados apresentados, destacam-se aqui quatro elementos: (1) foram identificadas, em todos os três casos, transformações na forma como as interações são constituídas_ao longo do tempo, apresentando um gradativo aumento na sua complexidade; (2) as aprendizagens construídas nas corregulações de comportamento foram diversificadas, ora tangenciando aspectos sociais do processo de escolarização, ora se referindo a uma atividade específica; (3) a imitação novamente aparece como elemento central e estruturador dos processos regulatórios; e, (4) o interesselenvolvimento dos pares_no fazer conjunto com a criança pivô e o percurso histórico dessas interações no cotidiano escolar desempenharam um papel importante na criação das Zonas de Desenvolvimento Proximais e de desenvolvimento dos participantes pivôs.

As transformações na forma como as interações foram constituídas ao longo do tempo dizem respeito à estrutura dos processos de corregulações, ou seja, a forma como a reciprocidade acontece entre as ações da criança pivô e as de seus pares (e.g., com proximidade física, gestos, fala, troca de olhares, compartilhamento de objetos, dentre outros). A corregulação de comportamento é discutida enquanto um processo de ajustamento entre os membros do campo social, pelo qual se alcança o compartilhamento de significado (Carvalho et al. 1996). Esse processo pode, ou não, desencadear a correlação, "que implica síntese ou condensação de informação, expressando o que é comum ou compartilhado e eliminando informações irrelevantes" 
(Carvalho \& Rubiano, 2004, p. 173) para o compartilhamento de significado. É na correlação que se identifica a persistência de significado, princípio constitutivo do fenômeno da cultura (Carvalho \& Rubiano, 2004).

Pela análise conduzida nesta fase III, observou-se que, aos processos de corregulações de comportamento foi incorporado um número cada vez maior de elementos (e.g., olhar, contato físico, gestos, movimento, fala) com o passar do tempo. Essa incorporação de novos e diferentes subsídios na interação, ao mesmo passo que viabilizou novas perspectivas para as situações de aprendizagem, também estruturou processos mais complexos de compartilhamentos de significado que, por exemplo, iniciaram com situações de imitação simultânea e desenvolveram a uma imitação diferida (caso Amanda); ou ainda, iniciaram com processos ainda dentro de um conflito de identificaçãoldiferenciação Eu\outro e desenvolveram a uma situação de diálogo por meio da protoconversação (caso Inácio).

Em estudos empíricos sobre cultura de pares em grupos de brinquedo (Lucena, 2010; Pedrosa \& Santos, 2004), fora observado que o compartilhamento de significados amplia a possibilidade de complexificação da sequência interacional que as crianças desenvolvem. E, por diferentes perspectivas essa complexificação tem sido discutida como evidência da capacidade ou propriedade interpretativa que as crianças exercem no brincar, fazendo emergir novos significados e revelando sua autoria no processo de apropriação do mundo (Corsaro, 2003; 2005; 2009). Contudo, diferente dos achados no trabalho de Lucena (2010) que focalizam no desenrolar de atividades de brincar similares em momentos distintos; e, ainda, com um enfoque diferente ao dado por Corsaro (2009) que discute esse processo pela perspectiva da reprodução interpretativa da cultura, o que está se sugerindo aqui é que existe um aumento sucessivo na complexidade nas relações de pares em si, nas suas diferentes situações ao longo do tempo. Embora o brincar seja o principal meio pelo qual as crianças constroem cultura de pares, a complexidade não se restringe aos aspectos constitutivos da atividade em si (da brincadeira), mas às demandas do estarlconhecer o outro, compartilhar com o ele e constituir-se na experiência institucional como um todo.

Retomando o estudo de caso Ivan como exemplo, as corregulações iniciam sem nenhum contato físico direto entre as crianças, sem instruções verbais para a realização da atividade ou ainda sem nenhum comportamento que indicasse intencionalidade para o fazer conjunto. A corregulação apenas oferece suporte para a atividade em curso. Mas, com o passar do tempo, observa-se que na interação com os pares outros elementos vão sendo incorporados (contato físico, a fala, os gestos direcionados ao par) permitindoldemandando novos compartilhamentos de significado. A incorporação de novos elementos é gradativa e cumulativa, indicando que entre as 
diversas interações ao longo do tempo são mantidos significados previamente compartilhados. Ao final do ano, as corregulações são compostas por diferentes elementos (instrução verbal, contato físico, troca de olhar), com comportamentos que explicitam intencionalidade e permitem a construção conjunta da atividade (brincadeira). Dessa forma, quando se aponta que ao longo do tempo (e.g., de março a dezembro) identificaram-se transformações na forma como as corregulações aconteceram, significa que, dentro da temporalidade do processo de coleta de dados, os diferentes elementos que foram incorporados na interação impactaram na maneira como os pares compartilharam significados e construíram a experiência conjunta. É nesse gradativo aumento de complexidade (tanto de elementos da corregulação, quanto nos processos de atividade conjunta) que se entende identificar a evidência mais relevante para a discussão do desenvolvimento ao longo do tempo pela açãolinteração dos pares, nos contextos institucionais analisados.

Segundo Vygotsky (1995), o indício de desenvolvimento está justamente nos processos cumulativos que gradualmente diferenciam os comportamentos do sujeito, destacando nesse processo os signos como instrumentos de caráter cultural que têm o papel mediador essencial para o desenvolvimento das funções psíquicas. A cultura é, portanto, o processo pelo qual "o homem social modifica os modos e procedimentos de sua conduta, transforma suas inclinações naturais e funções, elabora e cria novas formas de comportamento especificamente cultural" (Vygostky, 1995, p. 34). Isto posto, embora neste momento da sua obra, Vygotsky não estivesse falando das possibilidades desse desenvolvimento na situação de interação de pares, entende-se que seja necessário trazer a discussão sobre como a construção da cultura na infância, evidenciada ao longo dos episódios apresentados, poderia ser entendida à luz do que Vygotsky identifica enquanto indícios de desenvolvimento. "A cultura origina novas formas de conduta, modifica a atividade das funções psíquicas, edifica novos níveis no sistema do comportamento humano de desenvolvimento" (Vygotsky, 1995, p. 34). A construção de cultura de pares, neste mesmo sentido e dentro do contexto e percurso de desenvolvimento de cada uma das crianças pivô, possibilitou a esses sujeitos construir novas forma de conduta (e.g., do participar através da imitação simultânea ao participar na ação coletiva no caso de Ivan), modificar as funções psíquicas (e.g., da imitação mimética à imitação diferida no caso Amanda) e edificar novos níveis no sistema de comportamento humano (e.g., desenvolvimentos gradativo dos processos comunicativos com seus pares, no caso de Inácio).

O segundo ponto considerado relevante nos resultados da fase III de análise diz respeito às aprendizagens constituídas nos processos de corregulações de comportamento. Para continuar essa reflexão, julga-se importante retomar dois aspectos fundamentais do que é desenvolvimento 
para Vygotsky: primeiro, embora Vygotsky tenha dado enfoques diferentes ao tema ao longo da trajetória de seu trabalho, o desenvolvimento humano para esse autor é integral e caminha para o rompimento da barreira entre o social e o individual, o cognitivo e o emocional (Gonzalez-Rey, 2011); e, o segundo, é que o desenvolvimento para Vygotsky mantém uma relação unitária e de completude com a aprendizagem (Newman \& Holzman, 2002). Dessa forma, nessa fase III de análise, buscou-se olhar para os episódios de interação neste contexto institucional a partir dessas considerações teóricas e quando se reflete sobre as aprendizagens construídas nas corregulações de comportamento, entende-se que a diversidade que ora tangencia aspectos sociais do processo de escolarização (por diferentes ângulos) e ora se refere a uma atividade específica (circunscrita na rotina específica de cada criança), está diretamente relacionada com as demandas das interações de pares em si, com o contexto em que essas interações estão circunscritas (a instituição de educação infantil), mas sobretudo com o fato de que o desenvolvimento humano é por si só um processo complexo, multideterminado e dependente da variabilidade dos significados que emergem das articulação de elementos dentro das interações entre os sujeitos (Rossetti-Ferreira, Amorim \& Silva, 2004).

Os resultados da fase III de análise indicam que as crianças pivô na interação de pares (e vice-versa) estão em constantes processos de aprendizagem. Tais processos, na mesma medida que abrangem aspectos considerados individuais da diferenciação Eu\outro imprescindíveis para o desenvolvimento da representação e, posteriormente, o pensamento abstrato, perpassam pelas aprendizagens relacionadas a atividades específicas da rotina institucional (e.g., desenhar, montar blocos, manipular massa de modelar para representar objetos, desenvolver coordenação motora fina e etc.), e tangenciam aprendizagens de elementos que são imprescindíveis para a vida em sociedade, a comunicação. Esse conjunto de diferentes elementos apreendidos são os meios pelos quais essas crianças foram constituídas ao longo desse período. Os processos de aprendizagem não são estanques, fragmentados para a identificação do desenvolvimento de uma específica habilidade, as aprendizagens envolvem a multiplicidade e a complexidade que é própria do ser humano.

Novamente a imitação configurou-se como um elemento central nos processos interativos de todos os estudos de caso deste trabalho. Segundo Newman e Holzman (2002), para Vygotsky a imitação é de fato o processo "que torna possível o desenvolvimento das capacidades da criança em virtude de fazer o que ainda não consegue fazer" (p. 170), cabendo aqui destacar que esse 'fazer' não está necessariamente associado a uma atividade específica da rotina institucional, mas se estende aos processos todos que envolvem a constituição do sujeito. Dessa forma, a imitação só ocorre na ZPD e se configura na atividade revolucionária de criar significados. 
O quarto aspecto relevante dessa fase de análise diz respeito ao interesselenvolvimento dos pares no fazer conjunto com a criança pivô. Interpreta-se o aumento do interesse dos pares e, de forma geral, o maior envolvimento desses nas interações (manifestação de comportamentos com propósito deliberado) como sendo implicação da, também gradativa, possibilidade de compartilhar significados diferentes no percurso histórico dessas interações, que vão ampliando os repertórios de comunicação entre as crianças, através da persistência desses significados. Contudo, ao mesmo tempo em que o aumento do interesse dos pares é resultado dos compartilhamentos de significados, entende-se que tal envolvimento, expressado principalmente por meio de comportamentos com propósito deliberado para a ação com a criança pivô mediados pela linguagem verbal, também tem um papel importante na criação das Zonas de Desenvolvimento Proximais. Foram nesses momentos (e.g., episódios: "Deixa eu te explicar" Inácio; "Pode deixar que a gente se entende" - Ivan; "Deixa eu te mostrar como é que se faz" Amanda;) que, primeiramente, a compreensão da linguagem verbal enquanto elemento central para o desenvolvimento das funções mentais superiores (Vygotsky, 2007), mesmo que acompanhada de outros processos, é demandada e faz parte do que a criança vai se apropriar no exterior para orientar suas próprias ações. Segundo, são nesses momentos que a interação abre espaço para que o fazer da criança pivô direcione o fazer de seus pares, permitindo reconhecimento da autoria dessa criança com deficiência na construção conjunta de determinada atividade. 


\section{Discussão final}

O presente trabalho teve início a partir da hipótese de que processos de interação de pares de idade, manifestados pelas regulações e corregulações de comportamento, representam um dos elementos circunscritores de desenvolvimento de crianças, inclusive de crianças com déficit intelectual, em contexto de inclusão em instituição escolar. Para dar sustentação à hipótese, fundamentalmente a partir do referencial teórico histórico-cultural de Lev S. Vygotsky e considerando a perspectiva de desenvolvimento humano da Rede de Significações (RossettiFerreira, Amorim, Silva \& Carvalho, 2004), discutiu-se que, por meio dessas interações de pares, há a possibilidade de transformação de habilidades potenciais em reais, desdobrando o conceito teórico da Zona de Desenvolvimento Proximal.

Dentro dessa perspectiva, buscou-se apreender os processos interativos de crianças com e sem déficit intelectual no contexto da educação infantil, analisando como as regulações e corregulações de comportamento acontecem e se haveriam indícios empíricos que sustentariam a discussão conceitual de Zonas de Desenvolvimento Proximal na interação de pares de idade. Para tanto, diferentes aspectos sobre os processos de regulação e corregulações de comportamento foram analisados em três distintas fases de análise de dados.

Neste momento, a partir das reflexões das três fases de análise dos dados, discute-se que a verificação de que as interações de pares possibilitamlpromovemldelimitam processos de desenvolvimento que podem ser entendidos dentro da perspectiva conceitual da Zona de Desenvolvimento Proximal. Para tanto, resgatam-se as questões instigadoras da realização desse estudo, colocadas na introdução do trabalho.

Como acontecem os processos de interação de pares quando da presença de uma criança com déficit intelectual?

A partir do referencial adotado neste estudo de que a interação se caracteriza por "um potencial de regulações entre componentes do campo social" (Carvalho, Império-Hamburger \& Pedrosa, 1996) aponta-se que as interações de pares, quando da presença de uma criança com déficit intelectual ocorrem: (1) em todos os espaços do contexto institucional, constituindo diferentes e variadas situações; (2) acontecem circunscritos e delimitados pelas ações mediadas do adulto, seja ele o professor ou educadoreslmonitores de turma; e, (3) ocorrem em situações com atenção conjunta e compartilhamento de objetos, mas também na ausência desses elementos. Ainda, os resultados ainda apontaram a reciprocidade na procura pela interação, evidenciando que as crianças pivô não são as únicas a buscarem pelo contato dos pares, mas os pares também buscam 
o contato com as crianças pivô e são por elas regulados. Contudo, o elemento que se destaca a partir dos resultados para a discussão proposta neste estudo é que as interações acontecem, preponderantemente, por meio de processos de imitação. Dessa forma, para se entender o papel das interações de pares no processo de desenvolvimento da criança pivô e, possivelmente, identificar transformações ao longo do tempo, precisou-se olhar para as diferentes perspectivas teóricas que explicam o processo imitativo.

Ao longo desse processo, aproximações com o referencial teórico de Wallon (1975; 1986; 1995; 2008) foram de extrema relevância, principalmente no que se refere ao entendimento das transformações do processo imitativo - partindo do mimetismo para a imitação diferida, e o seu impacto para o desenvolvimento humano. Os resultados, particularmente os apresentados na fase II e III de análise, revelam que a imitação foi o principal processo pelo qual as regulações (com ou sem atenção conjunta e compartilhamento de objeto) e corregulações de comportamento foram evidenciadas e também pelo qual novas aprendizagens ocorreram.

A imitação é reconhecida como um elemento importante no processo de aprendizagem ao longo da infância em trabalhos prévios (Costa, 2000; Galvão, 2001; Moura \& Ribas, 2002; Newman \& Holzman, 2002; Oliveira, 2011; Valsiner \& Van Der ver, 1993), conforme apontado nas reflexões da fase II e III. Contudo, a forma como se interpretaram os resultados dentro da discussão da Zona de Desenvolvimento Proximal demandou que se retomasse mais uma vez ao que Vygotsky entende sobre a relação entre desenvolvimento e aprendizagem, que é, por sua vez, rica, complexa e única. Trata-se de uma relação de unidade, em que a aprendizagem conduz o desenvolvimento a partir de uma perspectiva de "bi-condição" histórica do outro (Newman \& Holzman, 2002). Isso significa que não são processos separados, ou tampouco idênticos, nem podem ser estabelecidas entre eles relações de causa e efeito. A relação unitária de que 'aprendizagem-conduz-desenvolvimento' é uma relação de complementaridade, em que “a aprendizagem 'completa' o desenvolvimento, enquanto o desenvolvimento completa a aprendizagem" (Newman e Holzman, 2002, p. 167). Dessa forma, se a característica sociológica central da teoria de Vygotsky é a sua compreensão de que aprendizagem-conduz-desenvolvimento, como afirma Newman e Holzman (2002), a imitação enquanto uma situação que "torna possível o desenvolvimento das capacidades da criança em virtude de fazer o que ela ainda não consegue fazer" (p. 170), seria evidência comportamental de que, na interação com os pares, criam-se condições de aprendizagem ldesenvolvimento, sendo portanto possível interpretar tais situações dentro da perspectiva teórico-conceitual da Zona de Desenvolvimento Proximal. 
Que elementos da corporeidade participam da construção dessa interação?

A corporeidade e a sua participação na construção dos processos de interação foram evidenciadas principalmente pelos contatos físicos que, enquanto elementos que também demarcam a interação, aconteceram ao longo de todo o período de vídeo registro, conforme apontado principalmente ao longo da fase I de análise.

Esse contato físico aparece delineado e delimitado por diferentes elementos provenientes da estrutura do espaço físico (tipo, divisão e utilização do espaço), da dinâmica institucional (rotina diária e tipos de atividade) e da prática pedagógica adotada em cada Instituição e por cada professora. Tal resultado corrobora com diferentes estudos que já apontavam para a relevância da análise do espaço escolar para o entendimento da experiência vivencial da criança na instituição (Kishimoto, 2000; Raittiala, 2012; Rutanen, 2014; Schmitz, 2012; Vuorisalo, Rutanen \& Raittila, 2015). Contudo, de forma bastante singular entre os três estudos de caso, os resultados sobre os contatos físicos revelaram a intensidade das situações de interação e a iniciativa dos processos de busca pelo outro em relação a esses diferentes espaços, assim como, o conteúdo do processo regulatório (em que situação o contato físico é utilizado), mostrando ser um elemento imprescindível na análise dos processos interativos de crianças com déficit intelectual em contexto regular de Educação Infantil.

Ainda, o contato físico não garantiulsustentou, solitariamente, as corregulações de comportamento que possibilitaram as transformações de habilidades potenciais em reais. Contudo o contato corporal participa na construção dos processos de comunicação dos pares, possibilitando às crianças pivô integrarem-nos aos seus repertórios de corporeidade (Amorim \& RossettiFerreira, 2008), contribuindo/participando/(re)significando tais corregulações de comportamento. A partir do entendimento de que toda ação do corpo carrega sentido (Furlan, 2004), o contato desempenhou assim um importante papel nas situações de construção de cultura de pares (Corsaro, 2005; 2009), viabilizando a expressão de ideias e a construçãolcompartilhamento de significado.

\section{Seria o par de idade também um colaborador no processo de desenvolvimento?}

A partir das reflexões das três fases de análise, entende-se que sim, os pares de idade contribuem com situações de aprendizagemldesenvolvimento. Na interação de pares, mesmo em situações sem a atenção conjunta ou o compartilhamento de objetos, por meio das regulações de comportamento, as crianças pivô mostraram-se conduzidas ou impelidas a realizarem ações que, sozinhas, talvez não fizessem, conforme discutido na fase II. Nas situações de regulação com atenção conjunta e compartilhamento de objetos foram abertos espaços para processos de imitação e construção de significado, evidenciados principalmente em situações de atividade de 
brincadeira, faz de conta e atividades orientadas (dentro e fora da sala de aula). Por meio de tais processos, os resultados mostraram inúmeras e diferentes situações de aprendizagem, que foram discutidas à luz do conceito teórico da Zonas de Desenvolvimento Proximal e entendidas na sua complexidade enquanto situações desenvolvimentais.

Contudo, os resultados apontaram que foi particularmente nas situações de corregulações de comportamento, que se identificou a intencionalidade por parte dos pares na realização da atividade conjunta com a criança pivô. À intencionalidade usualmente é atribuído um sentido relacionado à motivação intrínseca e à consciência do processo de aprendizagem (Tébar, 2011), dois elementos que são correlacionados à mediação do adulto junto à criança. Todavia, neste trabalho, esse conceito foi discutido a partir das contribuições de Trevarten e Aitken (2001) que defendem que, desde tenra idade, o bebê é equipado com diferentes mecanismos que permitem o funcionamento de uma formação motora que age na coordenação sensório-motora intermodal, permitindo a orientação do recém-nascido a aprendizagem por estímulos preferencialmente humanos. Tal intencionalidade estaria, portanto, diretamente relacionada a essa capacidade do bebê em entender a ação do outro, fenômeno que vêm sendo abordado por diferentes estudos a partir da análise das diversas formas de reação diante de tipos específicos de ações de adultos ou na relação com pares (Amorim, 2012; Behne, Carpenter, Call \& Tomasello, 2005; Reddy, 2010; Seidl Moura, 2009; Tomasello, 1999; Woodward, 2009). Neste sentido, a identificação de comportamentos que possibilitam a discussão de intencionalidade em pares de idade na interação junto a crianças com deficiência intelectual foi considerada um elemento inédito na literatura.

Ao longo do trabalho, a intencionalidade foi identificada e discutida a partir de conjuntos de ações dos pares junto às crianças pivô (e.g., explicar o que está acontecendo para a criança pivô, mostrar o movimento para a realização de atividades específicas e etc.), que possibilitaram a realização por parte das crianças com deficiência de ações em curso, conforme discutido na fase II e III. Assim, considerou-se intencionalidade ações dos pares que ofereceram suporte para que a criança pivô executasse por completo uma determinada atividade, gesto ou movimento, sem se ater na possibilidade ou não de uma consciência do processo de aprendizagem. A intencionalidade foi identificada em todos os três estudos de caso e abriu espaço também para a discussão sobre a construção de intenções compartilhadas (Reddy, 2015). Este é um conceito teórico que entende que é na resposta da criança pivô (corregulações de comportamento), a partir das ações intencionais dos pares, que as intenções desses se tornam significativas; ou seja, que a intencionalidade é construída e constituída pela interação.

Os pares preferenciais se mostraram particularmente importantes para esse processo pois, assim como em estudos anteriores (Lucena, 2010; Pedrosa \& Carvalho, 1995; Pedrosa \& 
Eckerman, 2000), neste também foi identificada a abreviação de significados nos processos comunicativos (Carvalho et al., 1996) e o envolvimento diferenciado no processo interativo, demarcado pela maior procura do par pela interação junto a criança pivô e pela identificação de indícios dessa intencionalidade do par na ação com as crianças pivô. A abreviação de significado e o envolvimento foram elementos que se destacaram no apoio para a imitação e o seguimento de instruções verbais. Contudo, cabe ainda destacar que, mesmo nos episódios de interação em que não se identificam indícios de intencionalidade, as corregulações de comportamento permitiram reflexões sobre como as ações dos pares viabilizam aprendizagens às crianças com déficit intelectual, e também vice-versa. Apesar da intencionalidade ter sido um fator presente, ela não foi decisiva para a identificação de situações de aprendizagemldesenvolvimento.

Por fim, segundo Holzman (2010), a natureza problemática do conceito teórico da Zona de Desenvolvimento Proximal pode ser explicada pelo fato de que Vygotsky usou esse conceito em três diferentes contextos e em momentos de sua obra. A partir das análises Kozulin (2003), entende-se que, no contexto das discussões sobre desenvolvimento, a ZDP é usada para explicar as funções psicológicas emergentes da criança. Já no contexto da aplicação didática, a ZDP explica a diferença entre os desempenhos individual e assistido da criança, tanto em situações de avaliação como na aprendizagem em sala de aula. Finalmente, no âmbito das análises teórica, a ZDP é usada como um "espaço" metafórico em que conceitos cotidianos da criança atendem a conceitos "científicos" fornecidos por professores ou outros mediadores de aprendizagem.

Contudo, neste trabalho, buscou-se transpor todas essas três instâncias (perspectivas) do conceito de ZPD para as análises das situações de aprendizagemldesenvolvimento na interação de pares. Em cada etapa do processo de análise e a partir das diferentes vivências dos três sujeitos que compõem os estudos de caso deste trabalho, foi possível abordar e discutir aspectos distintos do conceito de ZDP na relação de pares estabelecida. A diversidade, as contradições, ambiguidades e os múltiplos fatores que constituíram cada caso, revelam aspectos \perspectivas distintas sobre os processos de desenvolvimento humano na relação com o outro em contexto institucional; elementos que apenas pela perspectiva da complexidade podem ser trabalhados.

Neste sentido, as hipóteses levantadas no início do trabalho de que nas interações de pares existe a possibilidade da criação de Zonas de Desenvolvimento Proximal são confirmadas e defendidas. E, as regulações e corregulações de comportamento se mostraram elementos relevantes e adequados para se observar os processos de aprendizagemldesenvolvimento oriundos das interações de pares em contexto institucional de educação infantil. 
A compreensão sobre como ocorrem as interações de pares pode auxiliar na discussão da inclusão escolar?

Neste ano, completam-se 21 anos desde que a Declaração de Salamanca (Unesco, 1994) foi incorporada enquanto base fundamental para a política de Inclusão Escolar no Brasil. Ao longo dessas duas décadas, diversos foram os trabalhos que discutiram criticamente o que representam e como se interpretam para a prática, as políticas de Inclusão Escolar (Mantoan, 2006; Mazzotta, 2001; Mendes, 2010; Prieto, Pagnez \& Gonzalez, 2014; Souza \& Prieto, 2016), além de diferentes estratégias para se implementar transformações sociais que resultassem na/da Inclusão (Mantoan, 1998; Marques, 2001).

Contudo, na atualidade, o enfoque dos estudos dentro da temática da Inclusão Escolar na Educação Infantil tem recaído sobre a análise da prática direta do professor junto à criança com necessidades especiais e sobre modelos de intervenção precoce para identificar uma educação eficaz e de alta qualidade para crianças com deficiência (ver Boyd, Odom, Humphreys, \& Sam, 2010). Esta abordagem adota, frequentemente, os resultados de aprendizagem das crianças como indicadores de qualidade (Dunst \& Trivette, 2009), mostrando a eficácia da educação pré-escolar nas competências sociais das crianças e no progresso escolar (Camilli, Vargas, Ryan \& Barnett, 2010) ou correlacionando a frequência pré-escolar com desenvolvimento e prontidão escolar (Pianta, Barnett, Burchinal, \& Thornburg, 2009; Strain \& Bovey, 2011).

Naturalmente, ao abordar as capacidades individuais ou programas de intervenção específicos, é possível trazer contribuições significativas para o campo de pesquisa. No entanto, entende-se que é preciso que as pesquisas também abordem os aspectos da participação das crianças nas atividades de aprendizagem conjunta, incentivando a interação entre pares e adotando conceitos mais complexos sobre o desenvolvimento humano dentro do contexto escolar. Dessa forma, entender sobre como as interações de pares e as potencialidades para o desenvolvimento humano contidas neste processo ocorrem, nunca foi tão importante quanto no momento atual, preservando o papel do educador enquanto mediador do processo.

Dentro dessa perspectiva e para responder de forma mais direta à pergunta levantada: sim, a compreensão sobre como ocorre a interação de pares pode auxiliar na discussão da inclusão. Primeiramente, porque se evidenciam os elementos sobre os quais essa interação ocorre (e.g., contato físico, gestos, comportamentos imitativos e etc.), possibilitando que professores e outros profissionais do contexto institucional possam também considerar a participação desses elementos nos processos inclusivos. Em segundo lugar, porque se evidencia a potencialidade contida nesta interação e, no caso do presente estudo, como o próprio processo de desenvolvimento da criança com deficiência (aqui, a criança com déficit intelectual) é também propiciada a partir 
da relação com o par de idade. Os resultados discutidos em todas as três fases, mas especialmente na fase III, mostram como, ao longo do tempo, a interação se torna mais complexa, as aprendizagens se diferenciam e vão assumindo estruturas que permitem cada vez mais a participação das crianças pivô nas atividades e rotinas institucionais. Em terceiro lugar, porque possibilita a discussão de outros atores no processo de inclusão (inserção e participação nas atividades e vida escolar) - os pares, fortalecendo a compreensão de que as próprias crianças (co)constroem cultura, são ativas e participativas na constituição do outro, na constituição dos espaços e vivências em contextos escolares.

Metodologicamente, acredita-se que os resultados desse estudo ainda abrem espaço para se discutir sobre as possibilidades de se utilizar o recorte dos processos de regulação e corregulações de comportamento de pares, enquanto possibilidades para a investigação da participação de crianças com deficiência em contexto escolar regular. 


\section{Considerações finais}

Reconhece-se as limitações deste estudo a partir de reflexões sobre questões metodológicas, sobretudo no que tangencia a incorporação das diferentes fontes de informação no processo de análise do desenvolvimento das crianças com déficit intelectual. Neste sentido, mesmo em se trabalhando dentro de uma perspectiva que compreende o desenvolvimento pela sua complexidade que não só permite, como incentiva que o fenômeno seja investigado por meio dela, os resultados apresentados ainda são um recorte da realidade. Seria possível a partir dos resultados ainda levantar inúmeras outras questões sobre o processo de interação e sobre o percurso de desenvolvimento das crianças pivô e seus pares, que merecem atenção pela relevância teórica e pela possibilidade de impacto na construção de saberes sobre o processo de inclusão de crianças com déficit intelectual no âmbito da educação infantil.

Dessa forma, para futuras pesquisas dentro do campo da psicologia do desenvolvimento, se considera importante o desenvolvimento de uma articulação de metodologias para abordar os vários elementos que compõem o fenômeno das vivências (perezhivanie) das crianças ao longo do tempo. Ou ainda, pesquisas longitudinais que considerem as possibilidades de desenvolvimento a partir de diferentes contextos culturais, buscando evidenciar os elementos centrais do fenômeno do desenvolvimento humano a partir das interações de pares.

Por fim, considera-se de extrema relevância a interdisciplinaridade com o campo da Educação, ainda pouco explorado neste trabalho. Tal interdisciplinaridade abriria portas para o olhar sobre os elementos da cultura institucional escolar que estão intimamente relacionados aos processos de desenvolvimento estudados. Essa interdisciplinaridade possibilitaria a ampliação das discussões teóricas trazendo à tona questionamentos sobre práticas pedagógicas na promoção da interação de pares, divisão e utilização do espaço institucionallescolar, ou ainda, elementos de ordem das diferenças culturais que distinguem sistemas educacionais em diferentes países.

Considera-se que seja no entrelaçamento com o campo da educação que poderiam ocorrer ações práticas no sentido de aplicar os conhecimentos construídos através deste estudo para a melhoria da qualidade do serviço educacional oferecido a crianças com déficit intelectual na educação infantil, pois é no âmbito institucional escolar que a inclusão de fato ocorre e, portanto, é também junto a esse contexto que o conhecimento tem que ser (re)construído. 


\section{Bibliografia}

AAIDD - American Association on Intellectual and Development Disabilities. (2010). Intellectual Disability: Definition, Classification, and Systems of Supports. Eleventh Edition. American Association on Intellectual and Development Disabilities. Washington: AAIDD books

Allal, L. \& Ducrey, G. P. (2000). Assessment o for in the zone of proximal development. Learning and instruction, 10, 137-152.

Almeida M.A. (2004). Apresentação e análise das definições de deficiência mental propostas pela AAMR - Associação Americana de Retardo Mental de 1908 a 2002. Revista de Educação da Universidade Católica de Campinas, 16, 33-48.

Almeida, I. G. (2014). Processo de recepção e acolhida da criança em instituições de acolhimento: proteção elou (re)vitimização? Tese (Doutorado), Faculdade de Filosofia, Ciências e Letras de Ribeirão Preto, Universidade de São Paulo, Ribeirão Preto.

Amorim, K. S. \& Rossetti-Ferreira, M. C. (2008a). Corporeidade, significação e o primeiro ano de vida. Arquivos Brasileiros de Psicologia, 60(1), 67-81.

Amorim, K. S. \& Rossetti-Ferreira, M. C. (2008b). Dialogismo e a investigação de processos desenvolvimentais humanos. Paidéia USP. Ribeirao Preto. Impresso, 18, 235-250

Amorim, K. S. (2013). Linguagem, comunicação e significação de bebês. Tese de Livre docência. Universidade de São Paulo, Ribeirão Preto-SP.

Amorim, K. S. (2012). Processos de Significação no Primeiro Ano de Vida. Psicologia: Teoria e Pesquisa (UnB. Impresso),28, 45-53.

Amorim, K. S.; Costa, C. A.; Rodrigues, L. A.; Moura, G. G., \& Ferreira, L.D.P.M (2012). O bebê e a construção de significações, em relações afetivas e contextos culturais diversos. Temas em Psicologia, 20, 309-326.

Amorim, K. S.; Anjos, A. M. \& Rossetti-Ferreira, M. C. (2012). Processos interativos de bebês em creche. Psicologia: Reflexão e Crítica (UFRGS. Impresso), 25, 378-389.

Anache, A.A. \& Mitjáns, A. M (2007). Deficiência mental e produção científica na base de dados da CAPES: o lugar da aprendizagem. In Revista Psicologia Escolar e Educacional, 11(2), 253-274.

Anjos, A. M.; Amorim, K. S.; Franchi e Vasconcelos, C. R. \& Rossetti-Ferreira, M. C. (2004). Interações entre bebês em Creche. Estud. Psicol (Natal) 9(3), p. 513-522.

Aquino, F.S.B. \& Salomão, N.M.R. (2009). Contribuições da habilidade de atenção conjunta para a habilidade sócio infantil. Psicologia em Estudo, 7(2), 127-133.

Baldwin, D. A. (1995). Understanding the link between joint attention and language. In: C. Moore, P. J. Dunham (Eds), Joint Attention: Its Origins and Role in Development (pp. 131-158). Hillsdale, NJ: Erlbaum. 
Bakeman, R., \& Adamson, L. B. (1984). Coordinating attention to people and objects in mother-infant and peer-infant interaction. Child Development, 55, 1278-1289.

Bakhtin, M. (1981). Marxismo e filosofia da linguagem. São Paulo: Hecitec.

Bakhtin, M. (1997). Estética da criação verbal. São Paulo. Martins Fontes.

Banister, P. (1994). Qualitative methods in psychology: a research guide. In: H. Szymanski (Org), Entrevista na pesquisa em educação: a prática reflexiva (pp.25-32). Brasília: Liber livro.

Batista, M.W. \& Enuno, R.S.F. (2004). Inclusão escolar e deficiência mental: análise da interação social entre companheiros. Estudos de Psicologia , 9(1), 101-121.

Batista, C. G.; Cardoso, L. M. \& Santos M. R. A (2006). Procurando botões de desenvolvimento: avaliação de crianças com deficiência e acentuadas dificuldades de aprendizagem. Estudos de psicologia, 11, 297-305.

Barbosa, D. \& Zanella, A. V. (2005). Integrando análise de conteúdo e análise microgenética em pesquisas no campo psi: a constituição do sujeito como foco. Revista Psico, 36(2), 189-202

Bee, H. (1997). O ciclo vital. Rio de Janeiro. Artmed.

Bee, H. (2003). A criança em desenvolvimento. Rio de Janeiro. Artmed.

Behne, T.; Carpenter, M.; Call, J., \& Tomasello, M. (2005). Unwilling versus unable: Infants' understanding of intentional action. Developmental Psychology, 41(2), 328-337. Doi:10.1037/0012-1649.41.2.328

Bieler, C; Moura, M.L. S. (2000). Brincadeiras de um grupo de crianças do meio urbano do Rio de Janeiro / Play ground of de children from the urban context of Rio de Janeiro, Revista Dep Psicologia UFF, 12 (2/3), 29-44.

Bijou, S.W. \& Baer, D.M. (1965). Child Development: universal stage of infancy. USA: Meredith Publishing Company.

Bosa, C. (2002). Atenção Compartilhada e Identificação Precoce do Autismo, Psicologia: Reflexão e Crítica, 15(1), 77-88.

Boyd B. A.; Odom S. L.; Humphreys B. P. \& Sam A. M. (2010). Infants and toddlers with autism spectrum disorder: Early identification and early intervention. Journal of Early Intervention, 32, 75-98.

Brasil (1961). Ministério da Educação. Lei de Diretrizes e Bases da Educação Nacional. LDB 4.024, de 20 de dezembro de 1961.

Brasil (1988). Constituição da República Federativa do Brasil. Brasília: Imprensa Oficial.

Brasil (1990). Declaração Mundial sobre Educação para Todos: plano de ação para satisfazer 
as necessidades básicas de aprendizagem. UNESCO, Jomtiem/Tailândia.

Brasil (1994a). Declaração de Salamanca e linha de ação sobre necessidades educativas especiais. Brasília: UNESCO.

Brasil (1994b). Ministério da Educação. Secretaria de Educação Especial. Política Nacional de Educação Especial. Brasília: MEC/SEESP.

Brasil (1996). Ministério da Educação. Lei de Diretrizes e Bases da Educação Nacional. LDB 9.394, de 20 de dezembro de 1996.

Brasil. (2004). Ministério da Educação. Secretaria de Educação Especial. Decreto No 5.296 de 02 de dezembro de 2004.

Brasil (2006a). Comitê Nacional de Educação em Direitos Humanos. Plano Nacional de Educação em Direitos Humanos. Brasília: Secretaria Especial dos Direitos Humanos, Ministério da Educação, Ministério da Justiça, UNESCO.

Branco, A. U. A; Carvalho, A. M. A.; Gil, M. S. A. \& Pedrosa, M. I. (1989). Fluxo de interações entre crianças e uma situação de brinquedo em grupo. Psicologia, 15(1), 1327.

Bronfenbrenner, U. (1996) A ecologia do desenvolvimento humano: experimentos naturais e planejados. Porto Alegre: Artes Médicas.

Bruner, J. S. (1973). Organization of early skilled actions. Child development, 44(1), 1-11.

Bruner, J. S. (1975). From communication to language: a psychological perspective. Cognition, 3(3), 255-287.

Bruner, J. S. (1980). Early social interaction and language acquisition. In H. R. Schaffer (Ed.), Studies in mother-infant interaction (pp. 271-289). New York: Academic Press Inc.

Bruner, J. (1983). Child's talk: Learning to use language. New York: Norton.

Bruner, J. (1997). Atos de significação. Porto Alegre: Artes Médicas.

Butler, D.L. (1998). In search of the architect of learning: A commentary on scaffolding as a metaphor for instructional interactions. Journal of Learning Disabilities, 31(4), 274-385.

Butterworth, G. (1995). Origins of mind in perception and action. In C. Moore \& P. J. Dunham (Eds.), Joint attention: Its origins and role in development (pp. 29-40). Hillsdale, NJ: Lawrence Erlbaum Associates.

Buysse, V.; Goldman, B. D. \& Skinner, M. L. (2002). Setting effects on friendship formation among young children with and without disabilities. Exceptional Children, 68(4), 503517.

Cairns, R.B; Elder, G.H \& Costelo, E.J (Eds) (1996). Developmental Science. New York, Cambrigde University Press. 
Camaioni L.; Perucchini P.; Bellagamba F. \& Colennesi C. (2004). The role of deliberative pointing in developing a theory of mind. Infancy, 5, 291-308.

Camilli G., Vargas S., Ryan S., Barnett W. S. (2010). Meta-analysis of the effects of early education interventions on cognitive and social development. Teachers College Record, $112,579-620$

Carvalho, A.M.A. (1989). Etologia e comportamento social. Psicologia e Sociedade, 5(8), 145-163.

Carvalho, A.M.A.; Império-Hamburger, A. \& Pedrosa, M. I. (1996) Interação, regulação e corregulações no contexto do desenvolvimento humano: discussão conceitual e exemplos empíricos. Publicações IPUSP. pp.1-34.

Carvalho, A.M. A.; Bergamasco, N. H. P.; Lyra, M. da C.D. P.; Pedrosa, M. I.; Rubiano, M. Rubiano B.; Império-Hamburger, A.; Oliveira, Z de M.; Vasconcellos, V. M. R. (1996). Registro em vídeo na pesquisa em psicologia: reflexões a partir de relatos de experiência. Psicologia: Teoria e Pesquisa,12 (3), 261-267.

Carvalho; A.M.A; Branco, A.U; Pedrosa, M.I \& Gil, M.S.C (2002). Dinâmicas interacionais em grupos. Psicologia em estudo, 7, 91-99.

Carvalho, A. M. A. \& Pedrosa, M. I. (2002). Cultura no grupo de brinquedo. Estudos de Psicologia, 7(1), 181-188.

Carvalho, E. N. S \& Maciel, D. M. M. (2003). Nova concepção de deficiência mental segundo a American Association on Mental Retardation: AAMR: sistema 2002. Revistas Temas de psicologia SBP, 11(2), 147-156.

Carvalho, A. M. A. \& Rubiano, M. R. B. (2004). Vínculo e compartilhamento na brincadeira de crianças. In M. C. Rossetti-Ferreira, K. S. Amorim, A. P. S. Silva e Ana M. A. Carvalho (Eds) Rede de significações: uma perspectiva para o estudo do desenvolvimento humano (pp. 171187). POA: ArtMed.

Carvalho A.M.A.; Bastos A.C.S.B.; Rabinovich E. P. \& Sampaio S.M.R. (2006). Vínculos e redes sociais em contextos familiares e institucionais: Uma reflexão conceitual. Psicologia em Estudo, 11(3), 589-598. Doi:10.1590/S1413-73722006000300015

Cecato, J. F; Fiorese, B.; Bartholomeu, L.L.; Bastos, E. L.; Grogolato, A.M.S \& Martineli, J. E (2012). Inclusão social de um paciente com déficit intelectual moderado por meio de repertório verbal. Psicologia clínica, 24(2), 69-82.

Clayton, A. M. \& Thorne, T. (2000). Diary data enhancing rigour: analysis framework and verification tool. Journal of Advanced Nursing, 32: 1514-1521. Doi:10.1046/j.13652648.2000.01609.x

Cobb-Moore, C. (2008). Young children's social organization of peer interactions. $\mathrm{PhD}$ thesis, Queensland University of Technology. 
Colaço, V. F. R.; Pereira, E.; Neto, F. E. P.; Chaves, H. V. \& Santiago de Sá, T. (2007). Estratégias de mediação em situação de interação entre crianças em sala de aula. Estudos de Psicologia, 12 (1), 65-92.

Cole, C M.; Waldron, N \& Majd, M. (2004). Academic Progress of Students Across Inclusive and Traditional Settings. Mental Retardation, 42(2), 136-144.

Colus, K. M. (2012). Processos de estabelecimento da atenção conjunta em um bebê vidente e em outro com deficiência visual severa. Dissertação de Mestrado, Faculdade de Filosofia, Ciências e Letras de Ribeirão Preto, Universidade de São Paulo, Ribeirão PretoSP.

Corsaro, W., \& Molinari, L. (1990). From seggiolini to discussione: The generation and extension of peer culture among Italian preschool children. Qualitative Studies in Education, 3(3), 213-230.

Corsaro, W. (2003). We're friends right? Inside kids' culture. Joseph Henry Press. Washington, D.C.

Corsaro, W. (2005). The sociology of childhood. Bervelly Hills. Sage Publications.

Corsaro, W. (2009). Reprodução interpretativa e cultura de pares. In F. Müller; A. M. A. Carvalho, Ana Maria Almeida (Eds.). Teoria e Prática na pesquisa com crianças. Diálogos com William Corsaro (pp. 31-50). São Paulo: Cortez Editora.

Costa, L.H. F. M. (2000). Estágio sensório-motor e projetivo. In A. Mahoney e L.R. Almeida (Eds). Henri Wallon: Psicologia e Educação. São Paulo: Edicões Loyola.

Costa, C. A. \& Amorim, K. S. (2015). Abreviação em relações de bebês com seus pares de idade. Psicologia: Teoria e Pesquisa (UnB. Impresso), 31, 15-23.

Costa, C. A. (2012). Significações em relações de bebês com seus pares de idade. Dissertação (Mestrado em Psicologia) - Faculdade de Filosofia Ciências e Letras de Ribeirão Preto USP, Fundação de Amparo à Pesquisa do Estado de São Paulo.

Couchet, H. \& Vauclair, J. (2010). Pointing gestures in young children. Gesture, 10(2-3), 129149. Doi: $10.1075 /$ gest.10.2-3.02coc.

Dasen, P. R. \& Mishra, R. C. (2000). Cross -cultural view in human development in third millennium. International Journay of behavioral development. 24. 428-434.

Dainêz, D. (2009). A inclusão de crianças com deficiência mental: Focalizando a noção de compensação em Vygotsky. Dissertação de Mestrado. Unimep. Piracicaba-SP

Dainêz, C. (2014). Constituição Humana, deficiência e educação: Problematizando o conceito de compensação na perspectiva Histórico-Cultura. Tese de doutorado. Unicamp. Campinas-SP 
Dechichi, C. (2001). Transformando o Ambiente da Sala de Aula em um Contexto Promotor do Desenvolvimento do Aluno Deficiente Mental. Tese de doutorado. Universidade Pontifícia Católica de São Paulo.

Delafield-Butt, J. T. \& Trevarthen, C. (2013). Theories of the development of human communication. In P. Cobley \& P. Schultz (Eds.), Theories and Models of Communication (pp. 199-222). Berlin/Boston: De Gruyter Mouton.

De Jaegher H.; Di Paolo E. \& Gallagher S. (2010). Can social interaction constitute social cognition? Trends Cognitive Science, 14(10), 441-7. Doi: 10.1016/j.tics.2010.06.009

Dell'Isola, L. F. (2013). Expressões emocionais de desprazer no primeiro ano de vida: manifestações e processos de transformação. Dissertação de Mestrado, Faculdade de Filosofia Ciências e Letras da Universidade de São Paulo, Ribeirão Preto.

Dunst, C. J., \& Trivette, C. M. (2009). Using research evidence to inform and evaluate early childhood intervention practices. Topics in Early Childhood Special Education, 29, 4052.

Elias N. C.; Goyos, C.; Saunders M. D. \& Saunders, R. R. (2008). Teaching manual signs to adults with mental retardation using matching-to-sample procedures and stimulus equivalence. The Analysis of Verbal Behavior, 24, 1-13.

Embregts P.J.; Du Bois, M. G., \& Graef, N. (2010). Behavior problems in children with mild intellectual disabilities: an initial step towards prevention. Research in Developmental Disabilility,31(6),1398-403. Doi: 10.1016/j.ridd.2010.06.020

Eydam, A. \& Nurmsoo, E. (2014). Infant social learning theories: Taking the social part seriously. In: Enacting Culture: Embodiment, Interaction and the Development of Human Culture, 2014, Heidelberg.

Fani, T. \& Ghaemi, F. (2011). Implications of Vygotsky's zone of proximal development in teacher education: ZPTD and self-scafforing. Procedia - Social and Behavioral Science, 29, 1544-1559.

Facci, M. G. D. (2004). Valorização ou esvaziamento do trabalho do professor? Um estudo crítico-comparativo da teoria do professor reflexivo, do construtivismo e da psicologia vigotskiana. Campinas, SP: Autores Associados.

Fawcett, C. \& Liszkowski, U. (2012). Infants Anticipate Others' Social Preferences. Infant and Child Development, 21(3), 239-249. Doi:10.1002/icd.739

Ferguson, D. L. (2008). International trends in inclusive education: the continuing challenge to teach each one and everyone. European Journal of Special Needs Education, 23(2), 109-120. http://dx.doi.org/10.1080/08856250801946236

Ferri, C. \& Hostins, R. C. L. (2006). Currículo e diferença: processos de seleção e organização de conhecimentos para atendimento educacional de alunos com histórico de deficiência mental. 30 Reunião anual da ANPED, 1-19. 
Ferreira, J.R. \& Glat, R. (2003). Reformas educacionais pós-LDB: a inclusão do aluno com necessidades especiais no contexto da municipalização. In D. B Souza, \& L. C. M. Faria, (Eds) Descentralização, municipalização e financiamento da Educação no Brasil pós$L D B$ (pp. 372-390). Rio de Janeiro: Dp \& A.

Ferreira, M. (2005). “Branco demasiado” ou... reflexões epistemológicas, metodológicas e éticas acerca da pesquisa com crianças. Caxambú: ANPEd, [mimeo].

Ferreira, J. M.; Vectore, C. \& Dechichi, C. (2013). Mediação pedagógica como estratégia de atuação junto ao aluno do atendimento educacional especializado. In: C. Dechichi, L. Silva, \& J. M. Ferreira (Eds). Mediação pedagógica como estratégia de atuação junto ao aluno do atendimento educacional especializado. Uberlândia: EdUFU - Editora da Universidade Federal de Uberlândia, 55-74.

Ferreira, L. D. (2013). Expressões emocionais de desprazer no primeiro ano de vida: manifestações e processos de transformação. Dissertação de mestrado. Faculdade de Filosofia Ciências e Letras. Universidade de São Paulo - Ribeirão Preto.

Ferreira, J. M.; Mäkinen, M. \& Amorim, K.S. (2016). Intellectual disability in kindergarten: possibilities of development through pretend play. Procedia - Social and Behavioral Sciences, 217, 487-500. Doi.10.1016/j.sbspro.2016.02.024.

Feuerstein, R. \& Lewin-Benham, A. (2012). What learning looks like: Mediated learning in theory and practice K-6. Teachers College, Columbia University Press. New York.

Forman, E. A. \& Macphail, J. (1993).Vygotskian perspective on children's collaborative problem-solving activities. In E. A. Forman, N. Minick \& C. A. Stone (Eds), Context for learning: Social-cultural dynamics in children's development (pp. 213-229). New York: Oxford University Press.

Forman E. A. \& Cazden, C. B. (1985). Exploring Vygotskian perspective in education: the cognitive value of peer interaction. In J. V. Wertsch (Eds), Culture, communication and cognition: Vygotskian perspectives (pp. 323-347). Cambridge: Cambridge University Press.

Freitas, S. N. (2006). A formação de professores na educação inclusiva: construindo a base de todo processo. In: Rodrigues, D. (org) Inclusão e educação: doze olhares sobre a educação inclusiva (pp.74-85). São Paulo. Sammus Editora

Freitas, L. C \& Del Pretti, Z. A. P (2013). Habilidades sociais de crianças com diferentes necessidades educacionais especiais: Avaliação e implicações para intervenção. Avances en Psícologia Latino-americana, 31/2, 344- 362.

Fonseca, V. (1995). Educação especial, programa de estimulação precoce: uma introdução às ideias de Feuerstein. Porto Alegre; Atmed.

Furlan, R. (2004). Corpo, sentido e significação. In: M. C. Rossetti-Ferreira, K. S. Amorim, A. P. S Silva, \& A. M. A. Carvalho (Eds) Rede de Significações: e o estudo do desenvolvimento humano (pp. 51-56). Porto Alegre. Editora Artmed. 
Gallese, V. \& Goldman, A. (1998). Mirror neurons and the simulation theory of mind-reading. Trends in Cognitive Sciences, 2(12), 493-501.

Garcia, L. D (org) (2003). Psicología del desarrollo: adolescencia y juventude. Cidade de La Habana, Cuba: Editora Félix Varela.

Galvão. I. (2001). Expressividade e emoção: ampliando o olhar sobre as interações sociais. Revista Paulista de Educacão Física, 4, 15-31.

Garfinkle, A.N., \& Schwartz, I.S. (2002). Peer imitation: Increasing social interactions in children with autism and other developmental disabilities in inclusive preschool classrooms. Topics in Early Childhood Special Education, 22, 26-38.

Gartner, A. \& Riessman, F. (1993). Peer tutoring: towards a new model. ERIC Digest: Clearinghouse on Teacher and Teacher Education.

Gaskins, I. W.; Andreson R. C.; Pressley, M.; Cunicelli, E. A. \& Satlow, E. (1993). The moves and cycles of cognitive process instruction. Elementary School Journal, 93(3), 277-304.

Gesell, A. \& Amatruda, C. S. (2000). Psicologia do desenvolvimento do lactante e da criança pequena: bases neuropsicológicas e comportamentais. São Paulo: Editora Atheneu

Giangreco, M. F., \& Doyle, M. B. (2002). Students with disabilities and paraprofessional supports: Benefits, balance, and band-aids. Focus on Exceptional Children, 34(7), 1-12.

Gibson, E. J. (1988). Exploratory behavior in the development of perceiving, acting and the acquiring of knowledge. Ann. Rev. Psychol, 39, 1-41.

Goés, M. C. R. (2000). A abordagem microgenética na matriz histórico-cultural: uma perspectiva para o estudo da constituição da subjetividade. Cad. CEDES, 20(50), 9-25. Doi.org/10.1590/S0101-32622000000100002

Goés, M. C. R. \& Smolka, A. L. B. (1997). A significação nos espaços educacionais: interação social e subjetivação. Campinas: Papirus

González-Rey, F. (1995). Acerca de lo social y lo subjetivo en el socialismo. Revista Temas, $3,93-102$.

González-Rey, F. (2002). Sujeito e subjetividade. São Paulo: Thompson.

González-Rey, F. (2004a). O social na psicologia e a psicologia social: a emergência do sujeito. Petrópoles. Vozes.

González-Rey, F. (2004b). Sobre a Rede de Significações, o Sentido e a Pessoa: uma reflexão para o Debate. In M. C. Rossetti-Ferreira, K.S. Amorim, A.P.S. Silva, \& A. M. A. Carvalho, (Eds) Rede de Significações: e o estudo do desenvolvimento humano (pp. 5968). Porto Alegre. Editora Artmed

González-Rey, F. (2011). El pensamiento de Vigotsky: Contradicciones, desdoblamientos y desarrolllo. México. Trilhas. 
González-Rey, F. (2012). O social na psicologia e a psicologia no social: a emergência do sujeito. Tradução de Vera Lúcia Mello. Petrópolis, RJ; Editora Vozes.

González Rey, F. (2016). Vygotsky's concept of Perezhivanie in the Psychology of art and the final moments of his work: advancing his legacy. Mind, Culture and Activity, 1, 305314. Doi: 10.1080/10749039.2016.1186196

Gowen, J.W.; Johnson-Martin, N.; Goldman, B.D. \& Hussey, B. (1992). Object play and exploration in children with and without disabilities: a longitudinal study. American Journal of Mental Retard, 97(1), 21-38.

Gratiot-Alfandéry, H. (2010). Henri Wallon. Trad. Patrícia Junqueira. Recife: Fundação Joaquim Nabuco, Editora Massangana.

Gudzial, M.; Carlson, D. \& Turns, J. (1995). Facilitating learning with software-realized scaffolding for collaboration. In D. Budny, Eds. frontiers in education, $25^{\text {th }}$ Annual Conference, Atlanta, Georgia.

Guralnick, M. J., \& Groom, J. M. (1988). Peer interactions in mainstreamed and specialized classrooms: A comparative analysis. Exceptional Children, 54, 415-425.

Guralnick, M. J. (Ed) (2002). Interdisciplinary clinical assessment for young children with developmental disabilities. Baltimore: Brookes

Guralnick, M. J.; Neville, B; Hammond, M. A.; \& Connor, R. T. (2007). The friendships of young children with developmental delays: A longitudinal analysis. Journal of Applied Developmental Psychology, 28(1), 64-79.

Hanline, M. F. (1993). The inclusion of preschoolers with profound disabilities: An analysis of children's interactions. Journal of the Association for Persons with Severe Handicaps, $18,28-35$.

Hattier, M.; Matson, J. L.; Belva, B. \& Kozlowski, A. (2012). The effects of diagnostic group and gender on challenging behaviors in infants and toddlers with cerebral palsy, Down syndrome or seizures. Research in Developmental Disabilities, 33(1), 258-264.

Hinde, Robert. Aubrey. (1976). On describing relationships. Child Psychology and Psychiatry, 17, 1-19.

Holzman, L. (1997). Schools for Growth: Radical alternatives to current educational models. Mahwah, NJ: Lawrence Erlbaum Associates.

Holzman, L. (2010).Without creating ZPDs there is no creativity. In M. C. Connery, V. P. Jonh-Steiner, \& A. Marjanovic-Shane (Eds). Vygotsky and Creativity: A culturalhistorical approach to play, meaning making and the arts. New York: Peter Lang, 27-40.

Januzzi, G. M. (2004). A educação do deficiente no Brasil: dos primórdios ao início do século XXI. Campinas, SP Autores Assossiados. 
Jewitt, C. (2012). An Introduction to Using Video for Research. National Centre for Research Methods. London. Disponível em: http://eprints.ncrm.ac.uk/2259/4/NCRM_workingpaper_0312.pdf .

Jones, E. A. \& Carr, E. G. (2004). Joint attention in children with autism: Theory and intervention. Focus on autism and other development disabilities, 19. 13-26.

Kalliala, M. (2014). Toddlers both as more and less competent social actors in Finnish day care. Early Years: An International Research Journal. 34(1), 4-17, DOI:10.1080/09575146.2013.854320

Kamps, D. M.; Kravits, T.; Lopez, A. G.; Kemmerer, K.; Potucek, J., \& Harrel, L.G. (1998). What do the peers think? Social validity of peer-mediated programs. Education and Treatment of Children, 21 (2), 107-134.

Kasari, C.; Sigman, M.; Mundy, P. \& Yirmiya, N. (1990). Affective sharing in the context of attention interaction of normal, autistic, and mentally retarded children. Journal of Autism and Developmental Disorders, 20, 87-100.

Keith, H. \& Keith, K. D. (2013). Intellectual disability: Ethics, dehumanization and a new moral community. New Jersey:Wiley-Blackwell

Kemple, K. M. (2004). Let's be friends: Peer competence and social inclusion in early childhood programs. New York: Teachers College Press.

Kishimoto, T. M. (1995). O Jogo e a Educação Infantil. Pro-Posições (Unicamp), 70, 46-63.

Kishimoto, T. M. (1996). Froebel e a concepção de jogo infantil. Revista da Faculdade de Educação, 1(1), 145-168.

Kishimoto, T. M. (2000). Jogo, brinquedo, brincadeira e a educação. São Paulo: Editora Cortez, São Paulo.

Kishimoto, T. M. (2001). Uso de brinquedos e materiais pedagógicos nas escolas infantis de São Paulo. Infância e Educação, 3, 25-47.

Kozulin, A. (1990). Vygotsky's psychology: A biography of ideas. Cambridge, MA: Harvard University Press

Kozulin, A. (1998). Psychological tools: A sociocultural approach to education. Cambridge, MA: Harvard University Press

Kozulin, A. (2000). Diversity of instrumental enrichment applications. In A. Kozulin \& Y. Rand (Eds.), Experience of mediated learning (pp. 257-273). Oxford: Pergamom

Kozulin, A. (2003). Vygotsky's Educational Theory in Cultural Context. UK: Cambridge University Press.

Kronqvist, E. (1998). Children, culture and education. In: E. Hujala, (Eds). Childhood Education: International Perspectives. Oulu, Finland: Oulun Yliopistopaino, 42 - 49. 
Ledford, J. R.; Gast, D. L.; Luscre, D. \& Ayres, K. A. (2008). Observational and incidental learning for students with autism during small group instruction. Journal of Autism and Developmental Disabilities, 38, 86-103. Doi: 10.1007/s10803-007-0363

Lee, S., \& Odom, S.L. (1996). The relationship between stereotypic behavior and peer social interaction for children with severe disabilities. Journal of Association of Severely Handicapped, 21, 88-95.

Legerstee, M., \& Weintraub, J. (1997). The integration of person and object attention in infants with and without Down syndrome. Infant Behavior and Development 20, 71-82.

Leinonen, J. \& Sintonen, S. (2014). Productive participation - Children as active media producers in kindergarten. Nordic Journal of Digital Literacy. 9(3), 216-236.

Leontiev, A.N (2005a). The genesis of human thinking. Journal of Russian and East European Psychology, 43(5) 53-64.

Leontiev, A. N. (2005b). Os princípios do desenvolvimento mental e o problema do atraso mental. In A.R Luria; A.N. Leontiev, \& L. S. Vygotsky, Psicologia e pedagogia: bases psicológicas da aprendizagem e do desenvolvimento. São Paulo: Editora Centauro.

Lewis, M., \& Rosenblum, L. A. (Eds.) (1975). Friendship and peer relations. New York: Wiley.

Lewis, M. \& Takahashi, K. (2005). Beyond the Dyad: Conceptualization of Social Networks. Human Development, 48(5-7). Doi:10.1159/000083212)

Liszkowski, U.; Schäfer, M.; Carpenter, M. \& Tomasello, M. (2009). Prelinguistic infants, but not chimpanzees, communicate about absent entities. Psychological Science, 20, 654660.

Lindsay, G. (2007), Educational psychology and the effectiveness of inclusive education/mainstreaming. British Journal of Educational Psychology, 77: 1-24. Doi:10.1348/000709906X156881,

Logan, A. (2006). The role of the special needs assistant supporting pupils with special educational needs in Irish mainstream primary schools. Support for Learning, 21 (2), 1467-9604. Doi.org/10.1111/j.1467-9604.2006.00410.x

Loveland, K. A. (1987). Behavior of Down syndrome children before the mirror: Exploration. Child Development, 58(3), 768-78.

Lucena, J. (2010). Examinando os processos de assimilação, transformação, construção e compartilhamento de cultura entre crianças de dois anos no ambiente de creche. Dissertação de mestrado. Universidade Federal de Pernambuco, Recife.

Luria, A. R. (1973). The working brain. Harmondsworth, England: Penguin.

Luria, A. R. (1979). Curso de Psicologia Geral. Rio de Janeiro: Civilização Brasileira. 
Machado, A. C. \& Bello, S. F. (2015). Habilidades sociocomunicativas e de atenção compartilhada em bebês típicos da primeira infância. Revista Psicopedagogia, 32(98), 150-157.

Mäkinen, M. \& Mäkinen, E. (2011). Teaching in inclusive setting: towards collaborative scaffolding. La nouvelle revue de l' adaptation et de la scolarisation, 55(3), 57-74.

Maluf, M. R. \& Mozzer, G. N. S. (2000). Operações com signos em crianças de 5 a 7 anos. Psicologia: Teoria e Pesquisa (UnB. Impresso), 16(1), 63-69.

Mantoan, M. T. E. (1998). Educação escolar de deficientes mentais: problemas para a pesquisa e o desenvolvimento. Cad. CEDES, Campinas, 19(46), 110-129.

Mantoan, M. T. E. (2006). O direito de ser, sendo diferente na escola. In D. Rodrigues (Org) Inclusão e educação: Doze olhares sobre a educação inclusiva (pp.25-32). São Paulo: Sammus Editora.

Marjanovick-Shane, A. \& Beljanski-Ristic, L. (2008). From play to Art - From experience to insight. Mind, Culture and Activity, 15(2), 93-114.

Marjanovick-Shane, A. (2010). From yes and no to me and you: a playful change in relationship and meanings. In M. C. Connery, V. P. Jonh-Steiner \& A. MarjanovickShane (Eds). Vygotsky and creativity: A cultural-Historical approach to play, meaning making and the arts. (pp. 41-59). New York: Peter Lang.

Marques, L. P. (2001). O professor do aluno com deficiência mental: concepções e práticas pedagógicas. Juiz de Fora/ MG, Editora da UFJF.

Mazzotta, M. J. S. (1987). Educação Escolar: comum ou especial? São Paulo: Pioneira

Mazzotta, M. J. S. (2001). Educação especial no Brasil: história e políticas públicas. São Paulo: Cortez.

Mello, C.B.; Argollo, N.; Shayer, B.P.M.; Abreu, N.; Godinho, K.; Duran, P.; Vargem, F.; Muszkat, M.; Miranda, M.C. \& Bueno, O.F.A. (2011). Versão Abreviada do Wisc III: correlação entre QI estimado e QI total em crianças brasileiras. Psicologia Teoria e Pesquisa, 27(2), 149-155.

Mello, S. (2011). A infância e humanização: algumas considerações na perspectiva históricocultural. Perspectiva, 83-110.

Mendes, E.G. (2010). Inclusão marco zero: começando pelas creches. Campinas: Autores Associados.

Minayo, M. C. S. (2006). O desafio do conhecimento. São Paulo: Editora Hucitec.

Monteiro, M. I. B. \& Freitas, A. P. (2014). Processos de significação na elaboração de conhecimento em alunos com necessidades educacionais especiais. Educação e Pesquisa, 40(1), 95-107. 
Morin, E. (1996). Ciência com consciência. Rio de Janeiro: Bertrand do Brasil.

Moura, M. L S. \& Ribas, A. F. P. (2002). Imitação e desenvolvimento inicial: evidências empíricas, explicações e implicações teóricas. Estudos de Psicologia, 7(2), 207-215.

Moura, M. L. S. (2009). Interações sociais e desenvolvimento. In M. L. Seidl-de-Moura, D. M. L. F. Mendes, \& L. F. Pessôa. Interação social e desenvolvimento (pp. 20-36). Rio de Janeiro: Editora CRV.

Moura, G. G. (2012). Quem não pega, não se apega? O acolhimento institucional de bebês e as (im)possibilidades de construção de vínculos afetivos. Dissertação (Mestrado em Psicologia) - Faculdade de Filosofia Ciências e Letras de Ribeirão Preto - USP, Fundação de Amparo à Pesquisa do Estado de São Paulo. Orientador: Katia de Souza Amorim.

Moura, G.G. \& Amorim, K. S. (2013). A (in)visibilidade dos bebês na discussão sobre acolhimento institucional. Estudos de Psicologia (PUCCAMP. Impresso), 18, 235-245.

Mundy, P.; Card, J., \& Fox, N. (2000). EEG Correlates of the development of infant joint attention skills. Development Psychobiology, 36, 325-338.

Nadel, J. (1986). Imitation et communication entre jeunes enfants. Paris: PUF.

Nadel, J. \& Baudonnière, P. (1981). Imitação modo preponderante de intercâmbio entre pares durante o terceiro ano de vida. Cadernos de Pesquisa, São Paulo, 39, 26-31.

Nadin, S. and Cassell, C. (2006) 'The use of a research diary as a tool for rflexive practice', Qualitative Research in Accounting \& Management, 3(3), 208-217. Doi: 10.1108/11766090610705407.

Newman, F. \& Holzman, L. (2002). Lev Vygotsky: cientista revolucionário. Tradução de Marcos Bagno. São Paulo: Loyola.

Ninio, A., \& Bruner, J. (1978). The achievement and antecedents of labelling. Journal of Child Language, 5, 1-16

Novack, \& Goldin-Meadow, (2015). Learning from gesture: How our hands change our minds. Educational Psychology Review, 27(3), 405-412. Doi: 10.1007/s10648-015-93253

Nurmsoo, E., Eydam, A., Leahy, V., \& Burton, T. (2014). Children's high-fidelity imitation of tool vs non-tool actions. In XIX Biennial International Conference on Infant Studies. Berlin, Germany.

Odegaard, E. E. (2012). Researching the youngest children as meaning-makers: How can conarrative approach give data? 22th European Early Childhood Education Research Association Conference Book. Porto, Portugal. Porto Editora, 36.

Odom, S. L., Brown, W. H., Schwartz, I. S., Zercher, C., \& Sandall, S. R. (2002). Classroom ecology and child participation. In S. L. Odom (Ed.), Widening the circle: Including 
children with disabilities in preschool programs (pp. 25-45). New York: Teachers College Press.

Oliveira-Formosinho, J. \& Formosinho, J. (2012). Pedagogy-in-participation: childhood association educational perspective. Porto, Portugal. Porto Editora.

Oliveira, M. K. \& Teixeira, E. (2002). A questão da periodização do desenvolvimento psicológico. In M. K. Oliveira, D. T. Souza \& T. C. Rego, Psicologia, educação e as temáticas da vida contemporânea. São Paulo: editora Moderna.

Oliveira, M. K. (1999). Vygotsky, aprendizado e desenvolvimento: Um processo sóciohistórico. São Paulo. Editora Scipione.

Oliveira, Z. M. R. (2011). Jogo de papéis: um olhar para as brincadeiras infantis. São Paulo: Editora Cortez

Oliveira, Z. M. R.; Guanaes, C. \& Costa, N. R. A. (2004). Discutindo o Conceito de "Jogos de Papéis": uma interface com a Teoria do Posicionamento. In M. C. Rossetti-Ferreira, K. S. Amorim, A. P. Souza \& A.M.A Carvalho (Eds), Rede de Significações e o Estudo do Desenvolvimento Humano (pp. 69-80). Porto Alegre: Artmed.

Palacios, J. (1995). O que é a adolescência. In: C. Coll, J. Palacios \& A. Marchesi (Eds), Desenvolvimento psicológico e educação: psicologia evolutiva (pp. 263 - 272). Porto Alegre: Artes Médicas.

Pálmadóttir, A. M. L. (2012). Toddler in pre-school: social interactions and relation in play. 22th European Early Childhood Education Research Association Conference Book. Porto, Portugal. Porto Editora, 61.

Paulus, M. (2011). Imitation in infancy: conceptual considerations, Theory \& Psychology, 21(6), 848-856.

Paulus, M.; Hunnius, S.; Vissers, M. \& Bekkering, H. (2011). Imitation in infancy: rational or motor resonance? Child Development,82(4), 1047-57. Doi: 10.1111/j.14678624.2011.01610.x.

Pedrosa, M. I. \& Carvalho, A. M. (1995). A interação social e a construção da brincadeira. Caderno de Pesquisa São Paulo, 93, 60-65.

Pedrosa, M. I. (1996). Coletâneas da ANPEPP: Investigação da criança em interação social. Recife: Editora Universitária da UFPE.

Pedrosa, M.I. \& Carvalho, A.M.A. (2005). Análise qualitativa de episódios de interação: uma reflexão sobre procedimentos e formas de uso. Psicologia: Reflexão e Crítica (UFRGS. Impresso), 18(3), 431-442.

Pedrosa, M. I \& Carvalho, A. M. A. (2006). Construction of communication during young children's play. Revista de Etiologia, 8(1), 1-11. 
Pedrosa, M. I. \& Carvalho, A.M. A. (2009). Aprendendo sobre eventos físicos com parceiros de idade. Psicologia USP, 20(3), 355-373.

Pedrosa, M. I. \& Santos, M. F. (2009). Aprofundando reprodução interpretativa e cultura de pares em diálogo com Corsaro. In Müller; A. M. A. Carvalho, Ana Maria Almeida (Eds.). Teoria e Prática na pesquisa com crianças. Diálogos com William Corsaro (pp. 51-58). São Paulo: Cortez Editora.

Pessotti, I. (1984). Deficiência Mental: da superstição à ciência. São Paulo:EDUSP.

Pfister, M.; Moser-Opitz, E. \& Pauli, C. (2015). Scaffolding for mathematics teaching in inclusive primary classrooms: a video study. ZDM Mathematics Education, 47(7), 10791092. Doi:10.1007/s11858-015-0713-4

Piaget, J \& Inhelder, J. B. (1978). A psicologia da criança. São Paulo: DIFEL.

Piaget, J. (1965). Origins of intelligence in the child. (Trad. Margaret Cook) New York; International University Press.

Pianta R. C.; Barnett W. S.; Burchinal M., \& Thornburg K. R. (2009). The effects of preschool education: What we know, how public policy is or is not aligned with the evidence base, and what we need to know. Psychological Science in the Public Interest, 10, 49-88

Pino, A. (2000). O social e o cultural na obra de Vigotski. Educação \& Sociedade, 21(71), 45-78.

Pino, A. (2005). Cultura e Desenvolvimento humano. Viver mente\&cérebro - Memória da Pedagogia, 1(2) 14-21.

Pletsch, M. D. (2010). Repensando a inclusão escolar: diretrizes políticas, práticas curriculares e deficiência intelectual. Rio de Janeiro: Nau Edur.

Pletsch, M. D. \& Braun, P. (2008). A inclusão de pessoas com deficiência mental: um processo em construção. Democratizar. 2(2), 21-43.

Prestes, Z. (2010). Quando não é quase a mesma coisa: Análise das traduções de Lev Vygotsky no Brasil, repercussões no campo educacional. Tese de Doutorado. Universidade de Brasília. Brasília.

Prestes, Z. (2012). Quando não é quase a mesma coisa: traduções de Lev Semionovitch Vigotski no Brasil. Campinas, SP: Autores Associados.

Prestes, Z.; Tunes, E. \& Nascimento, R. (2013). Lev Semionovitch Vigotski: um estudo da vida e obra do criador da psicologia histórico-cultural. In: A. M. Longarezi, R. V. Puentes, (Eds) Ensino desenvolvimental: vida, pensamento e obra dos principais representantes russos. Uberlândia: EDUFU, 47-65.

Prieto, R. G.; Pagnez, K. S. M. M. \& Gonzalez, R. K. (2014). Educação especial e inclusão escolar: tramas de uma política em implantação. Educação e Realidade, 39, 725-743. 
Raittila, R. (2012) "With Children in Their Lived Space: Children's Actions as Research Data" International Journal of Early Years Education. 20 (3):p. 270-279.

Reddy, V.\& Trevarthen, C. (2004). What we learn about babies from engaging their emotions. Zero to Three, 24(3), 9-15.

Reddy, V. (2010). How infants know minds. Cambridge: Harvard University Press.

Reddy, V. (2012). Moving others matter. In A.D. Folen, M. L. Ulrike, T. P. Racine \&J. Zlatev (Eds), Moving ourselves moving others: motion and emotion in intersubjectivity, consciousness and language (pp. 139-163). Amsterdam: John benjamins Publishing Company.

Reddy, V. (2015). Joining intentions in infancy. Journal of Cousciousness Studies, 22(1-2), 24-44.

Reddy, V. \& Mireault, A. (2015). Teasing and clowning in infancy. Current Biology, 25(1), 20-32.

Rego, T. C. (1999). Vygotsky: Uma Perspectiva Histórico-Cultural da Educação. 7. ed. Petrópolis: Vozes.

Rodrigues, L. A. (2011). Processos de (trans)formação da comunicação e linguagem, ao longo dos cinco meses anos de vida: um estudo de caso. Dissertação (Mestrado em Psicologia) - Faculdade de Filosofia Ciências e Letras de Ribeirão Preto - USP, Fundação de Amparo à Pesquisa do Estado de São Paulo.

Rodd, J. (1998). Children, culture and education. In: Hujala, Eeva (org). Childhood Education: International Perspectives (pp. 33 - 41). Oulun Yliopistopaino; Oulu, Finland.

Rogers, S. J.; Hepburn, S. L.; Stackhouse, T., \& Wehner, E. (2003). Imitation performance in toddlers with autism and those with other developmental disorders. Journal of Child Psychology and Psychiatry, 44, 763-781. Doi: 10.1111/1469-7610.00162

Roriz, T. M. de S. (2005). Inclusão/exclusão escolar de crianças com epilepsia: perspectivas dos pais, professores e das próprias crianças. Tese (Doutorado em Psicologia) Faculdade de Filosofia, Ciências e Letras de Ribeirão Preto, Ribeirão Preto, SP.

Rose, J. (2010). Carer reports of the efficacy of cognitive behavioral interventions for anger. Research in Developmental Disabilities, 31, 1502-1508.

Rossetti-Ferreira, M. C.; Amorim, K. S.; Silva, A. P. S. (2000). Uma Perspectiva TeóricoMetodológica para a Análise do Desenvolvimento Humano e do Processo de Investigação. Psicologia. Reflexão e Crítica, 13, 281-293.

Rossetti-Ferreira, M. C.; Amorim, K. S.; Silva, A. P. S \& Carvalho, A. M. A (Eds). (2004). Rede de Significações: e o estudo do desenvolvimento humano. Porto Alegre. Editora Artmed. 
Rossetti-Ferreira, M. C.; Amorim, K. S. \& Silva, A. P. S. (2004) Rede de Significações: alguns conceitos básicos In: M. C. Rossetti-Ferreira; K. S. Amorim; A. P. S. Silva \& A. M. A. Carvalho (Org), Rede de Significações: e o estudo do desenvolvimento humano (pp. 2334). Porto Alegre. Editora Artmed.

Rossetti-Ferreira, M. C (2004). Seguindo a receita do poeta tecemos a Rede de Significações e este livro. In M. C. Rossetti-Ferreira; K. S. Amorim; A. P. S. Silva \& A. M. A. Carvalho (Org), Rede de Significações: e o estudo do desenvolvimento humano (pp. 15-22). Porto Alegre. Editora Artmed.

Rossetti-Ferreira, M.C.; Amorim, K.; Soares-Silva, A.P. \& Oliveira, Z.M. R. (2008) Desafios metodológicos na perspectiva da rede de significações. Cadernos de Pesquisa, 38(133), 147-170.

Rosiek, J. (2003). Emotional scaffolding: an exploration of the teacher knowledge at the intersection of student emotional and the subject matter. Journal of Teacher Education, 54(5), 399-412.

Rossit, R. A. S.; Goyos, A. C. N. (2009). Deficiência intellectual e aquisição matemática: currículo como rede de relações condicionais. Psicologia Escolar e Educacional, v. 13, p. 1-15.

Rucinska, Z. (2014). What guides pretence? Towards the interactive and the narrative approaches. Phenomenology and the Cognitive Sciences, 13 (3), 117-125.

Rueda, R. \& Genzuk, M. (2007). Sociocultural scaffolding as a means towards academic selfregulation: Paraeducators as cultural brokers. Focus on Exceptional Children, 40(3). 1-7.

Rumelhart, D. E. \& McClelland, J. L.(1986). Parallel distributed processing: Explorations in the microstructure of cognition. Denver: Bradford books

Rutanen, N. (2009). Crianças de dois anos de idade como coconstrutoras de cultura. Psicologia USP, 20(3), 375-387.

Rutanen, N. (2011). Space for toddlers in the guidelines and curricula for early childhood education and care in Finland. Childhood 18(4), 526-539. Doi: $10.1177 / 0907568211399366$

Rutanen, N. (2012). Socio-spatial practices in a Finnish daycare group for one- to three-yearolds. Early Years, 32(2), 201-214.

Rutanen, N. (2014). Lived Spaces in a toddler group: Application of Lefebvre's Spacial Triad. In: L.J. Harrison \& J. Sumsion (Eds), Lived Spaces of Infant-Toddler Education and Care: International Perspectives on Early Childhood Education and Development (pp.17-28). Springer. Doi 10.1007/978-94-017-8838-0_2

Rutanen, N.; Colus, K. M.; Amorim, K. S. \& Piattoeva, N. (2014). What is Best for the Child? Early Childhood Education and Care for Children under Three Years of Age in Brazil and in Finland. International Journal of Early Childhood, 46(2),123-141. 
Rutanen, N.; Costa, C. A., \& Amorim, K. d. S. (2016). Instructional Strategies, Discipline and Children's Participation in Educational Institutions for Children under Three-Years-Old: Cases from Brazil and Finland. International Journal of Humanities and Social Science, 6 (6), 204-215.

Saullo, R. F. M.; Rossetti-Ferreira, M. C.; Amorin, K. S. (2013). Cuidando ou tomando cuidado? agressividade, mediação e constituição do sujeito - um estudo de caso sobre um bebê mordedor em creche. Pró-Posições (UNICAMP. Impresso), 24, 81-98.

Sant'Ana, R. B. (2010). Criança-sujeito: experiência de pesquisa com alunos de escolas públicas. In Souza, M. P. R. Ouvindo crianças na escolar: abordagens qualitativas e desafios metodológicos para a psicologia. São Paulo. Casa do Psicólogo.

Sant'Ana, R. B. (2007). A dimensão social na formação do sujeito na psicologia. Memorandum, 12, 125-142.

Sassaki. R. K. (1997). Inclusão: Construindo uma sociedade para todos. Rio de Janeiro: WVA.

Sassaki, R. K. (2007). O direito à educação inclusiva, segundo a ONU. A Convenção sobre os Direitos das Pessoas com Deficiência Comentada. Brasília: Corde.

Saxe, Gearhart, Note \& Paduano, (1993). Peer interaction and the development of mathematical understanding: a new framework for research and educational practice. In H. Daniels (Ed), Charting the agenda: Vygotskyan perspectives (pp. 107-149). London: Routledge

Selby, J. M., \& B. S. Bradley. (2003). Infants in Groups: A Paradigm for the Study of Early Social Experience. Human Development 46, 197-221.

Sheridan, S. (2011). Pedagogical quality in preschool: A commentary. In N. Pramling \& I. Pramling Samuelsson (Eds.), Educational encounters: Nordic studies in early childhood didactics (pp. 223-242), Dordrecht, The Netherlands: Springer.

Schimiz, A. J. (2012). Brincadeira livre e ação educativa na infância. In: Coutinho, A. S.; Day, G. \& Wiggers, V. (org) Práticas pedagógicas na educaçao infantile: diálogos possíveis a partir da formação professional. Editora Nova Harmonia e Editora Oikos, São Leopoldo, Rio Grande do Sul.

Scorsolini-Comin, F. \& Amorim, K. S. (2010). Em meu gesto existe o teu gesto: corporeidade na inclusão de crianças deficientes. Psicologia Reflexão e crítica,23(2), 261-280.

Schilling, T. H., \& Clifton, R. K. (1998). Nine-month-old infants learn about a physical event in a single session: Implications for infants' understanding of physical phenomena. Cognitive Development, 13(2), 165-184.

Scorsolini-Comin F. \&Amorim, K. S. (2010). 'Em meu gesto existe o teu gesto': corporeidade na inclusão de crianças deficientes. Psicologia: Reflexão e Crítica (UFRGS. Impresso), 23, 261-269. 
Shakespeare, T. \& Watson, N. (2001). The social model of disability: an outdated ideology? Research in Social Science and Disability volume 2, pp 9-28

Silvers, A.; Wasserman, D. \& Mahowald, M. B (1998). Disability, Difference, Discrimination: Perspectives on justice on bioethics and public policy. Maryland USA. Rowman \& Littlefield Publishers.

Silva, A. P; Rossetti-Ferreira, M. C. \& Carvalho, A. M. A. (2004). Circunscritores: limites e possibilidades no desenvolvimento. In: M. C. Rossetti-Ferreira; K.S. Amorim; A. P. Silva, \& A. M. A. Carvalho (Eds), Rede de Significações: e o estudo do desenvolvimento humano (pp. 81-92). Porto Alegre. Editora Artmed.

Silva, L. C. (2009). Políticas públicas e formação de professores: Vozes e Vieses da Educação Inclusiva. Tese de doutorado. Faculdade de Educação. Universidade Federal de Uberlândia, Uberlândia, MG.

Smolka, A. L. B. (1995). A concepção de linguagem como instrumento: um questionamento sobre práticas discursivas e educação formal. Temas em Psicologia, 3(2), 11-21.

Smolka, A.L. B. (2002). O desenvolvimento cultural da criança: mediação, dialogia e (inter)regulação. In: M. K. Oliveira, D. T. Souza, \& T. C. Rego (Eds.). Psicologia, educação e as temáticas da vida contemporânea (pp. 77-94). São Paulo: Moderna.

Smolka, A. L.B (2004). Sentido e significado: uma contribuição à Rede de Significações. In M. C. Rossetti-Ferreira; K. S. Amorim; A. P. S. Silva, \& A. M. A. Carvalho (Orgs), Rede de Significações: e o estudo do desenvolvimento humano (pp. 35-50). Porto Alegre. Editora Artmed

Smolka, A. L. B.; Amorim, K. S. \& Leite, S. A. S. (2016). Questões de desenvolvimento humano na perspectiva histórico-cultural: bebê, criança e adultos em foco. In A.L.B Smolka \& S.A.S. Leite (Orgs.), Psicologia do Desenvolvimento: teorias e práticas em diferentes contextos (pp. 71-114). Campinas: Mercado das Letras.

Schmidt, S. (2011). Theorizing place: Students' navigation of place outside the classroom. Journal of Curriculum Theorizing, 27(1), 20-34

Solovieva, Y. \& Quintanar Rojas, L. (Org) (2010). Antologia del desarrollo psicológico del niño en edad preescolar. México: Trilhas.

Souza, C. M. L. \& Batista, C. G. (2008). Interação entre crianças com necessidades especiais em contexto lúdico: possibilidades de desenvolvimento. Psicologia: Reflexão e Crítica, 21(3), 383-391. Doi.org/10.1590/S0102-79722008000300006

Souza, F. C.; \& Prieto, R. G. (2016). Plano Nacional de Educação e Educação Especial. Journal of Research in Special Educational Needs, 16, 841-845.

Soja, Edward. 1996. Thirdspace: Journey to Los Angeles and Other Real-and-Imagined Places. Cambridge: Blackwell. 
Spyrou, S. (2011). The limits of children's voices: From authenticity to critical, reflexive representation. Childhood 18(2): 151-165.

Strain P. S., Bovey E. H. (2011). Randomized, controlled trial of the LEAP model of early intervention for young children with autism spectrum disorders. Early Childhood Special Education, 31, 133-154.

Szymanski, H. (Ed) (2004). Entrevista na pesquisa em educação: a prática reflexiva. Brasília: Liber livro

Talizina, N. F. (2009). Aplication de la teoria de la actividad a la ensenanza. México: Universidade Autonoma de Puebla.

Tébar, L. (2011). O perfil do professor mediador: pedagogia da mediação. São Paulo: Editora Senac SP.

Terpstra, J., \& Tamura, R. (2008). Effective social interaction strategies for inclusive settings. Early Childhood Education Journal, 35, 405-411. Doi: 10.1007/s10643-007-0225-0

Toassa, G. (2009). Emoções e vivências em Vygotsky: investigação para uma perspectiva histórico-cultural. Tese de doutorado, Faculdade de Filosofia Ciências e Letras, Universidade de São Paulo. São Paulo.

Tomasello, M. (1988). The role of joint attention processes in early language development. Language science, 10, 69-88.

Tomasello, M. (1995). Joint attention as social cognition. In C. Moore \& P. J. Dunham (Eds.), Joint attention: Its origins and role in development (pp. 103-130). Hillsdale, $\mathrm{N} \mathrm{J}$ : Lawrence Erlbaum Associates.

Tomasello, M. (1999). The cultural origins of human cognition. Cambridge: Harvard University Press.

Tomasello, M. (2003). Origens culturais da aquisição do conhecimento humano. São Paulo: Martins Fontes.

Tomasello, M., \& Farrar, M. (1986). Joint Attention and Early Language. Child Development, 57(6), 1454-1463. Doi:10.2307/1130423

Tomasello, M.; Kruger, A., \& Ratner, H. (1993). Cultural learning. Behavioral and brain science, 16, 495-552.

Tomasello, M.; Carpenter, M.; Call, J.; Behne, T. \& Moll, H. (2005). Understanding and sharing intentions: The origins of cultural cognition, Behavioral and Brain Sciences, 28(5), 675-691. Doi: 10.1017/S0140525X05000129.

Tomasello, M.; Carpenter, M. \& Liszkowski, U. (2007). A new look at infant pointing. Child Development, 78, 705-722. 
Tudge, J. R. H. (1990). Vygotsky, the zone of proximal development and peer collaboration for classroom practice. In L.C. Moll (Ed), Vygotsky and education: Instructional implications and applications of socialhistorical psychology (pp. 155-272), Cambridge: Cambridge University Press.

Tudge, J. R. H. (2008). The everyday life of young children: culture class and child rearing in diverse societies. New York: Cambridge University Press.

Trevarthen, C. (1979). Communication and cooperation in early infancy: a description of primary intersubjectivity. In: M. Bullowa (Ed). Before Speech: The Beginning of Human Communication (pp. 321-347). Cambridge, UK: Cambridge University Press.

Trevarthen, C. (1993). The function of emotions in early infant communication and development. In J. Nadel \& L Camaioni (Eds), New perspectives in early childhood communicative development (pp. 48-81); New York: Routledge.

Trevarthen, C. (1999). Musicality and the intrinsic motive pulse: Evidence from human psychobiology and infant communication. Musicae Scientiae (Special Issue 1999-2000), $155-215$.

Trevarthen, C. (2005). Action and Emotion in Development of Cultural Intelligence: Why Infants Habe Feelings like Ours. In J. Nadel \& D. Muir (Eds), Emotional Development (pp. 61-91). Oxford: Oxford University Press.

Trevarthen, C \& Aitken, K. J. (2001). Infant intersubjectivity: Research, Theory and Clinical Application. Child Psycholo.Psychiatric, 42 (1), 3-48.

Trevarthen, C. \& Malloch, S. (2002). Musicality and music before three: human vitality and invention shared with pride. Zero to Three, 23(1), 10-18

Uithol, S. \& Paulus, M. (2013). What infants understand of other's action? A theoretical account of early social cognition. Psychological Research. Doi: 10.1007/s00426-0130519-3

Unesco (1994). The Salamanca Statement and framework for action on special needs education. Paris: UNESCO - United Nations Educational, Scientific and Cultural Organization

Van Der Veer, R. (1996). The concept of culture in Vygotsky's thinking. Culture and Psychology, 2(3), 247-263.

Van Der Veer, R. \& Valsiner, J. (2014). Vygotsky: uma síntese. (7ª edição). São Paulo: Editora Loyola.

Valsiner, J. (Ed.) (1992). Child development within Culturally Structured Environments. Vol 3. Comparative Cultural and Constructivist Perspective. Norwood, NJ: Ablex.

Valsiner, J. (1993). Irreversibility of time and the construction of historical development psychology. Paper presented at the Behavioral Development, Recife, Pernambuco, 1923 . 
Valsiner, J. (2000). Culture and human development. Great Britain: Sage.

Valsiner, J., \& Van Der Veer, R. (1993). The encoding of distance: the concept of Zone of proximal development and its interpretation. In R. R. Coking \& K. A. Renninger, The development and meaning of psychological distance, (pp. 35-62). Hillsdale: Erlbaum.

Vasconcellos, V. M. R. \& Valsiner, J (1995) Perspectiva Co-construtivista na psicologia e na educacão. Porto Alegre, RS, Brasil: Artes Médicas.

Vasconcellos, V. M. R. (1996). Wallon e o papel da imitação na emergência de significado no desenvolvimento infantil. In M. I. Pedrosa (Org), Investigação da criança em interação social (pp. 33-47). Rio de Janeiro: Associação Nacional de Pesquisa e Pósgraduação em Psicologia.

Verba, M. (1994). The beginnings of collaboration in peer interaction. Human Development, $37(3), 125-139$.

Veresov, \& Fleer, (2016). Perezhivanie as a theoretical concept for researching young children's development. Mind, Culture, and Activity: An International Journal. 23(4), 111 .

Vieira, A. M. (2015). Currículo e arquitetura escolar: olhares cruzados na educação infantil. Curitiba: Editora CRV

Vuorisalo, M.; Rutanen, N., \& Raittila, R. (2015). Constructing relational space in early childhood education. Early years: an international journal of research and development, 35 (1), 67-79. doi:10.1080/09575146.2014.985289

Vygotsky, L.S (1989). Obras escogidas: Fundamentos de defectologia. Tomo V. Obras completas. Trad. C.P. Fernandez. Havana. Pueblo y Educacion.

Vygotsky, L. S. (1995). Historia del desarrollo de las funciones psiquicas superiores. In A. Alvarez \& P. Del Rio (Eds.), Obras escogidas III (Colección Aprendizaje, V. CXV). Madrid: Visor.

Vygotsky, L. S (1996). Teoria e método em psicologia. São Paulo: Martins Fontes.

Vygotsky, L.S (1997). Obras escogidas: fundamentos de defectología. Tomo V. Madrid: Visor.

Vygotsky, L. S (2001). Psicologia da arte. Trad. Paulo Bezerra. São Paulo. Martins Fontes.

Vygotsky, L. S. (2001). Pensamento e palavra. In: Vygotsky, L. S. A construção do Pensamento e da Linguagem. São Paulo: Martins Fontes. (Original publicado em 1934).

Vygostky, L. S (2002). Psirrologuia. Moskva, Eksmo. In Z. Prestes, Quando não é quase a mesma coisa. Campinas, SP. Autores Associados.

Vygotsky, L. S. (2004a). Imagination and creativity in childhood. Journal of Russian and Eastern European Psychology, 42(1), 7-97. 
Vygotsky, L. S. (2004b). The collective as a factor in the development of the abnormal child. In R. W. Rieber \& D. K. Robinson (Eds), The essential Vygotsky (pp. 201-219) New York: Kluwer AcademiclPlenum Press.

Vygotsky, L. S. (2004c). Teoria de Las emociones: estúdio histórico-psicológico. Trad. Judith Viaplana. Três Cantos Madri/Espana.

Vygotsky, L.S. (2005). Pensamento e linguagem. Jefferson Luiz Camargo (Trad). São Paulo: Editora Martins Fontes.

Vygotsky, L. S. (2007). A formação social da mente. (Trad. José Cipolla Neto, Luis S. M. Barreto, Solange C. Afeche). São Paulo: Martins Fontes.

Vygotsky, L. S (2008). A brincadeira e o seu papel no desenvolvimento psíquico da criança. Revista Virtual de Gestão de Iniciativas Sociais, (8), 18-36.

Vygotsky, L. S (2010). Psicologia Pedagógica. Trad. Paulo Bezerra. $3^{\circ}$ Ed. Editora Martins Fontes. São Paulo.

Vygotsky, L. S. (2011). A defectologia e o estudo do desenvolvimento e da educação da criança anormal. Educação e Pesquisa, 37(4), 863-869.

Vygotsky, L. S (2012a). Aprendizagem e desenvolvimento intelectual na idade escolar. In L.S. Vygotsky; S. R. Luria \& A.N. Leontiev, Linguagem, Desenvolvimento $e$ aprendizagem. (12 edição). São Paulo: Editora Ícone.

Vygotsky, L. S (2012b.) Thought and Language. (Ed. Alex Kozulin). Cambridge Press. Londres. Reino Unido.

Vygotsky, L. S. \& Luria, A. R. (1994). Tool and Symbol in child development. In. R. Van Der Veer \& J. Valsiner (Eds.), The Vygotsky reader (pp. 73-98). Cambridge, MA: Blackwell Publisher

Wallon, H. (1975). Psicologia e Educação na Infância. Lisboa: Editorial Estampa Wallon, H (2007). A evolução psicológica da criança. Tradução Claudia Berliner. Editora Martins Fontes. São Paulo.

Wallon, H. (1986). O papel do outro na consciência do Eu. In M. J. Werebe, \& J. NadelBrulfert (Orgs.), Henri Wallon (pp.158-167). São Paulo: Ática.

Wallon, H. (1995). As origens do caráter na criança. São Paulo: Nova Alexandria.

Wallon, H. (2007). A evolução psicológica da criança. São Paulo: Martins Fontes, 2007.

Wallon, H. (2008). Do ato ao pensamento: Ensaio de uma psicologia comparada. Rio de Janeiro: Editora Vozes

Warford, M. K. (2011). The zone of proximal teacher development. Teaching and teacher education. Vol.27.pp.252-258 
Wasserman, A. D. \& Mahowald, M. B. (1998). Disability, difference, discrimination. Lanham: Rowman and Littlefield.

Wertsch, J. V.; Rel Rio, P. \& Alvarez, A. (1995). Sociocultural studies: history actions and mediation. In: J. V. Wertsch; P. Rel Rio \& A. Alvarez. Sociocultural studies of mind. p. 1-36. Cambridge: Cambridge University Press.

Wood, D.; Bruner, J. \& Ross, G. (1976). The role of tutoring in problem solving. Journal of Child Psychology and Psychiatry and Allied Discipline, 17(2), 89-100.

Woodward, A. L. \& Sommerville J. A. (2000). Twelve-month-old infants interpret action in context. Psychological Science, 11(1), 73-77.

Woodward, A. L. (2009). Infants' grasp of others' intentions. Current directions in psychological science, 18(1), 53-57. Doi:10.1111/j. 1467-8721.2009.01605.x.

Yin, R. K. (2010). Estudo de caso: planejamento e métodos. Porto Alegre: Bookman. 


\section{Anexos}

Anexo A - Roteiro para entrevista com os familiares

1. Quem é para você? Me conte um pouco sobre como você vê seu filho hoje.

2. Você poderia me contar um pouco da história de vida da sua família e do ?

3. Como foi o período de gestação?

4. Como foi a descoberta da Síndrome de Down para você e para sua família? Como vocês reagiram com a notícia do diagnóstico?

5. Quando ___ nasceu, como foram os primeiros anos de vida? Você poderia me contar um pouco como foram os primeiros meses de vida dele?

6. Teve algum problema de saúde nesse início de vida? Como a família reagiu a isso?

7. Quem cuidou do ___ nesse início de vida? Como era a rotina dele?

8. Tinha alguma coisa que chamava sua atenção nesse começo de vida?

9. E depois, você se lembra como foram os primeiros anos de vida de

10. Como e quando ele aprendeu a andar?

11. O que ele gostava de comer?

12. Tinha problemas com alimentação? Sono?

13. Quem esteve mais próximo dele durante esse primeiro ano de vida?

14. Ele já frequentou escola antes dessa? Com quantos anos ele foi para escola? Como era esse ambiente escolar?

15. Durante o tempo que ele fica em casa hoje, como é a rotina dele?

16. Como que ele aprende as coisas?

17. Você já observou como é o processo de aprendizagem dele?

18. Do que ele gosta?

19. O que chama sua atenção?

20. Do que ele brinca normalmente?

21. Ele tem brinquedos preferidos? O que ele gosta de fazer?

22. Quem são as pessoas que mais gosta de estar por perto?

23. Por que você acha que ele se identifica com essas pessoas?

24. Ele tem amigos da idades dele nos espaços sociais que ele frequenta?

25. Como ele tem se comportado ao longo desses anos na presença de outras crianças?

26. O que você pensa sobre os momentos de interação do com outras crianças?

27. Quando você quer ensinar alguma coisa para ele como você faz?

28. Frente a tudo o que você me falou, de todas as coisas que você se lembrou nesse momento, quais são suas expectativas para ?

29. O que você espera dessa escola? O que você gostaria que acontecesse prioritariamente esse ano? 
Anexo B - Roteiro para entrevista com os professores

1. Você poderia me contar um pouco sobre sua história profissional? Quantos anos de profissão você tem? Por que escolheu a carreira docente? Quais são os aspectos mais importantes para você em ser professor(a)?

2. Você está hoje atuando diretamente com uma criança com déficit intelectual. Como você se sente em relação a isso? É a primeira vez que você atua com uma criança com necessidades educacionais especiais?

3. O que é déficit intelectual para você?

4. Como que você acha que essa criança aprende?

5. Quais são suas expectativas para a escolarização dessa criança?

6. Qual o seu papel nesse processo?

7. Como você tem pensado sobre a sua intervenção pedagógica junto a esse aluno?

8. É feito algum tipo de planejamento específico?

9. Teve alguma alteração na estruturação do espaço da sala de aula em decorrência da presença de ?

10. Quais são os elementos que você prioriza na sua prática pedagógica junto a seus alunos? E para o também seriam esses elementos?

11. Nesses primeiros dias em que você teve contato com , O que você poderia me dizer a respeito dessa criança?

12. Você identifica-o como uma criança com déficit intelectual?

13. A estrutura escolar oferece algum tipo de apoio a você neste processo?

14. Sobre a formação específica para atuar com alunos com déficit, você acha essa formação em educação especial relevante? Você tem algum tipo de formação específica? Qual?

15. No que essa formação poderia auxiliar no processo educativo? 